\author{
Universidade de São Paulo \\ Faculdade de Medicina de Ribeirão Preto \\ Departamento de Genética \\ Área de Pós-Graduação em Genética
}

\title{
O papel modulador do gene Aire (autoimmune regulator) sobre redes de expressão gênica em células tímicas epiteliais medulares.
}

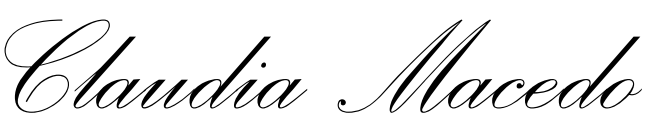

Ribeirão Preto

2008 


\section{Claudia Macedo}

\section{O papel modulador do gene Aire (autoimmune regulator) sobre redes de expressão gênica em células tímicas epiteliais medulares.}

Tese apresentada ao Programa de PósGraduação em Genética da Faculdade de Medicina de Ribeirão Preto da Universidade de São Paulo para obtenção do Título de Doutor em Ciências (Genética).

Orientador: Prof. Dr. Geraldo A. S. Passos

Ribeirão Preto 
Macedo, Claudia

O papel modulador do gene Aire (autoimmune regulator) sobre redes de expressão gênica em células tímicas epiteliais medulares.

Ribeirão Preto, 2008

289 p. $30 \mathrm{~cm}$

Tese de Doutorado apresentada à Faculdade de Medicina de Ribeirão

Preto, USP, Área de Concentração: Genética.

Orientador: Passos, Geraldo Aleixo da Silva
1. cDNA microarrays
2. MTEC
3. Sistema Imune 


\section{APOIO E SUPORTE FINANCEIRO}

Este trabalho foi realizado no laboratório de Imunogenética Molecular, localizado no Departamento de Genética da Faculdade de Medicina de Ribeirão Preto (FMRP) - USP com o apoio financeiro das seguintes entidades e instituições:

$\checkmark$ Conselho Nacional de Desenvolvimento Científico e Tecnológico (CNPq)

$\checkmark$ Fundação de Amparo à Pesquisa do Estado de São Paulo (FAPESP)

$\checkmark$ Fundação de Apoio ao Ensino, Pesquisa e Assistência do Hospital das Clínicas da FMRP - USP (FAEPA)

$\checkmark$ Faculdade de Medicina de Ribeirão Preto - FMRP - USP 
Dedico Especialmente este Trabalho

Meu marido, Leandio

Por todo o seu amor, respeito, cuidado, dedicação, incentivo e apoio em todos os momentos desta etapa da minha vida. Por compreender a ausência, principalmente na etapa final.

Obrigada por estar sempre ao meu lado!!!

Eu te amo muito!!! 
Ofereço Especialmente este Trabalho

À minha amada família

Meus pais, famile Sracy, por absolutamente tudo! Pelo amor incondicional, por todo incentivo e apoio durante a minha vida.

Por todo exemplo que vocês são para mim.

Minhas irmãs, Yanessa e Sha Paula, apoio e consolo.

Por terem tornado minha vida melhor. Companheiras de toda a minha existência.

Amo muito vocês!!! 


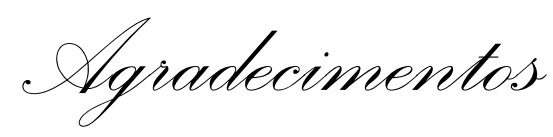

Agradeço do fundo do meu coração a todas as pessoas que de modo direto ou indireto participaram na realização deste trabalho.

Agradeço ao meu orientador, Prof. Dr. Geraldo Aleixo da Silva Passos, por seu exemplo de seriedade, profissionalismo e dedicação, por toda confiança e incentivo durante esses mais de 10 anos de envolvimento entre mim e a pesquisa.

Aos professores do Departamento de Genética, em especial às professoras Dra. Elza Tiemi Sakamoto-Hojo e Dra. Catarina Satie Takahashi, pela colaboração e amizade, que auxiliaram no andamento da pesquisa.

Ao Professor Dr. Eduardo A. Donadi pelo apoio ao longo do trabalho.

Aos pós-graduandos e funcionários do Departamento de Genética da Faculdade de Medicina de Ribeirão Preto (FMRP) por toda amizade e dedicação concedida nestes anos.

Às secretárias Maria Aparecida e Susie por todo carinho atenção.

Ao Departamento de Genética da Faculdade de Medicina de Ribeirão Preto, em particular, ao Laboratório de Imunogenética Molecular, onde foi realizado esse trabalho.

À todos os amigos do Grupo de Imunogenética Molecular com os quais convivi nos últimos dez anos, inclusive os que já partiram. Obrigada pelas alegrias, os ensinamentos, colaborações e pela convivência extremamente agradável que marcaram estes anos... Adoro vocês!!!!

Aos amigos do laboratório de Citogenética e Mutagênese, pelo carinho e disponibilidade todas as vezes que precisei utilizar o laboratório.

Ao laboratório TAGC INSERM de Marseille, França, onde realizei meu estágio de doutorado.

À minha família, inclusive minha sogra Silvana, por estarem sempre me apoiando e incentivando em todos os momentos.

Ao $\mathrm{CNPq}$, pelo auxílio concedido por meio de bolsa de doutorado (Processo 140380/2003-05), e estágio sanduíche no exterior (Processo 200992/2005-8). 


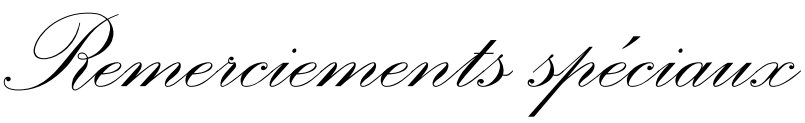

Moi même et mon directeur de thése, le Professeur Geraldo Passos, nous voudrions remercier vivement toute $l^{\prime}$ Équipe de recherche ‘ Technologies Avancées pour le Génome et la Clinique (TAGC) URM206 de l' Institut National de la Santé et la Recherche Médicale (INSERM) de Marseille, France, en particulier le Docteur Catherine Nguyen par l'accueil au sein de cette Équipe et pour l'orientation scientifique en ce qui concerne l'importance du thymus.

Je voudrais aussi remercier Beatrice Loriod, Nicolas Boulanger, Murielle Saade, Geneviève Victorero et Docteur Denis Puthier par toute aide et amitié accordées.

Finalement nous sommes très reconnaissants aux Instituitions brésiliennes et françaises suivantes; Université de São Paulo, FAPESP, CNPq, INSERM et Université de Marseille, Campus de Luminy.

Je vous en remercie !!!

Claudia Macedo 


\section{Índice}

RESUMO

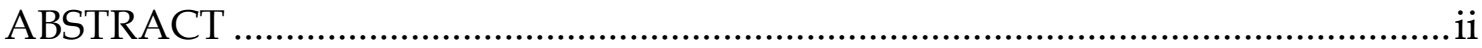

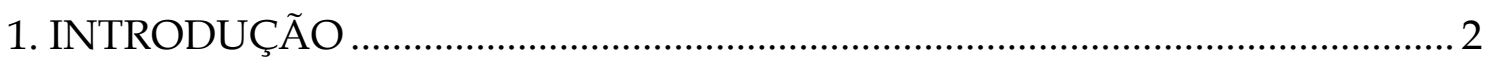

1.1. A maturação e o papel das células tímicas epiteliais medulares (mTECs) 2

1.1.1. Ontogenia do timo .................................................................................... 2

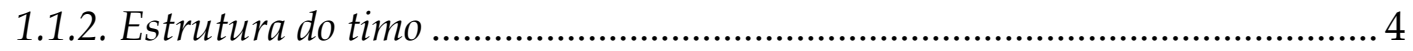

1.1.3. Migração das células precursoras linfóides para o timo ................................. 8

1.1.4. Maturação dos timócitos em células T ........................................................... 9

1.1.5. As células medulares epiteliais tímicas (mTECs)....................................... 14

1.2. Expressão gênica promíscua no timo e a indução de tolerância central... 18

1.3. O papel do gene Autoimmune regulator (Aire) ......................................... 23

1.4. Testando a hipótese da ação indireta do gene Aire: Construção de redes gênicas a partir de dados de microarrays .......................................................... 26

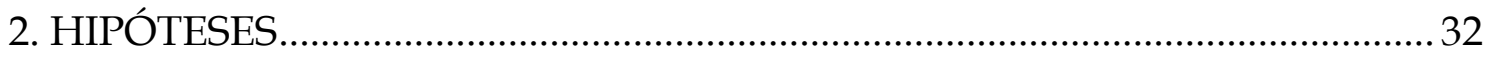

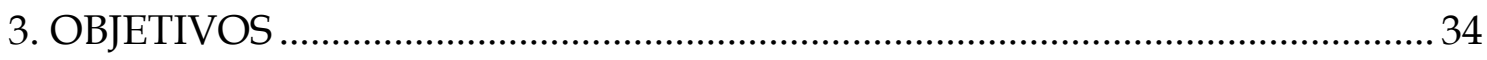

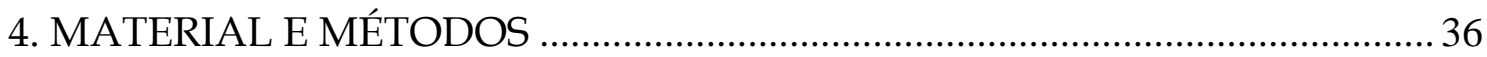

4.1. Linhagem celular mTEC 3.10 (células tímicas epiteliais medulares) ........ 36

4.2. Inibição seletiva do transcrito do gene Aire com RNA interferente

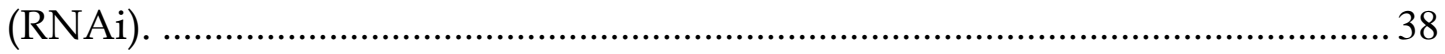

4.2.1. Determinação da seqüência de RNAi anti-Aire. .......................................... 38

4.2.2. Silenciamento do transcrito do gene Aire em cultura de células mTEC 3.10. .. 40

4.3. Extração de RNA total........................................................................................ 41

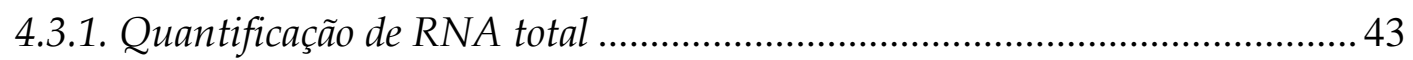

4.4. Eletroforese de RNA total em gel denaturante (Sambrook et al., 1989) ... 44

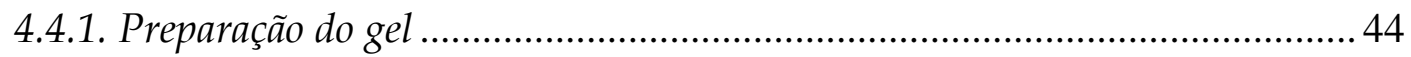

4.4.2. Preparação das amostras de RNA.............................................................. 44

4.5. PCRs semi-quantitativas para os genes Aire e HPRT. ................................ 45

4.6. Preparação de cDNA microarrays em lâminas de vidro ............................. 45

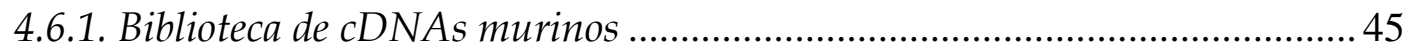

4.6.2. Amplificação de cDNA para a confecção de microarrays .............................. 46

4.6.3. Purificação dos produtos de PCR .............................................................. 47

4.6.4. Confecção das lâminas de microarrays ......................................................... 48

4.7. Delineamento das hibridações em microarrays .......................................... 49

4.8. Marcação das sondas complexas de cDNA com fluorocromos CY3 e CY5 .............. 52 
4.9. Hibridação das lâminas de microarrays ......................................................... 58

4.10. Aquisição de imagens de microarrays ....................................................... 58

4.11. Quantificação e normalização dos dados de microarrays ......................... 59

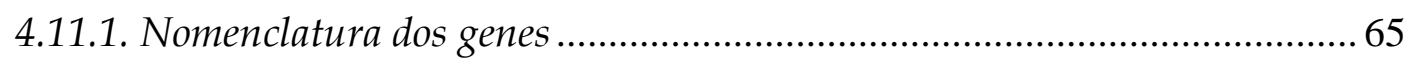

4.12. Análise da expressão gênica promíscua ....................................................... 65

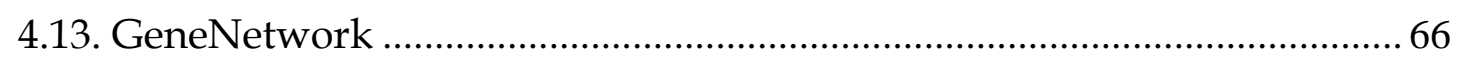

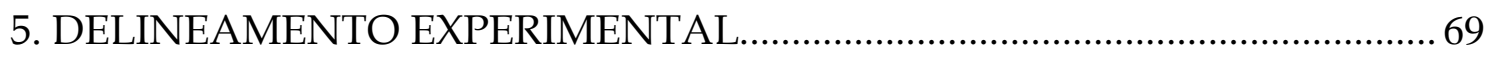

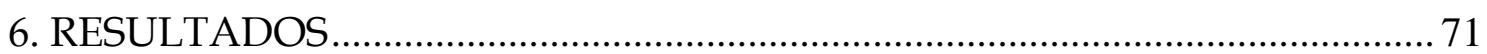

6.1. Inibição seletiva do transcrito do gene Aire com RNA interferente (RNAi). ....................................................................................................... 71

6.1.1. Monitoramento da transfecção e determinação da seqüência de RNAi anti-

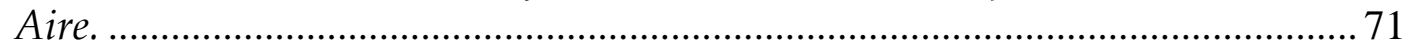

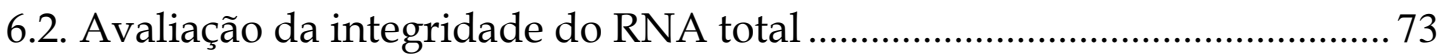

6.2.1. Amostras utilizadas como "pool" de referência .............................................. 73

6.2.2. RNA total de Amostras de células mTEC. .................................................. 74

6.3. RT-PCRs semi-quantitativas para os transcritos dos genes Aire e HPRT.75

6.4. Amplificação de cDNA para a confecção de microarrays ........................... 76

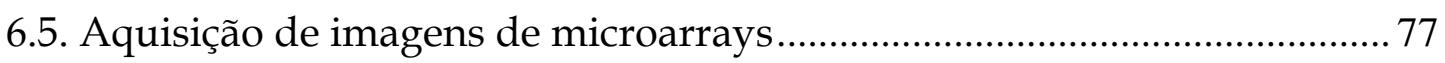

6.6. Quantificação e normalização dos dados de microarrays .......................... 79

6.7. Análise da expressão gênica promíscua....................................................... 84

6.8. Influência do silenciamento do transcrito do gene Aire sobre as redes de interações gênicas das células mTEC ....................................................................... 87

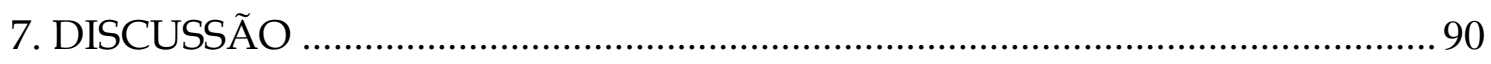

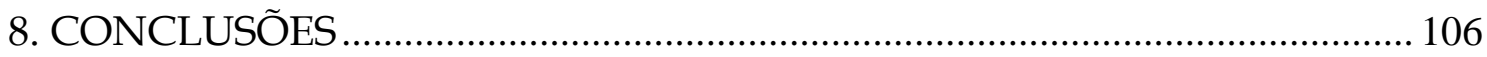

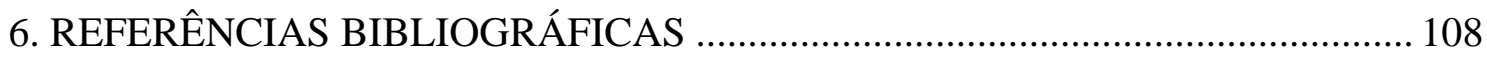

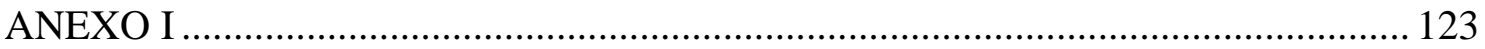

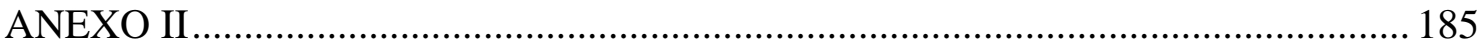

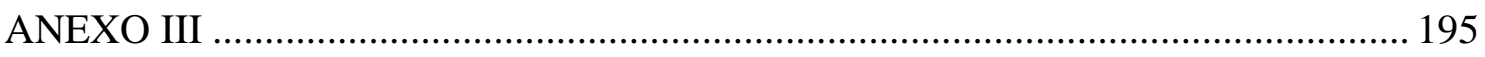

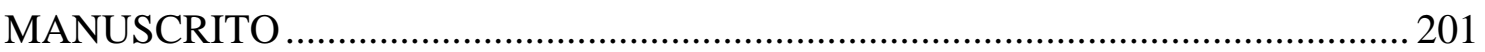

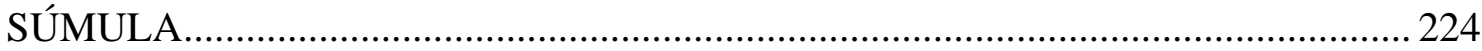

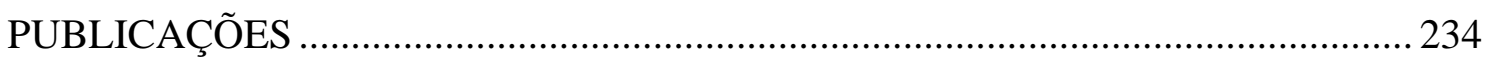




\section{INDICE DE FIGURAS}

Figura 1. Desenvolvimento do microambiente epitelial do timo.......................... 5

Figura 2. Esquema representativo da estrutura do timo e de todos os seus

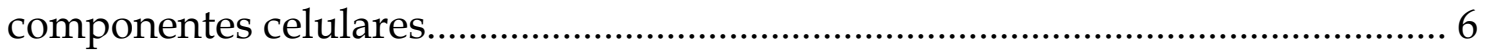

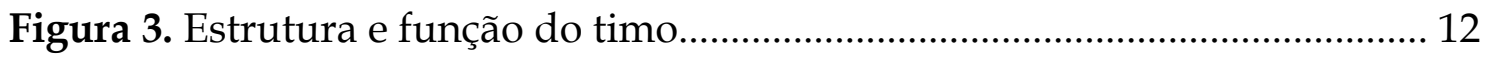

Figura 4. Diferenciação das células epiteliais tímicas.......................................... 16

Figura 5. Representação de diversos tecidos e órgãos parenquimais no timo

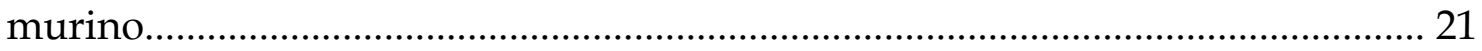

Figura 6. Padrão de expressão de CD80 em mTEC 3.10 ...................................... 37

Figura 7. Esquema dos principais tipos de delineamento experimental para

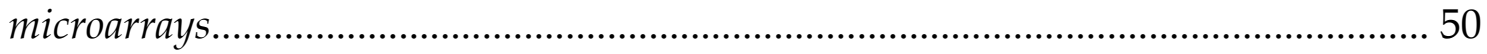

Figura 8. Preparação da fita simples de cDNA incorporada com amino alil..... 53

Figura 9. Preparação do cDNA marcado com CyDye ......................................... 54

Figura 10. "Pipeline" utilizado na análise de dados de microarrays em lâminas de

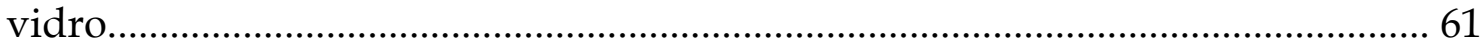

Figura 11: Comparação entre a distância relativa observada d(i) e esperada

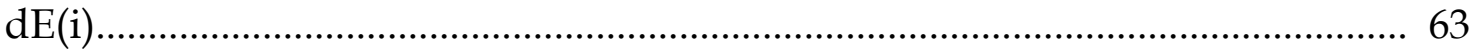

Figura 12. Fluxograma do trabalho mostrando o sistema modelo experimental utilizando células tímicas epiteliais medulares (mTEC 3.10). 69

Figura 13. Células mTEC 3.10 após 24 h em cultura em presença de RNAi

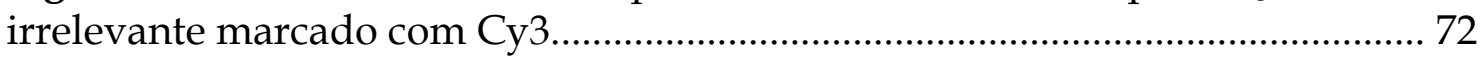

Figura 14. Sequência do RNA interferente para o transcrito do gene Aire........ 72

Figura 15. Eletroforese em gel de agarose de produtos de rt-PCR semiquantitativa para a detecção do transcrito do gene Aire................................ 73

Figura 16. Eletroforese em gel de agarose de seis amostras de RNA total provenientes de timos de camundongos C57Bl/ 6 adultos................................ 74

Figura 17. Eletroforese em gel de agarose de amostras de RNA total

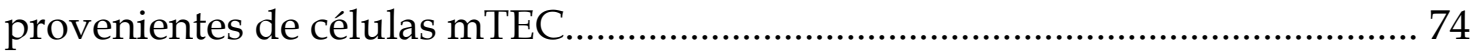

Figura 18. Eletroforese de produtos de rt-PCR semiquantitativa para o gene HPRT.

Figura 19. Eletroforese de produtos de rt-PCR semiquantitativa para o gene Aire.

Figura 20. Eficiência das amplificações por PCR dos clones de cDNA IMAGE utilizados no preparo do microarray. 
Figura 21. Eletroforese em gel de agarose $1 \%$ dos produtos de PCR de alguns clones da biblioteca de cDNA IMAGE.

Figura 22. Imagem típica de hibridização de microarray com sondas fluorescentes (Cy3 e Cy5). 78

Figura 23. Agrupamento hierárquico mostrando o perfil de expressão gênica dos diferentes grupos de células mTEC.

Figura 24. Genes diferencialmente expressos em células mTEC 42 horas após a inibição do transcrito do gene Aire.

Figura 25. Agrupamento hierárquico mostrando o perfil de expressão gênica de células mTEC transfectadas com RNAi anti-Aire. 83

Figura 26. Gráfico ilustrativo gerado pelo banco de dados Symatlas. 85

Figura 27. Representação da expressão gênica específica de tecidos e órgãos em células mTEC. Os genes significativamente induzidos em células mTEC transfectadas. 86

Figura 28. Representação da expressão gênica específica de tecidos e órgãos em células mTEC. Os genes significativamente reprimidos em células mTEC transfectadas

Figura 29. Rede de interações gênicas de células medulares epiteliais tímicas (mTEC linhagem 3.10) cultivadas sob condições controle. 88

Figura 30. Rede de interações gênicas de células medulares epiteliais tímicas (mTEC linhagem 3.10) transfectadas com RNAi anti-Aire 


\section{INDICE DE TABELAS}

Tabela I. Oligonucleotídeos primers utilizados nas reações de RT-PCR

Tabela II. Genes diferencialmente expressos comparando-se os cinco grupos de células analisadas

Tabela III. Genes diferencialmente expressos comparando-se células mTEC controles versus células mTEC transfectadas com RNAi anti-Aire

Tabela IV. Genes da rede controle que fazem interação com o nó gênico Gucy2d e o tipo de interação.

Tabela V. Genes da rede experimental que fazem interação com o nó gênico Gucy2d e o tipo de interação 


\section{RESUMO}

A expressão de antígenos restritos a tecidos (TRAs do inglês tissue restricted antigens) no timo pelas células epiteliais medulares (mTECs de medullary thymic epithelial cells) é essencial para a tolerância central das células T.

Devido à sua heterogeneidade em termos de representação de autoantígenos, esse fenômeno foi denominado como expressão gênica promíscua (PGE de promiscuous gene expression), no qual o gene Aire (de autoimmune regulator) desempenha um papel como principal regulador transcricional positivo sobre um grande conjunto de TRAs dependentes de Aire.

A proteína Aire tem a capacidade de interagir com seqüências específicas de DNA desempenhando um papel como regulador direto.

Neste estudo utilizamos o método dos cDNA microarrays para acessar a PGE em células mTEC CD80+ murinas cultivadas in vitro. $\mathrm{O}$ agrupamento hierárquico dos dados permitiu a observação de que os genes de TRAs foram diferencialmente expressos. Para testar essa hipótese, inicialmente silenciamos o gene Aire pelo método de RNA interferente (RNAi) nas células mTEC.

O agrupamento hierárquico dos dados de cDNA microarray mostrou um conjunto de genes de TRAs dependentes de Aire, os quais foram reprimidos após o silenciamento deste último. Redes gênicas reconstruídas desses dados permitiram a identificação de um nó gênico (Gucy2d) estabelecendo regulação positiva sobre genes downstream nas células mTEC normais. Entretanto, sob efeito do silenciamento de Aire, Gucy2d passou a ser um repressor.

Esses resultados evidenciaram que genes da PGE estão conectados em rede, que um nó gênico pode atuar como intermediário no seu controle e que Aire na rede PGE desempenha seu controle como regulador upstream. 


\title{
Promiscuous gene expression in medullary thymic epithelial cells is connected in network where the Aire gene is an upstream modulator
}

\begin{abstract}
The expression of tissue restricted antigens (TRAs) in thymus by medullary thymic epithelial cells (mTECs) is essential for the central selftolerance of $\mathrm{T}$ cells.

Due to heterogeneity of autoantigen representation this phenomenon has been termed promiscuous gene expression (PGE), in which the autoimmune regulator (Aire) gene plays a role as main positive transcriptional regulator on a large set of Aire-dependent TRAs.

Aire protein is able in binding to specific DNA sequence motifs and plays a role as a direct regulator.

Here we used the cDNA microarray method to access PGE in murine $\mathrm{CD}^{+} 0^{+}$mTECs cultured in vitro. Hierarchical clustering of the data allowed observation that TRA genes were differentially expressed. To further investigate the control of PGE, we hypothesize that TRA genes establish networks contributing it selves to modulate their transcriptional levels. Aire in this case plays a role as upstream positive modulator. To test this hypothesis, initially we silenced Aire by gene knockdown (RNA interference) in mTECs.

Hierarchical clustering of cDNA microarray data showed a set of Airedependent TRAs genes, which were down regulated after Aire silencing. Gene networks reconstructed from these data allowed the identification of a gene node (Gucy2d) establishing positive regulation upon downstream genes in normal mTECs. Nevertheless, under silencing of Aire, Gucy2d has become a repressor.
\end{abstract}

These finding evidentiate that, genes features in PGE are connected in network; a gene node may act as intermediate in their control and that Aire in PGE network plays a role as an upstream regulator. 
Introducão 


\section{INTRODUÇÃO}

\subsection{A maturação e o papel das células tímicas epiteliais medulares (mTECs)}

\subsubsection{Ontogenia do timo}

A origem do desenvolvimento do epitélio do timo tem sido debatida por décadas. Inicialmente, Cordier \& Haumont (1980) sugeriram que o compartimento epitelial do timo seria derivado da ectoderme (córtex) e da endoderme (medula).

A hipótese de "origem dual" baseia-se na formação de um rudimento tímico de natureza reticuloepitelial e outro de origem endoectodérmica derivadas da terceira bolsa faríngeana e fenda branquial. $\mathrm{O}$ retículo do epitélio medular tímico é de origem endodérmica, enquanto que o retículo do epitélio cortical tímico é de origem ectodérmica. Nesta bolsa se formam tubos de células epiteliais que vão crescendo em forma de cordões para baixo até o tórax. Os cordões perdem a comunicação com sua origem e se transformam na medula do timo. Durante sua migração, decorrente de sua aderência ao pericárdio visceral, o rudimento tímico é invadido por vasos sanguíneos que serão os portadores dos precursores de timócitos, células dendríticas, macrófagos e mastócitos. As células reticulares epiteliais emitem prolongamentos e formam os septos, corpúsculos de Hassal e as áreas onde vão ser ocupadas pelos linfócitos T em maturação no córtex. Posteriormente, inicia-se a tração pelo pericárdio, que leva o timo até sua posição anatômica no mediastino anterior na maioria dos animais, sendo que o timo se mantém no 
extramediastino cervical nas aves e branquial nos peixes (van Ewijk et al., 2000; Gray et al., 2005).

Embora num primeiro momento estudos digam que o timo tenha se derivado das células epiteliais de ambas as origens endodérmica e ectodérmica, experimentos em aves e camundongos, via transplante ectópico, tem demonstrado conclusivamente que as células epiteliais tímicas são exclusivamente de origem endodérmica, deste modo, refutando o modelo de "origem dual" de ontogenia epitelial tímica e aceitando um novo modelo de "origem única" (Anderson \& Jenkinson, 2001; Blackburn \& Manley, 2004; Barthlott et al., 2006).

Recentemente, análises clonais utilizando embriões com 12 dias de desenvolvimento (Rossi et al., 2006) e experimentos com mapeamentos indicando um progenitor comum para as células corticais e medulares (Bleul et al., 2006), têm conclusivamente mostrado que somente um folheto germinativo contribui para o compartimento epitelial tímico e esse folheto seria a endoderme. Contudo, não se podem excluir sinais de indução e/ou sobrevivência de outro folheto germinativo (Manley et al., 2003; Gordon et al., 2004; Boehm \& Bleul, 2006).

Em camundongos, o timo surge como estruturas bilaterais da terceira bolsa faringeana no intestino primário embrionário (Manley, 2000; Gordon et al., 2001) e são colonizados por progenitores hematopoéticos por volta do 11.5 dia do desenvolvimento embrionário (Itoi et al., 2001). O primeiro marcador descrito para essa região foi o Foxn1, necessário para o desenvolvimento de células epiteliais tímicas funcionais, para a formação do timo e, portanto, para a formação da diversidade do repertório de células T auto-tolerantes (Nehls et al., 1996; Boehm et al., 2003; Bleul et al., 2006). 
Recentemente surgiram evidências da presença de um segundo timo em algumas linhagens de camundongos, chamado cervical, que se desenvolve após o nascimento e tendo o mesmo tamanho de um linfonodo. As células epiteliais no timo cervical também expressam Foxn1, indicando sua relação com o compartimento epitelial do timo toráxico (Dooley et al., 2006; Terszowski et al., 2006). Essa descoberta pode mudar todo nosso conhecimento a cerca deste órgão, porém muitos estudos ainda deverão ser realizados a fim de se chegar a conclusões definitivas.

A involução alométrica do timo inicia-se pouco antes do nascimento e a involução absoluta ocorre na puberdade, entretanto o timo adulto continua a receber células precursoras, vindas da medula óssea e a lançar células colonizadoras das áreas T periféricas (Bodey et al., 1997). Esse fenômeno é conhecido e frequentemente associado à idade, sendo caracterizado pela substituição do estroma tímico por tecido adiposo (Montecino-Rodriquez et al., 2005).

\subsubsection{Estrutura do timo}

O timo é um órgão linfóide primário em que os precursores de células $\mathrm{T}$ derivados da medula óssea se submetem a um processo complexo de maturação no contexto do microambiente tímico, representado por células não linfóides e linfóides e por componentes da matriz extracelular (ECM) (Villa-Verde et al., 1995). É formado por dois lobos (direito e esquerdo), sendo ambos divididos em múltiplos lóbulos por septos fibrosos. Anatomicamente, cada lóbulo é dividido em uma região subcapsular, um córtex, que contém uma densa coleção de linfócitos $\mathrm{T}$ em maturação e uma medula, com uma população mais 
esparsa de linfócitos (tecido conjuntivo frouxo e células reticulares epiteliais), e onde ocorrem os processos finais de maturação dos linfócitos T (Abbas \& Lichtman, 2005; Boehm \& Bleul, 2006) (Figura 1).

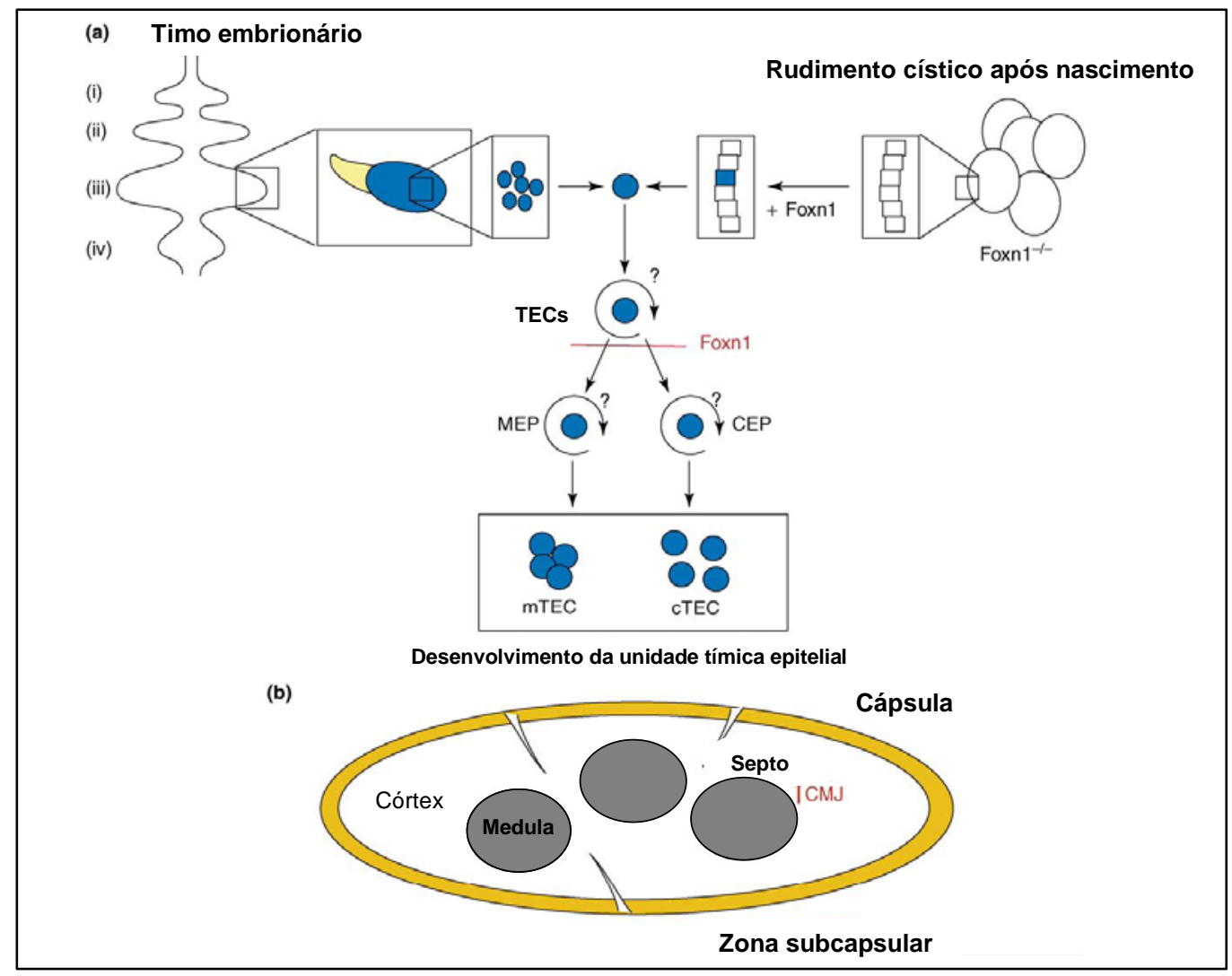

Figura 1. Desenvolvimento do microambiente epitelial do timo. A) Capacidade de desenvolvimento das células TEC progenitoras. Á esquerda estão indicadas as quatro bolsas faringeanas (i-iv); a origem comum da paratireóide (amarelo) e do timo (azul) está situada na terceira bolsa faringeal. À direita, as células supridas com o gene funcional Foxn1 apresentam timopoiese normal. Ao centro, um modelo para a diferenciação das células epiteliais do timo. Se existe ou não progenitoras epiteliais bipotentes para células medulares (MEP) e/ou corticais (CEP) não é sabido. B) Estrutura de um timo adulto encapsulado e dividido pelos septos mesenquimais em lóbulos individuais. $\mathrm{CMJ}=$ junção córtico-medular (cortico-medullary junction) (Extraído e modificado de Boehm \& Bleul, 2006)

O córtex proporciona um microambiente necessário para a seleção positiva dos timócitos imaturos enquanto que a medula é responsável pela seleção negativa das células $\mathrm{T}$ auto-reativas. Os progenitores linfóides entram no timo adulto pela junção córtico-medular e então 
migram para a região subcapsular antes, porém, retornando pelo córtex em direção a medula (Anderson \& Jenkinson, 2001).

Cada um destes compartimentos forma um microambiente estromal especializado que é crucial para controlar a maturação das células T. Este estroma é composto essencialmente de células epiteliais corticais (cTECs) e medulares (mTECs), fibroblastos reticulares, células dendríticas e macrófagos derivados da medula óssea, além de estruturas conhecidas como corpúsculos de Hassal, localizados especificamente na medula tímica e composto de espirais compactas de células epiteliais remanescentes de células em degeneração (Figura 2).O timo tem um suprimento vascular abundante e vasos linfáticos eferentes que drenam para os linfonodos do mediastino (Abbas \& Lichtman 2005).

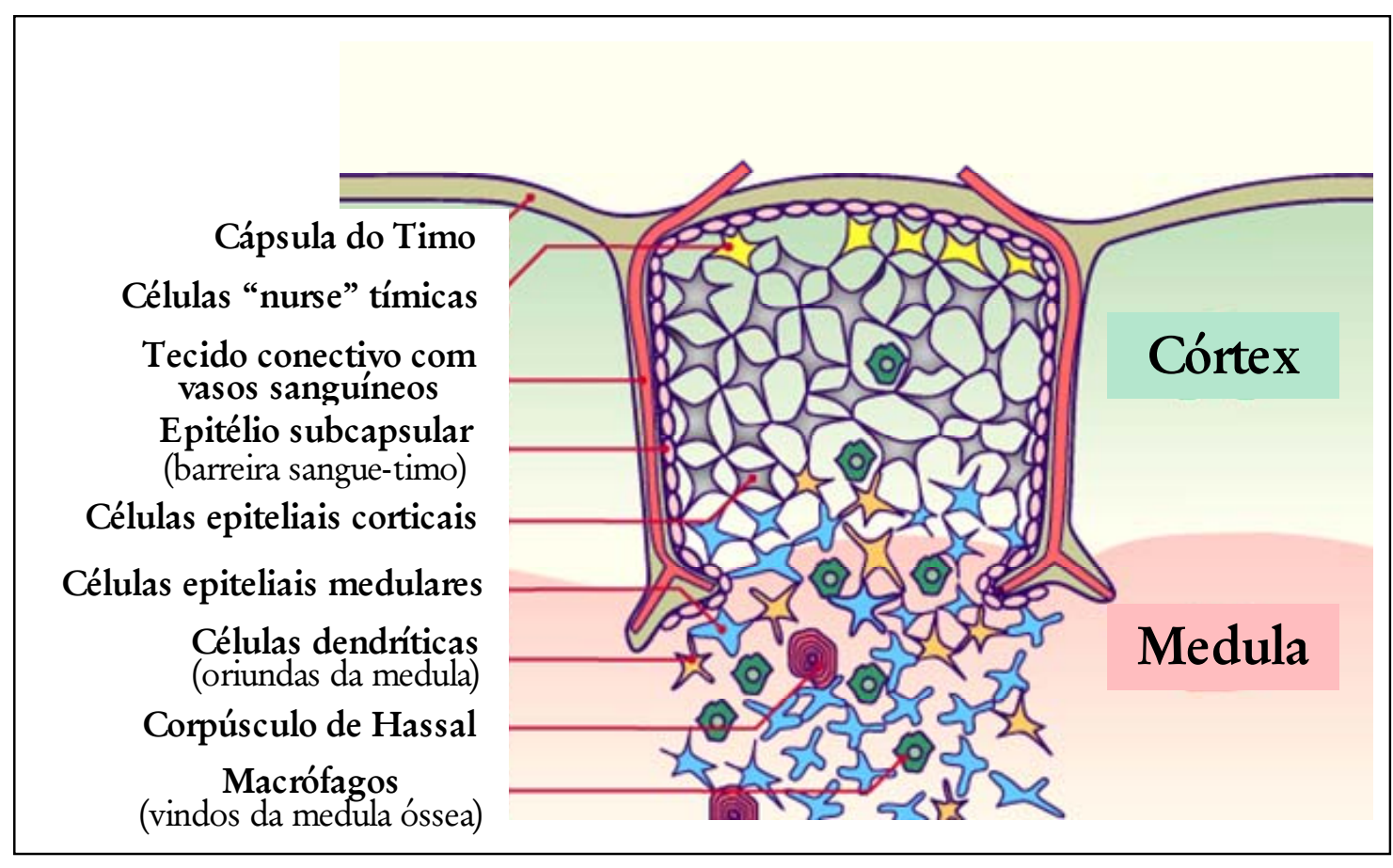

Figura 2. Esquema representativo da estrutura do timo e de todos os seus componentes celulares. (Extraído e modificado de Human Embriology http:/ / www.embryology.ch/anglais/qblood/lymphat03.html).

A manutenção do microambiente tímico requer interações recíprocas entre timócitos e células estromais, denominadas de "cross 
talk" tímico (van Ewijk et al., 1994; van Ewijk et al., 2000; Germeraard et al., 2003; Gray et al., 2006).

A interação dos precursores de timócitos com o microambiente estromal permite o comprometimento desses com as linhagens celulares $\mathrm{T}$ e essencialmente elimina ou permite a supressão de células autoreativas (Boehm \& Bleul, 2006; Anderson et al., 2007).

As células epiteliais tímicas são os componentes celulares principais do microambiente tímico, e influenciam diferentes aspectos da diferenciação dos timócitos, vias de interações célula-célula e das secreções de fatores solúveis, tais como os hormônios tímicos timulina (thymulin), timopoetina (thymopoietin) e timosina- a1 (thymosin-a1) (Savino, 2006).

Diversas moléculas foram identificadas que são importantes no desenvolvimento inicial do timo, incluindo forkhead box N1 (FOXN1), Tbox 1 (TBX1) e pre-B-cell leukaemia transcription factor 1 (PBX1) (Boehm \& Bleul, 2006)

Dados recentes mostram que o hormônio do crescimento (GH) modula pleiotropicamente funções tímicas como, por exemplo, aumenta a proliferação de timócitos e de células epiteliais tímicas (Savino, 2007).

Um complexo linfoepitelial localizado corticalmente no timo, as células "nurse" tímicas (TNC), são estruturas multicelulares linfoepiteliais formadas por uma célula epitelial tímica (TEC) que abriga 20-200 timócitos, carregando primeiramente o fenótipo duplo-positivo CD4/CD8, embora timócitos imaturos duplo negativos, bem como, células maduras simples positivas também possam ser encontradas. TNCs criam provavelmente um microambiente especial para a diferenciação e/ou proliferação dos timócitos, com timócitos sendo 
expostos aos antígenos do complexo principal de histocompatibilidade (MHC) e aos hormônios tímicos. Tal diferenciação ocorre em paralelo com a migração da célula dentro e fora do complexo (Savino, 2006).

O mesênquima tímico, derivado da crista neural, também pode ser capaz de influenciar diretamente o desenvolvimento dos precursores de células T CD4-CD8- por apresentação de fatores de crescimento solúveis sobre componentes da matriz extracelular (ECM). Além de influenciar o desenvolvimento das células epiteliais tímicas imaturas, e assim ter um papel direto no estabelecimento do microambiente tímico (Jenkinson et al., 2003).

\subsubsection{Migração das células precursoras linfóides para o timo}

Os precursores de células $\mathrm{T}$, ou células imaturas da linhagem de células $T$, derivados da medula óssea entram no timo na junção corticomedular, e então migram à região subcapsular da glândula através dos vasos sanguíneos. O desenvolvimento começa no córtex e, conforme os timócitos vão evoluindo eles migram para a medula tímica, de forma que esta contém principalmente células T maduras. Desta por sua vez, deixam o timo e entram no sangue e nos tecidos linfóides periféricos. As quimiocinas são uma grande família de citocinas estruturalmente homólogas que regulam a migração de linfócitos e outros leucócitos através dos tecidos linfóides periféricos (Blackburn \& Manley, 2004; Abbas \& Lichtman 2005).

As células do microambiente tímico produzem dois grupos de moléculas, as quimiocinas, incluindo Cxcl12 (Chemokine C-X-C motif ligand 12), a qual preferencialmente atrai timócitos imaturos CD4-CD8- e 
$\mathrm{CD}^{+} \mathrm{CD}^{+}$, e Ccl21 (Chemokine C-C ligand 21), que exerce quimioatração para timócitos simples positivos maduros, e as proteínas da matriz extracelular, visto que os timócitos em desenvolvimento expressam os receptores correspondentes. Além disso, embora as quimiocinas e a matriz extracelular possam dirigir a migração dos timócitos por si mesmo, uma função combinada para estas moléculas parece contribuir para os padrões de migração resultantes dos timócitos em seus vários estágios de diferenciação (Savino et al., 2003; Savino et al., 2006).

\subsubsection{Maturação dos timócitos em células T}

O processo de maturação dos linfócitos consiste numa complexa seqüência de eventos biológicos, compreendendo a proliferação das linhagens celulares precursoras, a expressão diferencial de proteínas de membrana, rearranjos gênicos do receptor de antígeno, a seleção do repertório de linfócitos maduros, e conseqüente morte celular programada dos linfócitos não selecionados e finalmente a migração celular. Durante cada um desses estágios, as células sofrem significativas mudanças celulares e genéticas (Abbas \& Lichtman, 2005).

A análise do desenvolvimento da célula $\mathrm{T}$ no timo conduziu à identificação de uma série de checkpoints durante o desenvolvimento inicial do timócito. Durante os estágios mais adiantados do desenvolvimento da célula $T$, a seleção positiva e negativa de timócitos $\mathrm{CD} 4+\mathrm{CD} 8+$, que conduz à produção de um repertório de células $\mathrm{T}$ tolerantes ao próprio, é da importância crítica em evitar respostas não desejadas da célula $\mathrm{T}$ aos antígenos próprios que podem se manifestar como auto-imunidade (Anderson et al., 2007). 
A maturação inicial caracteriza-se por um aumento da produção de todas as células sanguíneas na medula óssea e por uma alta atividade mitótica, estimulada principalmente pela interleucina 7 (IL-7) que é produzida pelas células do estroma da medula óssea e do timo e pelos ligantes Notch (Harman et al., 2005; Zamisch et al., 2005). A atividade proliferativa cessa depois que os genes para os receptores de antígeno são expressos. Tais genes surgem por um processo de recombinação somática gerando diversidade do repertório dos linfócitos após junção de segmentos gênicos diferentes.

A interação entre células estromais e linfóides dentro do microambiente tímico é um fator crítico para formar a correta especificidade antigênica do repertório de células $T$, assim como para capacitá-lo a responder à apresentação de antígenos estranhos pelas moléculas de MHC e não responder a antígenos próprios (Barthlott et al., 2006).

Os mecanismos que regulam o desenvolvimento e a seleção de células $\mathrm{T}$ expressando TCR- $\alpha \beta$ são governados por sinais de células estromais tímicas. Isto é ilustrado por estudos das linhagens de camundongo onde as mutações genéticas que afetam o desenvolvimento ou a função da célula estromal têm um efeito dramático na imunocompetência da célula T. Fenotipicamente as subpopulações distintas de timócitos ocupam áreas específicas dentro do timo, sugerindo que as células estromais dão forma aos microambientes especializados dentro do timo que compartimentaliza o desenvolvimento de timócitos e suportam estágios distintos do desenvolvimento da célula $\mathrm{T}$ (Anderson $e t$ al., 2007). Por exemplo, a zona subcapsular fornece um ambiente para os precursores duplo-negativos da célula T CD4-CD8-CD44-CD25+ e a seleção mediada pelo pré-TCR (Lind et al., 2001), o córtex tímico contém 
os timócitos duplo-positivos CD4+CD8+ que são sujeitos aos eventos de seleção da célula $\mathrm{T}$, enquanto que na medula tímica, células $\mathrm{T}$ simplespositivas $\mathrm{CD} 4+$ e CD8+ são selecionadas quanto à reatividade ao próprio antes de sua saída do timo (Takahama, 2006).

Os timócitos imaturos corticais recém-chegados ao timo contêm os genes de TRs na configuração germinativa e, portanto, ainda não expressam o TCR, CD3, as cadeias $\zeta$ e os co-receptores CD4 e CD8. Essas células são chamadas de timócitos duplo-negativos (DN) e se submetem à múltiplos ciclos de proliferação e de progresso ao estágio duplo-negativo CD4-CD8- (DN), aproximadamente 5\% do total de timócitos, com discretos passos de maturação distinguidos pela expressão de marcadores de superfície celular CD44highCD25- (DN1), CD44highCD25+ (DN2), CD44low CD25+ (DN3), e CD44lowCD25- (DN4). As proteínas do complexo recombinase (Rag-1 e Rag-2) são expressas pela primeira vez nesse estágio, e os rearranjos V(D)J se iniciam. Durante a transição da fase DN para duplo-positiva $\mathrm{CD}^{+} \mathrm{CD}^{+}(\mathrm{DP})$, aproximadamente $85 \%$ dos timócitos se redistribuem à região cortical (Ramialison et al., 2002). O rearranjo dos genes da cadeia a e a expressão do heterodímero TCR a $\beta$ ocorrem na população $\mathrm{CD}^{+}{ }^{+} \mathrm{CD} 8^{+}$, exatamente antes ou durante a migração dos timócitos do córtex para a medula (Figura 3). 


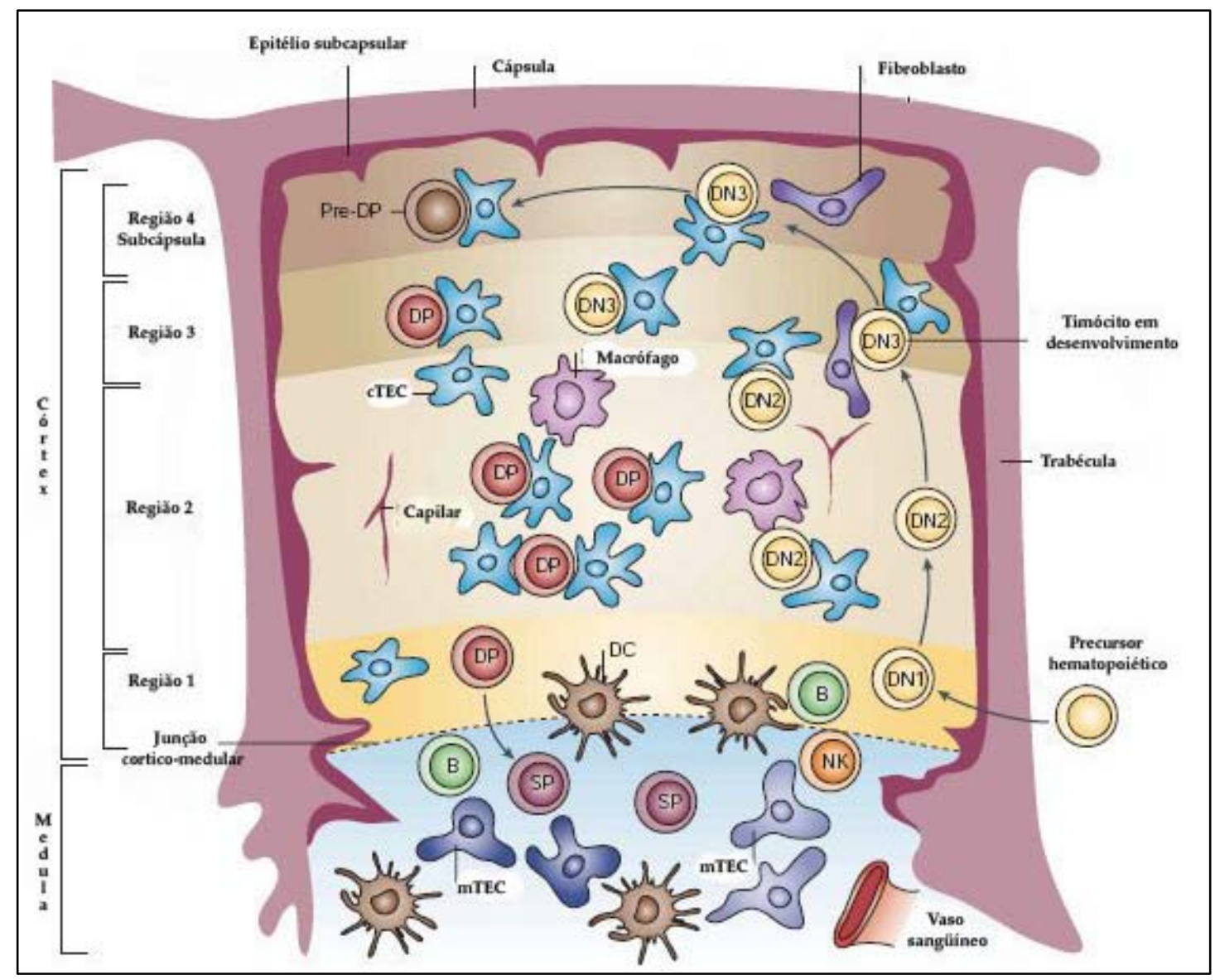

Figura 3. Estrutura e função do timo. Dividido em duas regiões, córtex e medula, povoados por diferentes subtipos celulares epiteliais tímicos (TECs). Nos adultos, os precursores de células $\mathrm{T}$ entram no timo pela junção cortico-medular, e começam então um programa altamente complexo de diferenciação, o qual está ligado à migração através do estroma tímico. Os subtipos diferentes de timócitos são encontrados conseqüentemente em regiões espacialmente restritas do timo. O córtex tímico foi separado em quatro regiões: Região 1, junção cortico-medular, local de entrada dos precursores de células T; Região 2, células diferenciadas em DN2 as quais se submetem a expansão clonal proliferativa; Região 3, inicia-se os rearranjos $V(D) J$ dos genes TRs em células no estágio DN3; Região 4, transição de DN para o estado de DP (CD4+CD8+). Células DP migram do córtex para a medula tímica, onde se diferenciam em simples positivas (SP CD4+ ou CD8+). A seleção positiva ocorre no córtex entre as TECs corticais (cTECs), e a seleção negativa ocorre principalmente na medula, entre as TECs medulares (mTECs) e células dendríticas (DCs). Células SP que completaram o programa de diferenciação saem da medula tímica em direção a periferia. [Extraído e modificado de Blackburn \& Manley, 2004].

A recombinação $\mathrm{V}(\mathrm{D}) \mathrm{J}$ dos receptores de células $\mathrm{T}$ é um evento molecular essencial na maturação destas células. É um processo de recombinação sítio específico da molécula de DNA que só ocorre nos estágios inicias de desenvolvimento dos linfócitos T e B. A geração de 
grande diversidade nas regiões variáveis do receptor de antígeno de linfócitos $\mathrm{T}$ é crucial para que os organismos possam reconhecer e responder contra, virtualmente, todo e qualquer antígeno estranho.

Cada locus TCR consiste de segmentos gênicos de regiões variáveis $(\mathrm{V})$, joinig $(\mathrm{J})$ e constante $(\mathrm{C})$, e para as cadeias $\beta$ e $\delta$ incluem segmentos gênicos de diversidade (D). De modo geral, o rearranjo dos segmentos gênicos, ocorre através da ligação de um segmento J a um dos segmentos $\mathrm{D}$, formando uma união D-J, posteriormente um dos segmentos gênicos $\mathrm{V}$ se liga ao segmento D-J unidos. Toda seqüência de DNA interveniente aos segmentos gênicos que se ligaram passam por um processo de deleção (Paul, 1993). Os segmentos gênicos rearranjados são transcritos em um RNA primário, que se torna um RNA maduro após o seu processamento. $\mathrm{O}$ rearranjo D-J e V-DJ ocorre entre os segmentos gênicos da cadeia $\beta$ e $\delta$ de TCR; entre os segmentos gênicos da cadeia $\alpha$ e $\gamma$ onde não há segmentos $D$, ocorre apenas o rearranjo V-J (Abbas \& Lichtman, 2005).

As primeiras células que expressam os TCRs estão no córtex tímico, e essa expressão é baixa em comparação com a célula T madura. Em virtude da expressão de seus complexos TCR completos, as células duplo-positivas podem responder ao antígeno e ficam sujeitas à seleção positiva e negativa. A maioria das células DP, as quais constituem cerca de $80 \%$ daquela população, morre por negligência porque não reconhecem moléculas disponíveis de MHC expressas por células estromais tímicas (Abbas \& Lichtman, 2005; Savino, 2006).

As células que passam com sucesso pelos processos de seleção amadurecem em células T CD4+ ou CD8+ e são chamadas de timócitos simples positivos (SP), e compreendem aproximadamente $10 \%$ dos timócitos no timo (Ramialison et al., 2002). Assim, os estágios de maturação das células T podem ser rapidamente distinguidos pela análise da expressão 
das moléculas CD4 e CD8. Essa maturação fenotípica é acompanhada da maturação funcional (Abbas \& Lichtman, 2005).

Finalmente, os timócitos maduros com positividade única (células T CD4 e CD8 restritas ao MHC) entram na medula do timo e deixam esse órgão pelos vasos sanguíneos para colonizar os tecidos linfóides periféricos (Haks et al., 1998). Apenas 15\% dos timócitos que vivem no timo nesta fase vão formar a maioria do repertório de células $\mathrm{T}$ periféricas (Savino, 2006).

\subsubsection{As células medulares epiteliais tímicas (mTECs).}

Os dois subconjuntos principais de células epiteliais tímicas (TECs) - TEC corticais (cTEC) e medulares (mTEC) - definem também os dois compartimentos principais do timo, do córtex e da medula. Ambas as linhagens originam de uma célula comum progenitora. As células $\mathrm{T}$ passam durante seu desenvolvimento através de ambos os compartimentos em um processo espacial e temporalmente ordenado. Durante a fase cortical, um repertório altamente diverso de células $\mathrm{T}$ é gerado e sujeito à seleção positiva com relação à restrição do MHC próprio. A fase medular subseqüente impõe a tolerância das células $\mathrm{T}$ ao repertório nascente por meio da seleção negativa de células efetoras autoreativas e da seleção positiva de células $\mathrm{T}$ regulatórias $\left(\mathrm{T}_{\text {regs }}\right)$. Mas cabe lembrar que as cTECs e mTECs são essenciais mas não suficientes para estes eventos da seleção (Glaber et al.,2007).

Sinais derivados de cTEC podem regular a seleção positiva de timócitos que reconhecem complexos MHC-peptídeos próprios, no entanto mTECs expressando AIRE ajuda a assegurar a tolerância aos antígenos próprios (Anderson et al., 2007). 
As células mTECs são peculiares com relação à expressão de vários antígenos de superfície incluindo MHC de classe II, CD80, Ulex europaeus aglutinina (UEA), claudin 3/4 (Glaber et al.,2007) e moléculas coestimulatórias como conseqüência de sua progressiva maturidade e agem como células apresentadoras de antígenos (APCs) no timo (Hollander, 2007; Kont et al., 2008).

Um subconjunto de mTECs expressa o gene Aire (autoimmune regulator) e em sua superfície as proteínas chamadas claudins (Cld) 3 ou 4, que são moléculas de adesão e são as principais proteínas que contribuem para a arquitetura molecular das junções celulares. Todas as células TECs $\mathrm{Cld}^{+}, \mathrm{Cld} 4^{+}$e Aire ${ }^{+}$adultas apresentam alta densidade em sua superfície de moléculas $\mathrm{MCH}$ de classe II, com forte expressão de CD80 (Hollander, 2007).

As precursoras TECs surgem exclusivamente do forro endodérmico do terceiro folheto faríngeo; lá eles invaginam para dar forma a um epitélio separado inicial (figura 4). Depois da imigração de precursores linfóides para o timo, essas células epiteliais são reorganizadas de uma estrutura plana a uma arquitetura tridimensional, uma orientação única de TECs. Embora agora esteja estabelecido que todos os subconjuntos de TECs são derivados de um precursor comum, a origem específica de mTECs Aire $^{+}$e sua relação precursor-progênie com outros subconjuntos mTECs ainda não é clara (Hollander, 2007). 


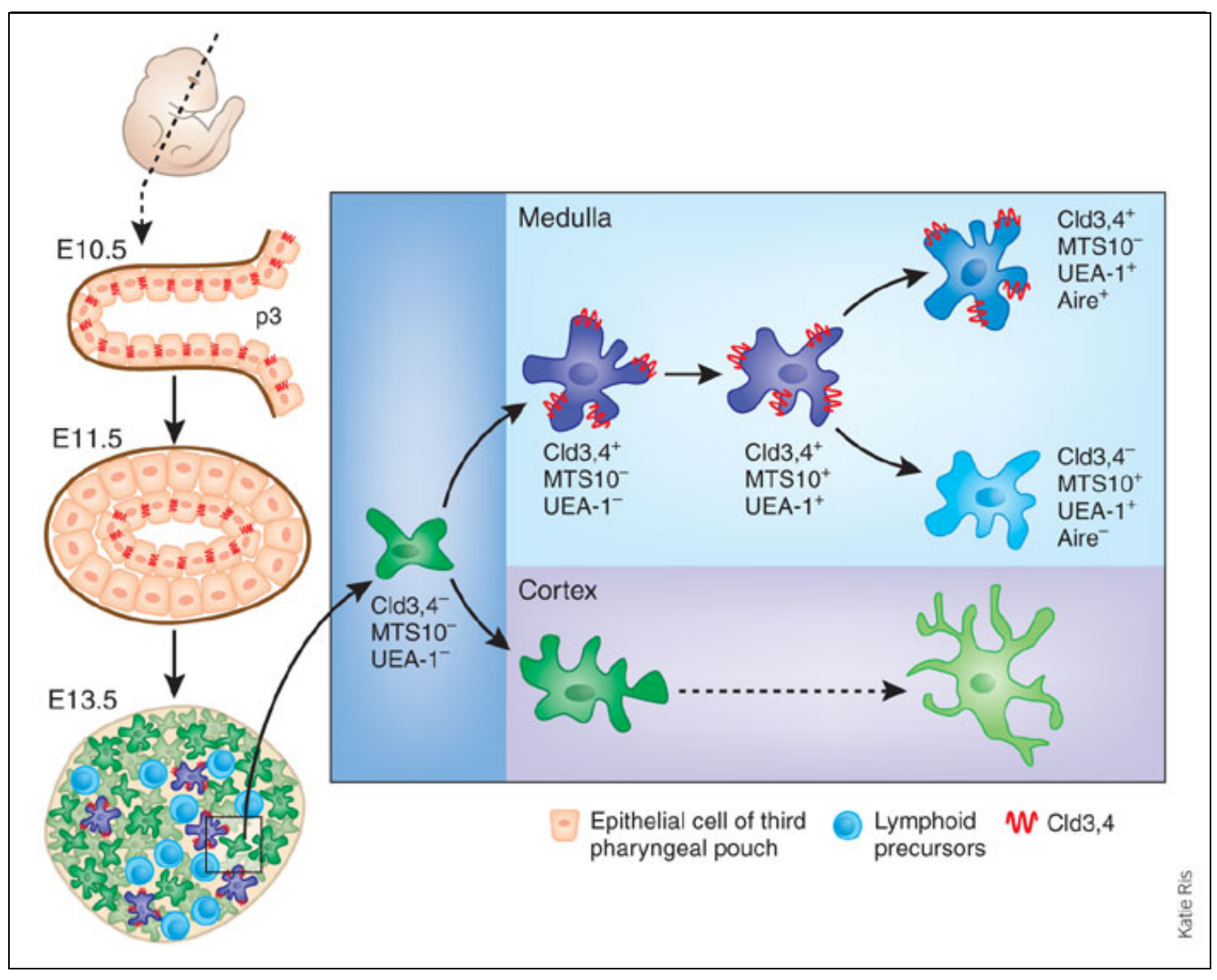

Figura 4. Diferenciação das células epiteliais tímicas (retirado de Hollander, 2007)

Ao contrário do que se assume, as mTECs não formam um esqueleto estático, mas de maneira similar ao epitélio estratificado da pele ou dos intestinos, têm um "turnover" com meia-vida de 3 a 4 semanas (Booth et al., 2000; Alonso et al., 2003; Boehm et al., 2003).

Estudos recentes documentam uma dinâmica complexa da população de mTECs. Quando o pool maduro de mTEC apresenta um turnover dentro de 3 semanas, o pool imaturo contém ambos, uma fração ciclando rapidamente e uma fração em repouso ou passando por um ciclo maior (Glaber et al., 2007).

Isto torna as mTECs um compartimento tímico altamente dinâmico. Apesar deste cell turnover altamente dinâmico, o espectro dos antígenos próprios expressos não se altera, segundo o que observa Kyewski \& 
Derbinski (2004). Os timócitos que entram na medula do timo sempre encontrarão um espectro completo de "genes promíscuos" apesar da geração contínua de mTECs.

As mTECs "imaturas" CD80-/MHC-II- expressam somente um conjunto limitado de TRAs, enquanto que mTECs "maduras" $\mathrm{CD} 0^{+} / \mathrm{MHC} \mathrm{II}^{+}$apresentam maior diversidade de TRAs incluindo aqueles genes cuja expressão é Aire-dependentes (Derbinski et al., 2005). Estes achados conduziram alguns pesquisadores a propor "o modelo de diferenciação terminal", que diz que as mTECs se submetem a um processo contínuo de diferenciação similar à pele ou ao epitélio intestinal e que o complemento completo da expressão gênica promiscua (PGE) é contingente deste processo (Gabler et al., 2007).

Nosso grupo de pesquisa, tem contribuído com observações sobre a expressão gênica promíscua no timo de camundongos isogênicos empregando a tecnologia dos cDNA microarrays. Num trabalho recente, usando culturas in vitro de timo fetal (FTOC), mostramos que o gene Aire começa sua expressão aos 16 dias de gestação e que a PGE também ocorre em FTOC, mas somente após a expressão do gene Aire, ou seja, aos 20 dias de gestação (Sousa Cardoso et al, 2006). Comparando o tempo de gestação e a duração das culturas, foi possível determinarmos a época da emergência da indução de genes de TRAs os quais representaram 57 diferentes órgãos parenquimais e 7 órgãos linfóides. Mostramos pela primeira vez que FTOC também reproduz a expressão gênica promíscua (Sousa Cardoso et al., 2006).

Foi possível observar que o conjunto inclui genes com diferentes ontologias (funções biológicas e moleculares) cujas respectivas localizações genômicas incluem praticamente todos os cromossomos, mostrando que o fenômeno é bastante abrangente. Tais observações 
foram realizadas usando RNA extraído de timos intactos, quer dos mantidos em culturas FTOC ou dos recentemente removidos dos animais.

A observação da PGE foi possível, mas como sabemos que este fenômeno ocorre nas células mTEC, no presente trabalho procuramos refinar ainda mais nosso sistema modelo e passamos a estudar células mTEC da linhagem 3.10 .

Tais células foram estabelecidas a partir do timo de camundongos da linhagem C57Bl/6 e o fenótipo de células medulares foi determinado por imunofenotipagem com anticorpo Th-4 (Mizuochi et al., 1992). Elas também foram avaliadas usando um painel de anticorpos monoclonais anti-citoqueratina, confirmando o fenótipo medular distinto (Nihei et al., 2003). Além disso, confirmou-se pela técnica de FACS que estas células são $\mathrm{CD} 80^{+}$e, portanto, aptas a PGE.

Por estes motivos, decidimos optar pelo sistema modelo de cultura de células mTECs 3.10 para estudarmos a expressão do gene Aire e sua relação com o fenômeno da PGE.

\subsection{Expressão gênica promíscua no timo e a indução de tolerância central}

Quando da fundação da teoria da seleção clonal há mais de 100 anos, Paul Ehrlich conceituou o problema da reatividade ao próprio como inerente ao sistema imune adaptativo e postulou a existência de mecanismos que podem prevenir uma reatividade deletéria ao próprio (Ehrlich \& Morgenroth, 1901).

A discriminação entre o próprio e o não-próprio tem sido considerada como um pré-requisito essencial do sistema imune dos 
invertebrados multicelulares e vertebrados. Com relação aos vertebrados, é sempre vista como a essência do sistema imune.

A formulação da teoria da seleção clonal da formação de anticorpos, o conceito de discriminação entre próprio e não-próprio, a demonstração experimental de tolerância adquirida ao próprio e a demonstração direta da deleção clonal de linfócitos auto-reativos foram importantes marcos no alcance do nosso conhecimento atual sobre tolerância ao próprio, cujo estabelecimento e a manutenção são uma exigência intrínseca do sistema imune adaptativo.

A discriminação do próprio/não-próprio é uma propriedade essencial do sistema imune que dirige uma variedade de mecanismos efetores contra agentes patogênicos enquanto ignora os constituintes próprios do organismo.

Somente quando a tolerância ao próprio está finamente balanceada é que a integridade do corpo é garantida. O timo é visto como o principal local de indução de tolerância a antígenos próprios que são expressos pelas células tímicas (tolerância central), enquanto que a tolerância a antígenos restritos a outros tecidos e órgãos parenquimais tem sido associada a mecanismos extra tímicos (tolerância periférica) (Medzhitov \& Janeway, 1997; Kyewski \& Derbinski, 2004).

Estudos prévios têm demonstrado que antígenos relacionados a tecidos próprios (TRAs) são expressos no timo e que sua expressão é necessária para a deleção de células T auto-reativas (Kyewski \& Klein, 2006). Uma característica central neste processo é a expressão gênica promíscua de TRAs pelas células epiteliais na região medular tímica, onde os TRAs são apresentados e encontrados pelos timócitos, conduzindo à indução da tolerância por deleção clonal ou inativação funcional. 
As doenças auto imunes, incluindo lúpus eritematoso sistêmico (LES), diabetes melitus do tipo 1 (DM-1) e artrite reumatóide (AR), representam desafios científicos e médicos dos mais intrigantes.

É difícil, até hoje, concluir se o problema gerado pelo desequilíbrio de reconhecimento entre o próprio e o não próprio é iniciado pelos tecidos-alvos da reação auto imune (constituintes do núcleo celular como DNA, RNA, histonas etc no LES; células $\beta$ do pâncreas no DM-1 e tecido sinovial das juntas e articulações na AR) ou se o problema está nas células $\mathrm{T}$ auto-reativas ou ainda se a origem dessas doenças está no descontrole da indução da tolerância central.

Existem evidências para as duas primeiras possibilidades, porém um ponto em comum amplamente aceito, independente da origem da auto-imunidade, é a existência dos auto-antígenos, ou seja, proteínas celulares do próprio indivíduo que são reconhecidas pelo sistema imune.

Vários trabalhos mostraram que células tímicas epiteliais medulares (mTECs) expressam moléculas que normalmente caracterizam outros tecidos ( 10\% do genoma do camundongo ou humano) representando a quase totalidade de tecidos e órgãos parenquimais.

Suspeita-se que o descontrole desta expressão promíscua pode implicar na indução deficiente de tolerância com conseqüências no surgimento de doenças auto-imunes.

Por isto, esse fenômeno foi chamado de expressão gênica promíscua (Figura 5). O conjunto de genes 'promiscuamente' expressos no timo parece ser altamente diverso, incluindo genes tecido- e sexo-específicos e genes particularmente envolvidos com o desenvolvimento (Kyewski \& Klein, 2006). 


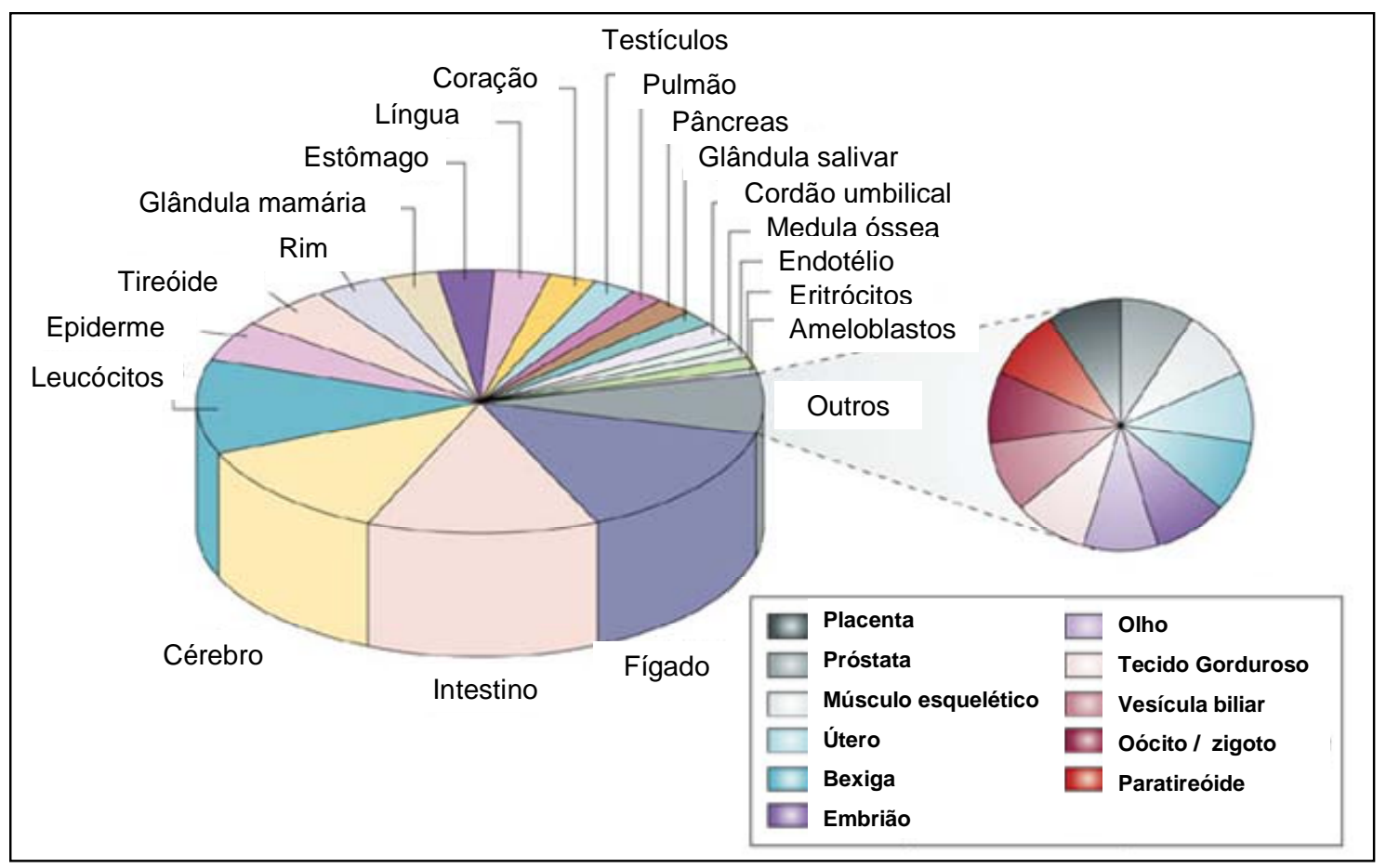

Figura 5. Representação de diversos tecidos e órgãos parenquimais no timo murino é garantida pela expressão dos antígenos relacionados a tecidos (TRAs) pelas células epiteliais (mTECs), fenômeno chamado expressão gênica promíscua (Retirado de Kyewski \& Derbinski, 2004).

A partir do ano de 2005 nosso grupo de pesquisa vem contribuindo com esta área de estudos produzindo trabalhos sobre PGE no timo murino. Descrevemos sua ocorrência in vitro em cultura de timo fetal de BALB-c (fetal thymus organ culture, FTOC) mostrando a emergência deste tipo de expressão durante o desenvolvimento ontogenético (Sousa Cardoso et al., 2006). Além disso, demonstramos que o gene Aire tem sua transcrição iniciada no timo fetal aos 16 dias de gestação e que a PGE emerge no vigésimo dia. Num outro trabalho, analisamos o efeito do background genético de linhagens isogênicas de camundongos sobre a diversidade da PGE e a distribuição genômica dos genes expressos (Magalhães et al., 2006). 
Atualmente focamos as análises de PGE do timo de linhagens de camundongos que reproduzem doenças auto-imunes tais como a NOD que reproduz diabetes melitus do tipo 1 (DM-1) (Silveira 2005; Fornari 2008) e DBA-1 que reproduz artrite reumatóide mediante imunização com colágeno (Donate 2008).

Sem reflexão poderíamos até pensar que estaríamos observando o óbvio. Mas ao invés disso, a imunologia molecular encontrou uma oportunidade ímpar de descrever e mensurar a expressão de cada um dos genes de TRAs quando passou a utilizar a tecnologia dos cDNA microarrays.

A tolerância do repertório de células T ao próprio é especificamente adquirida em cada indivíduo por caminhos diferentes no desenvolvimento das células $\mathrm{T}$ imaturas, dependentes da intensidade da interação entre o receptor de célula $\mathrm{T}$ e o peptídeo ligante de MHC próprio. Como resultado, a diversidade de antígenos próprios que são acessíveis ao repertório nascente no timo determinará a extensão e especificidade da tolerância central ao próprio (Kyewski \& Derbinski, 2004).

Vários exemplos de expressão 'aberrante' de TRAs no timo com um possível papel na tolerância de células $\mathrm{T}$ foram reportados há vários anos atrás. Porém, as implicações da noção ainda herética de regulação gênica celular tipo-específica no timo ainda não foram exploradas a contento (Kyewski \& Derbinski, 2004).

A maior implicação desta expressão heterogênea de genes no timo se associa à manutenção da homeostase imunológica do corpo, controlando as reações auto-imunes patológicas. 


\subsection{O papel do gene Autoimmune regulator (Aire)}

Um importante regulador da expressão TRAs em mTECs é o gene Aire (autoimmune regulator) localizado no cromossomo 10C1/10 $41.6 \mathrm{em}$ camundongos e 21q22.3 no homem (Mathis \& Benoist, 2007; Kont et al., 2008).

O gene Aire é um regulador de transcrição (Pitkanen \& Peterson, 2003) e controla a expressão de centenas, senão milhares de genes de TRAs, com uma tendência a genes cuja expressão é preferencial de células diferenciadas (Anderson et al., 2002; Cheng et al., 2007; Hollander, 2007). $\mathrm{O}$ produto do gene Aire (RNAm) encontra-se preferencialmente em órgãos linfóides, especialmente no timo sendo que dentro deste ele é expresso na maior parte em um conjunto de células medulares epiteliais (mTECs) mas também, em níveis muito menores, em células dendríticas (DCs) e, quanto a localização intra celular, sua proteína situa-se no núcleo (Mathis \& Benoist, 2007).

A evidência direta que Aire tem um papel na seleção negativa de células $\mathrm{T}$ veio dos modelos de camundongos TCR-transgênicos (Liston $e t$ al., 2003; Liston et al., 2004; Anderson et al., 2005).

Ainda utilizando modelos com camundongos TCR-transgênicos, Cheng et al. (2007) mostraram a correlação direta entre a perda da seleção negativa no timo e a susceptibilidade aumentada ao diabetes auto-imune, fazendo assim, uma ligação direta entre o processo de seleção airedependente no timo e a susceptibilidade auto-imune.

A purificação de mTECs de camundongos tipo selvagem e Aireknockout, seguida da análise da expressão gênica, revelou que Aire certamente promove a transcrição de um grande número genes que 
codificam antígenos de tecido periféricos (PTA) (Anderson et al., 2002 e Anderson et al., 2005) associados com a seleção negativa de células $\mathrm{T}$ auto-reativas (Nagafuchi et al., 2006). Mas Aire também regula positiva ou negativamente a transcrição em mTECs de um conjunto de genes que não codificam PTAs (Mathis \& Benoist, 2007).

$\mathrm{Na}$ ausência do gene Aire funcional, há falha das mTECs suprirem timócitos que expressam receptores TCR específicos para antígenos próprios. Como conseqüência, um grupo de células $\mathrm{T}$ auto-reativas ilude a seleção negativa no timo (e possivelmente na periferia) e aparentemente provoca as patologias auto-imunes órgão-específicas como a síndrome da poliendocrinopatia auto-imune tipo 1 , diabetes insulino-dependente, doença de Addison, vitiligo e alopecia (Hollander, 2007).

Os genes que são controlados pela proteína AIRE são altamente diversos com relação à estrutura e função, o que dificulta conclusões sobre seu modo de ação detalhado. Dados recentes indicaram que a proteína AIRE contém domínios de ligação com a molécula de DNA (Kumar et al., 2001), mas ainda nenhuma evidência foi gerada mostrando que tais domínios se ligam diretamente nos genes conhecidos controlados por AIRE (Yunxia et al., 2006).

O papel de Aire em regular a expressão promíscua de TRAs envolvida na seleção tímica encontra-se bem estabelecido, mas os mecanismos moleculares precisos da ação não estão inteiramente elucidados. A seqüência da proteína AIRE sugere que esta pode mediar a regulação transcricional. AIRE contém diversos domínios estruturais comuns às proteínas nucleares e aos fatores de transcrição, incluíndo um sinal nuclear de localização, um domínio de dimerização, e domínios DNA-ligantes putativos. Os domínios DNA-ligantes de Aire são compostos de um domínio SAND (Sp100, Aire-1, NucP41/75 e DEAF-1), 
definido pela atividade transcricional modulatória dos membros da família Sp100, e dois homeodomínios plant tipo (PHD)-zinc fingers (Cheng et al., 2007).

Uma suposição de como a proteína AIRE pode modular a seleção negativa está na ativação da expressão promíscua de proteínas periféricas nas células tímicas apresentadoras de antígeno (APC). Estudos recentes sugerem fortemente que os antígenos tecido-específicos são comumente expressos no timo e que este mecanismo é crítico em dar forma à tolerância central para proteínas periféricas (Kyewski et al., 2002). Mais especificamente, esta função foi atribuída a um subconjunto das mTECs (G8.8+ CDR-), que expressam uma gama diversa de antígenos incluindo auto-antígenos do diabetes tipo I tais como GAD65, GAD67 e insulina (Derbinski et al., 2001).

Deve-se mencionar, contudo que além das mTECs, as células dendríticas e os macrófagos intra-tímicos também expressam o gene Aire e antígenos promíscuos (Pietropaolo et al., 2002; Pugliese et al., 2002).

Entretanto, a significância destes achados para o entendimento preciso da ação molecular do gene Aire in vivo ainda não está clara. São necessárias evidências diretas de co-regulação dos genes de TRAs (expressão promíscua) devida a seqüências consenso em suas regiões de promotores/enhancers, nas quais atuaria a proteína AIRE ou mesmo outros complexos reguladores da transcrição (Kyewski \& Derbinski, 2004). Ou talvez imaginar outros mecanismos plausíveis para tentar explicar este modo de regulação gênica não convencional.

Nossa idéia é que o gene Aire regula a transcrição dos genes de TRAs por meio de interações em rede em duas etapas, ou seja, regulando primeiramente alguns genes mais importantes (nós gênicos) e estes por sua vez, regulariam um número maior de genes. 
1.4. Testando a hipótese da ação indireta do gene Aire: Construção de redes gênicas a partir de dados de microarrays

Antes de discorrer sobre redes gênicas a partir de dados de microarrays, julgamos pertinente focarmos uma das questões atuais sobre o mecanismo de ação do gene Aire contextualizando assim a necessidade da construção das mesmas.

$\mathrm{O}$ fato de Aire ser um gene codificador de um fator de transcrição faz sentido com o controle da expressão gênica nas células mTECs, isto não representa um problema. $\mathrm{O}$ que tem intrigado os pesquisadores é a grande abrangência de sua ação. A proteína AIRE apresenta domínios de ligação com a molécula de DNA idênticos a fatores de transcrição clássicos.

Entretanto, enquanto os fatores de transcrição controlam a expressão de um grupo reduzido de genes, senão de um gene específico, tudo indica que a proteína AIRE controla a expressão da maioria dos TRAs, além de outras proteínas no timo. Pode ter uma ação indutora da expressão destes genes como de inibir a de outros. Foi estimado que pode controlar a expressão de até $10 \%$ do genoma do camundongo nas células mTEC salientando que isto não tem precedentes na literatura .

Precisamente como o gene Aire (ou a proteína AIRE) controla a expressão ectópica de uma gama tão diversa de genes codificadores de TRAs, cuja regulação transcricional é bem diferente em suas localizações teciduais ? (Mathis \& Benoist, 2007).

Nossa idéia é que o gene Aire (ou a proteína AIRE) atuaria sobre o vasto número de genes de TRAs indiretamente e em rede (ou em cascatas gênicas). Como as medidas de PGE são dados de microarrays passou a ser de muito interesse a construção de redes gênicas a partir destes dados 
para abordarmos nossa proposta. Neste trabalho, construímos um sistema modelo de inibição parcial do transcrito do gene Aire pela técnica de RNA interferente nas células mTEC, determinação da PGE por microarrays e análise dos dados com o algoritmo de redes.

Os experimentos sobre a determinação da expressão gênica com microarrays oferecem uma lista de genes que governam o comportamento celular. A análise dessa lista provê uma grande quantidade de informações relevantes às quais precisam ser organizadas de maneira coerente para dar um sentido biológico a tais resultados. No contexto do estudo do comportamento celular a descrição dos mecanismos regulatórios atingiu prioridade máxima.

A regulação transcricional (DNA $\rightarrow$ RNAm) é um dos primeiros pontos de controle da expressão gênica e, num sentido amplo, pressupõese que o controle da transcrição influencia diretamente os níveis das respectivas proteínas na célula (Tegnér et al., 2003; Tabuchi et al., 2006).

Por esse motivo é que há grande interesse na pesquisa do controle da síntese de RNAm em grande escala, definindo o perfil do transcriptoma. Os desenvolvimentos recentes de tecnologias tais como DNA microarrays fizerem possível obter um volume grande de perfis da expressão gênica, permitindo a mensuração simultânea de milhares de transcritos (Gatti et al., 2007). Como a quantidade de informações geradas nesses estudos é enorme, programas computacionais específicos foram desenvolvidos, como o Cluster e Tree View, utilizado para traçar as chamadas assinaturas de expressão gênica, muito útil para o agrupamento hierárquico de amostras e de genes diferencialmente expressos (Eisen et al., 1998) ou o programa SAM (significance analysis of microarrays) utilizado para identificar os genes diferencialmente expressos com base estatística (Tusher et al., 2001). 
Os programas citados são clássicos na bioinformática de microarrays, mas ainda não respondem como montar os dados de maneira a construir um modelo preditivo de interação entre os genes. Inferir a estrutura de uma rede de interações gênicas também passou a ser uma tarefa imperativa a fim avançar nossa compreensão sobre o mecanismo molecular do funcionamento das células ao nível genômico (Kim et al., 2007).

A análise dos dados de microarrays incluiu agora um foco na reconstrução de redes regulatórias entre os genes, visando encontrar e entender as interações gene-a-gene a partir de dados de expressão (Wang et al., 2006).

Atualmente concebe-se que a maioria dos relacionamentos bioquímicos entre genes, proteínas e outros substratos orgânicos devam ser many-to-many, significando que um componente pode ter muitas funções e uma função pode ser influenciada por muitos componentes. Para compreender estes relacionamentos complexos, a estrutura de um sistema biológico, tal como o relacionamento regulador entre os genes precisa ser identificado.

Os métodos de engenharia reversa fornecem uma boa maneira de se modelar interações baseadas em dados da expressão gênica durante o curso do tempo, cujos dados foram gerados por experimentos com microarrays. A rede gênica reconstruída terá por enquanto uma base puramente de probabilidade e estatística e é claro que deverá ser finalmente validada experimentalmente (Wu et al., 2004).

Uma grande variedade de metodologias vem sendo proposta para inferir redes gênicas regulatórias a partir de dados temporais. Entre esses métodos estão modelos discretos, como as redes Booleanas e Baysianas, modelos contínuos, como as redes neurais e equações diferenciais. Todos 
esses modelos levam em consideração que o nível de expressão de um gene, num determinado intervalo de tempo é dado em função do nível de expressão dos outros genes nos tempos anteriores (Wang et al., 2006).

A inferência da arquitetura de redes gênicas a partir de dados temporais obtidos de tecnologias experimentais, como os microarrays, ajuda a entender e esclarecer o comportamento do sistema em relação à expressão gênica e a regulação envolvida nessa expressão; fazendo uso da bioinformática.

Dentre os algoritmos propostos na literatura para a inferência de redes gênicas, existem aqueles baseados no formalismo matemático da teoria da informação, como o ARACNE (Basso et al, 2005; Margolin et al, 2006), os que consideram equações diferenciais ordinárias, como os programas NIR, NMI e TSNI (Gardner et al, 2003; di Bernardo et al, 2005; Bansal et al, 2006), e também aqueles que solucionam o problema de inferência por meio de redes bayesianas, como o Banjo (Yu et al, 2004) e o GeneNetwork (Wu et al, 2003).

Comparando esses algoritmos, o Genenetwork foi escolhido para o presente trabalho devido suas características peculiares. $\mathrm{O}$ algoritmo realiza a interpolação de dados e tem habilidade de calcular a interação entre mais de mil genes. Além disso, a rede resultante é descrita por um gráfico orientado, no qual as setas positivas indicam indução e as negativas indicam repressão entre genes, respectivamente.

Num esforço para conseguirmos um melhor entendimento dos dados de microarrays sobre a PGE em células mTEC 3.10 evidenciando o efeito do gene Aire, construímos então as redes de interações baseadas na estatística Bayesiana. 
Esse método de bioinformática nos ajudou testarmos a hipótese de que o gene Aire poderá atuar no controle da PGE de maneira indireta, ou seja, inicialmente controlando alguns genes-chave (nós gênicos) e estes por sua vez controlando um número maior de genes, ou seja, por meio de redes. 
Hipóteses 


\section{HIPÓTESES}

2.1. Células tímicas epiteliais medulares (mTECs) expressam, em cultura, grande quantidade de genes codificadores de antígenos relacionados a tecidos (expressão gênica promíscua).

2.2. O gene AIRE (autoimmune regulator) controla a expressão gênica promíscua nas células mTEC atuando por meio de interações em rede com outros genes. 
Objetivos 


\section{OBJETIVOS}

3.1. Avaliar a expressão gênica diferencial de TRAs (expressão gênica promíscua) em células tímicas epiteliais medulares (linhagem mTEC 3.10) usando a tecnologia dos cDNA microarrays.

3.2. Inibir o transcrito do gene Aire (autoimmune regulator) em células tímicas epiteliais medulares da linhagem mTEC 3.10 utilizando o método de RNA interferente (RNAi).

3.3. Avaliar o efeito da inibição do transcrito do gene Aire sobre a expressão gênica promíscua de células mTEC 3.10.

3.4. Construir redes de interações gênicas a partir de dados de microarrays de células tímicas epiteliais medulares (mTEC 3.10) após a inibição do transcrito do gene Aire com o intuito de observarmos as cascatas de regulação da expressão gênica promíscua. 
Material e Métodos 


\section{MATERIAL E MÉTODOS}

\subsection{Linhagem celular mTEC 3.10 (células tímicas epiteliais medulares)}

No presente trabalho utilizou-se a linhagem de células tímicas medulares primárias (mTEC 3.10), gentilmente cedida pelo Prof. Dr. Wilson Savino, coordenador do Laboratório de Pesquisas sobre o Timo da Fundação Instituto Oswaldo Cruz (FIOCRUZ) do Rio de Janeiro.

As células da linhagem 3.10 foram estabelecidas a partir do timo de camundongos da linhagem $\mathrm{C57Bl/6}$ e o fenótipo de células medulares foi determinado por imunofenotipagem com anticorpo anti Th-4 (Mizuochi et al., 1992). Elas foram avaliadas usando um painel de anticorpos monoclonais anti-citoqueratina, confirmando o fenótipo medular distinto (Nihei et al., 2003). Além disso, confirmou-se pela técnica de FACS que estas células são CD80+ e, portanto, aptas a PGE (figura 6).

As células da linhagem 3.10 são aderentes e foram cultivadas em garrafas de cultura de $75 \mathrm{~cm}^{3}$ contendo $20 \mathrm{ml}$ de meio RPMI 1640 e 10\% de soro bovino fetal $(\mathrm{SBF})$ a $37^{\circ} \mathrm{C}$, em estufa com atmosfera de $5 \% \mathrm{CO}_{2}$. 


\section{Padrão de expressão de CD80 em mTEC (3.10)}

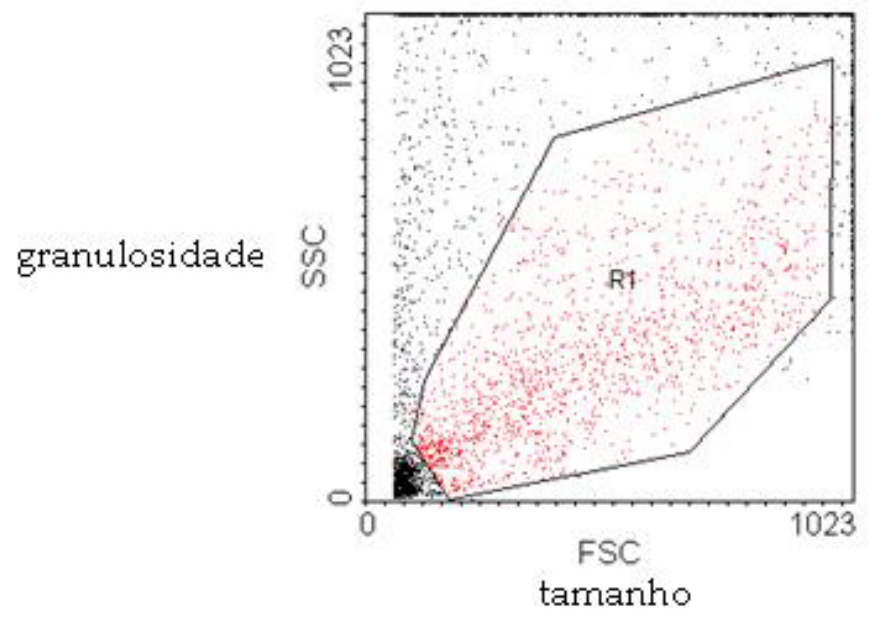

Expressão dentro da região R1

CD80-PE

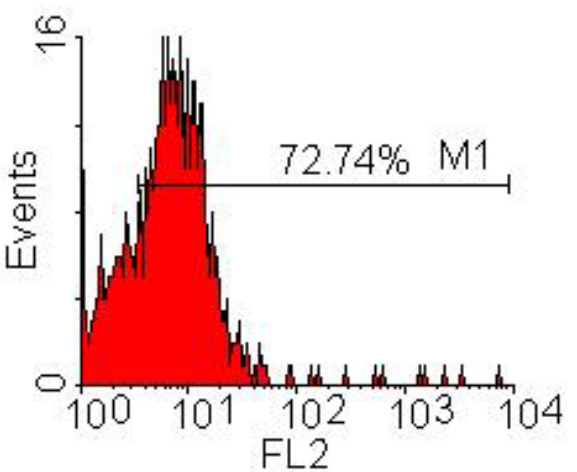

$\operatorname{Ig} G$

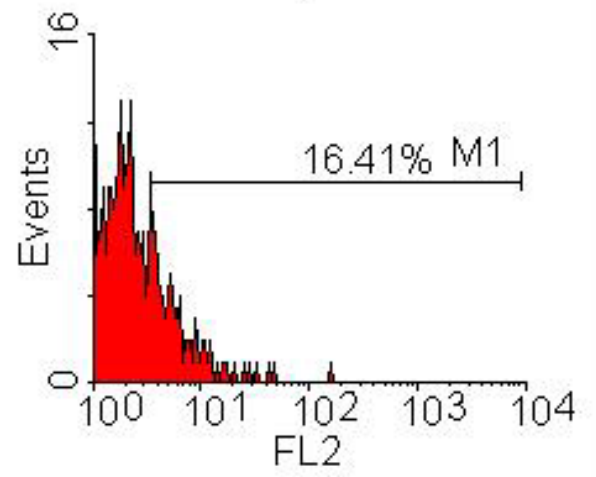

Porcentagem de células 3.10 que expressam CD80:

$(72.74 \%-16.41 \%=56.33 \%)$

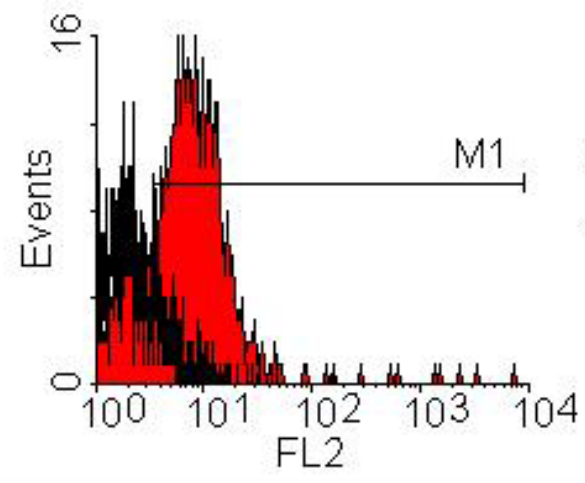

Figura 6. Padrão de expressão de CD80 em mTEC 3.10 


\subsection{Inibição seletiva do transcrito do gene Aire com RNA interferente (RNAi).}

\subsubsection{Determinação da seqüência de RNAi anti-Aire.}

O ensaio de silenciamento do transcrito do gene Aire foi realizado utilizando o sistema de RNAi do Kit TriFECTa ${ }^{\mathrm{TM}}$ (IDT - Integrated DNA Tecnologies, Coralville, IA, USA). O kit inclui três seqüências diferentes de RNAi anti-Aire, as quais devem ser previamente testadas buscando a melhor eficiência de inibição do transcrito no modelo de estudo. Além das seqüências anti-Aire, outras três seqüências estavam incluídas no kit: 1) RNAi irrelevante marcado com $\mathrm{Cy} 3$ utilizado para medir a eficiência de transfecção (microscopia de fluorescência), 2) uma seqüência duplex de RNAi irrelevante, o qual não é capaz de alterar a expressão gênica nas células em estudo e 3) um controle positivo, constituída de uma seqüência RNAi anti-o transcrito do gene constitutivo HPRT (hypoxanthine guanine phosphoribosyl transferase), utilizada para avaliar se o processo de transfecção e o sistema modelo são adequados para inibição com RNAi.

O método escolhido para a transfecção das células mTEC em cultura foi o de lipofecção utilizando o Hiperfect Transfection Reagent® da Qiagen (Hilden, Alemanha), seguindo instruções do fabricante.

Para se determinar qual a melhor concentração e qual o melhor duplex para o silenciamento do transcrito de Aire, realizou-se um experimento piloto onde as três seqüências anti-Aire e as demais seqüências controle foram testadas nas concentrações de 2,5; 5,0 e 10,0 $\eta$ M. Finalmente amostras de cDNA oriundas das células mTEC tratadas 
com estes RNAs foram submetidas a reações de PCR (método de RTPCR) para avaliarmos a melhor seqüência inibitória.

As reações de RT-PCR do experimento piloto para a seleção da seqüência de RNAi anti-Aire foram realizadas a partir de $2 \mu \mathrm{g}$ de cada amostra de RNA, que foram convertidas a cDNA utilizando a enzima transcriptase reversa SuperScript II ${ }^{\circledR}$ (Invitrogen). Utilizamos então $5 \mu \mathrm{L}$ do produto da reação e a amplificação por PCR foi feita em diluições sucessivas (1:1 a 1:128) em cada reação de RT-PCR semi-quantitativa. As seqüências dos oligonucleotídeos primers utilizados encontram-se na Tabela I.

As condições de PCR foram: mix com volume final de $25 \mu \mathrm{l}$, contendo $200 \mu \mathrm{M}$ de dNTPs, 1,5 mM de $\mathrm{MgCl}_{2}, 50 \mathrm{mM} \mathrm{KCl,} 10$ mMTris$\mathrm{HCl}\left(\mathrm{pH} 8,4\right.$ a $\left.25^{\circ} \mathrm{C}\right), 10 \mu \mathrm{M}$ de cada primer e $2 \mathrm{U}$ de Taq DNA polimerase. Ciclagem térmica: trinta e cinco ciclos foram realizados, cada um com três passos. Para o gene Aire: desnaturação a $94^{\circ} \mathrm{C}, 30$ segundos; anelamento a $57^{\circ} \mathrm{C}, 30$ segundos; extensão a $72^{\circ} \mathrm{C}, 30$ segundos e para o gene HPRT: desnaturação a $94^{\circ} \mathrm{C}, 30$ segundos; anelamento a $60^{\circ} \mathrm{C}, 30$ segundos; extensão a $72^{\circ} \mathrm{C}, 30$ segundos.

Os produtos da amplificação foram submetidos à eletroforese em gel de agarose $2 \%$ corado com brometo de etídeo. 
Tabela I. Oligonucleotídeos primers utilizados nas reações de RT-PCR. $($ For $=$ forward, $\operatorname{Rev}=$ reverse $)$

\begin{tabular}{|c|c|c|}
\hline Gene & Seqüência dos primers & Produto PCR (pb) \\
\cline { 1 - 2 } HPRT(For) & 5' GCTTGCTGGTGAAAAGGACCTCTCGAAG 3' & \multirow{2}{*}{217} \\
\cline { 1 - 2 } HPRT(Rev) & 5'CCCTGAAGTACTCATTATAGTCAAGGGCAT3' & \\
\hline Aire (For) & 5' CATCCTGGATTTCTGGAGGA 3' & \\
\hline Aire (Rev) & 5' GCTCTTTGAGGCCAGAGTTG 3' & \\
\hline
\end{tabular}

4.2.2. Silenciamento do transcrito do gene Aire em cultura de células mTEC 3.10 .

Ao atingirem semiconfluência as células da linhagem 3.10 foram destacadas das garrafas de cultura de $75 \mathrm{~cm}^{3}$ utilizando-se $9.5 \mathrm{ml}$ de solução de tripsina 1x (2.5g de tripsina suína por litro em HBSS) $+0.5 \mathrm{ml}$ de EDTA pH 8.0 por 5 minutos e as células foram contadas em câmara de Newbauer. As células foram colhidas por centrifugação a 1000xg durante 5 minutos. $5 \times 10^{5}$ células foram semeadas em garrafas de cultura de $25 \mathrm{~cm}^{3}$ contendo $2,3 \mathrm{ml}$ de meio RPMI e $10 \%$ de soro fetal bovino (SFB), uma hora antes do início do experimento com RNAi anti-Aire e colocadas em condições normais de cultura. Após colocar as culturas em estufa, procedeu-se com a preparação dos complexos RNAi-lipofectamina. Cinco nanomoles de RNAi foram gentilmente misturados à $100 \mu \mathrm{l}$ de MEM filtrado sem SBF e então foram adicionados $6 \mu \mathrm{l}$ de Hiperferct (Qiagen). Essa mistura foi vigorosamente agitada durante 10 segundos e em seguida incubadas 10 minutos à temperatura ambiente para a formação 
dos complexos de transfecção RNAi-lipofectamina. Os complexos foram adicionados à cultura, permanecendo por 42 horas. Após 24 horas que as células foram semeadas, foram adicionados mais $2 \mathrm{ml}$ de RPMI contendo $10 \%(\mathrm{SBF})$.

Foram utilizados 4 controles: 1) mTEC 3.10 sem RNAi; 2) mTEC 3.10 em presença apenas de lipofectamina; 3) mTEC 3.10 em presença de um RNAi irrelevante, sem a capacidade de silenciar qualquer gene de camundongo; 4) mTEC 3.10 na presença de um RNAi anti-HPRT, um controle positivo, que indica a funcionalidade do método.

Para a avaliação da eficiência da transfecção fez-se uso de microscopia fluorescente onde a seqüência duplex de RNAi irrelevante marcada com Cy3 foi testada em diferentes concentrações: $1 ; 2.5 ; 5$ e 10 $\eta \mathrm{M}$.

A avaliação da transfecção das células mTEC 3.10 utilizando microscopia de fluorescência foi realizada no Laboratório da Profa. Dra. Elza Tiemi Sakamoto-Hojo no Departamento de Genética da Faculdade de Medicina de Ribeirão Preto.

\subsection{Extração de RNA total}

A fim de prevenir da contaminação por ribonucleases durante a extração e manuseio dos RNAs, toda a vidraria, tubos plásticos, espátulas e pinças utilizadas foram previamente autoclavados. $\mathrm{O}$ material plástico (tubos e ponteiras) eram novos e previamente autoclavados. Todo o procedimento foi realizado usando luvas de látex sem talco e descartáveis.

Após 42 horas o RNA total de cada cultura foi extraído utilizando- 
se $\mathrm{o}$ reagente MirVANA $^{\text {TM }}$ (Ambion), seguindo as instruções do fabricante. As células da linhagem 3.10 foram destacadas das garrafas de cultura de $25 \mathrm{~cm}^{3}$ utilizando-se $4.75 \mathrm{ml}$ de solução de tripsina $1 \times(2.5 \mathrm{~g}$ de tripsina suína por litro em HBSS) $+0.25 \mathrm{ml}$ de EDTA pH 8.0 por 5 minutos, seguido de inativação da tripsina com meio de cultura + SBF e colhidas por centrifugação a 1000xg durante 5 minutos. As células foram lavadas duas vezes com PBS 1x, seguida de centrifugação a 1000 xg durante 5 minutos. Adicionou-se $1000 \mu \mathrm{l}$ de solução de lise. Agita-se vigorosamente (pipetagem e 10 segundos no vórtex) para lisar completamente as células e obter um lisado homogêneo. Adiciona-se 100 $\mu l$ de miRMA Homogenate Additive e mistura bem (vórtex 15 segundos). Deixa a mistura no gelo por 10 minutos. Adiciona-se $1000 \mu$ de ÁcidoFenol:Clorofórmio e agita-se vigorosamente no vórtex por 60 segundos. $\mathrm{O}$ lisado é então centrifugado a 10000 xg por 5 minutos à temperatura ambiente. A fase aquosa é cuidadosamente transferida para um novo tubo e então é adicionado $1.25 x$ volume recuperado após a centrifugação de ethanol 100\% à temperatura ambiente. Para cada amostra é montada uma coluna em um tubo coletor. $700 \mu \mathrm{l}$ da mistura foram pipetados na coluna e centrifugados 15 segundos à 10000xg. O líquido foi descartado e o procedimento foi repetido até que toda a mistura lisado/etanol tenha sido filtrado. Aplicou-se $700 \mu \mathrm{l}$ de miRNA Wash Solution 1 à coluna e centrifugou-se por 10 segundos à 10000 xg. Descartou-se o líquido e 500 $\mu 1$ de miRNA Wash Solution 2/3 foram aplicados à coluna e centrifugados 10 segundos à 10000 xg. Repetiu-se o último passo e, após descartar o líquido, centrifugou-se 1 minuto para remover resíduos líquidos no filtro. A coluna foi transferida para um tubo novo coletor e a ela foram adicionados $100 \mu \mathrm{l}$ de água DEPC pré-aquecida $\left(95^{\circ} \mathrm{C}\right)$. Centrifugou-se 30 segundos para recuperar o RNA. 
Ao RNA total recuperado na etapa anterior foram adicionados três volumes de etanol absoluto gelado a fim de precipitar e concentrar a amostra e a mistura deixada a $-20^{\circ} \mathrm{C}$ por pelo menos 18 horas.

O RNA total foi coletado por centrifugação a frio e o precipitado foi lavado duas vezes com $1000 \mu \mathrm{L}$ de etanol $70 \%$ também a frio. O excesso de etanol foi removido do precipitado de RNA por evaporação em tubo aberto tomando cuidado para não ressecar as amostras. Finalmente as amostras de RNA foram dissolvidas em $13 \mu \mathrm{L}$ de água Milli-Q estéril.

O grau de pureza das preparações de RNA total foi calculado por medidas espectrofotométricas (GENEQUANT - AMERSHAM PHARMACIA BIOTECH) calculando as razões entre as absorbâncias; $\mathrm{A}_{260} / \mathrm{A}_{280} \sim 2,0$ indicando que a preparação estava livre de proteínas e $\mathrm{A}_{220} / \mathrm{A}_{260} \sim 0,7$ livre de fenol. A integridade das preparações foi avaliada por meio de eletroforese em gel de agarose corado com brometo de etídeo seguindo protocolo convencional.

\subsubsection{Quantificação de RNA total}

O precipitado de RNA total era dissolvido em $13 \mu$ de água MilliQ previamente tratada com DEPC. A solução de RNA era então diluída 100X e submetida a dosagens em espectrofotômetro usando luz ultravioleta (GENEQUANT - AMERSHAM PHARMACIA BIOTECH). As dosagens tiveram como base a seguinte estimativa: $1 \mathrm{U}$ de $\mathrm{A}_{260}=40 \mu \mathrm{g}$ RNA/mL. 


\subsection{Eletroforese de RNA total em gel denaturante (Sambrook et al., 1989)}

\subsubsection{Preparação do gel}

A agarose $(70 \mathrm{ml})$ foi fundida em água Milli-Q autoclavada (1,5\% de agarose), e quando à temperatura de $60^{\circ} \mathrm{C}$, é adicionado $20 \mathrm{ml}$ de formaldeído (37\%) e $22 \mathrm{ml}$ de tampão de migração 5X concentrado (20,6 g de MOPS [ácido propano sulfônico 3-(N-morfolino)], dissolvidos em 800 $\mathrm{ml}$ de acetato de sódio 50mM, pH 7,0 ajustado com $\mathrm{NaOH} 2 \mathrm{~N}$ e adicionados $10 \mathrm{ml}$ de EDTA 0,5 M pH 8,0, volume final ajustado para $1000 \mathrm{ml})$. O gel foi solidificado em suporte de acrílico que foi, inicialmente, tratado com $\mathrm{NaOH} 0,5 \mathrm{M}$ por 10 minutos, assim como a cuba e o pente para eliminação de RNAase sendo posteriormente lavado com água Milli-Q autoclavada.

\subsubsection{Preparação das amostras de RNA}

Em um tubo tipo Eppendorf novo e autoclavado colocado em banho de gelo foram adicionados 4,5 $\mu \mathrm{l}$ de uma solução de RNA (5 $\mu$ g de RNA), $2 \mu 1$ de tampão de migração (5X); 3,5 $\mu \mathrm{l}$ de formaldeído (37\%) e $10 \mu \mathrm{l}$ de formamida. A solução é, então, incubada a $65^{\circ} \mathrm{C}$ por 15 minutos, sendo posteriormente resfriado imediatamente em banho de gelo. Foi adicionado tampão de aplicação (1/10 do volume) e, as amostras aplicadas no gel. A eletroforese foi realizada à $80 \mathrm{~V}$ por cerca de 2,5 a 3 horas. Para o cálculo do peso molecular dos RNAs utilizamos RNAs ribossômicos $28 \mathrm{~S}(4,8 \mathrm{~Kb})$ e $18 \mathrm{~S}(1,9 \mathrm{~Kb})$ como marcadores. 


\subsection{PCRs semi-quantitativas para os genes Aire e HPRT.}

Dois microgramas de cada amostra de RNA total foram convertidos a cDNA utilizando a enzima SuperScript $\mathrm{II}^{\circledR}$ (Invitrogen) em uma reação de rt-PCR. Cinco microlitros do produto da reação de rt-PCR foram amplificados em diluições sucessivas $(1: 2,1: 4,1: 8$, até 1:1024) em cada reação de PCR semi-quantitativa. Foram usados pares de primers específicos (Tabela 1) para ambos os genes: Aire e HPRT. Um volume final de $25 \mu$ de uma reação típica de PCR, contendo $200 \mu \mathrm{M}$ de dNTP, 1,5 $\mathrm{mM}$ de $\mathrm{MgCl}_{2}, 50 \mathrm{mM} \mathrm{KCl}, 10$ mMTris-HCl (pH 8,4 a 25ㄷ), $10 \mu \mathrm{M}$ de cada primer e 2 U de Taq DNA polimerase, foi submetida a ciclagem térmica. Trinta e cinco ciclos foram realizados, cada um com três passos. Para o gene Aire foi desnaturação: $94^{\circ} \mathrm{C}, 30$ segundos; anelamento: $57^{\circ} \mathrm{C}$, 30 segundos; extensão: $72^{\circ} \mathrm{C}, 30$ segundos e para o gene HPRT foi desnaturação: $94^{\circ} \mathrm{C}, 30$ segundos; anelamento: $60^{\circ} \mathrm{C}, 30$ segundos; extensão: $72^{\circ} \mathrm{C}, 30$ segundos. Os produtos da amplificação foram submetidos a uma eletroforese em gel de agarose $2 \%$ em paralelo ao lado de um marcador de peso molecular de 50 pb (Promega, EUA).

\subsection{Preparação de cDNA microarrays em lâminas de vidro}

\subsubsection{Biblioteca de cDNAs murinos}

Nosso laboratório mantém uma biblioteca de cDNA murino (Biblioteca MTB IMAGE), com cerca de 9.000 clones de timo provenientes do "IMAGE Consortium" (http://image.llnv.gov). São clones com seqüências "expressed sequence tags" (EST), cujos tamanhos moleculares 
variam de 500 a 1.500 pb, e está totalmente caracterizada, cujos clones estão seqüenciados e catalogados. Os clones estão identificados com seus respectivos "accession numbers" (Acc) no GenBank, Clone ID, o nome do gene e a posição de cada clone nas placas de 384 poços em planilhas do programa Excel $®$ Microsoft. Conservamos esta biblioteca em E. coli em placas de microtitulação (384 poços) a $-80^{\circ} \mathrm{C}$ (material gentilmente cedido pela Dra. Catherine Nguyen, do INSERM-TAGC ERM 206, Marseille, França).

4.6.2. Amplificação de cDNA para a confecção de microarrays

Os clones de E. coli da biblioteca de cDNA IMAGE murina, repicados em placas de 384 poços contendo meio de cultura 2 X LB + ampicilina foram incubados durante 16 horas, na proporção de $5 \mu 1$ da cultura original diluídos em $45 \mu 1$ de meio de cultura 2X LB (volume final em cada poço: $50 \mu \mathrm{l}$ ). A seguir uma alíquota de $8 \mu \mathrm{l}$ da cultura foi transferida para outra placa de 384 poços, contendo $72 \mu 1$ de água deionizada estéril, e esta placa incubada a $95^{\circ} \mathrm{C}$ por $10 \mathrm{~min}$. para lise das células. Após centrifugação a $4000 x \mathrm{xg}$ por $5 \mathrm{~min}$. foi retirado $10 \mu \mathrm{l}$ do sobrenadante e adicionado a $40 \mu \mathrm{l}$ de um mix para PCR contendo tampão da reação de PCR $(10 X)$, solução de dNTP $(2 \mathrm{mM})$, primers com seqüências consenso aos três vetores presentes na biblioteca $(10 \mu \mathrm{M})$, primer LBP $1 S$ (5`TGTGGATTGTGAGCGGATAA3`) e primer 1AS (5’GGGTTGAATTAGCGGAACG3’), Taq polimerase $(5 \mathrm{U} / \mu \mathrm{l})$ e água deionizada estéril q.s.p $50 \mu$ l. O programa para amplificação dos insertos teve como base aquele descrito por Menossi et al., 2000: 5 minutos a $94^{\circ} \mathrm{C}$, seguidos de 30 ciclos $\left(94^{\circ} \mathrm{C}\right.$, por 30 segundos; $55^{\circ} \mathrm{C}$ por 30 segundos, $72^{\circ} \mathrm{C}$ por 2 minutos), seguida por uma extensão final de 7 minutos a $72^{\circ} \mathrm{C}$ e 5 
minutos a $4{ }^{\circ} \mathrm{C}$. Foi realizada em um aparelho termociclador "Mastercycler Gradient" (Eppendorf), em placas de PCR seladas com adesivo laminado para evitar evaporação.

Cerca de 2 amplificações PCR de cada clone foram realizadas, sempre totalizando $50 \mu 1$ de volume.

A avaliação da qualidade dos produtos amplificados pela PCR foi feita em gel de agarose 1\%, em tampão TAE 1X (Tris-acetato 0,04 M, EDTA $0,001 \mathrm{M})$ contendo brometo de etídio $(10 \mathrm{mg} / \mathrm{ml})$ a $80 \mathrm{~V}$, durante 15 min. A visualização das bandas foi realizada utilizando transluminador U.V. e fotografados em Polaroid.

\subsubsection{Purificação dos produtos de PCR}

Para obtenção de uma eficiente fixação dos insertos de cDNA amplificados tanto nas membranas de náilon ou nas lâminas de vidro é necessária a remoção de nucleotídeos não incorporados e primers da reação de PCR (Hedge et al. 2000). Utilizamos a purificação dos produtos de PCR por precipitação com etanol.

Os produtos de PCR $(50 \mu \mathrm{l})$ foram transferidos para placas de cultivo com fundo em "U" e foram adicionados $10 \mu \mathrm{l}$ de acetato de sódio $3 \mathrm{M} \mathrm{pH} \mathrm{4,8} \mathrm{em} \mathrm{cada} \mathrm{poço} \mathrm{de} \mathrm{uma} \mathrm{placa} \mathrm{de} 96$ poços. Em seguida, os produtos das duas PCR foram agrupados, totalizando $100 \mu \mathrm{l}$, que foram transferidos para esta mesma placa. Após a adição de $100 \mu \mathrm{l}$ de etanol absoluto, as placas foram incubadas por 16 horas (overnight) a $-20^{\circ} \mathrm{C}$. Após este tempo, as placas foram centrifugadas a 4000xg por $60 \mathrm{~min}$. a 2$8^{\circ} \mathrm{C}$. O sobrenadante foi desprezado e o pellet foi ressuspenso em $100 \mu \mathrm{l}$ de etanol $70 \%$. As placas foram novamente centrifugadas a 4000xg por 30 
min a $2-8^{\circ} \mathrm{C}$. O sobrenadante foi novamente desprezado e a placa secou à temperatura ambiente overnight. Após a placa seca, o pellet foi ressuspenso em $50 \mu \mathrm{l}$ de água deionizada autoclavada.

Uma alíquota de $5 \mu \mathrm{l}$ destes produtos foi aplicada em gel de agarose $1 \%$ contendo brometo de etídeo, visualizado em transluminador U.V. e fotografado em Polaroid para avaliar a qualidade dos produtos amplificados.

As placas foram secas em forno a $42^{\circ} \mathrm{C}$ e adicionou-se $27 \mu 1$ de solução de espotagem (DMSO 50\% - dimetil sulfóxido) por poço da placa. Em seguida, estas placas foram levadas ao freezer $-20^{\circ} \mathrm{C}$ e os produtos foram congelados e descongelados por 3 vezes para uma melhor dissolução do DNA concentrado. Posteriormente, os clones foram passados para as placas do robô, e estocadas a $4^{\circ} \mathrm{C}$ até a deposição dos produtos de PCR em lâminas de vidro.

\subsubsection{Confecção das lâminas de microarrays}

Amostras de produtos de PCR purificados foram preparadas para deposição em lâminas de vidro adicionando-se mesmo volume (1:1) de Reagente D (GE Healthcare) e transferidas para microplacas de 384 poços (Genetix). Por meio de um robô Array Spotter III (Amersham Molecular Dynamics) as amostras foram depositadas por um conjunto de 12 canetas que deposita um volume de $0,9 \mathrm{nl}$ da amostra baseada na ação de capilaridade em superfície de lâminas de vidro (Corning ${ }^{\circledR}$ - UltraGaps 40015). Após a deposição de cada conjunto de amostras as canetas foram lavadas automaticamente em uma estação de lavagem que utiliza sucessivamente água purificada (18 megohm/cm), etanol absoluto 
(Merck), solução 0,2 $\mathrm{M}$ de $\mathrm{KOH}$ e água novamente. As canetas foram secas com nitrogênio 5.0 analítico antes das próximas amostras serem carregadas. A câmara de deposição das amostras em lâminas do robô Array Spotter III possui temperatura e umidade controladas. A umidade relativa de deposição das amostras foi de $\approx 55 \%$ e a temperatura foi de $\approx$ $25^{\circ} \mathrm{C}$. Além disso, este robô está instalado numa sala especial com ar limpo (sala limpa classe 10.000).

Após a deposição e secagem de todas as amostras nas lâminas, o DNA foi fixado por "cross-linking" por meio de irradiação ultravioleta a $500 \mathrm{~mJ}$ de energia (Hoefer UV Crosslinker).

\subsection{Delineamento das hibridações em microarrays}

Uma escolha chave em um projeto que envolve a tecnologia de microarray é utilizar comparações que podem ser diretas ou indiretas isto é, estabelecer comparações dentro ou entre as lâminas. Existem três principais tipos de delineamento: 1) inversão de corantes (dye-swap), 2) experimentos em volta (looping) e 3) RNA de referência (figura 7). Mas, não existe um delineamento experimental ideal para todas as situações, ou seja, diferentes desenhos experimentais são necessários para contextos experimentais diferentes. Qualquer que seja o tipo de desenho utilizado será requerido o mesmo número de hibridações, e a decisão sobre o tipo de delineamento deve considerar a pergunta do trabalho. 


$\begin{array}{|llll|}6 \text { hibridações } & \text { 1) Troca de fluorocromos (dye swap) } \\ 6 \text { hibridações } & & \end{array}$

Figura 7. Esquema dos principais tipos de delineamento experimental para microarrays. A, B e C - amostras controle; $\mathrm{A}^{\prime}, \mathrm{B}^{\prime}$ e $\mathrm{C}^{\prime}$ - amostras teste; $\mathrm{R}$ - pool de RNA de referência.

O pool de RNA derivado de linhagens celulares é a amostra de referência mais utilizada atualmente. Para fornecer a cobertura ótima dos genes depositados na lâmina, as amostras de referência são freqüentemente constituídas de diferentes linhagens celulares oriundas de vários tecidos. Nos experimentos com microarrays do presente trabalho adotou-se a estratégia do RNA de referência ao invés do dye-swap, pois para realizar os experimentos com troca de corantes seria necessário marcar a mesma amostra de RNA com os dois corantes (Cy3 e Cy5). Porém, tal abordagem passa a ser inviável, pois a quantidade de RNA seria insuficiente para a repetição das hibridações.

O pool de RNA de referência neste caso foi uma mistura "equimolar" de RNA total de timos de camundongos C57BL/6 adultos cujas amostras foram extraídas exatamente nas mesmas condições das experimentais. Como neste trabalho escolheu-se o uso de RNA de referência, segue algumas considerações: 
Ensaios de co-hibridação diferencial usando microarrays medem a expressão gênica relativa de amostras emparelhadas e de uma amostra referência, sendo que o poder da análise de microarray vem da identificação de padrões informativos de expressão de um gene através das experiências múltiplas. O cumprimento destes objetivos é facilitado usando uma amostra de referência comum para todos os experimentos que forneça uma medida da expressão base para cada gene, permitindo a normalização e a comparação de experimentos independentes.

Um vasto número de linhagens celulares pode não melhorar necessariamente a representatividade total dos genes depositados no array, pois algumas linhagens celulares expressam significativamente mais genes do que outras e, nem todas as linhagens expressam todos os genes em níveis semelhantes. Misturar RNA de muitas linhagens celulares pode diluir os transcritos raros de modo que a sua representação no "pool" final do RNA corre o risco de ficar abaixo do limite detectável (Yang et al. 2002).

O uso de RNA de referência passou a ser uma abordagem bastante adequada eliminando assim a necessidade de repetir as marcações de uma mesma amostra com dois corantes (dye-swap) e, conseqüentemente evitando as diferenças de incorporação.

O delineamento das hibridações de microarrays consistiu em marcar todas as amostras de células mTECs em diferentes condições com fluorocromo Cy3 e combiná-los numa mesma lâmina com amostras de RNA (cDNA) de referência marcados com Cy5. Neste trabalho, o RNA de referencia utilizado foi um pool de RNAs de timos de seis camundongos da linhagem $\mathrm{C} 57 \mathrm{Bl} / 6$. 
As hibridações com cDNAs oriundos de RNA referência são importantes para os cálculos de normalização, pois reflete a estimativa da quantidade de material depositado em cada ponto do microarray (alvo).

\subsection{Marcação das sondas complexas de cDNA com fluorocromos CY3 e CY5}

Amostras de RNA foram convertidas a cDNA e marcadas utilizando o Kit CyScribe Post-Labelling (GE Healthcare Buckinghamshire, UK) que envolve a preparação e adequação do cDNA em dois passos. No primeiro passo ocorre a síntese da primeira fita de cDNA com a incorporação de nucleotídeos amino- alil dUTP modificados, com posterior degradação da cadeia de RNAm e purificação do cDNA para remoção de nucleotídeos livres e oligômeros (figura 8). No segundo passo, o cDNA é marcado com formas reativas de ésteres NHS Cy3 e Cy5 que se ligam aos nucleotídeos modificados e após um processo de purificação para eliminação dos $C y D y e$ não incorporados a sonda está pronta para hibridação (figura 9). 


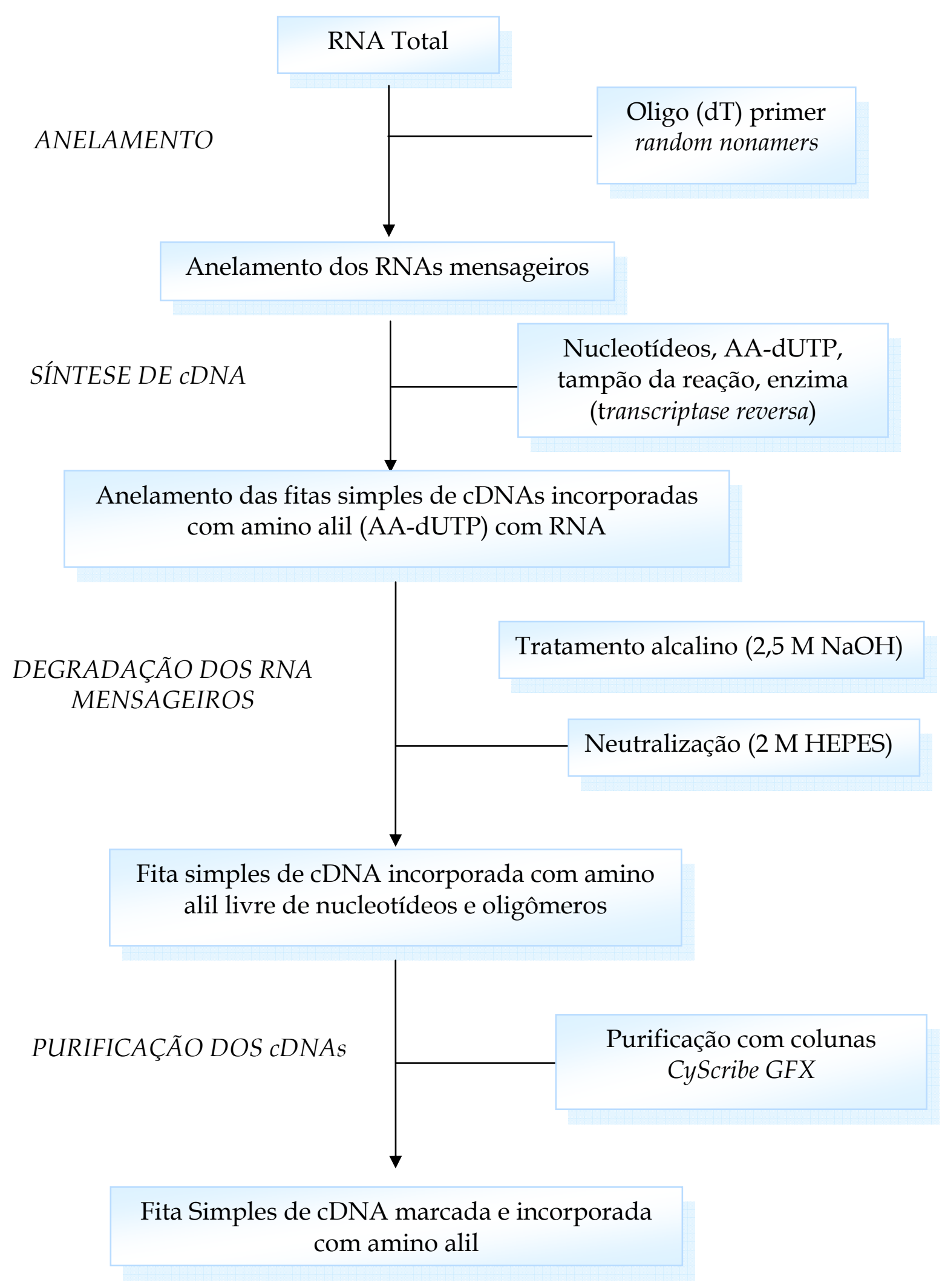

Figura 8. Preparação da fita simples de cDNA incorporada com amino alil usando os reagentes do kit "CyScribe Post Labelling"(GE Healthcare). 


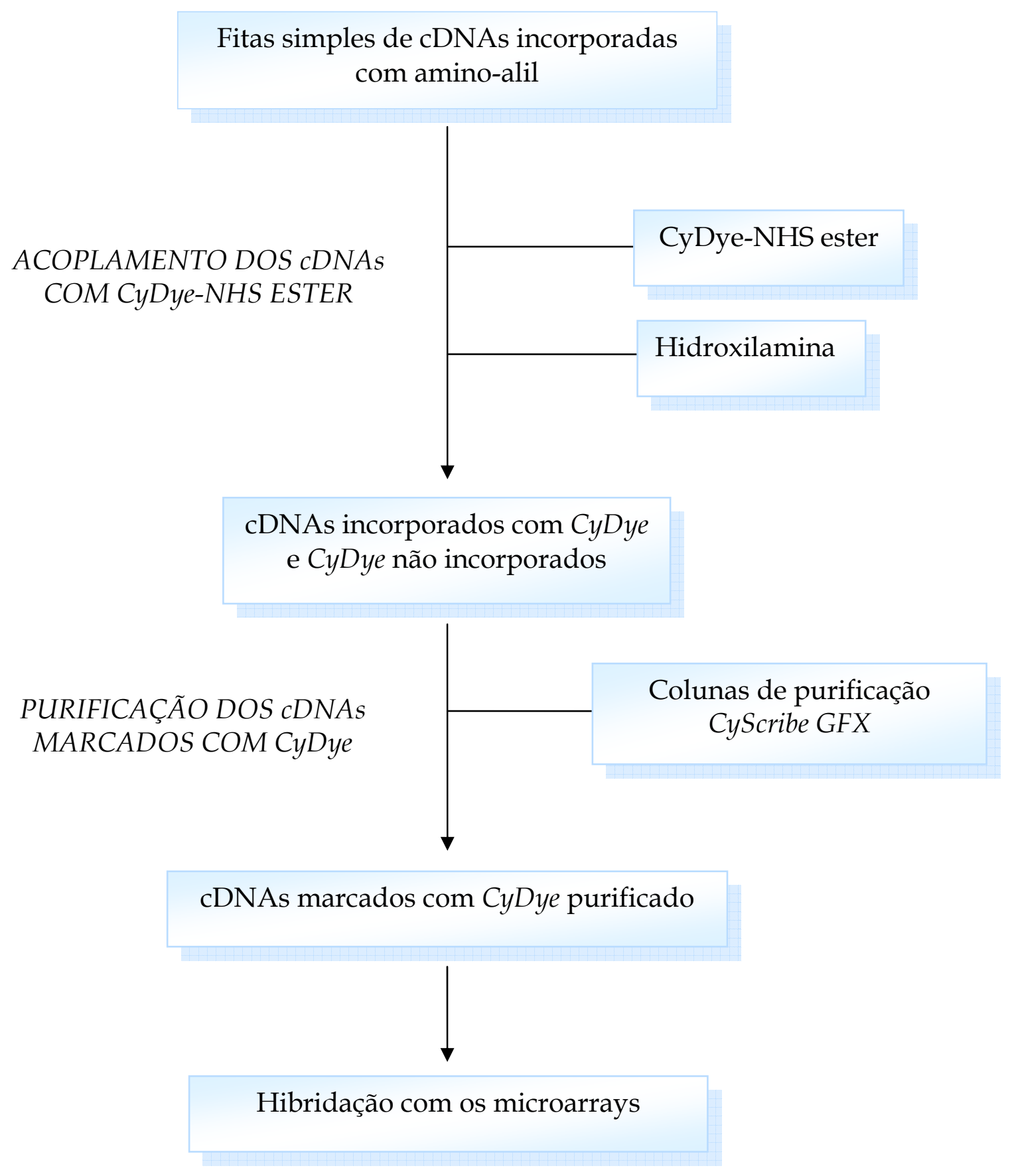

Figura 9. Preparação do cDNA marcado com CyDye utilisando os reagentes do kit "CyScribe Post Labelling" (GE Healthcare). 
a) Preparação da primeira fita de cDNA por incorporação de AAdUTP

Em um tubo Eppendorf de 1,5 $\mu \mathrm{l}$ imerso em gelo picado foram adicionados $10 \mu \mathrm{g}$ de RNA total, $1 \mu \mathrm{l}$ de primers randômicos, $3 \mu \mathrm{l}$ de oligo (dT) e $0,5 \mu l$ de controle denominado "spike mix" para o Universal ScoreCard em um volume total de $11 \mu$ (Proporção de $2 \mu \mathrm{l}$ de spike mix para cada $1 \mu \mathrm{g}$ de RNA marcado). A reação foi cuidadosamente montada e incubada a $70^{\circ} \mathrm{C}$ por $5 \mathrm{~min}$, sendo posteriormente resfriada a $4^{\circ} \mathrm{C}$ durante 5 min. A extensão da cadeia de cDNA foi realizada utilizando 4 $\mu 1$ de tampão 5X CyScript , $2 \mu 1$ de DDT 0,1 M, $1 \mu 1$ de nucleotídeo "mix", $1 \mu \mathrm{l}$ de AA-dUTP (a quantidade de um tubo contendo AA-dUTP liofilizado foi ressuspenso em $30 \mu \mathrm{l}$ de água livre de nucleases e mantido a $-20^{\circ} \mathrm{C}$ por no máximo 30 dias), $1 \mu \mathrm{l}$ de transcriptase reversa CyScript, em um volume final de reação de $20 \mu$ l. A reação foi incubada a $42^{\circ} \mathrm{C}$ por 1,5 hora. Procedemos à degradação do RNAm adicionando $2 \mu \mathrm{l}$ de NaOH 2.5 $\mathrm{M}$ com incubação a $37^{\circ} \mathrm{C}$ durante $15 \mathrm{~min}$, posteriormente foi adicionado $20 \mu 1$ de HEPES 2M.

b) Purificação do cDNA com colunas de purificação CyScribe GFX

Para cada amostra de cDNA com volume entre 20 a $100 \mu \mathrm{l}$ foram adicionados $500 \mu \mathrm{l}$ de solução "capture buffer" em uma coluna de purificação GFX colocada dentro de um tubo coletor. O produto de cDNA marcado com aminoalil não purificado foi adicionado à coluna e misturado 5 vezes. A centrifugação foi feita a 13800 xg por 30 seg. A coluna foi retirada e o líquido contido no tubo coletor foi descartado. A coluna foi novamente colocada no tubo coletor e foram adicionados $600 \mu \mathrm{l}$ de etanol $80 \%$. A centrifugação foi feita a 13800 xg por 30 seg. A coluna foi retirada e o líquido contido no tubo coletor foi descartado. Esta 
lavagem foi repetida mais duas vezes. Uma nova centrifugação foi feita a 13800 xg por 10 seg. para retirada do excesso de etanol $80 \%$ da amostra. O tubo coletor foi descartado e a coluna contendo o cDNA foi colocada em um tubo de 1,5 $\mu \mathrm{l}$. Foi adicionada a coluna $60 \mu \mathrm{l}$ de bicarbonato de sódio 0,1 M pH 9,0 e incubado durante 5 minutos. O material foi centrifugado a $13800 \mathrm{xg}$ por $1 \mathrm{~min}$.

c) Incorporação de Cy3 e Cy5

A amostra de cDNA marcada com aminoalil purificado foi adicionada a um tubo com a alíquota de CyDye NHS éster e ressuspendida várias vezes. O material foi centrifugado a $13800 \mathrm{xg}$ por 1 min e incubado, no escuro, durante 1 hora. Posteriormente, foi adicionado $15 \mu \mathrm{l}$ de hidroxilamina $4 \mathrm{M}$ seguida de incubação no escuro, durante $15 \mathrm{~min}$ a temperatura ambiente.

d) Purificação do cDNA marcado com CyDye com colunas de purificação CyScribe GFX

Para cada amostra de cDNA com volume entre 20 a $100 \mu \mathrm{l}$ foram adicionados $500 \mu \mathrm{l}$ de solução "capture buffer" em uma coluna de purificação GFX colocada dentro de um tubo coletor. O produto de cDNA marcado com CyDye não purificado foi adicionado à coluna e misturado 5 vezes. A centrifugação foi feita a 13800 xg por 30 segundos. A coluna foi retirada e o líquido contido no tubo coletor foi descartado. A coluna foi novamente colocada no tubo coletor e foram adicionados 600 $\mu \mathrm{l}$ da solução "wash buffer". A centrifugação foi feita a 13800 xg por 30 segundos. A coluna foi retirada e o líquido contido no tubo coletor foi descartado. Esta lavagem foi repetida mais duas vezes. Uma nova 
centrifugação foi feita a 13800 xg por 10 segundos para retirada do excesso da solução "wash buffer" da amostra. O tubo coletor foi descartado e a coluna contendo o cDNA foi colocada em um tubo de 1,5 $\mu$ l. Foi adicionado a coluna $60 \mu \mathrm{l}$ da solução "elution buffer" pré-aquecido à $65^{\circ} \mathrm{C}$ e incubado durante 5 minutos. $\mathrm{O}$ material foi centrifugado a 13800 xg por 1 minuto.

e) Quantificação do CyDye incorporado no cDNA

Após a purificação foi feita a monitoração de incorporação dos fluorocromos por meio de leitura em espectrômetro (Ultrospec 2100, GE Healthcare) em comprimento de onda a $550 \mathrm{~nm}$ para Cy3 e $650 \mathrm{~nm}$ para o Cy5 usando amostras diluídas 100X. A quantidade de Cy3 ou Cy5 incorporados no cDNA pode ser calculada através do seu coeficiente de extinção molar $1500001 \mathrm{~mol}^{-1} \mathrm{~cm}^{-1}$ para Cy3 e $2500001 \mathrm{~mol}^{-1} \mathrm{~cm}^{-1}$ para Cy5. As proporções de Cy3 e Cy5 incorporados no cDNA foram calculados pela fórmula: (A)/E x Z x fator de diluição $\times 10^{12}$, onde:

$$
\begin{aligned}
& A=\text { absorbância de Cy3 a } 550 \text { nm ou Cy5 a } 650 \mathrm{~nm} \\
& E=\text { coeficiente de extinção para Cy3 ou Cy5 } \times 10^{-6} \\
& Z=\text { volume }(\mu l) \text { da sonda após purificação }
\end{aligned}
$$

Para hibridações com os dois fluorocromos foram adicionados os cDNA marcado com Cy3 e Cy5 em um tubo de microcentrífuga protegido da luz. A solução de cDNA foi concentrada no aparelho "Speed Vacum". A seguir o cDNA foi dissolvido em $6 \mu$ de água livre de nuclease e desnaturado a $95^{\circ} \mathrm{C}$ por $2 \mathrm{~min}$. A solução foi imediatamente resfriada no gelo por 30 seg. A essa reação adicionamos 1,5 $\mu \mathrm{l}$ de A $_{80}$ $(1 \mathrm{mg} / \mathrm{ml})$ e incubamos a $75{ }^{\circ} \mathrm{C}$ por $45 \mathrm{~min}$, estando assim pronta para o 
processo de hibridação.

\subsection{Hibridação das lâminas de microarrays}

As lâminas de microarrays foram hibridadas utilizando um processador automático de lâminas, "Lucidea Automated Slide Processor"ASP (Amersham Biosciences) que permite a hibridação e lavagens de lâminas em câmaras independentes (12 lâminas por vez). Este aparelho inclui um software que automatiza a injeção de amostras líquidas e soluções de lavagens ou ar dentro das câmaras e possui parâmetros de controle de temperatura e velocidade de injeção e circulação destas soluções no interior das mesmas.

As lâminas foram hibridadas por 15 horas a $42^{\circ} \mathrm{C}$. As condições de lavagens foram: 1XSSC/0,2\%SDS ( 2 × $20 \mathrm{seg}$. à temperatura ambiente); 0,1X SSC /0,2\% SDS ( 2 x 20 seg. à temperatura ambiente); 0,1X SSC ( 2 × 20 seg. à temperatura ambiente). A última lavagem das lâminas foi feita com isopropanol, sendo em seguida aquecidas a $42^{\circ} \mathrm{C}$, e novamente lavagem com isopropanol. Após as lavagens as lâminas foram aquecidas a $60^{\circ} \mathrm{C}$ para secagem. As lâminas estavam prontas para serem "lidas" em aparelho "scanner" a laser.

\subsection{Aquisição de imagens de microarrays}

As lâminas foram lidas num aparelho Generation III "Array Scanner" (Amersham Biosciences) com lasers de 532nm para o Сy3 (verde) e $633 \mathrm{~nm}$ para o Cy5 (vermelho). A leitura da lâmina gera dois arquivos com imagens separadas com os pontos em preto para os dois 
canais (Сy3 e Сy5) e uma terceira imagem, agora colorida, sobrepondo Су3 e Cy5 visualizadas usando o software ImageQuant (GE Healthcare).

\subsection{Quantificação e normalização dos dados de microarrays}

Após obtenção das imagens seguiu-se à análise realizada em duas etapas.

- Inicialmente, os dados contidos nas imagens foram transformados em dados numéricos, utilizando o programa Spotfinder (http://www.tigr.org/software). Esse programa, além de transformar as informações das imagens em valores numéricos, também analisa a qualidade dos pontos e calcula o "background". Dois parâmetros foram considerados para o controle de qualidade neste programa: os pontos de boa qualidade apresentam valores superiores e/ou igual a 1 valor "backgrounds" mais 1 valor desvio padrão.

- Em seguida, estes dados foram normalizados. A normalização retira os erros experimentais sistemáticos por balancear a intensidade dos dois fluorocromos. Esses erros podem ocorrer devido à diferença de incorporação dos corantes, efeitos espaciais na lâmina e diferenças durante a aquisição das imagens nos dois canais. Para esses ajustes, utilizou-se a plataforma R (www.r-project.org), com o pacote AROMA (http://www.maths.lth.se/help/R/aroma/), que retém as funções necessárias para a normalização dos dados de microarrays. Portanto, após a retirada do background pelo programa Spotfinder, os dados foram importados para o ambiente $\mathrm{R}$ e transformados para o formato de dados "M versus $A$ ", onde $M$ é igual a $\log 2(R / G)$ e A é igual a 
1/2 $\log 2(R$ G). Em seguida, os métodos de normalização "print-tip Lowess" e "absolute median deviation (MAD) re-scaling" foram aplicados respectivamente. O primeiro método aplica uma regressão linear nos dados, para corrigir erros espaciais que possam ter sido gerados durante os experimentos. O segundo re-escalona as razões de log para cada microarray, de maneira que cada slide adquire a mesma distribuição dos dados, de acordo com a MAD, capaz de estimar com robustez a variância de uma amostra. Na figura 10, observamos o fluxograma da "pipeline" desenvolvida para análise dos dados.

Utilizando o pacote LIMMA (Linear Models for Microarray Data) (Smith, 2004) foi aplicado o método Bayesiano empírico para análise estatística da expressão diferencial. 


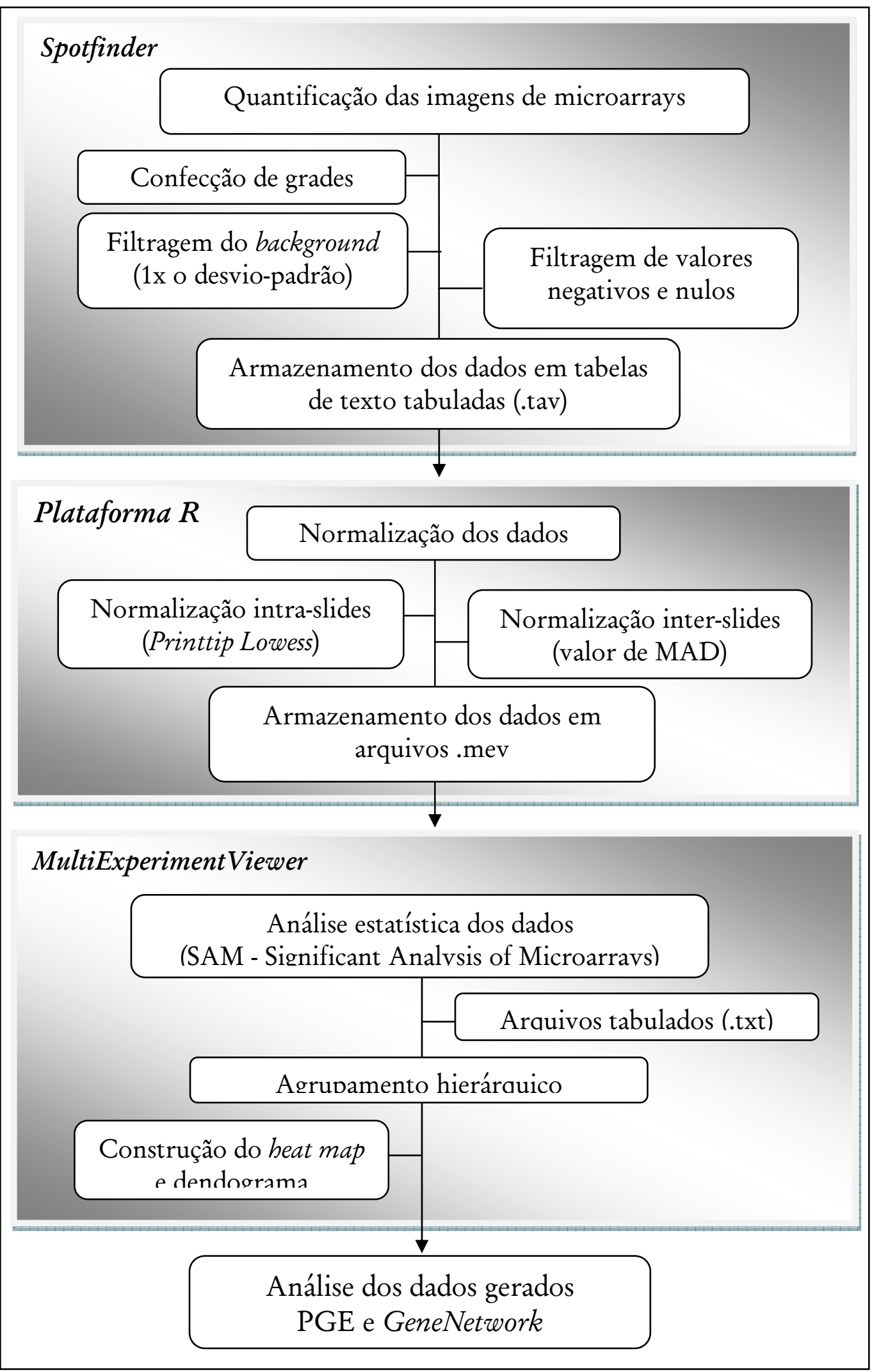

Figura 10. "Pipeline" utilizado na análise de dados de microarrays em lâminas de vidro. 
A plataforma $\mathrm{R}$ irá gerar arquivos de extensão .TAV.MOD.MEV que serão utilizados no programa TIGR MEV (The Institute for Genomic Research MultiExperiment Viewer) (http://www.tm4.org/mev.html) que inclui o programa SAM (Significance Analysis of Microarrays) (Tusher et al, 2001) utilizado para a detecção dos genes diferencialmente expressos (Smyth, 2004). O programa TIGR MEV gera um heat map (mapa de cores relacionado com o nível de expressão dos genes) para os valores. O heat map é composto por um código de cores a fim de facilitar a associação visual dos níveis de expressão gênica.

O programa SAM ("Significance Analysis of Microarrays”) representa uma evolução dos softwares de análise estatística para a tecnologia de microarrays e encontra-se disponível no endereço (http://www-stat.stanford.edu/ tibs/SAM/). A análise baseia-se em uma série de testes-t específicos para cada gene, que são adaptados para a detecção da expressão gênica diferencial em larga escala. A partir da observação de que as flutuações casuais são específicas para cada gene, o teste SAM é baseado na razão entre a diferença das médias das situações, como por exemplo, mTECs controles $\left(X_{c}\right)$ e mTEC em presença de RNAi anti-AIRE (Xp), e o desvio padrão de cada gene, calculados a partir de repetição experimental. A diferença relativa $\mathrm{d}(i)$ na expressão gênica é então definida pela equação 1:

[EQUAÇÃO]

$$
d(i)=\frac{X_{p}(i)-X_{c}(i)}{S(i)+S_{0}}
$$

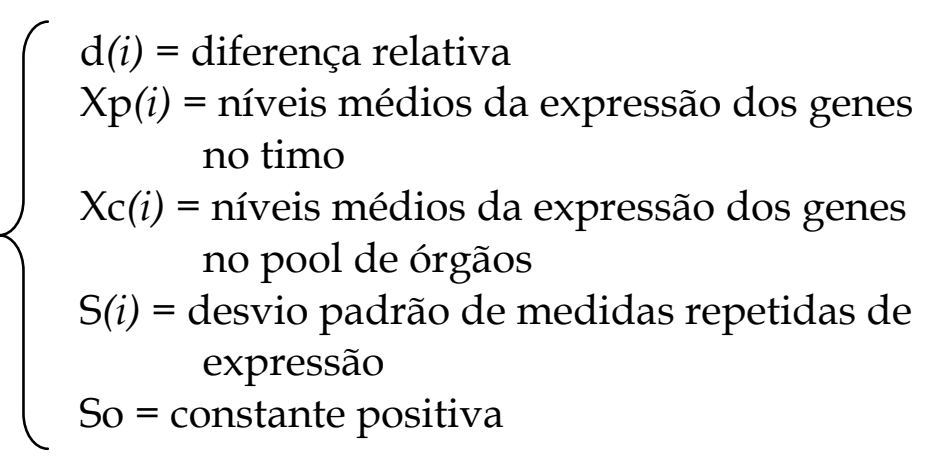


Onde $X_{p}(\mathrm{i})$ e $\mathrm{Xc}_{\mathrm{c}}(\mathrm{i})$ são definidos como níveis médios da expressão do gene nos estados p (timo) e c (pool de órgãos), respectivamente. A dispersão gene-específica S(i) é o desvio padrão de medidas repetidas de expressão, e a constante positiva So no denominador da equação acima, servem para certificação de que a variância de $d(i)$ é independente da expressão gênica. Para a determinação de genes com mudanças significativas na expressão, utilizou-se um gráfico de dispersão d(i), em relação à diferença relativa esperada $d_{E}$.(i). Para uma grande maioria de genes $d(i) \cong d_{E}(i)$, mas alguns genes são representados por pontos distantes da linha $\mathrm{d}(\mathrm{i}) \cong \mathrm{d}_{\mathrm{E}}$ (i). As alterações das expressões dos genes que se encontram a uma distância maior do que o limiar $(\Delta)$ é então considerado significante (figura 11).

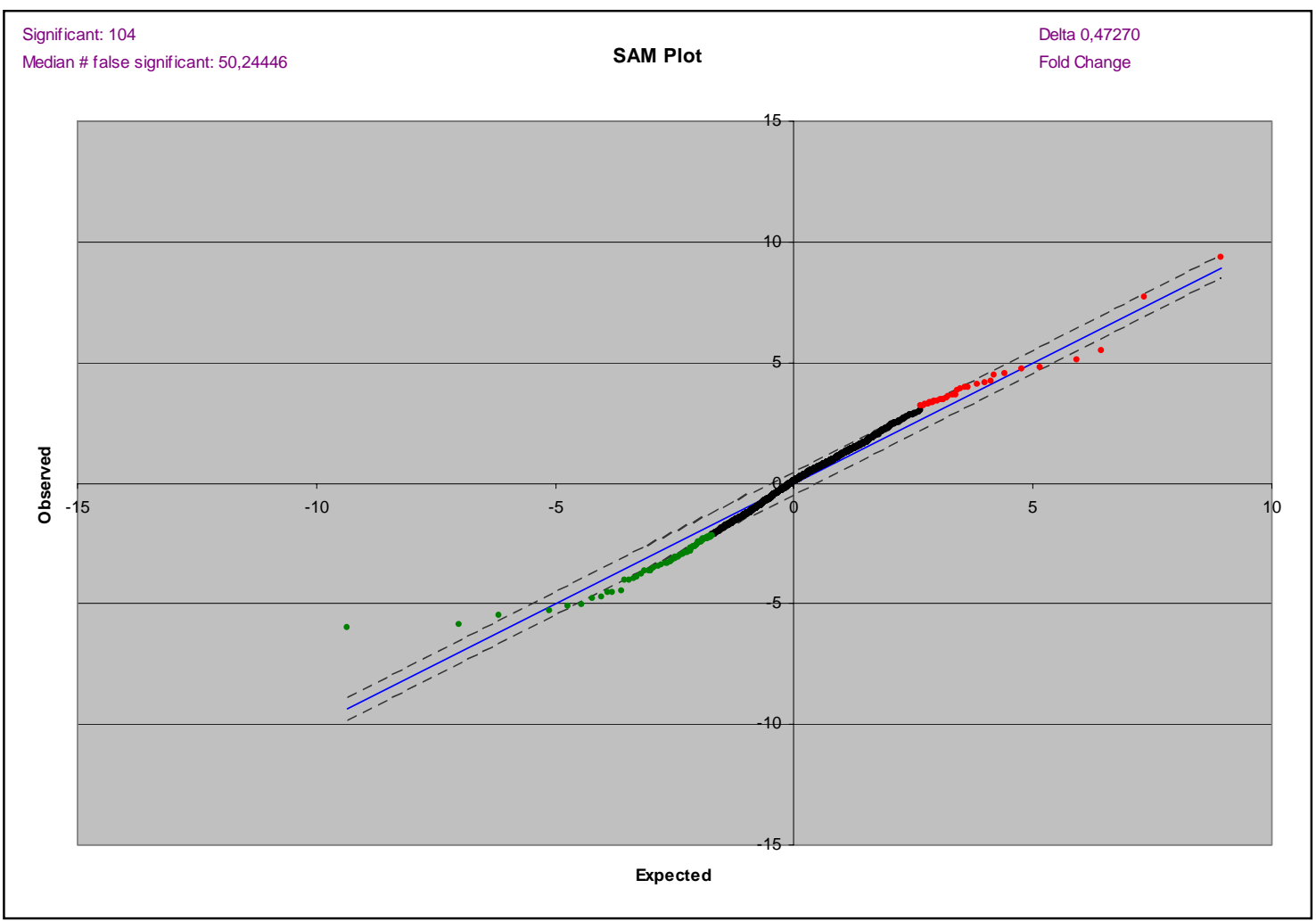

Figura 11: Comparação entre a distância relativa observada d(i) e esperada dE(i). 
O limiar $(\Delta)$ determina dois cortes horizontais, ou seja, o menor valor de $\mathrm{d}(\mathrm{i})$ indica que o gene seja considerado significantemente induzido (hiperexpresso), e o valor menos negativo de d(i) indica que o gene está significantemente reprimido (hipoexpresso).

A porcentagem de genes identificados por mudanças aleatórias é chamada de Frequiência de Descobertas Falsas (FDR), um método inicialmente idealizado por Benjamini \& Hochberg (1995) e definido como a proporção esperada de rejeições falsas. O cálculo de FDR e o número de genes com mudanças significativas estão intimamente relacionados com o limiar $\Delta$. À medida que o valor de $\Delta$ diminui, o número de genes significantemente alterados aumenta à custa de um aumento de um FDR. Essa determinação do nível de significância pelo limiar providencia cortes assimétricos para genes induzidos e genes reprimidos. Essa assimetria é desejável, posto que os genes induzidos e genes reprimidos podem se comportar de maneira diferente em alguns experimentos. Ao utilizar o SAM, o usuário pode escolher o limiar $\Delta$ mais conveniente com base no nível de significância estimado pelo FDR e no número de genes com os quais se pretende trabalhar.

O programa SAM estabelece automaticamente uma ligação entre o número de acesso das seqüências utilizadas com as páginas de informações sobre o clone em questão, situados no banco de dados S.O.U.R.C.E. ("Stanford Online Universal Resource for Clones and ESTs") (http:// source.stanford.edu/cgi-bin/source/sourceSearch).

S.O.U.R.C.E. compila informações de vários bancos de dados públicos (UniGene, dbEST, Swiss-Prot, GeneMap99, RHdb, GeneCards e LocusLink) e as disponibilizam de maneira a facilitar a identificação dos genes diferencialmente expressos. 
O programa SAM permite ainda o agrupamento hierárquico, porém, o mais importante na elaboração deste agrupamento é a decisão sobre qual medida de similaridade será adotada, a necessidade de se transformar a escala dos valores de expressão (normalmente transformada em escala logarítmica) e a dependência dos genes entre si. O agrupamento hierárquico nos permite a definição de grupos de genes com o mesmo padrão de expressão, seja ele de indução ou de repressão.

Todas as informações citadas acima foram retiradas do trabalho de Tusher et al. 2001, do manual do software SAM e de relatórios técnicos publicados na página de Robert Tibshirani (http://wwwstat.stanford.edu/ tibs/SAM).

\subsubsection{Nomenclatura dos genes}

Neste trabalho, optou-se por seguir a nomenclatura usual para genes de camundongos, ou seja, o símbolo do gene em inglês com a primeira letra maiúscula e as seguintes minúsculas (exemplo: Aire para Autoimmune regulator). Os nomes dos genes estão em inglês, pois toda a literatura e os bancos de dados internacionais como Source, GenBank etc. estão neste idioma. Além disso, todos os arquivos da biblioteca de cDNA estão em inglês.

\subsection{Análise da expressão gênica promíscua}

Os agrupamentos gênicos gerados durante o processamento dos dados no programa TIGR MEV foram analisados em termos de Expressão Gênica Promíscua (PGE) para avaliar a representatividade dos órgãos e 
sistemas. A análise foi feita utilizando o banco de dados SymAtlas (http://symatlas.gnf.org/SymAtlas/) que permite a visualização da expressividade de cada gene em um gráfico de barras paralelas que apresenta 60 tecidos, que representam por sua vez 17 sistemas do organismo.

Visando a homogeneização dos dados optou-se por considerar como tecidos representados por um determinado gene, apenas aqueles tecidos que obtiveram expressividade superior à linha da mediana que se encontra presente em cada gráfico. Após a organização dos dados em sistemas, gerou-se uma planilha contendo o número de genes que caracterizavam cada sistema em particular e, posteriormente, gerou-se um gráfico de setores demonstrando a representatividade de cada sistema nos agrupamentos definidos.

\subsection{GeneNetwork}

O programa escolhido para a inferência de redes gênicas foi o GeneNetwork por ser aquele que melhor se aplica aos nossos conjuntos de dados. O GeneNetwork é um software livre e encontra-se disponível aos usuários no site: http://genenetwork.sbl.bc.sinica.edu.tw/index.asp.

O fluxo do trabalho para GeneNetwork é como segue: (1) input dos dados experimentais no formato de texto limitado por tabulações; (2) procede a interpolação dos dados através do controlador de interpolação se o número de pontos de dados experimentais forem insuficientes para iniciar os cálculos de inferência; (3) executar a aproximação da inferência por engenharia reversa através do "Modeling controller" para gerar a matriz gênica regulatória que descreve como os genes se regulam; (4) 
extrair automaticamente a rede para a visualização, baseada na matriz regulatória; (5) comparar a rede intuitiva inferida com as bases de dados on-line tais como KEGG (http://www.genome.jp/kegg/), baseado na informação do GraphViewer Network e do Information Viewer; e (6) a revisão dos conjuntos de experiências propostos e geração da hipótese (Wu et al., 2004).

Para facilitar a interpretação dos grafos gerados pelo programa GeneNetwork um dos alunos de mestrado do nosso laboratório, Guilherme Silva Liberato desenvolveu o programa Mandala, ainda não publicado. Seu algoritmo, escrito em linguagem de programação C, decodifica a matriz regulatória proveniente do GeneNetwork, desvendando as interações gênicas existentes sem que seja necessário analisar o grafo correspondente à rede. O resultado é apresentado em formato textual. 
DELINEAMENTO EXPERIMENTAL 


\section{DELINEAMENTO EXPERIMENTAL}

\section{Cultura de células mTECs na presença ou não de RNAi.}

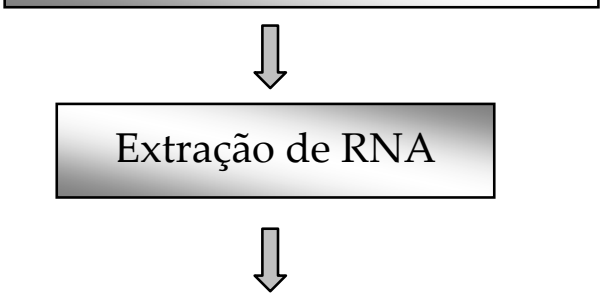

\section{Biblioteca de cDNA}

IMAGE.

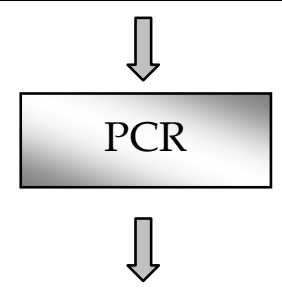

Confecção de cDNA-microarrays em lâminas de vidro com o auxílio do robô Array Spotter Gen III (GE).

Hibridações

$\prod$

Quantificação das imagens com o uso do programa SpotFinder.

$\sqrt{3}$

Análise dos dados realizada no ambiente estatístico $R$ com o auxílio dos pacotes LIMMA, Bioconductor, Aroma e KTH.

$$
\sqrt{ }
$$

Identificação dos genes diferencialmente expressos.<smiles>[CH]=C</smiles>

Análises "in silico" (SymAtlas, GeneNetwork, Mandala).

Figura 12. Fluxograma do trabalho mostrando o sistema modelo experimental utilizando células tímicas epiteliais medulares (mTEC 3.10), a inibição do transcrito do gene Aire, as hibridações com microarrays e o uso dos programas de bioinformática. 
Resultados 


\section{RESULTADOS}

6.1. Inibição seletiva do transcrito do gene Aire com RNA interferente (RNAi).

O ensaio de silenciamento do transcrito do gene Aire foi realizado usando a seqüência que apresentou melhor eficiência do Kit TriFECTa ${ }^{\mathrm{TM}}$ (IDT - Integrated DNA Tecnologies, USA).

Como já explicado em Material e Métodos, além das seqüências anti-Aire, outras três seqüências que estavam incluídas no kit foram utilizadas: 1) RNAi irrelevante marcado com Cy3 usado para medir a eficiência de transfecção (microscopia de fluorescência), 2) uma seqüência duplex de RNAi irrelevante, o qual não é capaz de alterar a expressão gênica nas células em estudo e 3) um controle positivo, constituída de uma sequiência RNAi anti-HPRT (hypoxanthine guanine phosphoribosyl transferase), um gene constitutivo, utilizada para avaliar se o processo de transfecção e o sistema modelo são adequados para inibição com RNAi.

6.1.1. Monitoramento da transfecção e determinação da seqüência de RNAi anti-Aire.

Para o monitoramento do método de transfecção foi realizada uma cultura em presença de RNAi irrelevante marcado com Cy3. Como é possível observar na figura 13, o método de transfecção por lipofectamina (Hiperfect Transfection Reagent ${ }^{\circledR}$ da Qiagen) é adequado à transfecção de células mTEC 3.10 em cultura como observado por microscopia de 
fluorescência. Os pontos em vermelho brilhante correspondem às moléculas de RNA no interior da célula.

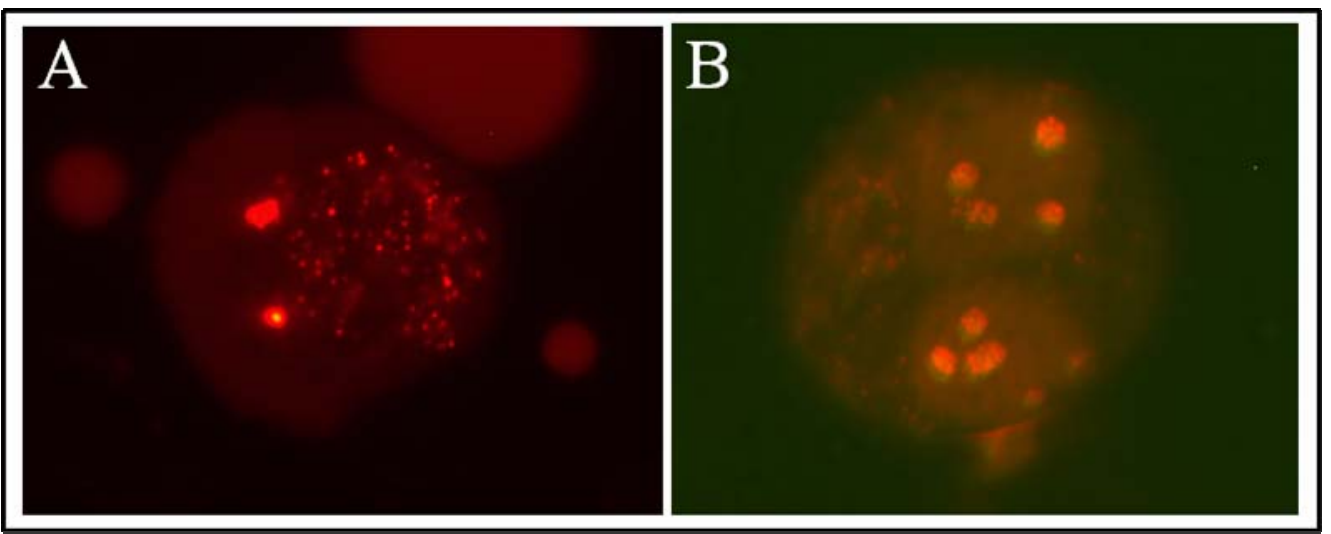

Figura 13. Células mTEC 3.10 após 24 h em cultura em presença de RNAi irrelevante marcado com Cy3. Visualização por microscopia de fluorescência (aumento 20x).

O resultado do silenciamento foi mensurado por meio de rt-PCR semiquantitativa (figura 15) e a seqüência 1 (figura 14) na concentração de $5 \mathrm{hM}$ foi a que apresentou um melhor resultado.

\section{5' rGrGrArUrUrCrUrCrUrUrUrArArGrGrArCrUrArCrArArU C T

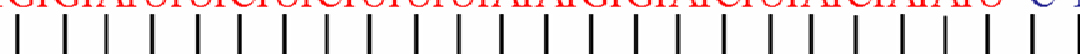 rCrUrCrCrUrArArGrArGrArArArUrUrCrCrUrGrArUrGrUrUrArGrA}

Figura 14. Sequência do RNA interferente para o transcrito do gene Aire, selecionada para a realização do trabalho. 


\section{PCR semiquantitativa gene Aire}

$\begin{array}{lllllllll}1: 1 & 1: 2 & 1: 4 & 1: 8 & 1: 16 & 1: 32 & 1: 64 & 1: 128 & \text { B }\end{array}$

mTEC

RNAi 1 2,5nM

* RNAi 1 5,0nM

RNAi 1 10nM

RNAi 2 2,5nM

RNAi 2 5,0nM

RNAi 2 10nM

RNAi 3 2,5nM

RNAi 3 5,0nM

RNAi 3 10nM

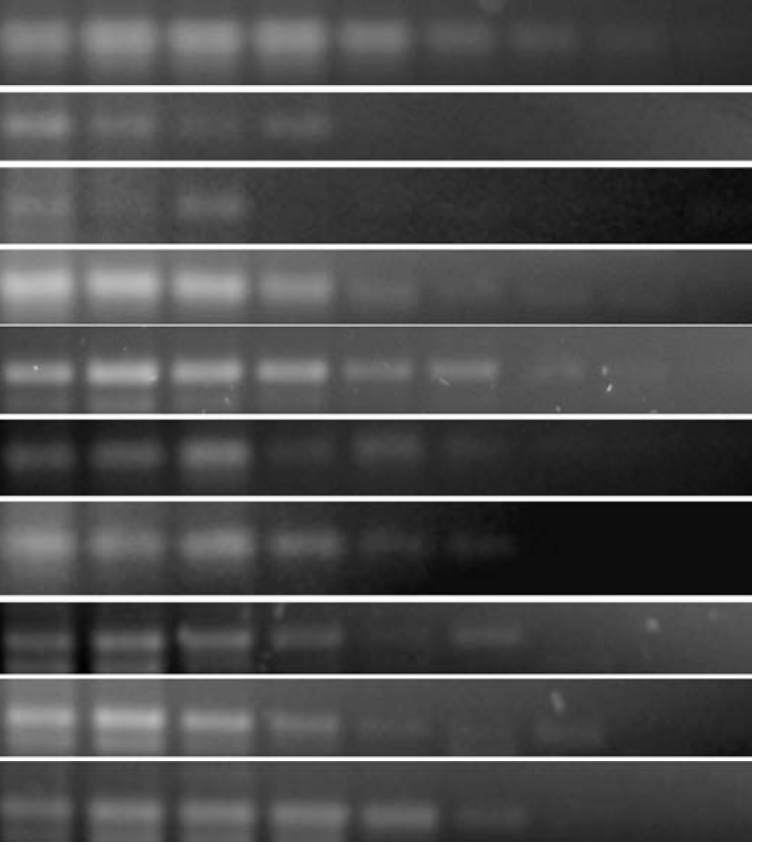

Figura 15. Eletroforese em gel de agarose de produtos de rt-PCR semiquantitativa para a detecção do transcrito do gene Aire. PCRs realizadas com as seguintes amostras: mTEC na ausência de RNA interferente e mTEC em presença das três diferentes seqüências de RNAi anti-Aire, cada uma em três concentrações (2.5, 5.0 e $10.0 \mathrm{nM})$. * RNAi e concentração escolhidos para a continuação dos experimentos.

\subsection{Avaliação da integridade do RNA total}

\subsubsection{Amostras utilizadas como "pool" de referência.}

A qualidade das amostras de RNA total proveniente de diferentes timos de camundongos C57Bl/ 6 adultos foi avaliada por eletroforese em gel de agarose 1\% em condições denaturantes. As amostras que se apresentaram íntegras com relação às subunidades de RNAr 28S, 18S e 5S e RNAt, além das avaliações espectrofotométricas, foram selecionadas para compor o pool de referência (figura 16). 


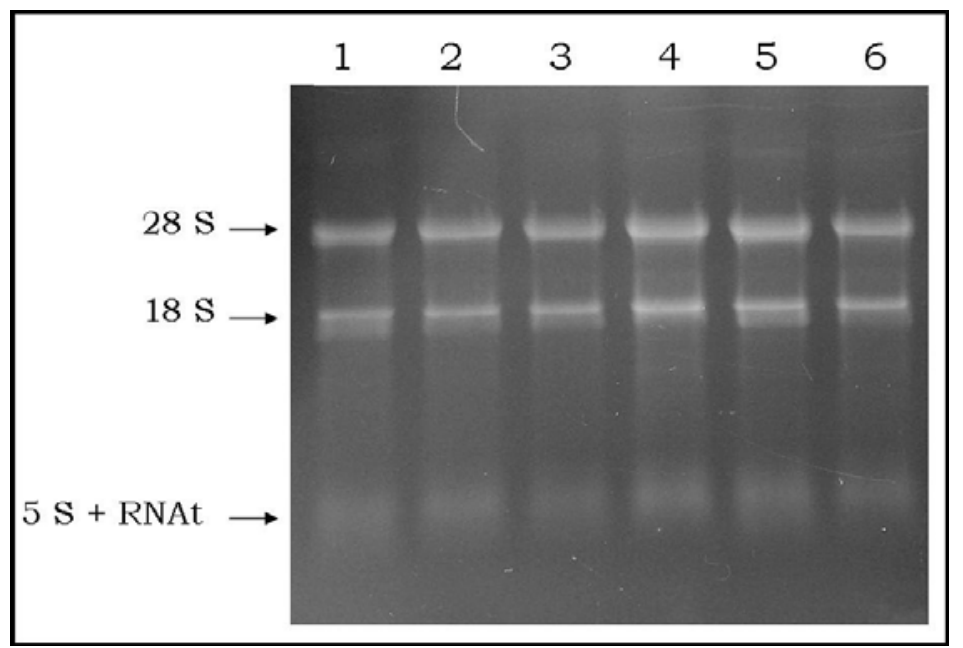

Figura 16. Eletroforese em gel de agarose de seis amostras de RNA total provenientes de timos de camundongos C57Bl/ 6 adultos.

\subsubsection{RNA total de Amostras de células mTEC.}

Assim como para as amostras de RNA total proveniente de timos as amostras de RNA total de células mTEC também foram submetidas à avaliação em gel de agarose 1\% em condições denaturantes. As amostras que se apresentaram íntegras com relação às subunidades $28 S, 18 S$ e $5 S$ e RNAt além das avaliações espectrofotométricas, foram selecionadas para marcação fluorescente (figura 17).

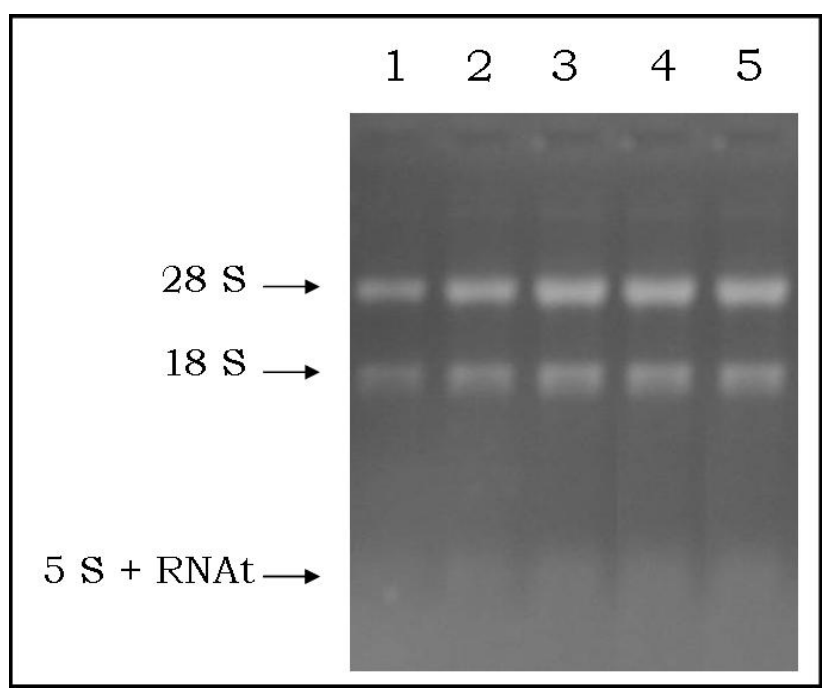

Figura 17. Eletroforese em gel de agarose de amostras de RNA total provenientes de células mTEC nas diferentes situações: 1) mTEC; 2) mTEC + lipofectamina; 3) mTEC + RNAi irrelevante; 4) mTEC + RNAi anti-HPRT; 5) mTEC + RNAi anti-Aire). 


\subsection{RT-PCRs semi-quantitativas para os transcritos dos genes Aire e HPRT.}

Para avaliar o silenciamento dos transcritos dos genes Aire e HPRT foram realizadas duas rt-PCRs semi-quantitativas, uma para o transcrito HPRT (figura 18), um gene constitutivo contra o qual também foi usado um RNA interferente e outra para o próprio transcrito do gene Aire (figura 19). É possível observar que o silenciamento de ambos os transcritos foi parcial, pois ainda foi possível detectar seus respectivos transcritos, embora em menor concentração em relação aos respectivos controles $(* ; * *)$.

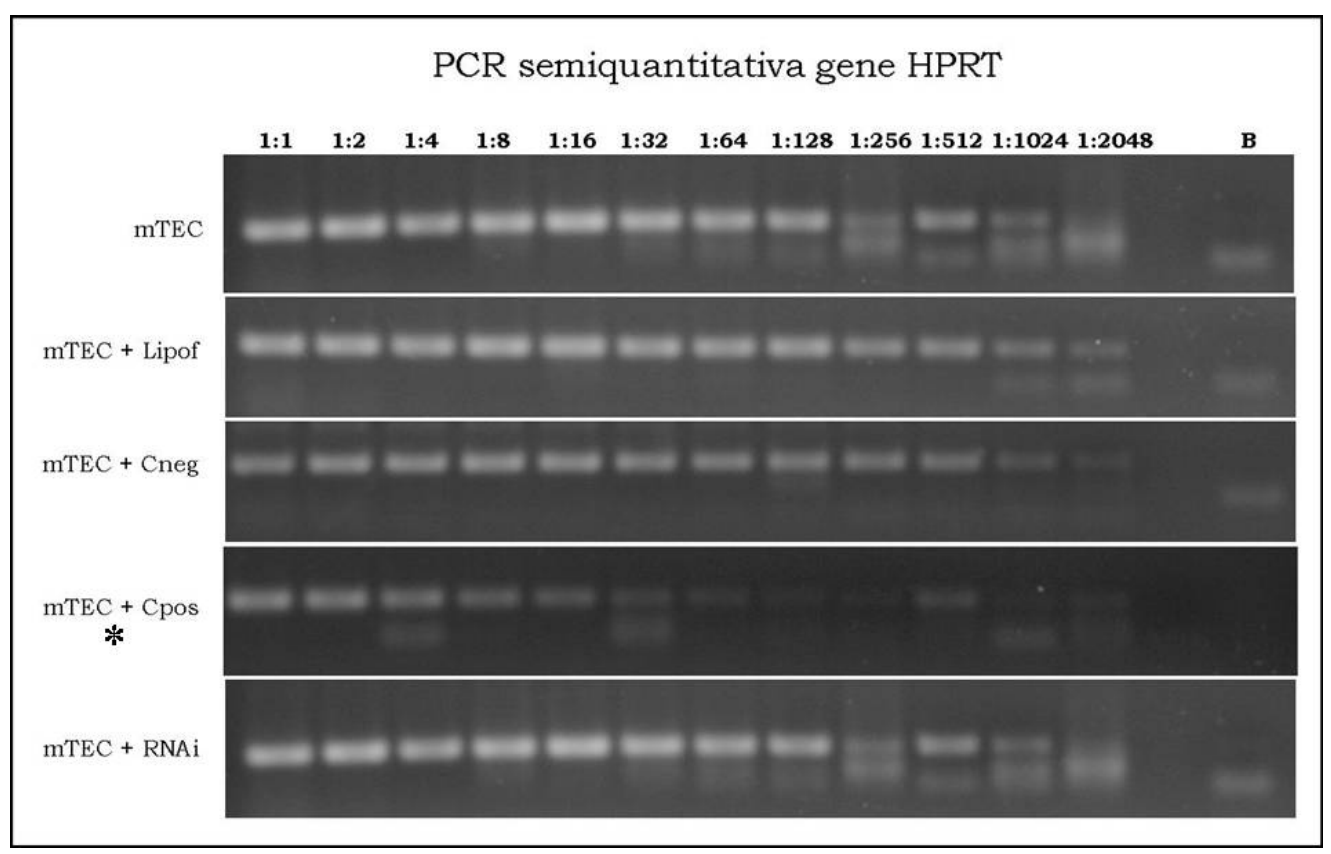

Figura 18. Eletroforese de produtos de rt-PCR semiquantitativa para o gene HPRT realizada com as seguintes amostras: $\mathrm{mTEC}$; mTEC + lipofectamina; mTEC + RNAi irrelevante (Cneg); mTEC + RNAi anti-HPRT (Cpos); mTEC + RNAi anti-Aire (RNAi). * É possível observar uma diminuição do gene HPRT na amostra submetida à presença de RNAi anti-HPRT. 


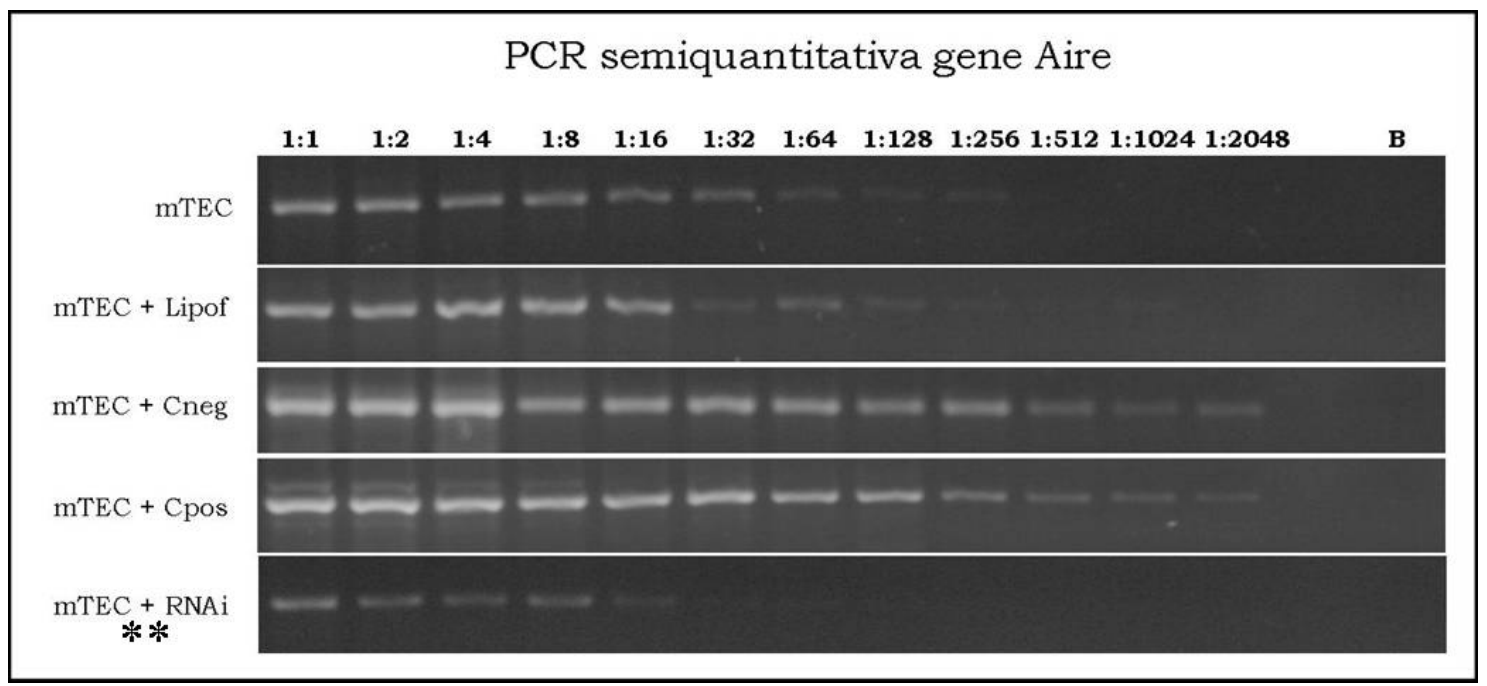

Figura 19. Eletroforese de produtos de rt-PCR semiquantitativa para o gene Aire realizada com as seguintes amostras: mTEC; mTEC + lipofectamina; mTEC + RNAi irrelevante (Cneg); mTEC + RNAi anti-HPRT (Cpos); mTEC + RNAi anti-Aire (RNAi). ** É possível observar uma diminuição maior do gene Aire na amostra submetida à presença de RNAi anti-Aire.

\subsection{Amplificação de cDNA para a confecção de microarrays}

A primeira etapa para a construção dos microarrays consistiu na amplificação por PCR dos insertos de cDNA (biblioteca IMAGE) diretamente dos clones em cultura bacteriana.

Dos 624 clones selecionados da biblioteca murina e humana, $82,5 \%$ foram corretamente amplificados (uma única banda em gel), 6,5\% não amplificaram e 11\% apresentaram bandas múltiplas (Figura 20). O resultado típico destas amplificações pode ser observado na figura 21.

O microarray utilizado neste trabalho foi preparado com seqüências de cDNA de genes cujas funções são relacionadas ao sistema imune e também algumas ESTs (Expressed Sequence Tags) com função desconhecida. 


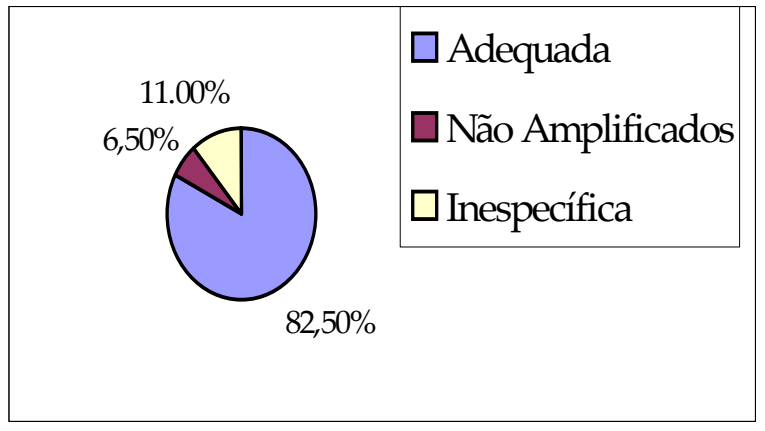

Figura 20. Eficiência das amplificações por PCR dos clones de cDNA IMAGE utilizados no preparo do microarray.

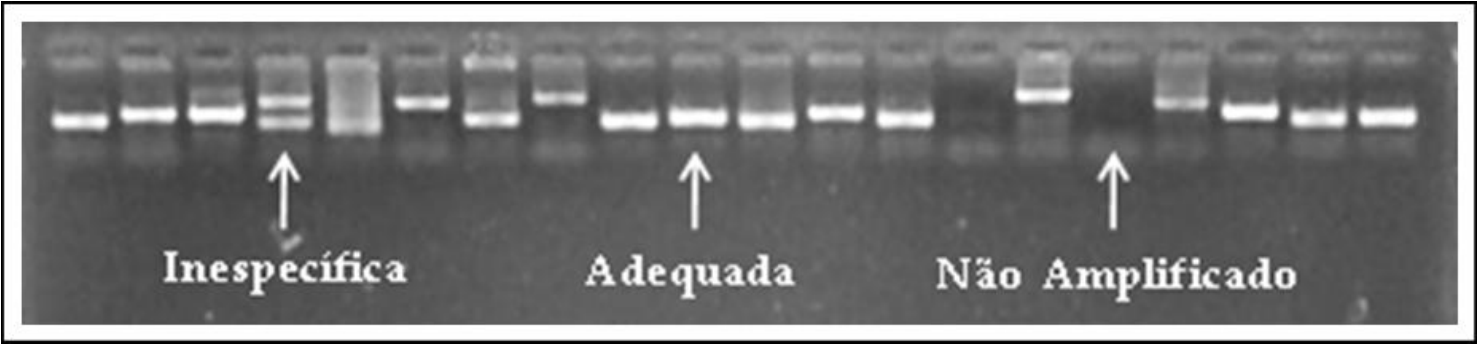

Figura 21. Eletroforese em gel de agarose $1 \%$ dos produtos de PCR de alguns clones da biblioteca de cDNA IMAGE.

\subsection{Aquisição de imagens de microarrays}

A figura 22 ilustra uma imagem típica de hibridação de uma das lâminas microarray em vidro. Neste caso utilizamos sonda complexa marcada com Cy3 (células mTEC em diferentes situações) e o pool de referência (timo) foi marcado com Cy5. Os pontos vermelhos correspondem aos genes expressos no pool de referência, enquanto que os pontos verdes correspondem aos genes expressos somente nas células mTEC e os pontos amarelos correspondem aos genes expressos em ambos. 


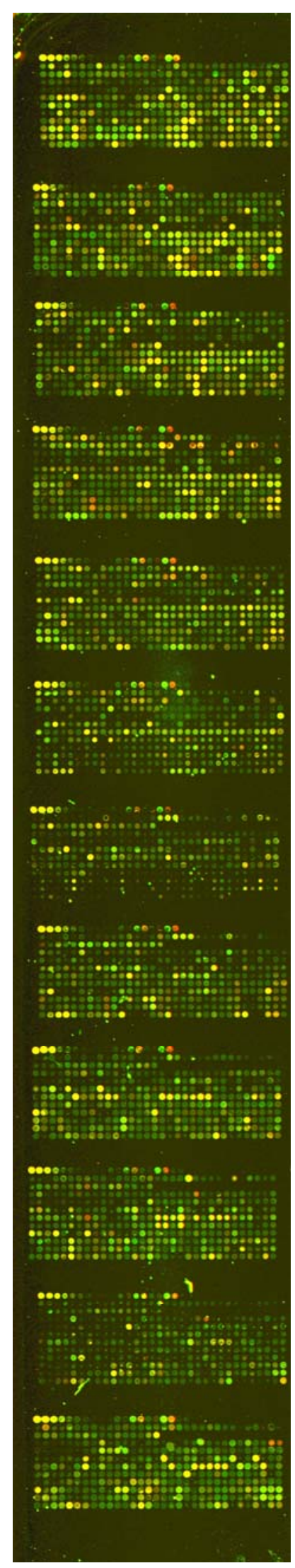

Figura 22. Imagem típica de hibridização de microarray com sondas fluorescentes (Cy3 e Cy5). 


\subsection{Quantificação e normalização dos dados de microarrays}

Para análise dos dados dos microarrays em lâminas de vidro contendo 4.500 seqüências, foi utilizado inicialmente o tratamento estatístico SAM (Significance Analysis of Microarrays) com o qual se pode selecionar 1611 genes diferencialmente expressos (FDR $\leq 5 \%$, p-value $\leq$ 0,005), ou seja, com 95\% de confiabilidade entre os cinco grupos de células analisadas. A figura 23 ilustra a matriz de expressão gênica com o dendrograma dos genes e amostras, com uma distinção entre os grupos amostrais de acordo com o tratamento. Os 1611 genes diferencialmente expressos estão listados na tabela II, do anexo I. 


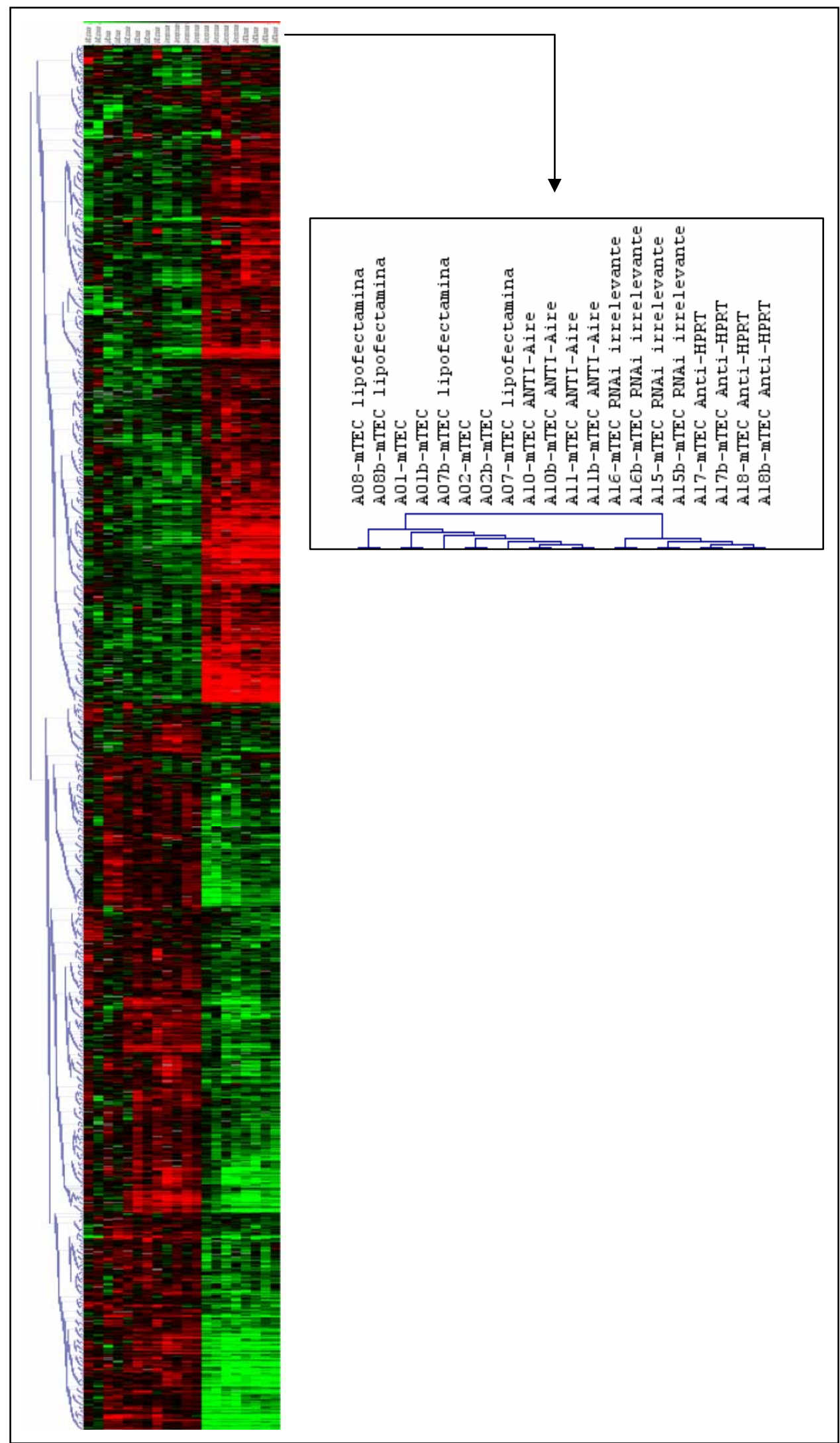

Figura 23. Agrupamento hierárquico mostrando o perfil de expressão gênica dos diferentes grupos de células mTEC. O agrupamento foi realizado utilizando correlação de Pearson e "average linkage" utilizando o programa TIGR MEV (http://www.tm4.org/mev.html). Verde representa genes reprimidos, vermelho genes induzidos, preto genes que não tiveram modulação com relação ao controle e cinza dados perdidos. 
Para um melhor entendimento do que ocorre com a expressão gênica das células mTEC em presença de um RNA interferente para o transcrito do gene Aire, foi realizada uma nova análise, considerando apenas as amostras mTEC e mTEC transfectadas com RNAi anti-Aire.

A estatística SAM selecionou 212 genes diferencialmente expressos (FDR $\leq 15 \%$, p-value $\leq 0,015$ ), ou seja, com $85 \%$ de confiabilidade. A figura 24 mostra um gráfico de dispersão gene-específico. A lista dos 212 genes diferencialmente expressos encontra-se na tabela III, do anexo II.

Dessa forma foi possível a elaboração de um heat map com os genes induzidos e reprimidos sob a influência de RNAi anti-Aire, gerando dendrogramas tanto dos genes quanto das amostras (figura 25). 


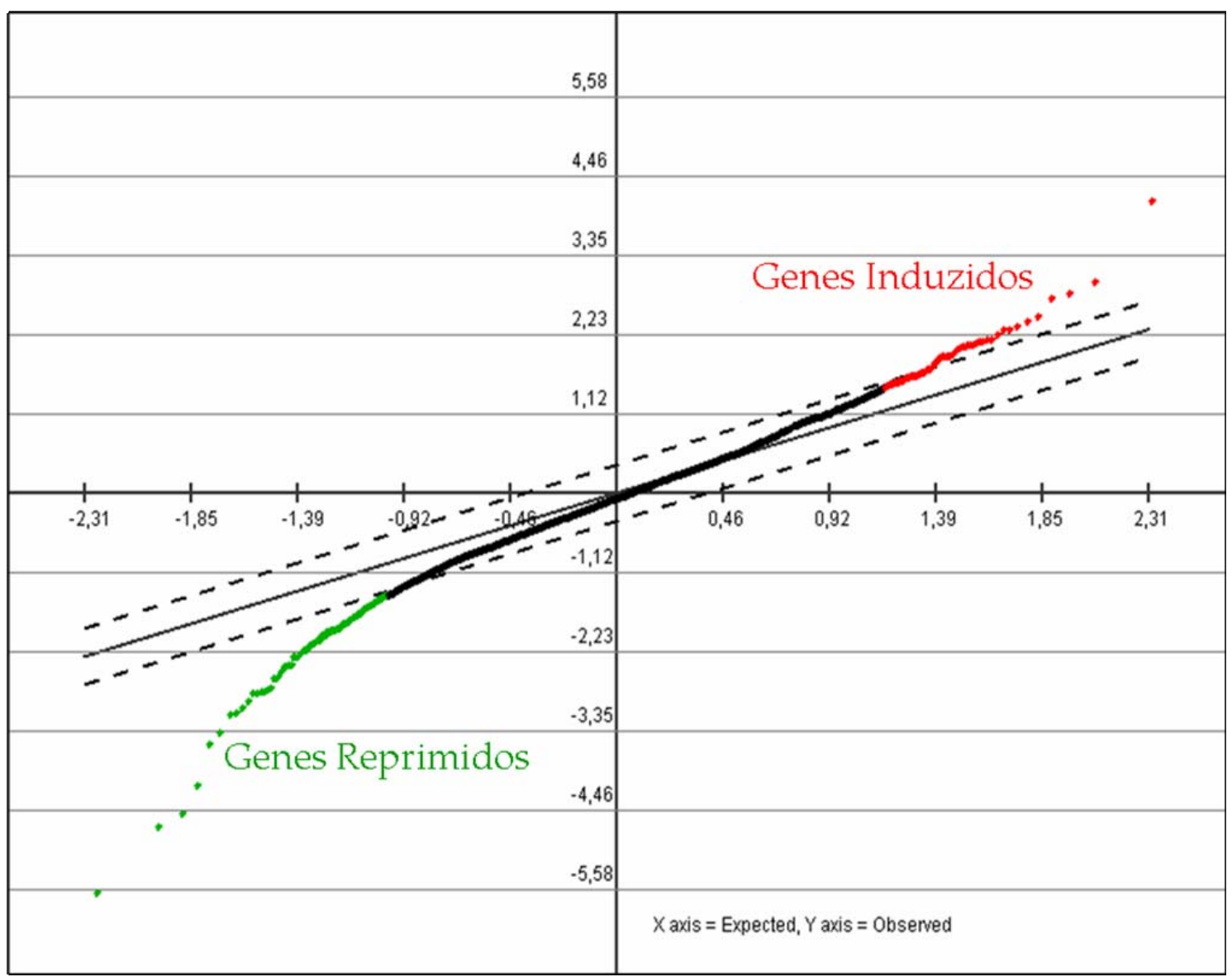

Figura 24. Genes diferencialmente expressos em células mTEC 42 horas após a inibição do transcrito do gene Aire. Significância com base estatística no programa SAM. Comparação entre a distância relativa observada d(i) e esperada $\mathrm{d}_{\mathrm{E}}(\mathrm{i})$. A linha contínua é a região onde $\mathrm{d}(\mathrm{i})=\mathrm{d}_{\mathrm{E}}(\mathrm{i})$. As linhas tracejadas são cortes a uma distância $\Delta$ da linha contínua. Os pontos vermelhos são genes que se afastaram da linha $d(i)=d_{E}(i)$, a uma distância $>\Delta$, sendo considerados induzidos e os pontos verdes são genes que se afastaram da linha $d(i)=d_{E}(i)$, a uma distância $<\Delta$, sendo considerados reprimidos. 


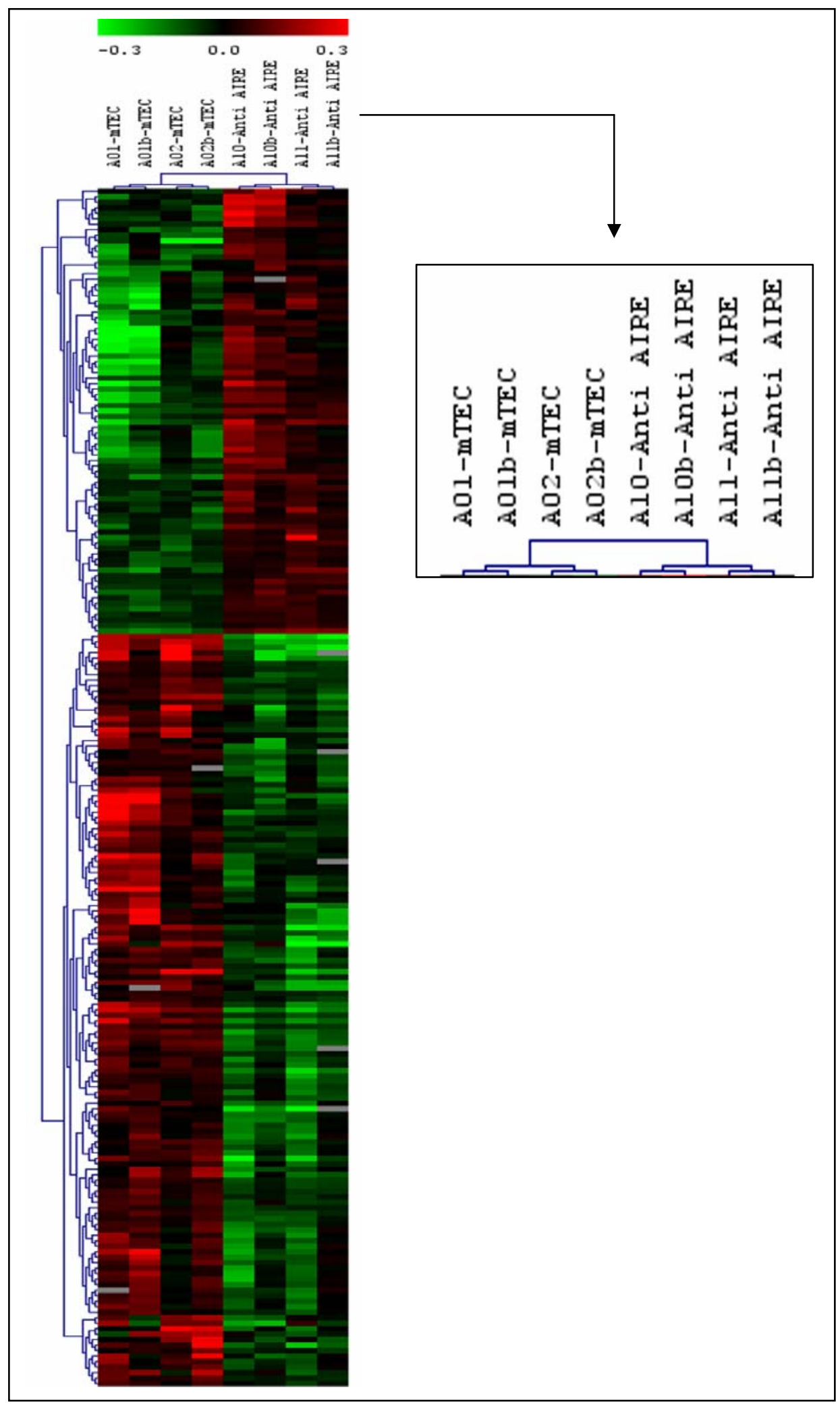

Figura 25. Agrupamento hierárquico mostrando o perfil de expressão gênica de células mTEC transfectadas com RNAi anti-Aire comparados ao grupo controle de células mTEC na ausência de qualquer tipo de RNA interferente. O agrupamento foi realizado utilizando correlação de Pearson e "average linkage" utilizando o programa TIGR MEV (http://www.tm4.org/mev.html). Verde representa genes reprimidos, vermelho genes induzidos, preto genes que não tiveram modulação com relação ao controle e cinza dados perdidos. 


\subsection{Análise da expressão gênica promíscua.}

A PGE exibida pelas células mTEC controles e transfectadas com o RNAi anti-Aire foi analisada a partir dos genes diferencialmente expressos obtidos pelo programa SAM seguida de agrupamento hierárquico. Dos 212 genes diferencialmente expressos, 80 encontravamse induzidos e 132 reprimidos em células mTEC transfectadas. Foi feita então uma consulta para cada um dos genes usando o banco de dados Symatlas (http://symatlas.gnf.org/SymAtlas/) que indica a representatividade do gene consultado em mais de 60 tecidos e/ou órgãos do camundongo (figura 26) os quais foram finalmente agrupados em 17 sistemas. As informações de cada gene encontrado no Symatlas possibilitaram a construção de gráficos de setores mostrando as porcentagens de representação dos 17 sistemas diferentes pelas células mTEC (figuras 27 e 28).

Como se pôde observar o silenciamento parcial de Aire desencadeou indução de vários genes e repressão de outros nas células mTEC, modulando assim os níveis de expressão dos genes TRAs (PGE) (figura 25). Esses dois conjuntos de genes serviram de base para se confeccionar dois gráficos de setores mostrando a modulação da PGE e, portanto, a modulação da representatividade de TRAs (figuras 27 e 28).

É importante salientar que a inibição parcial de Aire não alterou a diversidade deste conjunto gênico, mas sim seus respectivos níveis de expressão. 


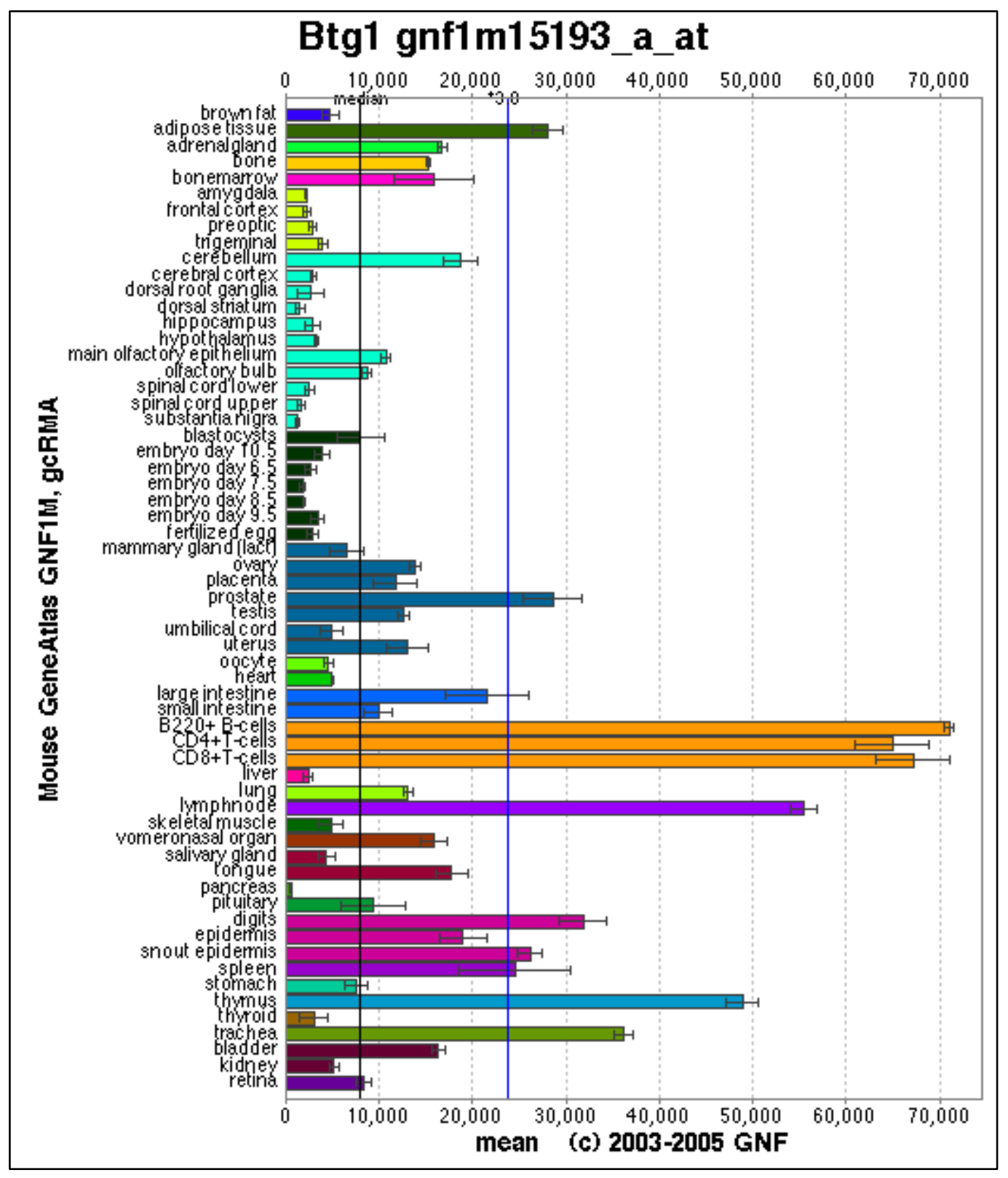

Figura 26. Gráfico ilustrativo gerado pelo banco de dados Symatlas (http://symatlas.gnf.org/SymAtlas/) mostrando a representação tecidual do gene Btg1, com os nomes de cada tecido e/ou órgão. 


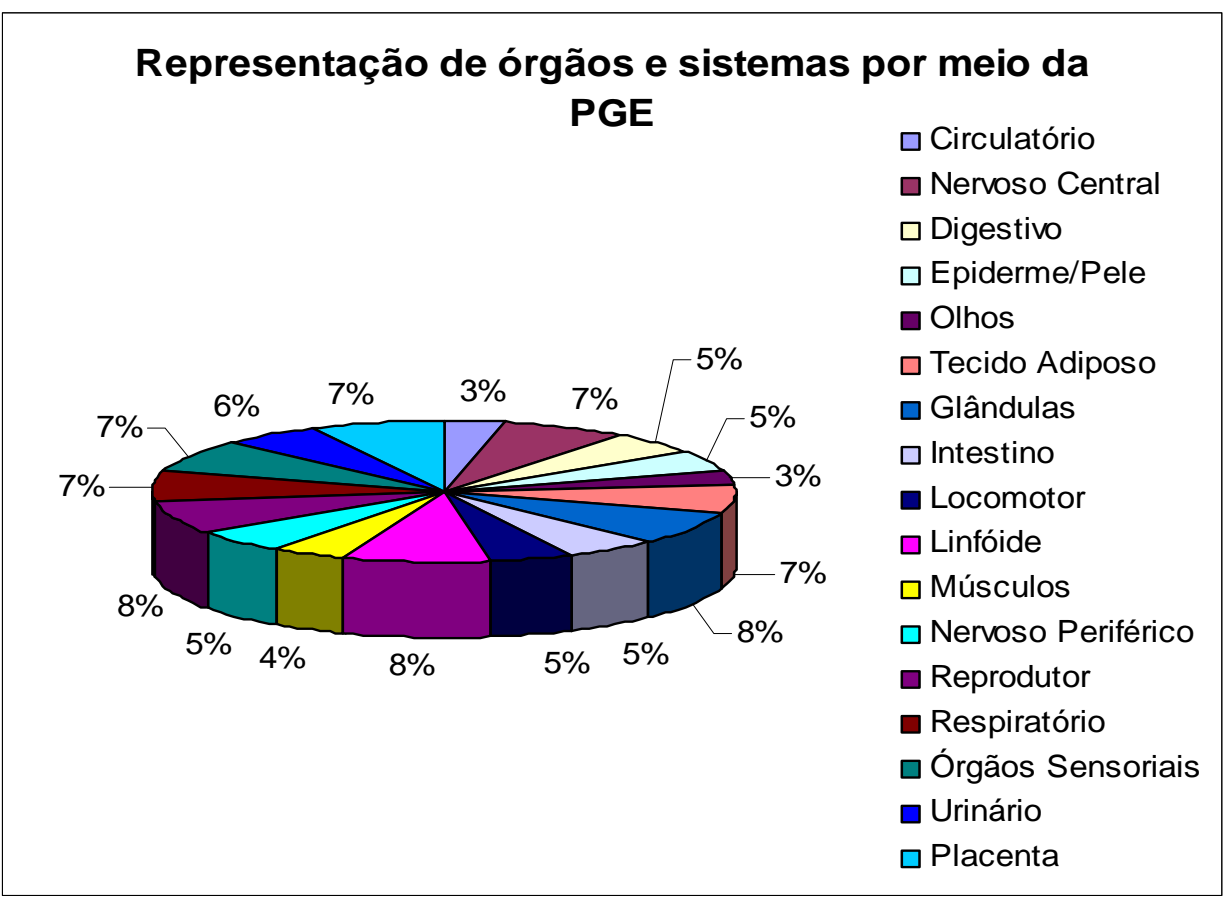

Figura 27. Representação da expressão gênica específica de tecidos e órgãos em células mTEC. Os genes significativamente induzidos em células mTEC transfectadas com RNAi anti-Aire, dos 4500 analisados, foram anotados caracterizando a expressão promíscua, representando os antígenos relacionados a tecido.

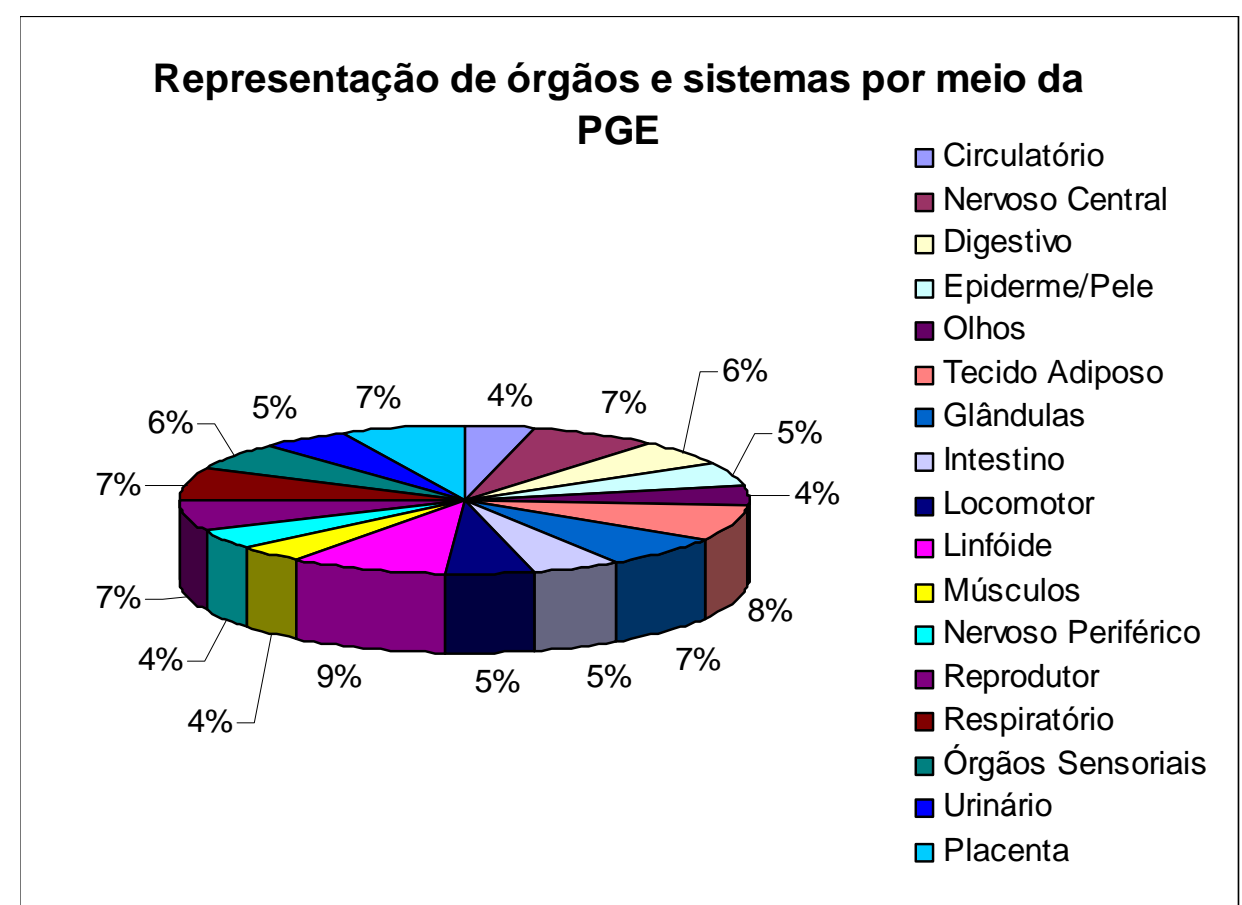

Figura 28. Representação da expressão gênica específica de tecidos e órgãos em células mTEC. Os genes significativamente reprimidos em células mTEC transfectadas com RNAi anti-Aire, dos 4500 analisados, foram anotados caracterizando a expressão promíscua, representando os antígenos relacionados a tecido. 
6.8. Influência do silenciamento do transcrito do gene Aire sobre as redes de interações gênicas das células mTEC

A figura 29 mostra a rede de interações gênicas das células mTEC controle e a figura 30 o mesmo tipo de rede sob a influência do silenciamento parcial do transcrito do gene Aire. É possível observar que as células mTEC controle mostraram o transcrito Gucy2d (guanylate cyclase $2 d$ ) que pode ser interpretado como um "nó gênico", pois a grande maioria dos genes analisados exercem influência sobre este transcrito, tanto de indução como de repressão.

A rede de células mTEC tratadas com RNAi anti-Aire, ainda continuou exibir o transcrito Gucy2d como nó gênico. Entretanto, os tipos de interações se alteraram de maneira importante. Nota-se que a maioria das interações que partem do transcrito Gucy2d é de repressão sobre outros transcritos.

Os transcritos dos genes presentes nas redes bem como os tipos de interações entre eles, encontram-se listados nas tabelas IV e V do anexo III. 


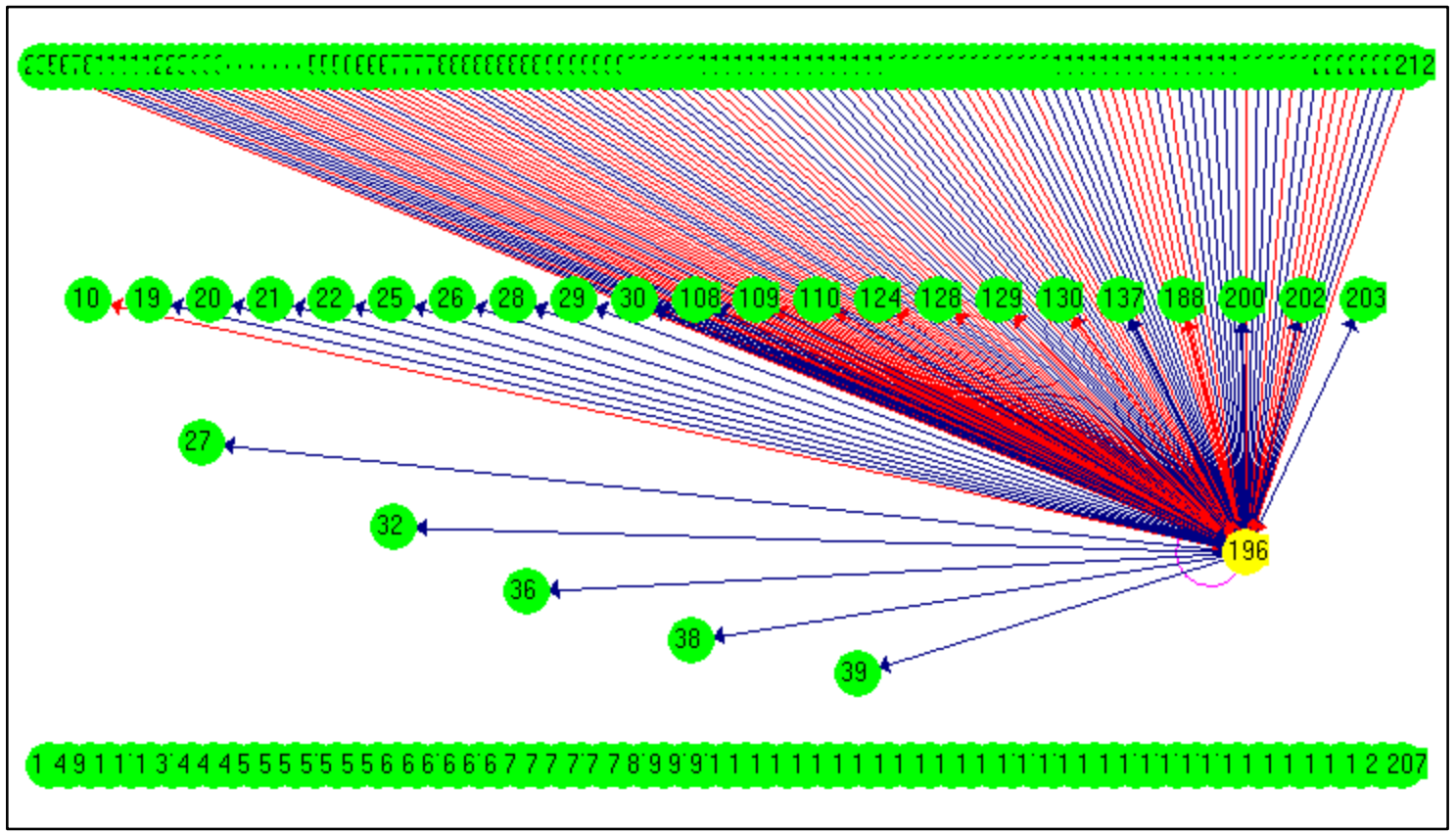

Figura 29. Rede de interações gênicas de células medulares epiteliais tímicas (mTEC linhagem 3.10) cultivadas sob condições controle.

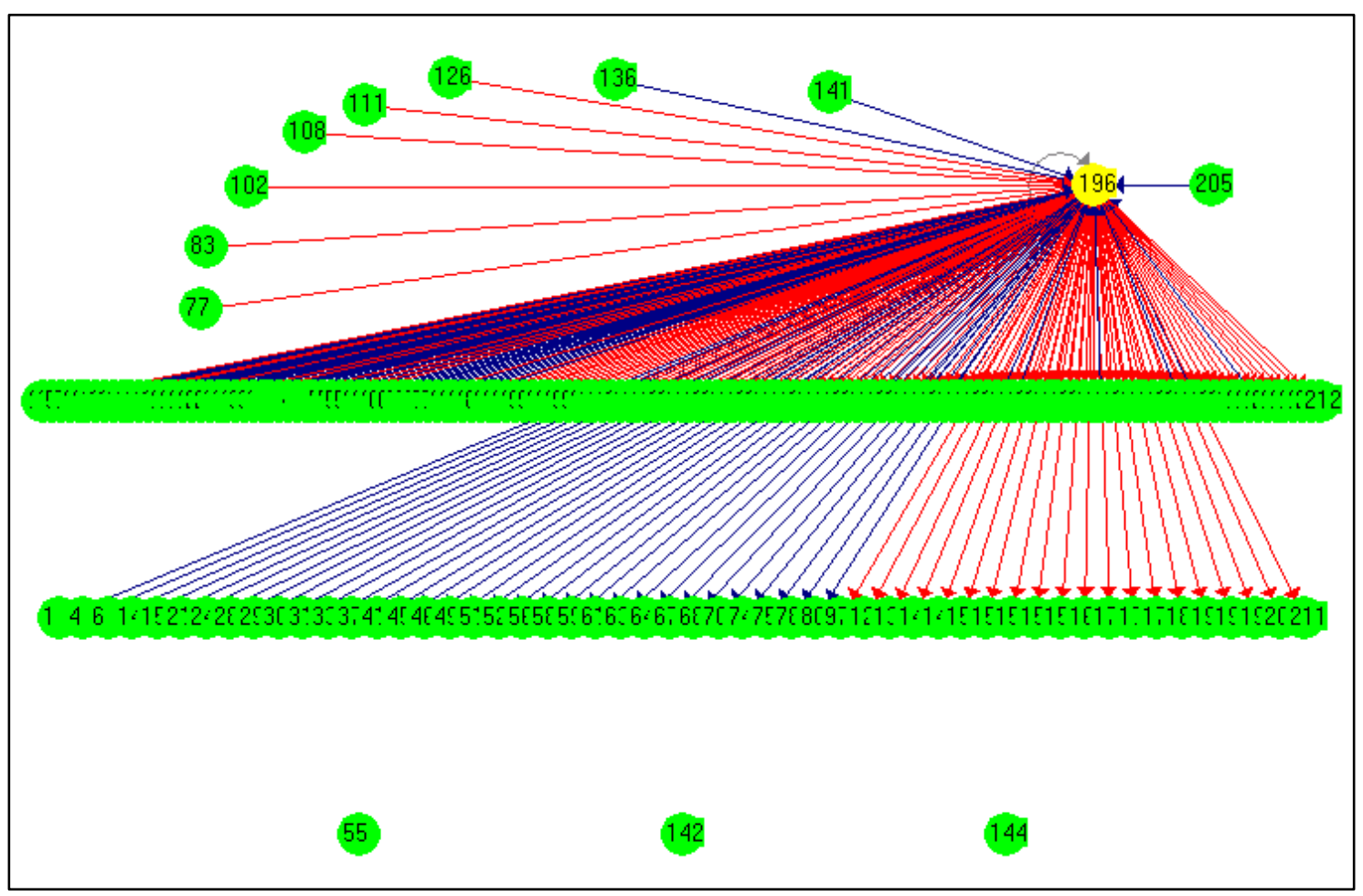

Figura 30. Rede de interações gênicas de células medulares epiteliais tímicas (mTEC linhagem 3.10) transfectadas com RNAi anti-Aire. 
Discussão 


\section{DISCUSSÃO}

Este trabalho foi realizado tendo como base nosso interesse na investigação das bases genético-moleculares do controle imunológico do próprio-não-próprio ou da indução de tolerância, pois esta é uma das propriedades essenciais do sistema imune a qual contribui com a homeostase do corpo e impedindo manifestações auto-imunes.

Como discutem Kyewski e Derbinski, (2004) e Magalhães et al (2006), a idéia germinal da teoria da seleção clonal e da discriminação do próprio foi desenvolvida por Paul Ehrlich há mais de 100 anos (Ehrlich e Morgenroth, 1901) e representa até hoje a orientação conceitual básica de toda a investigação imunológica.

Neste contexto, a demonstração da deleção clonal de linfócitos auto-reativos é considerada como uma das mais importantes descobertas, a qual tem contribuído com nossa compreensão contemporânea do sistema imune adaptativo (Schwartz e Mueller, 2003) e inato (Medzhitov e Janeway, 1997).

As duas vias conhecidas da resposta imune são caracterizadas pelo uso limitado de receptores antimicrobianos germline no sistema imune inato ou por receptores de células T (TCR) ou imunoglobulinas (Ig) gerados somaticamente e altamente diversos no sistema imune adaptativo.

A molécula heterodimérica de TCR $(\mathrm{TCR} \alpha / \beta)$ pode representar o conceito funcional do sistema imune devido a sua propriedade de reconhecer instantaneamente a molécula própria do complexo principal de histocompatibilidade (MHC) e o peptídeo antigênico não-próprio. 
A tolerância do repertório das células $\mathrm{T}$ ao próprio é adquirida durante o desenvolvimento durante o desenvolvimento das células $\mathrm{T}$ imaturas, um fenômeno dependente da avidez da interação entre um TCR específico, o MHC e o peptídeo próprio. O local no corpo onde ocorrem tais interações é o timo. O repertório de células $\mathrm{T}$ nascente no timo determina a diversidade de antígenos próprios e a especificidade da tolerância central.

Nós concordamos com Kyewski e Derbinski (2004) assumindo que tolerância central inclui os mecanismos intra-tímicos pelos quais as células T passam pelo reconhecimento dos antígenos próprios. De acordo com esse conceito, as células $T$ reguladoras ( $T_{\text {reg}}$ ) auto reativas são selecionadas no timo, mesmo se desempenharão seu papel na periferia.

De fato, todos os sub conjuntos de células apresentadoras de antígenos (APCs) tais como as células tímicas epiteliais corticais (cTECs), as epiteliais medulares (mTECs), células dendríticas tímicas e os macrófagos desempenhas seus papéis na apresentação de antígenos próprios no timo (Klein e Kyewski, 2000).

Entretanto, a expressão de antígenos restritos a tecidos (TRAs) no timo, a qual representa uma característica chave na efetivação da representação do próprio, foi reconhecida recentemente na história da imunologia.

A evidência da expressão intratímica de TRAs em camundongos e no homem, a qual foi referida de expressão gênica promíscua (PGE) (Jolicoeur et al., 1994; Derbinski et al., 2001; Gotter et al., 2004), reforçou o conceito de tolerância central a antígenos dos tecidos próprios.

Antes desta evidência, a tolerância periférica, isto é, mecanismos pelos quais a seleção das células T em direção aos TRAs ocorreriam fora 
do timo, dominava o cenário na explicação da discriminação do próprionão-próprio (Alferink et al., 1999; Walker \& Abbas, 2002).

A PGE no timo está causando uma reversão no escopo do entendimento da tolerância central, levando a uma concepção não ortodoxa dos possíveis mecanismos da discriminação do próprio-nãopróprio (Kyewski et al., 2002; Gallegos e Bevan, 2006).

A principal implicação desta expressão gênica heterogênea no timo está associada com a manutenção da homeostase imunológica no corpo, controlando as reações auto-imunes patogênicas.

As primeiras evidências desse fenômeno foram obtidas usando a técnica de real-time PCR (RT-PCR) focando antígenos de reações autoimunes, como a insulina, o receptor de acetilcolina ou a proteína básica da mielina. Atualmente, a PGE é reconhecida como ao invés de seletiva, o conjunto de genes expressos é tão variado quanto possível, chegando a abranger de 5 a 10\% do genoma funcional humano ou do camundongo (Derbinski et al., 2001; Gotter et al., 2004; Kyewski e Derbinski, 2004).

Atualmente, para explorar a expressão gênica em grande escala no timo, a estratégia de escolha é a tecnologia dos microarrays. O grupo de $\mathrm{B}$. Kyewski e J. Derbinski do Centro Alemão de Pesquisas sobre o Câncer em Heidelberg, Alemanha utiliza os oligo arrays da Affymetrix, os quais permitiram uma extensa caracterização da PGE no timo murino (Kyewski \& Derbinski, 2004).

De fato a técnica de microarrays seja em nylon ou lâminas de vidro, tem sido realizada por mais de 10 anos nas mensurações da expressão gênica em grande escala no timo (Nguyen et al, 1995; Espanhol et al., 2004; Puthier et al., 2004; Magalhães et al., 2005, Cardoso et al., 2006, Sousa Cardoso et al., 2006). 
Com relação à técnica de cDNA microarrays desenvolvida no próprio laboratório para propósitos de análise de PGE no timo murino é de especial interesse a biblioteca de cDNA denominada "Soares thymus 2NbMT cDNA library" disponível no IMAGE Consortium (http://image.llnl.gov). Essa é uma biblioteca de ESTs (expressed sequence tags) normalizada, preparada do timo total de um camundongo macho adulto jovem de quatro semanas da linhagem C57Bl/6J (mesmo background genético da linhagem de células mTEC 3.10 utilizada neste trabalho).

Essa biblioteca é composta de mais de 25.000 clones de cDNA (resequenciados) representando a maioria, se não todos, os genes expressos do camundongo. Portanto, ela representa um recurso precioso para a preparação de cDNA microarrays "especializados em timo" muito úteis na pesquisa de PGE.

Por isso é que utilizamos essa biblioteca no presente estudo, além de dominarmos todas as etapas da tecnologia dos microarrays em nosso próprio laboratório.

Portanto, o sistema modelo estava organizado: de um lado as células mTEC em cultura e de outro o cDNA microarray tímico.

Nossa primeira questão foi avaliar se as células mTEC expressam em cultura os genes de TRAs, conferindo a expressão gênica promíscua.

Como a análise de dados de microarrays envolve o teste estatístico SAM (Tusher et al., 2001), o qual recupera somente os valores de expressão com alta significância, das 4.500 seqüências de cDNA presentes no microarray foram possíveis recuperar 1.611 por meio da função multiclass do programa SAM (figura 23) ou 211 seqüências usando a comparação pareada (figura 25). 
Tais seqüências foram então comparadas com as do banco de dados GNF SymAtlas (http:// symatlas.gnf.org/SymAtlas) (Su et al.,2004) e, com a anotação minuciosa de cada um dos tecidos e/ou órgãos que são representados pelas seqüências, colocamo-las num contexto de PGE exibido pelas células mTEC normais.

O resultado mostrado na figura 28 mostra que foi possível associar a expressão gênica no timo com representação antigênica de tecidos e/ou órgãos.

Portanto, conseguimos validar a primeira hipótese do presente trabalho com a resposta de que as células mTEC em cultura reproduzem PGE.

Quanto à representação de tecidos e/ou órgãos observamos que há uma distribuição relativamente uniforme dos 17 sistemas, variando de quatro a nove por cento. Embora o silenciamento parcial de Aire tenha desencadeado a indução de vários genes e repressão de outros nas células mTEC (figura 25), modulando assim os níveis de expressão dos genes TRAs (PGE), ela não alterou a representatividade dos sistemas, a qual permaneceu praticamente inalterada (figuras 27 e 28).

Um fato que nos chamou a atenção foi o de que a PGE também é caracterizada pela expressão diferencial dos genes, ou seja, foi possível identificar um grupo de genes reprimidos e outro de induzidos, com as respectivas variações individuais nos níveis de expressão em cada grupo.

Nesse contexto, entra nossa segunda questão que foi referente ao controle da PGE nas células mTEC sendo o principal enfoque desta Tese.

$\mathrm{Na}$ realidade esse aspecto é foco de muito interesse na imunogenética atual. A descoberta mais relevante até o momento foi a do 
gene AIRE (do inglês autoimmune regulator) no homem, o qual é considerado como principal controlador positivo da PGE em mTECs.

Esse gene foi identificado inicialmente como lócus de susceptibilidade da doença autoimune APECED (autoimmune polyendocrinopathy-candidiasis ectodermal dystrophy) também conhecida como APS1, a qual foi reconhecida como síndrome há mais de 60 anos atrás (Leonard, 1946).

Entretanto, o maior salto no entendimento da APECED começou em 1997 quando dois grupos de pesquisadores utilizaram estratégias de clonagem posicional para identificar o gene em questão (Finnish-German APECED Consortium, 1997; Nagamine et al., 1997).

Como discute Mathis e Benoist (2007), a proteína codificada por este lócus foi denominada $A I R E$, a qual é uma grande proteína contendo 545 resíduos de aminoácidos com vários domínios remanescentes daqueles achados em reguladores transcricionais, notavelmente módulos do tipo zinc fingers, os quais servem como elementos de ligação com DNA em alguns fatores de transcrição. Mas notou-se que em AIRE faltam resíduos críticos de interação com DNA (Gibson et al., 1998).

Mais de 60 mutações foram localizadas no gene AIRE de diferentes pacientes com APECED, sendo que esse aspecto é também foco de intensas pesquisas, inclusive na tentativa de relacionar tais mutações com outras doenças autoimunes.

À época de sua descoberta, havia uma controvérsia significativa entre os autores acima citados a respeito do padrão da expressão de AIRE, reivindicando uma distribuição abrangente envolvendo diferentes órgãos (Finnish-German APECED Consortium, 1997), ou uma distribuição restrita aos órgãos linfóides, especialmente o timo 
(Nagamine et al., 1997; Heino et al., 1999). Esta discrepância sem dúvida refletiu diferenças da especificidade das sondas moleculares e na confiabilidade da técnica sendo finalmente resolvida em favor da última teoria.

O conhecimento da estrutura e da expressão de AIRE levou a várias hipóteses de como ele pode operar para controlar a auto-imunidade. Estas hipóteses incluem: determinando a organização do estroma tímico; controlando a tolerância dos timócitos; regulando respostas das células B e das células T aos estímulos antigênicos; induzindo apoptose de células parenquimais e desse modo realçando a apresentação de seus antígenos; ou impinging na diferenciação de células T regulatórias $\mathrm{CD} 4{ }^{+} \mathrm{CD} 25^{+}(\mathrm{TReg})$ (Peterson et al., 1998).

Os estudos em camundongos permitiram uma dissecção extensiva de como Aire opera. Primeiramente, a disponibilidade de tecidos e de reagentes apropriados para a classificação celular permitiu um delineamento de onde Aire é expresso. Encontra-se em órgãos linfóides, especialmente o timo, dentro do qual é expresso na maior parte por células epiteliais medulares (MECs) mas também, embora em uns níveis muito mais baixos, por células dendríticas (DCs) (Mathis \& Benoist, 2007).

Encontrar Aire em MECs (hoje sabemos que são as células mTEC que expressam Aire) era intrigante por causa das sugestões que este tipo células está envolvido na seleção negativa de timócitos auto-reativos (Kishimoto \& Sprent, 1997) e por causa da emergência coincidente dos dados que estabelecem que os transcritos que codificam antígenos tecido específicos (TRAs) são expressos ectopicamente especificamente por mTECs (Kyewski \& Klein, 2006). Assim, levantou-se a hipótese que Aire regula a transcrição tímica dos genes que codificam TRAs, e controla 
desse modo a tolerância e conseqüentemente a auto-imunidade (Mathis \& Benoist, 2007).

Esta hipótese pode ser avaliada diretamente em camundongos Aire-knockout (Anderson et al., 2002; Ramsey et al., 2002; Kuroda et al., 2005). Estes animais foram criados para ter um sistema imune relativamente normal, mas eram afetados com auto-imunidade de múltiplos órgãos, como indicado por infiltrados inflamatórios e por autoanticorpos no soro.

A purificação de mTECs de camundongos tipo selvagem e AIREknockout, seguida do perfil da expressão gênica, revelou que certamente Aire promove a transcrição de um grande número genes que codificam antígenos relacionado a tecido (TRA) (Anderson et al., 2002 e Anderson et al., 2005) e associados com a seleção negativa de células T auto-reativas (Nagafuchi et al., 2006). Aire também regula positiva ou negativamente a transcrição em mTECs de um conjunto de genes que não codificam TRAs (Mathis \& Benoist, 2007).

Interessante é que a transcrição de um número de genes de TRAs, tais como aqueles codificadores da proteína C-reativa e da ácido glutâmico decarboxilase de 67kDa (GAD67), pareceu ser independente da expressão de Aire, e esta observação foi confirmada recentemente em um estudo mais amplo (Derbinski et al., 2005).

Aire também regula positivamente ou negativamente a transcrição, em mTECs, de genes que não codificam TRAs. O significado do controle por Aire da expressão de TRAs no timo em relação às manifestações autoimunes observados em camundongos Aire-knockout foi substanciado associando a perda deste controle com o desenvolvimento de autoanticorpos contra olho e estomago e, no primeiro caso, demonstrando 
também que a falta da expressão de TRAs no timo era suficiente produzir a auto-imunidade (Mathis \& Benoist, 2007).

Analisando camundongos duplo-transgênicos Aire-knockout e mutação num dos genes de receptor de célula T (TCR)-antígeno próprio, no qual células $\mathrm{T}$ antígeno-próprio-específicas podem ser seguidas, mostrou-se que, na ausência de Aire, os timócitos auto-reativos podem escapar da deleção clonal usual que os impede de migrar à periferia. (Anderson et al., 2005b; Liston et al., 2003; Liston et al., 2004).

Embora estes estudos ligassem claramente o controle da expressão de TRA por Aire com a deleção clonal, diversos trabalhos indicaram que a falta de Aire compromete a indução da tolerância sem afetar a transcrição dos genes de TRAs no timo (Anderson et al., 2005; Kuroda et al., 2005; Niki et al., 2006). A questão ainda permanece em aberto, havendo ainda interesse considerável na definição do papel de Aire na indução da tolerância central além de seu controle da expressão de TRAs.

Trabalhos recentes reportam que Aire liga-se diretamente à proteína ligante de CREB (CBP - CREB-binding protein) (Pitkanen et al., 2000). A proteína CBP funciona como um coativador transcricional para uma variedade de fatores de transcrição incluindo Jun, Fos, receptores nucleares, NFkB, e as proteínas STAT (Pitkanen et al., 2000). CBP apresenta três domínios ricos em histidina-cisteína ( $\mathrm{CH} 1, \mathrm{CH} 2$ e $\mathrm{CH} 3)$, envolvidos em interações específicas proteína-proteína (Janknecht \& Hunter, 1996; Bhattacharya; 1996). Esses achados sugerem que CBP participa como integrador de vias de sinalização múltiplas (Pitkanen et al., 2003).

A proteína AIRE se liga a CBP nos domínios de interação $\mathrm{CH} 1 \mathrm{e}$ CH3 (Pitkanen et al., 2000). No núcleo, Aire forma discretos corpos nucleares que parecem, mas são distintos dos corpos nucleares (NBs) da 
PML (leucemia promielocitica). A significância funcional atual da interação entre AIRE e CBP e o papel dos NBs-AIRE na transcrição ainda não foi bem estudada. É possível que CBP forme a ligação entre AIRE, possíveis outras proteínas que interagem com AIRE e a maquinaria transcricional basal (Pitkanen et al., 2005).

AIRE e CBP sinergisticamente ativam a transcrição de dois repórteres diferentes: o elemento que contem o promotor de GAL4ligante e o promotor mínimo de IFNb. Além disso, AIRE e CBP induzem colaborativamente a expressão endógena do mRNA de IFNb.

As análises da localização subnuclear sugerem que os corpos de AIRE não são locais da transcrição. Em adição, ao ocorrer no mesmo NBs, AIRE, e CBP têm a posição espacial diferente dentro dos corpos (Pitkanen et al., 2005).

Pitkanen et al. (2005) em seu trabalho suportam fortemente a idéia que AIRE pode provocar diretamente a expressão dos antígenos-próprios como um regulador transcricional em colaboração com CBP.

Estudos adicionais são necessários para identificar como AIRE seleciona seus genes do alvo e para caracterizar quais são os mecanismos moleculares da ação colaborativa de AIRE e de CBP na transcrição.

As proteínas PIAS também foram identificadas como novos parceiros na interação com AIRE (Ilmarinen et al., 2007). A expressão de AIRE realça a formação de PIAS1 NBs. PIAS1 pode atrair AIRE em complexos contendo SUMO1 e o processo é dependente de SIM e de PIAS1. PIAS1 e AIRE ativam simultaneamente o promotor humano da insulina, um gene conhecido como alvo de AIRE, e SP-RING é requerida para esta ativação. Além disso, AIRE reprime e PIAS1 ativa o promotor de CSTB, usado como um modelo para um promotor housekeeping, e 
ambos SP-RING e SIM são necessários para sua ativação por PIAS1. Desta forma, acredita-se que AIRE e PIAS1 interagem funcionalmente para regular as atividades dos genes do alvo de AIRE (Ilmarinen et al., 2007).

Aire interage com e é fosforilado pelo complexo DNA-PK de proteínas DNA-PKcs, Ku70 e Ku80. Ensaios de fosforilação in vitro demonstraram que DNA-PK fosforila a proteína AIRE nos resíduos Thr68 e Ser156, e mutações nesses sítios de fosforilação diminuem significantemente a atividade transcricional de AIRE (Liiv et al., 2007).

Modificações pós-transctricionais, como fosforilação, acetilação e ubiquitinação, são comumente usados para regular a atividade de fatores e reguladores de transcrição. Livv et al. (2007) descrevem a fosforilação de sítios de AIRE e propõem que este estado de fosforilação é importante para sua atividade transativadora. Entretanto, várias questões permanecem, inclusive quais são os sinais que levam a fosforilação de AIRE e como essa fosforilação está conectada à sua função no timo.

Outros fatores adicionais devem estar envolvidos na regulação da PGE. Giraud et al. (2007) descrevem um mecanismo que controla a transcrição tímica de um gene de auto-antígeno humano restrito a tecido, o CHRNA1. Este gene codifica a subunidade $\alpha$ do receptor de acetilcolina muscular, o qual é o principal alvo dos auto-anticorpos patogênicos na myasthenia gravis auto-imune. Foi observado que uma variante deste gene previne a ligação do IRF8 (interferon regulatory factor 8) e revogando a atividade do promotor CHRNA1 em células epiteliais tímicas in vitro, revelando uma função crítica de AIRE e a via de sinalização do interferon na regulação da expressão quantitativa deste auto-antigeno no timo, sugerindo que eles estejam juntos no ponto de partida para a tolerância versus a auto-imunidade. 
Boehm et al. (2003) afirmaram que o sinal via linfotoxina (LT) regula a composição e organização do timo, particularmente do compartimento medular epitelial. Enquanto isso uma série de trabalhos tem indicado sinais de que a LT controla a expressão de AIRE, mediando a transcrição ectópica dos genes que codificam uma variedade de antígenos relacionados a tecidos e promovendo a deleção clonal de timócitos auto-reativos e não a composição/estrutura do epitélio tímico (Chin et al., 2003; Chin et al., 2006; Zhu M et al., 2006). Para tentar elucidar essa questão, Venanzi et al (2007) examinou o papel da via da LT no timo e sua relação com AIRE e a transcrição gênica de TRAs, usando uma combinação de ferramentas de histologia, citometria de fluxo e perfis de expressão gênica. Concluíram que a via LT permanece sendo importante no domínio do desenvolvimento/organização do timo e parece não participar como um protagonista crítico na tolerância mediada por AIRE.

As observações acima relatadas mostram claramente que AIRE (Aire) é um controlador central, mas não atua sozinho, necessitando outros genes (ou suas respectivas proteínas) no mecanismo da modulação da expressão de genes de TRAs.

Neste ponto é que procuramos inserir o presente trabalho, formulando a hipótese de que Aire é um controlador upstream de uma rede gênica de TRAs.

Para começar a testar tal hipótese, utilizamos o método de silenciamento gênico (RNA interferente ou RNAi) dirigido contra o transcrito do gene Aire.

A utilização de RNAi na pesquisa tem sido amplamente difundida, pois a possibilidade de "silenciar" a expressão de genes pode levar a aplicações na pesquisa básica como no seu uso clínico (Chen et al, 2003; 
Strillacci et al, 2006).

Nossos resultados mostram que o silenciamento do transcrito de Aire foi parcial (figura 19), mas mesmo assim, foi possível identificar perfis de expressão gênica distintos comparando células mTEC controle e as transfectadas com RNAi anti-Aire (figura 23). O silenciamento parcial passou inclusive a ser de interesse, pois nos permitiu evidenciar os genes de TRAs com forte dependência de Aire.

Para a análise da PGE escolhemos trabalhar somente com um dos grupos controle (mTEC) versus células mTEC transfectadas com RNAi anti-Aire e, conseqüentemente, analisando aquele grupo de genes altamente dependentes de Aire.

Como é possível observar na figura 25, houve uma separação das amostras de acordo com o grupo de células e uma modulação dos níveis de expressão dos genes TRAs após a transfecção com RNA interferente. Dos 212 genes diferencialmente expressos, 80 encontravam-se induzidos (dos quais 37 ainda representam ESTs ou expressed sequence tags) e 132 reprimidos (17 ESTs) em células mTEC transfectadas, indicando uma diminuição do número de genes de TRAs expressos após o silenciamento de Aire (figuras 27 e 28).

Os sistemas circulatório, digestivo, olhos, tecido adiposo e sistema linfóide tiveram sua representatividade diminuída após a transfecção com RNAi anti-Aire. Já os sistemas glandular, nervoso periférico, reprodutor, órgãos sensoriais e sistema urinário apresentaram uma representatividade aumentada enquanto que nos sistemas nervoso central, locomotor, muscular, respiratório, epiderme/pele, intestino e placenta ela permaneceu inalterada.

Para analisar as interações em rede entre os genes diferencialmente expressos após a transfecção com o RNAi anti-Aire, escolhemos o 
programa Genenetwork (Wu et al., 2004) devido as suas características peculiares que melhor se enquadram aos nossos tipos de dados.

Dentre os quatro modelos de inferência diferentes que o programa GeneNetwork oferece para extrair a "matriz de regulação gênica" dos dados de expressão gênica, o modelo linear foi escolhido para análise dos dados. Este é um método contínuo que usa equações diferenciais ordinárias lineares para descrever o sistema. Embora seja a metodologia mais simplista que o programa apresenta, permite observar as principais e mais importantes informações que envolvem os genes em questão. Para a obtenção da rede gênica representando as interações entre os genes, é assumido que o nível de expressão de um componente num determinado tempo é dado pela somatória dos pesos de todos os outros genes. Assim, o nível de expressão neste tempo é influenciado pelo nível de expressão dos tempos anteriores.

Nessas redes é possível estabelecer cinco tipos de interação entre os genes: interação de ativação, inibição, auto-regulação negativa e positiva e dupla interação (dois sentidos) permitindo esclarecer como é a regulação das interações na situação em estudo.

A rede de interações gênicas das células mTEC controle apresentada na figura 29 mostra o transcrito Gucy2d (guanylate cyclase $2 d$ ) como único nó gênico, ou seja, um gene que participa de um número maior de interações. O mesmo tipo de rede, porém sob a influência do silenciamento parcial do transcrito do gene Aire está apresentada na figura 30. Nesta última, o transcrito do gene Gucy2d também se apresenta como único nó gênico.

Comparando-se as duas redes, observamos que, embora apresentem o mesmo único nó gênico, as relações entre Gucy2d e os demais genes se alteraram de maneira significativa. 
Na rede de células controle observamos que há uma regulação de diversos genes sobre Gucy2d, sendo que este, por sua vez, exerce influência sobre um número relativamente pequeno de genes (tabela IV, anexo III). Já na rede das células sob influência do silenciamento parcial do transcrito do gene Aire notou-se que a maioria das interações partem de Gucy2d e são, em sua maioria, de inibição sobre outros transcritos (tabela $\mathrm{V}$, anexo III).

Estes resultados mostram que sob diminuição do transcrito de Aire, o gene Gucy2d passa a ser um controlador negativo sobre genes de TRAs.

Embora o gene Aire não esteja representado no microarray usado nesse estudo e, consequentemente não apareça nas redes, ficou clara sua influência sobre as interações com os demais transcritos na célula mTEC.

As observações das redes são probabilísticas e precisamos partir para métodos de validação, tais como a utilização do algoritmo de Markov (Ellrott et al., 2002), com o qual podemos avaliar seqüências de DNA quanto ao seu potencial de interagir com fatores de transcrição como Aire. 
Conclusões 


\section{CONCLUSÕES}

+ Células tímicas epiteliais medulares (mTECs) expressam, em cultura, genes codificadores de antígenos relacionados a tecidos (expressão gênica promíscua);

+ Genes que caracterizam a PGE estão conectados em rede nas células mTEC;

+ Um nó gênico pode agir como intermediário no seu controle e

+ $\mathrm{O}$ gene AIRE (autoimmune regulator) em redes PGE controla a expressão gênica promíscua nas células mTEC, numa posição upstream. 
Referências Bibliográficas 


\section{REFERÊNCIAS BIBLIOGRÁFICAS}

Abbas AK \& Lichtman AH (2005). Imunologia Celular e Molecular. 5a Edição. W. B. Saunders Company. Philadelphia Penn. USA. Ed. Elsevier, 576p.

Alferink J, Aigner S, Reibke R, Hämmerling GJ, Arnold B (1999). Peripheral T cell tolerance: the contribution of permissive $\mathrm{T}$ cell migration into parenchymal tissues of the neonate. Immunol. Rev. 169, 255-261.

Alonso L, Fuchs E (2003). Stem cells of the skin epithelium. Proc. Natl. Acad. Sci. USA 100: 11830-5.

Anderson G, Jenkinson EJ (2001). Lymphostromal interactions in thymic development and function. Nat Rev Immunol. 1(1):31-40.

Anderson G, Lane PJL, Jenkinson EJ (2007). Generating intrathymic microenvironments to establish T-cell tolerance. Nat. Rev. Immunol. 7(12): 954-63.

Anderson MS, Venanzi ES, Klein L, Chen Z, Berzins SP, Turley SJ, von Boehmer H, Bronson R, Dierich A, Benoist C, Mathis D (2002). Projection of an immunological self-shadow within the thymus by aire protein. Science 298: 1395.

Anderson MS, Venanzi ES, Chen Z, Berzins SP, Benoist C, Mathis D (2005). The NOD mouse: a model of immune dysregulation. Annu. Rev. Immunol. 23: 447.

Anderson MS, Venanzi ES, Chen Z, Berzins SP, Benoist C, Mathis D (2005b). The cellular mechanism of Aire control of T cell tolerance. Immunity 23, 227-239.

Bansal M, Belcastro V, Ambesi-Impiombato A, di Bernardo D (2006). How to infer gene networks from expression profiles. Molecular Systems Biology 3: 1-10. 
Barthlott T, Keller MP, Krenger W, Holländer GA (2006). A short primer on early molecular and cellular events in thymus organogenesis and replacement. Swiss Med Wkly. 136(23-24): 365-369.

Basso K, Margolin AA, Stolovitzky G, Klein U, Dalla-Favera R, Califano A (2005). Reverse engineering of regulatory networks in human B cells. Nature Genetics 37(4):382-90.

Benjamini Y, Hochberg Y (1995) Controlling the false discovery rate - a practical and powerful approach to multiple testing. J. R. Stat. Soc. B. 57: 289-300.

Bhattacharya S, Eckner R, Grossman S, Oldread E, Arany Z, D'Andrea A, Livingston DM. (1996). Cooperationof Stat2 and p300/CBP in signaling induced by interferon alpha. Nature 383:344-347.

Blackburn CC, Manley NR (2004). Developing a new paradigm for thymus organogenesis. Nat Rev Immunol 4 (4): 278-289.

Bleul CC, Corbeaux T, Reuter A, Fisch P, Mönting JS, Boehm T (2006) Formation of a functional thymus initiated by a postnatal epithelial progenitor cell. Nature 441(7096):992-6.

Bodey B, Bodey B Jr, Siegel SE, Kaiser HE (1997). Involution of the mammalian thymus, one of the leading regulators of aging. In Vivo. 11(5):421-40.

Booth C, Potten CS (2000). Gut instincts: thoughts on intestinal epithelial stem cells. J. Clin. Invest. 105 : 1493-9.

Boehm T, Scheu S, Pfeffer K, Bleul CC (2003). Thymic medullary epithelial cell differentiation, thymocyte emigration, and the control of autoimmunity require lympho-epithelial cross talk via LTbetaR. J. Exp. Med. 198: 757-69.

Boehm T \& Bleul CC (2006). Thymus-homing precursors and the thymic microenvironment. Trends Immunology 27, 477-484.

Cardoso RS, Junta CM, Macedo C, Magalhães DA, Silveira EL, Paula MO, Marques MM, Mello SS, Zárate-Bladés CR, Nguyen C, Houlgatte R, Donadi EA, Sakamoto-Hojo ET, Passos GA. 2006 Hybridization signatures 
of gamma-irradiated murine fetal thymus organ culture (FTOC) reveal modulation of genes associated with T-cell receptor $\mathrm{V}(\mathrm{D}) \mathrm{J}$ recombination and DNA repair. Molecular Immunology 43(5):464-472.

Cheng MH, Shum AK, Anderson MS (2007). What's new in the Aire? Trends Immunology 28(7), 321-327.

Chin RK, Lo JC, Kim O, Blink SE, Christiansen PA, Peterson P, Wang Y, Ware C, Fu YX (2003). Lymphotoxin pathway directs thymic Aire expression. Nature Immunology 4: 1121-1127.

Chin RK, Zhu M, Christiansen PA, Liu W, Ware C, Peltonen L, Zhang X, Guo L, Han S, Zheng B, Fu YX (2006). Lymphotoxin pathway-directed, autoimmune regulator-independent central tolerance to arthritogenic collagen. J Immunol. 177(1):290-7.

Cordier AC, Haumont SM (1980). Development of thymus, parathyroids, and ultimo-branchial bodies in NMRI and nude mice. Am J Anat. 157(3):22763.

Derbinski J, Schulte A, Kyewski B, Klein L (2001). Promiscuous gene expression in medullary thymic epithelial cells mirrors the peripheral self. Nature Immunology 2: 1032-1039.

Derbinski J, Gäbler J, Brors B, Tierling S, Jonnakuty S, Hergenhahn M, Peltonen L, Walter J, Kyewski B (2005). Promiscuous gene expression in thymic epithelial cells is regulated at multiple levels. J. Exp. Med. 202(1): 33-45.

Di Bernardo D, Thompson MJ, Gardner TS, Chobot SE, Eastwood EL, Wojtovich AP, Elliott SJ, Schaus SE, Collins JJ (2005). Chemogenomic profiling on a genome-wide scale using reverse-engineered gene networks. Nature Biotechnology 23, $377-383$.

Donate PB (2008). Análise da Expressão Gênica Promíscua no Timo de Camundongos DBA-1 e DBA-2 Durante a Imunização com Colágeno: Modelo de Susceptibilidade/Resistência a Artrite Reumatóide. 
Dissertação de Mestrado, Faculdade de Medicina de Ribeirão Preto, USP (Orientador: Geraldo A. S. Passos).

Dooley J, Erickson M, Gillard GO, Farr AG (2006). Cervical thymus in the mouse. J. Immunol. 176(11):6484-90.

Ehrlich P, Morgenroth J II (1901). Ueber Hämolysine. Berl. Klin. Wochenschr. $28,251-257$.

Eisen, M. B., Spellman, P. T., Brown, P. O., and Botstein, D. (1998). Cluster analysis and display of genome-wide expression patterns. Proc. Natl. Acad. Sci. USA 95, 14863-14868.

Espanhol AR, Macedo C, Junta, CM, Cardoso, RS, Victorero, G, Loriod, B, Nguyen, C, Jordan, B, Passos JR., GAS (2003). Gene expression profiling during thymus ontogeny and its association with TCRVB8.1-DB2.1 rearrangements of inbred mouse strains. Molecular and Cellular Biochemistry 252:223 - 228 .

Ellrott K, Yang C, Sladek FM, Jiang T (2002). Identifying transcription factor binding sites through Markov chain optimization. Bioinformatics 18 (Suppl. 2): S100-S109.

Finnish-German APECED Consortium (1997). An autoimmune disease, APECED, caused by mutations in a novel gene featuring two PHD-type zinc-finger domains. Nature Genetics 17, 399-403.

Fornari TA (2008) Análise da expressão gênica promíscua no timo de camundongos NOD (non obese diabetic) durante a emergência do diabetes melitus tipo 1. Dissertação de Mestrado, Faculdade de Medicina de Ribeirão Preto, USP (Orientador: Geraldo A. S. Passos).

Gallegos AM, Bevan MJ (2006). Central tolerance: good but imperfect. Immunol Rev. 209: 290-6.

Gardner TS, di Bernardo D, Lorenz D, Collins JJ (2003). Inferring genetic networks and identifying compound mode of action via expression profiling. Science 301(5629):102-5. 
Gatti D, Maki A, CheslerEJ, Kirova R, Kosyk O, Lu L, Manly KF, Williams RW, Perkins A, Langston MA, Threadgill DW, Rusyn I (2007). Genome-Level Analysis of Genetic Regulation of Liver Gene Expression Networks. Hepatology 46:548-557.

Germeraad WT, Kawamoto H, Itoi M, Jiang Y, Amagai T, Katsura Y, van Ewijk W. (2003). Development of thymic microenvironments in vitro is oxygendependent and requires permanent presence of T-cell progenitors. J Histochem Cytochem. 51(9):1225-35.

Gibson TJ, Ramu C, Gemund, C Aasland, R (1998). The APECED polyglandular autoimmune syndrome protein, AIRE-1, contains the SAND domain and is probably a transcription factor. Trends Biochem. Sci. 23, 242-244.

Gillard GO, Dooley J, Erickson M, Peltonen L, Farr AG (2007). Aire-dependent alterations in medullary thymic epithelium indicate a role for Aire in thymic epithelial differentiation. J Immunol. 178(5):3007-15.

Giraud M, Taubert R, Vandiedonck C, Ke X, Lévi-Strauss M, Pagani F, Baralle FE, Eymard B, Tranchant C, Gajdos P, Vincent A, Willcox N, Beeson D, Kyewski B, Garchon HJ (2007). An IRF8-binding promoter variant and AIRE control CHRNA1 promiscuous expression in thymus. Nature 448(7156):934-7.

Glaber J, Arnold J, Kyewski B (2007). Promiscuous gene expression and the developmental dynamics of medullary thymic epithelial cells. Eur. J. Immunol. 37: 3363-3372.

Gordon J, Bennett AR, Blackburn CC, Manley NR (2001). Gcm2 and Foxn1 mark early parathyroid- and thymus-specific domains in the developing third pharyngeal pouch. Mech Dev. 103(1-2):141-143.

Gordon J, Wilson VA, Blair NF, Sheridan J, Farley A, Wilson L, Manley NR, Blackburn CC. 2004 Functional evidence for a single endodermal origin for the thymic epithelium. Nat Immunol. 5(5):546-53. 
Gotter J, Brors B, Hergenhahn M, Kyewski B (2004). Medullary epithelial cells of the human thymus express a highly diverse selection of tissue-specific genes co-localized in chromosomal clusters. J. Exp. Med. 199(2): 155-166.

Gray DH, Ueno T, Chidgey AP, Malin M, Goldberg GL, Takahama Y, Boyd RL (2005). Controlling the thymic microenvironment. Curr Opin Immunol 17(2): 137-143.

Gray DH, Seach N, Ueno T, Milton MK, Liston A, Lew AM, Goodnow CC, Boyd RL (2006). Developmental kinetics, turnover, and stimulatory capacity of thymic epithelial cells. Blood. 108: 3777-3785.

Haks MC, Krimpenfort P, Borst J, Kruisbeek AM (1998). The CD3gamma chain is essential for development of both the TCR alpha beta and TCR gamma delta lineages. Embo 17(7): 1871-1882.

Harman BC, Jenkinson WE, Parnell SM, Rossi SW, Jenkinson EJ, Anderson G (2005). T/B lineage choice occurs prior to intrathymic Notch signaling. Blood 106(3):886-892.

Hartemink AJ (2005) Reverse engineering gene regulatory networks. Nature Biotechnology 23: 554-555.

Hedge P, Qi R, Abernathyk, Gay C, Dharap S, Gaspard R, Eaele-Hugues J, Snesrud E, Lee N, Quackenbush J (2000). A concise guide to cDNA microarray analysis. Biotechniques. 29(3):548-562.

Heino, M. Peterson P, Kudoh J, Nagamine K, Lagerstedt A, Ovod V, Ranki A, Rantala I, Nieminen M, Tuukkanen J, Scott HS, Antonarakis SE, Shimizu N, Krohn K (1999). Autoimmune regulator is expressed in the cells regulating immune tolerance in thymus medulla. Biochem. Biophys. Res. Commun. 257, 821-825.

Hollander GA (2007). Claudins provide a breath of fresh Aire. Nature Immunology 8(3)234-236.

Ilmarinen T, Kangas H, Kytömaa T, Eskelin P, Saharinen J, Seeler JS, Tanhuanpää K, Chan FY, Slattery RM, Alakurtti K, Palvimo JJ, Ulmanen I 
(2007). Functional interaction of AIRE with PIAS1 in transcriptional regulation. Mol. Immunol. [Epub ahead of print]

Itoi M, Kawamoto H, Katsura Y, Amagai T (2001). Two distinct steps of immigration of hematopoietic progenitors into the early thymus anlage. Int Immunol 13(9):1203-11.

Janknecht R, Hunter T (1996). Versatile molecular glue. Transcriptional control. Curr. Biol. 6:951-954.

Jenkinson WE, Jenkinson EJ, Anderson G (2003). Differential requirement for mesenchyme in the proliferation and maturation of thymic epithelial progenitors. J. Exp. Med. 198(2): 325-332.

Jolicoeur C, Hanahan D, Smith KM (1994). T-cell tolerance toward a transgenic B-cell antigen and transcription of endogenous pancreatic genes in thymus. Proc. Natl Acad. Sci. USA 91, 6707-6711.

Kim S, Kim J, Cho K (2007). Inferring gene regulatory networks from temporal expression profiles under time-delay and noise. Computational Biology and Chemistry. 31(4):239-45.

Kishimoto H, Sprent J (1997). Negative selection in the thymus includes semimature T cells. J. Exp. Med. 185: 263-271.

Klein L, Kyewski B (2000). Self-antigen presentation by thymic stromal cells: a subtle division of labor. Curr Opin Immunol. 12(2):179-86.

Kont V, Laan M, Kisand K, Merits A, Scottc HS, Peterson P (2008). Modulation of Aire regulates the expression of tissue-restricted antigens. Molecular Immunology 45(1): 25-33.

Kumar PG, Laloraya M, Wang C, Ruan Q, Davoodi-Semiromi A, Kao K, She J (2001). The autoimmune regulator (Aire) is a DNA binding protein. J. Biol. Chem. 276: 41357.

Kuroda N, Mitani T, Takeda N, Ishimaru N, Arakaki R, Hayashi Y, Bando Y, Izumi K, Takahashi T, Nomura T, Sakaguchi S, Ueno T, Takahama Y, Uchida D, Sun S, Kajiura F, Mouri Y, Han H, Matsushima A, Yamada G, 
Matsumoto M (2005). Development of autoimmunity against transcriptionally unrepressed target antigen in the thymus of Airedeficient mice. J. Immunol. 174, 18621870 (2005).

Kyewski B, Derbinski J, Gotter J, Klein L (2002). Promiscuous gene expression and central T-cell tolerance : more than meets the eye. Trends Immunol. 23: 364

Kyewski B, Derbinski J (2004). Self-representation in the thymus: an extended view. Nat Rev Immunol 4, 688-698.

Kyewski B, Klein L (2006). A central role for central tolerance. Annu. Rev. Immunol. 24: 571-606.

Leonard, M. (1946). Chronic idiopathic hypoparathyroidism with superimposed Addison's disease in a child. J. Clin. Endocrinol. Metab. 6, 493-495

Liston A, Lesage S, Wilson J, Peltonen L, Goodnow CC (2003). Aire regulates negative selection of organ-specific T cells. Nature Immunology 4(4):350-4.

Liston A, Gray DHD, Lesage S, Fletcher AL, Wilson J, Webster KE, Scott HS, Boyd RL, Peltonen L, Goodnow CC (2004). Gene Dosage-limiting Role of Aire in Thymic Expression, Clonal Deletion, and Organ-specific Autoimmunity. J. Exp. Med. 200 (8): 1015-1026.

Liiv I, Rebane A, Org T, Saare M, Maslovskaja J, Kisand K, Juronen E, Valmu L, Bottomley MJ, Kalkkinen N, Peterson P (2007). DNA-PK contributes to the phosphorylation of AIRE: Importance in transcriptional activity. Biochimica et Biophysica Acta 1783(1):74-83.

Lind EF, Prockop SE, Porritt HE, Petrie HT (2001). Mapping precursor movement through the postnatal thymus reveals specific microenvironments supporting defined stages of early lymphoid development. J. Exp. Med. 194, 127-134.

Magalhães DA, Silveira EL, Junta CM, Sandrin-Garcia P, Fachin AL, Donadi EA, Sakamoto-Hojo ET, Passos GA (2006). Promiscuous gene expression in the thymus: the root of central tolerance. Clin Dev Immunol.13(2-4):81-99. 
Manley NR. 2000 Thymus organogenesis and molecular mechanisms of thymic epithelial cell differentiation. Semin Immunol. 12(5):421-428.

Manley NR, Blackburn CC. 2003 A developmental look at thymus organogenesis: where do the non-hematopoietic cells in the thymus come from? Curr Opin Immunol. 15(2):225-32.

Margolin AA, Nemenman I, Basso K, Wiggins C, Stolovitzky G, Dalla Favera R, Califano A (2006) ARACNE: an algorithm for the reconstruction of gene regulatory networks in a mammalian cellular context. BMC Bioinformatics. 7 Suppl 1:S7.

Mathis D \& Benoist C (2007) A decade of AIRE. Nat Rev Immunol. 7(8):645-50.

Medzhitov R, Janeway CA (1997). Innate immunity, the virtues of a nonclonal system of recognition. Cell 91, 295-298.

Menossi M, Cremonese N, Maron LG, Arruda P (2000). Making colony PCR easier by adding gel-loading buffer to the amplification reaction. Biotechniques 28: 424-6.

Mizuochi T, Kasai M, Kokuho T, Kakiuchi T, Hirokawa K (1992). Medullary but not cortical thymic epithelial cells present soluble antigens to helper $\mathrm{T}$ cells. J. Exp. Med. 175: 1601-1605.

Montecino-Rodriquez E, Min H, Dorshkind K (2005). Reevaluating current models of thymic involution. Semin Immunol 17(5): 356-361.

Nagamine K, Peterson P, Scott HS, Kudoh J, Minoshima S, Heino M, Krohn KJ, Lalioti MD, Mullis PE, Antonarakis SE, Kawasaki K, Asakawa S, Ito F, Shimizu N (1997). Positional cloning of the APECED gene. Nature Genetics 17: 393-398.

Nagafuchi S, Katsuta H, Koyanagi-Katsuta R, Yamasaki S, Inoue Y, Shimoda K, Ikeda Y, Shindo M, Yoshida E, Matsuo T, Ohno Y, Kogawa K, Anzai K, Kurisaki H, Kudoh J, Harada M, Shimizu N (2006). Autoimmune regulator (AIRE) gene is expressed in human activated CD4+ T-cells and regulated 
by mitogen-activated protein kinase pathway. Microbiol Immunol. 50(12):979-87.

Nehls M, Kyewski B, Messerle M, Waldschütz R, Schüddekopf K, Smith AJ, Boehm T (1996). Two genetically separable steps in the differentiation of thymic epithelium. Science 272(5263):886-889.

Nguyen C, Rocha D, Granjeaud S, Baldit M, Bernard K, Naquet P, Jordan BR. (1995). Differential gene expression in the murine thymus assayed by quantitative hybridization of arrayed cDNA clones. Genomics 29(1):20716.

Nihei OK, Campos de Carvalho AC, Spray DC, Savino W, Alves LA (2003). A novel form of cellular communication among thymic epithelial cells: intercellular calcium wave propagation. Am J Physiol Cell Physiol. 285(5):C1304-13.

Niki S, Oshikawa K, Mouri Y, Hirota F, Matsushima A, Yano M, Han H, Bando Y, Izumi K, Matsumoto M, Nakayama KI, Kuroda N, Matsumoto M (2006). Alteration of intra-pancreatic target-organ specificity by abrogation of Aire in NOD mice. J. Clin. Invest. 116, 1292-1301.

Paula MO (2005) Interleucina 7 regula negativamente o desenvolvimento de células $\mathrm{T}$ e a expressão gênica de timos adultos em cultura (ATOC). Dissertação de Mestrado, Faculdade de Medicina de Ribeirão Preto, USP (Orientador: Geraldo A. S. Passos)

Paul WE (1993). Fundamental Immunology 3th Ed. Raven Press Ltd. New York.

Peterson P, Nagamine K, Scott H, Heino M, Kudoh J, Shimizu N, Antonarakis SE, Krohn KJ (1998). APECED: a monogenic autoimmune disease providing new clues to self-tolerance. Immunol.Today 19, 384-386.

Pietropaolo M, Giannoukakis N, Trucco M (2002). Cellular environment and freedom of gene expression. Nature Immunology 3(4):335. 
Pitkanen J, Doucas V, Sternsdorf T, Nakajima T, Aratani S, Jensen K, Will H, Vähämurto P, Ollila J, Vihinen M, Scott HS, Antonarakis SE, Kudoh J, Shimizu N, Krohn K, Peterson P (2000). The autoimmune regulator protein has transcriptional transactivating properties and interacts with the common coactivator CREB-binding protein. J Biol Chem. 275(22):16802-9.

Pitkanen J, Peterson P (2003). Autoimmune regulator : from loss of function to autoimmunity. Genes Immunology 4: 12.

Pitkänen J, Rebane A, Rowell J, Murumägi A, Ströbel P, Möll K, Saare M, Heikkilä J, Doucas V, Marx A, Peterson P (2005). Cooperative activation of transcription by autoimmune regulator AIRE and CBP. Biochem Biophys Res Commun. 333(3):944-53.

Pugliese A. (2002). Peripheral antigen-expressing cells and autoimmunity. Endocrinol Metab Clin North Am. 31(2):411-30.

Puthier D, Joly F, Irla M, Saade M, Victorero G, Loriod B, Nguyen C (2004). A general survey of thymocyte differentiation by transcriptional analysis of knockout mouse models. J Immunol. 173(10):6109-18.

Ramialison M, Mohr E, Nal B, Saboul T, Carrier A, Tagett R, Granjeaud S, Nguyen C, Gautheret D, Jordan BR, Ferrier P (2002). Expression profiling in mouse fetal thymus reveals clusters of coordinately expressed genes that mark individual stages of T-cell ontogeny. Immunogenetics. 54(7):469-478.

Ramsey C, Winqvist O, Puhakka L, Halonen M, Moro A, Kämpe O, Eskelin P, Pelto-Huikko M, Peltonen L (2002). Aire deficient mice develop multiple features of APECED phenotype and show altered immune response. Hum. Mol. Genet. 11, 397409.

Rossi SW, Jenkinson WE, Anderson G, Jenkinson EJ (2006). Clonal analysis reveals a common progenitor for thymic cortical and medullary epithelium. Nature 441(7096):988-991. 
Rossi SW, Kim MY, Leibbrandt A, Parnell SM, Jenkinson WE, Glanville SH, McConnell FM, Scott HS, Penninger JM, Jenkinson EJ, Lane PJ, Anderson G (2007). RANK signals from CD4(+)3(-) inducer cells regulate development of Aire-expressing epithelial cells in the thymic medulla. J Exp Med. 204(6):1267-72.

Sambrook J, Fritch EF, Maniats T (1989). Molecular cloning. A laboratory manual. Cold Spring Harbor Press. New York.

Savino W, Ayres Martins S, Neves-dos-Santos S, Smaniotto S, Ocampo JS, Mendes-da-Cruz DA, Terra-Granado E, Kusmenok O, Villa-Verde DM. (2003). Thymocyte migration: an affair of multiple cellular interactions? Braz J Med Biol Res. 36(8):1015-1025.

Savino W (2006). The Thymus Is a Common Target Organ in Infectious Diseases. PLoS Pathog 2(6):e62.

Savino W (2007). Neuroendocrine control of T cell development in mammals: role of growth hormone in modulating thymocyte migration. Exp Physiol. 92(5):813-817.

Silveira ELV (2005). Análise da expressão de genes de antígenos tecido específicos (TSAs) no timo de camundongos diabéticos não-obesos (NOD) usando cDNA microarrays. Dissertação de Mestrado, Faculdade de Medicina de Ribeirão Preto, USP (Orientador: Geraldo A. S. Passos).

Smyth GK (2004). Linear models and empirical Bayes methods for assessing differential expression in microarray experiments. Stat. Appl. Genet. Mol. Biol. 3.

Sousa Cardoso R, Magalhães DAR, Baião AMT, Junta CM, Macedo C, Marques MMC, Sakamoto-Hojo ET, Donadi EA, Passos GAS (2006). Onset of promiscuous gene expression in murine fetal organ culture. Immunology 119: 369-375.

Staudt LM, Brown PO (2000). Genomic view of the immune system. Annuv. Rev. Immunol. 18: 829-859. 
Strillacci A, Griffoni C, Spisni E, Manara MC, Tomasi V. (2006) RNA interference as a key to knockdown overexpressed cyclooxygenase-2 gene in tumour cells. Br J Cancer. 94(9):1300-10.

Su AI, Wiltshire T, Batalov S,Lapp H, Ching KA, Bock D, Zang J, Soden R, Hayakawa M, Kreiman G, Cooke MP, Walter JR, Hogenesch JB (2004). A gene atlas of the mouse and human protein-encoding transcriptomes. Proc. Natl. Acad. Sci. USA 101: 6062-6067.

Tabuchi Y, Takasaki I, Kondo T. (2006) Identification of genetic networks involved in the cell injury accompanying endoplasmic reticulum stress induced by bisphenol A in testicular Sertoli cells. Biochem Biophys Res Commun. 345(3): 1044-50.

Takahama, T. Journey through the thymus: stromal guides for T-cell development and selection. Nature Rev. Immunol. 6, 127-135 (2006).

Tao Y, Kupfer R, Stewart BJ, Williams-Skipp C, Crowell CK, Patel DD, Sain S, Scheinman RI (2006) AIRE recruits multiple transcriptional components to specific genomic regions through tethering to nuclear matrix. Molecular Immunology 43: 335-345.

Tegnér J, Yeung MKS, Hasty J, Collins JJ (2003). Reverse engineering gene networks: Integrating genetic pertubations with dynamical modeling. Proc. Natl. Acad. Sci, USA 100: 5944-5949.

Terszowski G, Müller SM, Bleul CC, Blum C, Schirmbeck R, Reimann J, Pasquier LD, Amagai T, Boehm T, Rodewald HR (2006) Evidence for a functional second thymus in mice. Science. 312(5771):284-287.

Tusher VG, Tibshirani R, Chu G (2001). Significance analysis of microarrays applied to the ionizing radiation response. Proc. Natl. Acad. Sci, USA 98 (9): 5116-5121.

van Ewijk W, Shores EW, Singer A (1994). Crosstalk in the mouse thymus. Immunol today 15:214-217.

van Ewijk W, Holländer G, Terhorst C, Wang B (2000). Stepwise development 
of thymic microenvironments in vivo is regulated by thymocyte subsets. Development 127(8): 1583-1591.

Venanzi ES, Gray DH, Benoist C, Mathis D (2007). Lymphotoxin pathway and Aire influences on thymic medullary epithelial cells are unconnected. J. Immunol. 179(9):5693-700.

Villa-Verde DM, Mello-Coelho V, Lagrota-Cândido JM, Chammas R, Savino W (1995). The thymic nurse cell complex: an in vitro model for extracellular matrix-mediated intrathymic $\mathrm{T}$ cell migration. Braz J Med Biol Res 28(8):907-12.

Yang YH, Speed TP (2002). Design issues for cDNA microarray experiments. Nature Rev. Genet. 3:579-588.

Yu J, Smith VA, Wang PP, Hartemink AJ, Jarvis ED (2004) Advances to bayesian network inference for generating causal networks from observational biological data. Bioinformatics 20: 3594-3603.

Walker LS, Abbas AK (2002). The enemy within: keeping self-reactive T cells at bay in the periphery. Nature Rev. Immunol. 2, 11-19.

Wang Y, Joshi T, Zhang XS, Xu D, Chen L (2006). Inferring gene regulatory networks from multiple microarray datasets. Bioinformatics 22: 2413-2420.

Wu CC, Huang HC, Juan HF, Chen, ST (2004). GeneNetwork: an interactive tool for reconstruction of genetic networks using microarray data. Bioinformatics 20(18): 3691-3.

Zamisch M, Moore-Scott B, Su DM, Lucas PJ, Manley NR, Richie ER (2005). Ontogeny and regulation of il-7-expressing thymic epithelial cells. J. Immunol. 174(1):60-67.

Zuklys S, Balciunaite G, Agarwal A, Fasler-Kan E, Palmer E, Holländer GA. (2000). Normal thymic architecture and negative selection are associated with Aire expression, the gene defective in the autoimmunepolyendocrinopathy-candidiasis-ectodermal dystrophy (APECED). J. Immunol. 165(4): 1976-1983. 
Zhu M, Chin RK, Christiansen PA, Lo JC, Liu X, Ware C, Siebenlist U, Fu YX (2006) NF-kB2 is required for the establishment of central tolerance through an Aire-dependent pathway. J. Clin. Invest. 116:2964-2971. 
Anexo I 
Tabela II. Genes diferencialmente expressos comparando-se os cinco grupos de células analisadas(FDR 5\%, p-value $\quad 0,005)$.

\begin{tabular}{|c|c|c|c|c|c|}
\hline Herc4 & IMAGE:583062 & Hect domain and RLD 4 & 0.20369264 & 0.33869174 & 5.28 \\
\hline EST & IMAGE:640001 & Expressed sequence tag & 0.19408871 & 0.33931252 & 4.84 \\
\hline Hnrpl & IMAGE:641039 & Heterogeneous nuclear ribonucleoprotein L & 0.48570776 & 0.3393502 & 4.84 \\
\hline Dock7 & IMAGE:583775 & Dedicator of cytokinesis 7 & 0.35370365 & 0.3394484 & 4.84 \\
\hline EST & IMAGE:583009 & Expressed sequence tag & 0.11662422 & 0.33949926 & 4.84 \\
\hline Btbd1 & IMAGE:582942 & BTB (POZ) domain containing 1 & 0.20342788 & 0.3395322 & 4.84 \\
\hline Txk & IMAGE:583533 & TXK tyrosine kinase & 0.05148377 & 0.3397727 & 4.84 \\
\hline Eml4 & IMAGE:577678 & $\begin{array}{l}\text { Echinoderm microtubule associated protein } \\
\text { like } 4\end{array}$ & 0.25414103 & 0.3398389 & 4.84 \\
\hline Sypl & IMAGE:640468 & Synaptophysin-like protein & 0.18131702 & 0.34053463 & 4.84 \\
\hline D030051D21 & IMAGE: 1226420 & Centrosomal protein 164 & 0.13844152 & 0.34055072 & 4.84 \\
\hline Setd8 & IMAGE:640985 & $\begin{array}{l}\text { SET domain containing (lysine } \\
\text { methyltransferase) } 8\end{array}$ & 0.1984913 & 0.34055364 & 4.84 \\
\hline EST & IMAGE:582875 & Expressed sequence tag & 0.33123899 & 0.3405946 & 4.84 \\
\hline EST & IMAGE:640180 & Expressed sequence tag & 0.17984709 & 0.34068993 & 4.84 \\
\hline Hspa14 & IMAGE:574381 & Heat shock protein 14 & 0.13240105 & 0.3408499 & 4.84 \\
\hline Iars2 & IMAGE:583626 & Isoleucine-tRNA synthetase 2 , mitochondrial & 0.20717484 & 0.34086606 & 4.84 \\
\hline Rab10 & IMAGE:573868 & RAB10, member RAS oncogene family & 0.18625002 & 0.34088877 & 4.84 \\
\hline
\end{tabular}




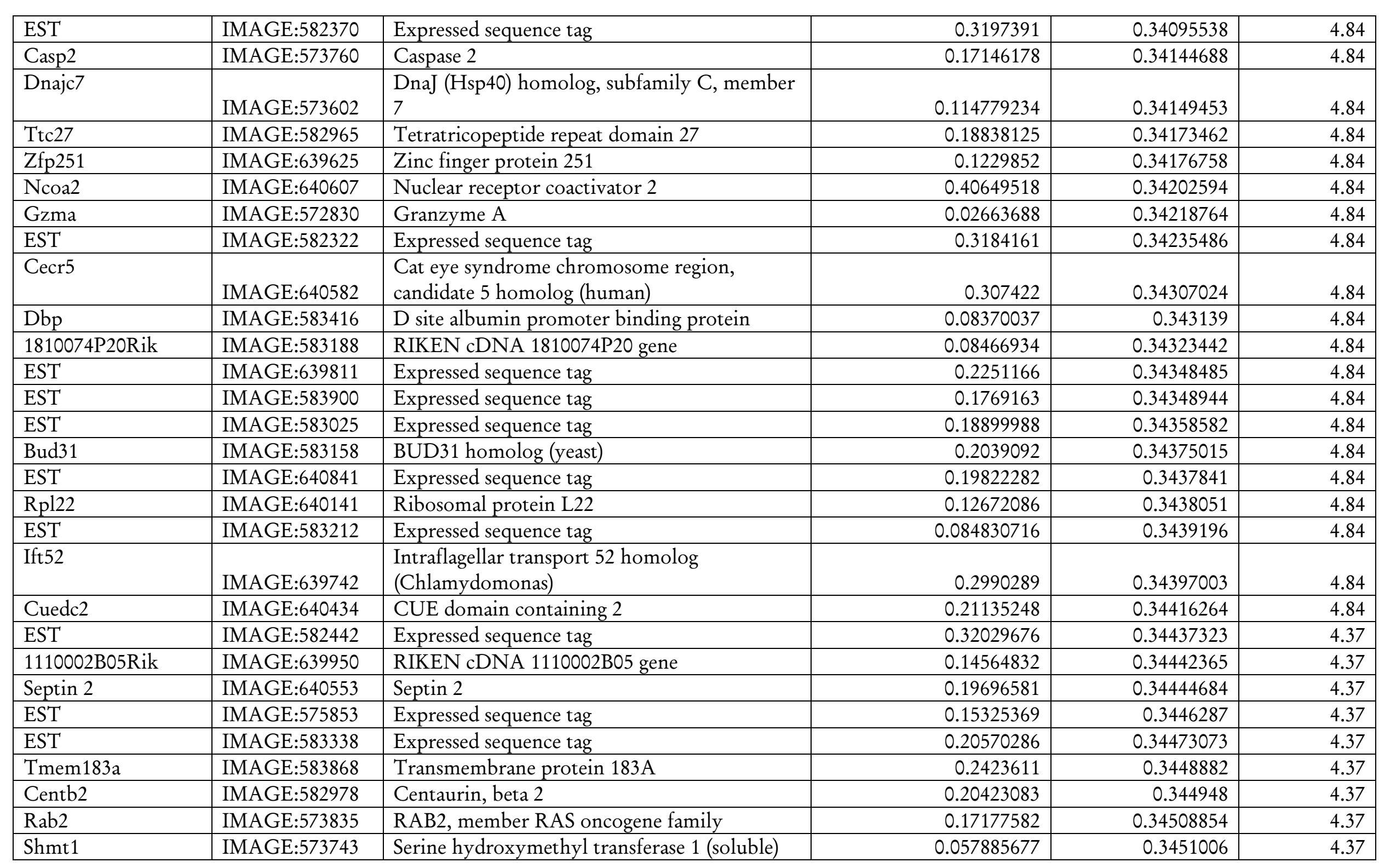


ANEXO I

\begin{tabular}{|c|c|c|c|c|c|}
\hline EST & IMAGE:583133 & Expressed sequence tag & 0.18863866 & 0.3455151 & 4.37 \\
\hline EST & IMAGE:640614 & Expressed sequence tag & 0.21096689 & 0.34611577 & 4.37 \\
\hline EST & IMAGE:573496 & Expressed sequence tag & 0.045981497 & 0.3463354 & 4.37 \\
\hline Ly9 & IMAGE:577717 & Lymphocyte antigen 9 & 0.23151654 & 0.34723872 & 4.37 \\
\hline Pias1 & IMAGE:577047 & Protein inhibitor of activated STAT 1 & 0.18718278 & 0.34730554 & 4.37 \\
\hline Rps20 & IMAGE:575123 & Ribosomal protein S20 & 0.28337494 & 0.3473207 & 4.37 \\
\hline BC031353 & IMAGE:583717 & CDNA sequence $\mathrm{BC} 031353$ & 0.1222328 & 0.34773922 & 4.37 \\
\hline EST & IMAGE:583293 & Expressed sequence tag & 0.26324844 & 0.3482185 & 4.37 \\
\hline Smg5 & IMAGE:582898 & $\begin{array}{l}\text { Smg-5 homolog, nonsense mediated mRNA } \\
\text { decay factor (C. elegans) }\end{array}$ & 0.28726238 & 0.3487496 & 4.08 \\
\hline Adcy7 & IMAGE:583381 & Adenylate cyclase 7 & 0.11992148 & 0.34893504 & 4.08 \\
\hline Btrc & IMAGE:639945 & Beta-transducin repeat containing protein & 0.2679437 & 0.34907925 & 4.08 \\
\hline EST & IMAGE:575632 & Expressed sequence tag & 0.13451812 & 0.35004562 & 4.08 \\
\hline Cdk4 & IMAGE:640626 & Cyclin-dependent kinase 4 & 0.21173468 & 0.3500662 & 4.08 \\
\hline EST & IMAGE:640399 & Expressed sequence tag & 0.22745329 & 0.35056454 & 4.08 \\
\hline Colba1 & IMAGE:1281632 & Procollagen, type VI, alpha 1 & 0.17330185 & 0.35064837 & 4.08 \\
\hline EST & IMAGE:641034 & Expressed sequence tag & 0.21294843 & 0.3506621 & 4.08 \\
\hline EST & IMAGE:640491 & Expressed sequence tag & 0.16514237 & 0.35066614 & 4.08 \\
\hline Atpaf1 & IMAGE:639636 & $\begin{array}{l}\text { ATP synthase mitochondrial F1 complex } \\
\text { assembly factor } 1\end{array}$ & 0.093742035 & 0.3509819 & 4.08 \\
\hline EST & IMAGE:640924 & Expressed sequence tag & 0.18304045 & 0.35103709 & 4.08 \\
\hline EST & IMAGE:583855 & Expressed sequence tag & 0.2227512 & 0.35148782 & 4.08 \\
\hline Lat & IMAGE:582840 & Linker for activation of T cells & 0.27982166 & 0.35173225 & 4.08 \\
\hline
\end{tabular}


ANEXO I

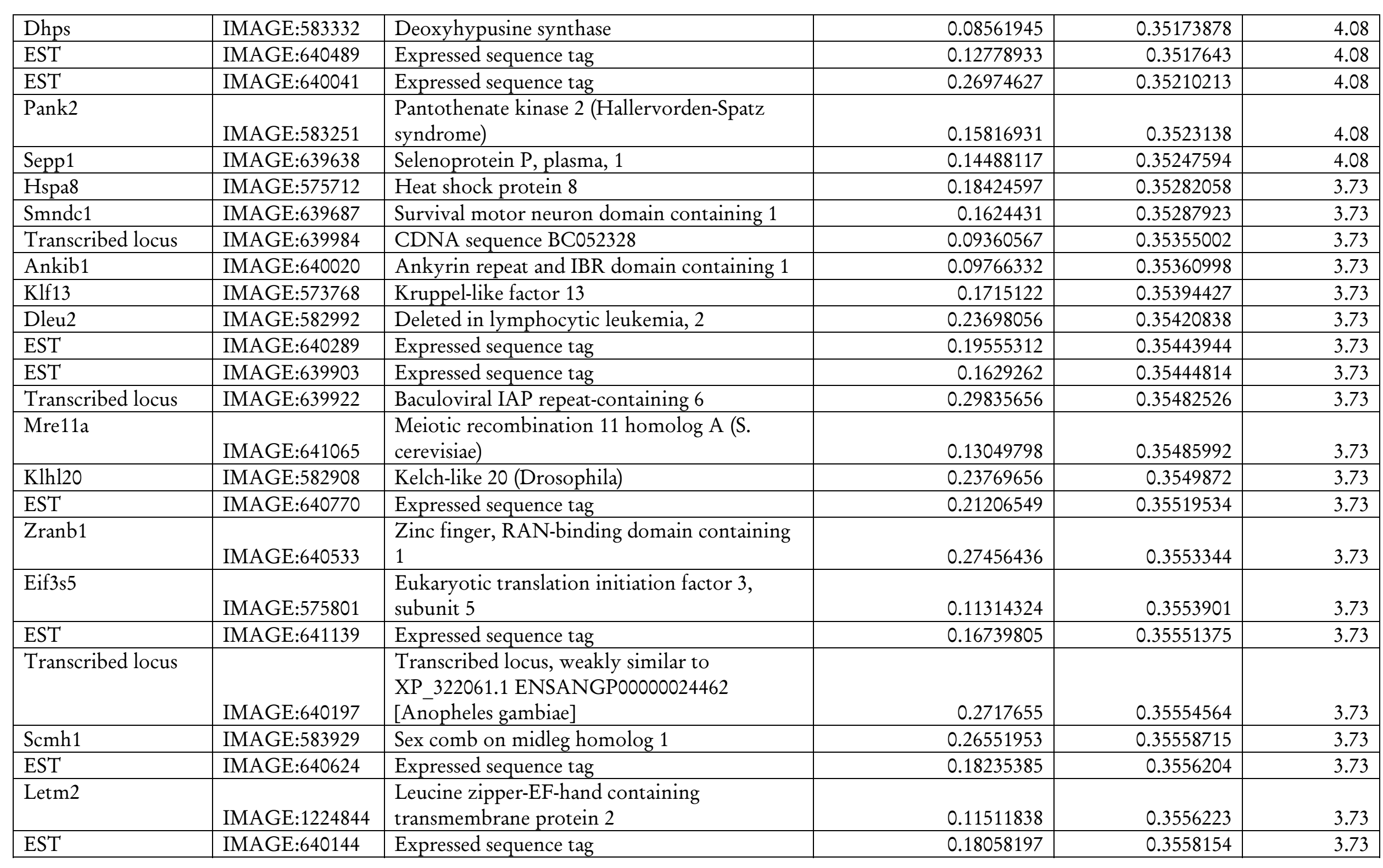




\begin{tabular}{|c|c|c|c|c|c|}
\hline EST & IMAGE:583777 & Expressed sequence tag & 0.121242285 & 0.3562752 & 3.73 \\
\hline Herc1 & IMAGE:583423 & $\begin{array}{l}\text { Hect (homologous to the E6-AP (UBE3A) } \\
\text { carboxyl terminus) domain and RCC1 } \\
\text { (CHC1)-like domain (RLD) } 1\end{array}$ & 0.22075455 & 0.35633478 & 3.73 \\
\hline Ap3d1 & IMAGE:573056 & $\begin{array}{l}\text { Adaptor-related protein complex } 3 \text {, delta } 1 \\
\text { subunit }\end{array}$ & 0.07284064 & 0.35687634 & 3.44 \\
\hline In multiple clusters & IMAGE:639506 & Expressed sequence tag & 0.28487006 & 0.3569772 & 3.44 \\
\hline Edar & IMAGE:3661299 & Ectodysplasin-A receptor & 0.28670955 & 0.3571688 & 3.44 \\
\hline EST & IMAGE:639948 & Expressed sequence tag & 0.09538322 & 0.35730532 & 3.44 \\
\hline EST & IMAGE:582360 & Expressed sequence tag & 0.31916782 & 0.35732123 & 3.44 \\
\hline EST & IMAGE:583048 & Expressed sequence tag & 0.17435218 & 0.35736024 & 3.44 \\
\hline Transcribed locus & IMAGE:639657 & $\begin{array}{l}\text { Transcribed locus, strongly similar to } \\
\text { NP_848844.1 and leucine-rich repeat protein } 5 \\
\text { [Mus musculus] }\end{array}$ & 0.26698583 & 0.3584844 & 3.44 \\
\hline In multiple clusters & IMAGE:573897 & Expressed sequence tag & 0.106632546 & 0.35959485 & 3.44 \\
\hline Man2b1 & IMAGE:640168 & Mannosidase 2, alpha B1 & 0.1806364 & 0.35970306 & 3.44 \\
\hline EST & IMAGE:640943 & Expressed sequence tag & 0.46805397 & 0.3600849 & 3.44 \\
\hline EST & IMAGE:640939 & Expressed sequence tag & 0.23051128 & 0.36065164 & 3.44 \\
\hline Pgam5 & IMAGE:640720 & Phosphoglycerate mutase family member 5 & 0.18256535 & 0.360898 & 3.15 \\
\hline Mapk9 & IMAGE:583487 & Mitogen activated protein kinase 9 & 0.3448025 & 0.36091268 & 3.15 \\
\hline 2210404O07Rik & IMAGE:573122 & RIKEN cDNA $2210404 \mathrm{O} 07$ gene & 0.11244351 & 0.36114112 & 3.15 \\
\hline BC002199 & IMAGE:583821 & CDNA sequence BC002199 & 0.26647037 & 0.36150783 & 3.15 \\
\hline EST & IMAGE:639675 & Expressed sequence tag & 0.16157694 & 0.36193871 & 3.15 \\
\hline Socs1 & IMAGE:582855 & Suppressor of cytokine signaling 1 & 0.15766856 & 0.36274025 & 3.15 \\
\hline EST & IMAGE:640613 & Expressed sequence tag & 0.19628459 & 0.3628432 & 3.15 \\
\hline
\end{tabular}




\begin{tabular}{|c|c|c|c|c|c|}
\hline Mapkapk2 & IMAGE:572979 & MAP kinase-activated protein kinase 2 & 0.036123693 & 0.36288625 & 3.15 \\
\hline Myg1 & IMAGE:583514 & Melanocyte proliferating gene 1 & 0.1409242 & 0.36304536 & 3.15 \\
\hline EST & IMAGE:639725 & Expressed sequence tag & 0.19273359 & 0.36314243 & 3.15 \\
\hline Rab2 & IMAGE:573835 & RAB2, member RAS oncogene family & 0.10643569 & 0.3633285 & 3.15 \\
\hline E530011L22Rik & IMAGE:583156 & RIKEN cDNA E530011L22 gene & 0.17414281 & 0.36366665 & 3.15 \\
\hline Il16 & IMAGE:573050 & Interleukin 16 & 0.039014325 & 0.3649915 & 2.91 \\
\hline Dnajb7 & IMAGE:1263299 & $\begin{array}{l}\text { DnaJ (Hsp40) homolog, subfamily B, member } \\
7\end{array}$ & 0.15621331 & 0.3650117 & 2.91 \\
\hline Hint1 & IMAGE:583258 & Histidine triad nucleotide binding protein 1 & 0.28990576 & 0.3653645 & 2.91 \\
\hline EST & IMAGE:640033 & Expressed sequence tag & 0.12527369 & 0.3654705 & 2.91 \\
\hline EST & IMAGE:640344 & Expressed sequence tag & 0.0974249 & 0.36594763 & 2.91 \\
\hline LOC100039015 & IMAGE:640715 & $\begin{array}{l}\text { Similar to Unknown (protein for } \\
\text { MGC:117841) }\end{array}$ & 0.39596888 & 0.36676776 & 2.91 \\
\hline EST & IMAGE:640766 & Expressed sequence tag & 0.14945124 & 0.3670429 & 2.91 \\
\hline Bcl11b & IMAGE:576116 & Transcribed locus & 0.18465409 & 0.36709076 & 2.91 \\
\hline In multiple clusters & IMAGE:581967 & Expressed sequence tag & 0.21751688 & 0.3671049 & 2.91 \\
\hline Rcor1 & IMAGE:575972 & REST corepressor 1 & 0.15359582 & 0.3674069 & 2.91 \\
\hline Rab28 & IMAGE:1328024 & RAB28, member RAS oncogene family & 0.18774924 & 0.36742395 & 2.91 \\
\hline 1500034J01Rik & IMAGE:640967 & RIKEN cDNA 1500034J01 gene & 0.47321466 & 0.36755872 & 2.91 \\
\hline EST & IMAGE:583506 & Expressed sequence tag & 0.20608248 & 0.3678798 & 2.91 \\
\hline EST & IMAGE:640274 & Expressed sequence tag & 0.14646642 & 0.36792225 & 2.91 \\
\hline Gfm2 & IMAGE:640159 & G elongation factor, mitochondrial 2 & 0.22601599 & 0.36802432 & 2.91 \\
\hline
\end{tabular}




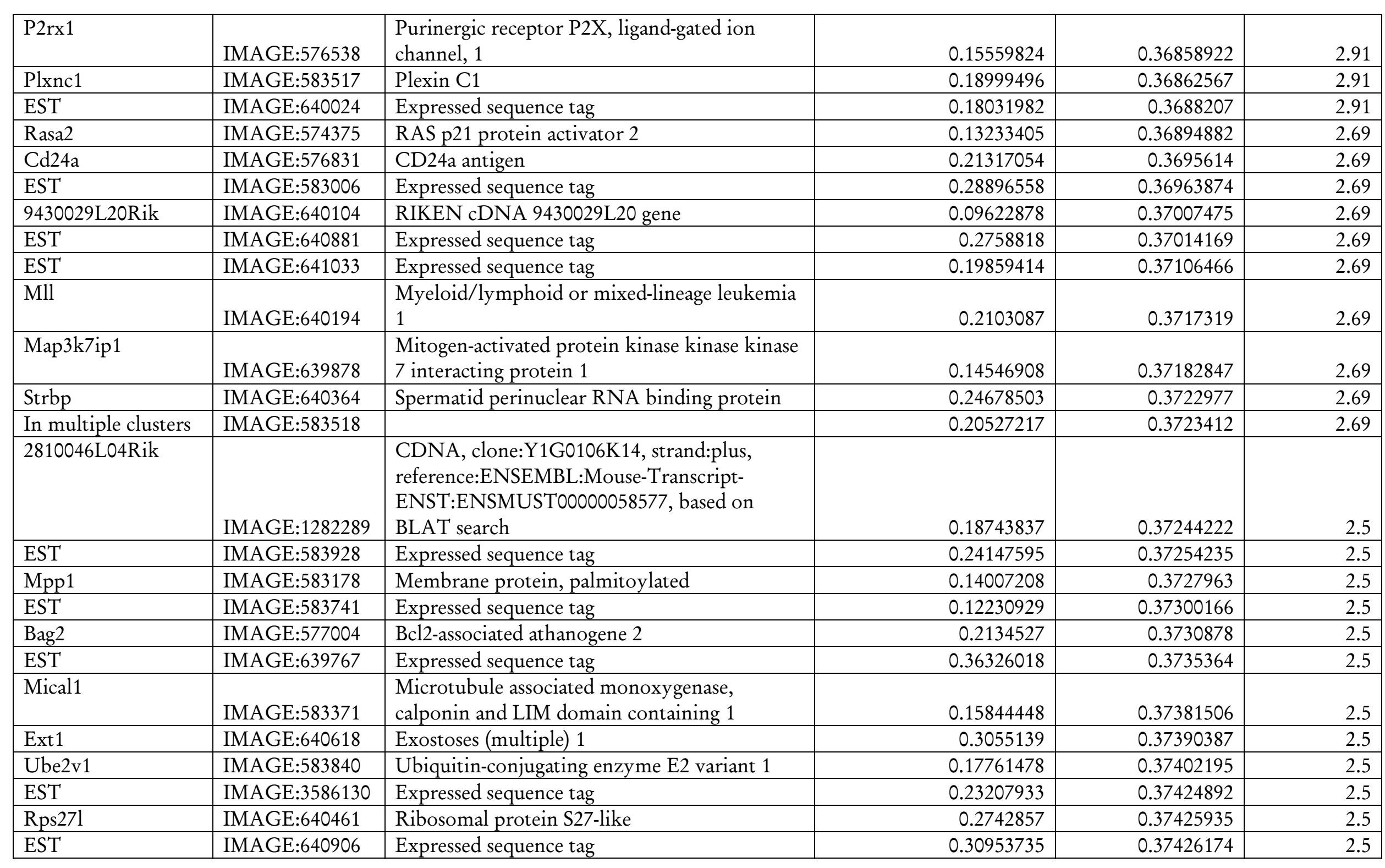




\begin{tabular}{|c|c|c|c|c|c|}
\hline Gm608 & IMAGE:583350 & Gene model 608 & 0.20488659 & 0.37445837 & 2.5 \\
\hline EST & IMAGE:640814 & Expressed sequence tag & 0.15042305 & 0.3744847 & 2.5 \\
\hline Csnk1a1 & IMAGE:641129 & Casein kinase 1, alpha 1 & 0.19881043 & 0.37483838 & 2.5 \\
\hline EST & IMAGE:583244 & Expressed sequence tag & 0.23954351 & 0.37575468 & 2.5 \\
\hline MSR1 & IMAGE:4453348 & Macrophage scavenger receptor 1 & 0.15398371 & 0.3759334 & 2.5 \\
\hline EST & IMAGE:640977 & Expressed sequence tag & 0.27625927 & 0.3765886 & 2.26 \\
\hline D4Wsu53e & IMAGE:583562 & $\begin{array}{l}\text { DNA segment, Chr 4, Wayne State University } \\
53 \text {, expressed }\end{array}$ & 0.14204179 & 0.37683904 & 2.26 \\
\hline Rps6kb1 & IMAGE:583236 & Ribosomal protein S6 kinase, polypeptide 1 & 0.08499483 & 0.37691882 & 2.26 \\
\hline EST & IMAGE:640589 & Expressed sequence tag & 0.19622897 & 0.37704912 & 2.26 \\
\hline Cbx3 & IMAGE:583742 & $\begin{array}{l}\text { Chromobox homolog } 3 \text { (Drosophila HP1 } \\
\text { gamma) }\end{array}$ & 0.14337903 & 0.37713507 & 2.26 \\
\hline EST & IMAGE:583340 & Expressed sequence tag & 0.23981206 & 0.3778922 & 2.26 \\
\hline EST & IMAGE:640812 & Expressed sequence tag & 0.10454907 & 0.3780873 & 2.26 \\
\hline Fau & IMAGE:1328685 & $\begin{array}{l}\text { Finkel-Biskis-Reilly murine sarcoma virus } \\
\text { (FBR-MuSV) ubiquitously expressed (fox } \\
\text { derived) }\end{array}$ & 0.18785195 & 0.37815145 & 2.26 \\
\hline Tcrg-C & IMAGE:640129 & T-cell receptor gamma, constant region & 0.12556937 & 0.37820753 & 2.26 \\
\hline Gtpbp6 & IMAGE:640177 & GTP binding protein 6 (putative) & 0.1257116 & 0.3785117 & 2.26 \\
\hline EST & IMAGE:576406 & Expressed sequence tag & 0.20004235 & 0.3785163 & 2.26 \\
\hline Sec3111 & IMAGE:583334 & SEC31 homolog A (S. cerevisiae) & 0.1414248 & 0.3789015 & 2.26 \\
\hline Nol14 & IMAGE:1447151 & Nucleolar protein 14 & 0.25879025 & 0.379031 & 2.26 \\
\hline EST & IMAGE:640840 & Expressed sequence tag & 0.18356669 & 0.37930754 & 2.26 \\
\hline
\end{tabular}


ANEXO I

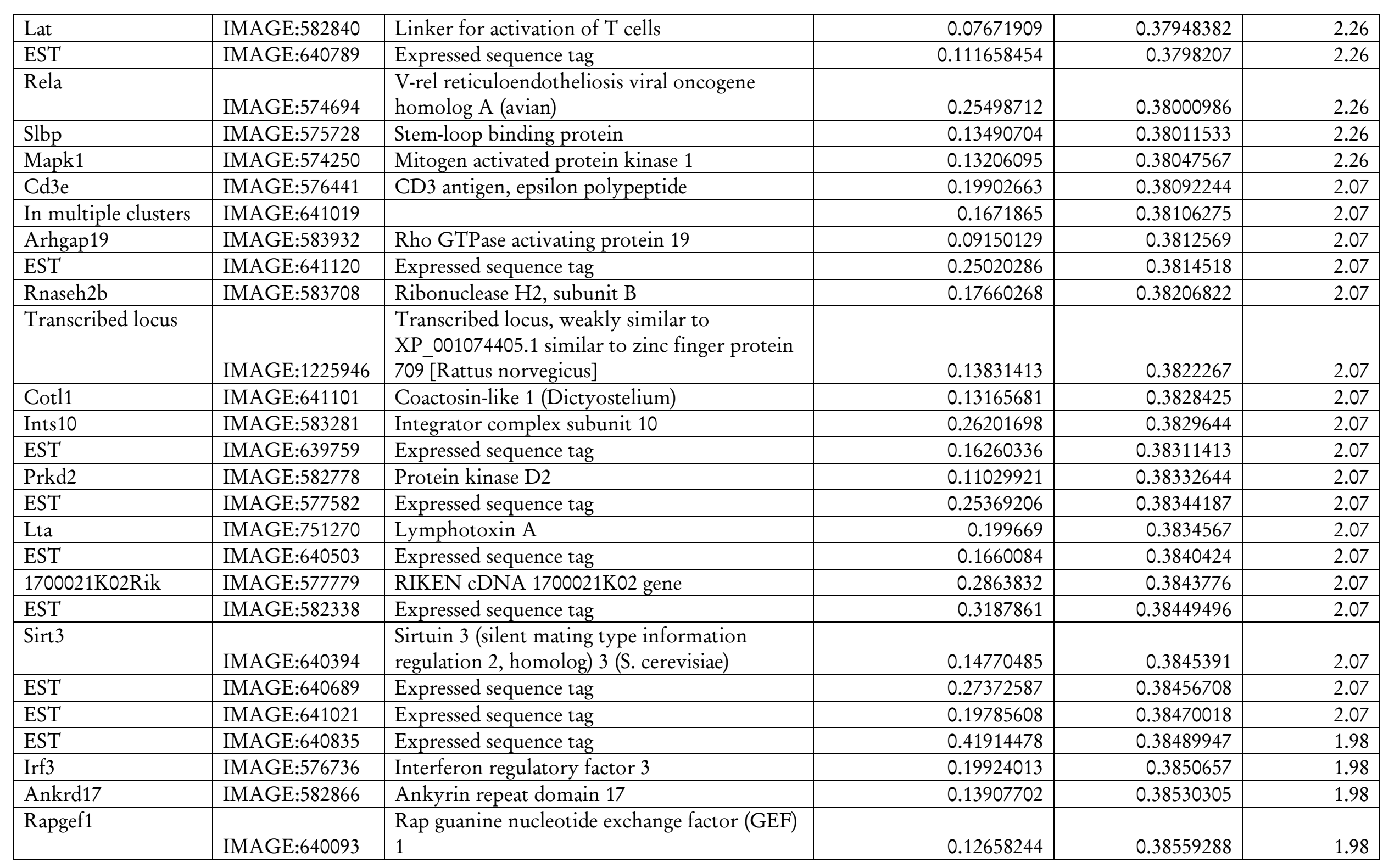




\begin{tabular}{|c|c|c|c|c|c|}
\hline Ccdc72 & IMAGE:640628 & Coiled-coil domain containing 72 & 0.24869469 & 0.38605982 & 1.98 \\
\hline Wfikkn2 & IMAGE:583320 & $\begin{array}{l}\text { WAP, follistatin/kazal, immunoglobulin, } \\
\text { kunitz and netrin domain containing } 2\end{array}$ & 0.08301636 & 0.3860893 & 1.98 \\
\hline Il12rb1 & IMAGE:582118 & Interleukin 12 receptor, beta 1 & 0.2813599 & 0.3863084 & 1.98 \\
\hline In multiple clusters & IMAGE:640200 & Expressed sequence tag & 0.09672052 & 0.38694626 & 1.98 \\
\hline EST & IMAGE:639899 & Expressed sequence tag & 0.3596155 & 0.3869807 & 1.98 \\
\hline Prrg2 & IMAGE:640686 & $\begin{array}{l}\text { Proline-rich Gla (G-carboxyglutamic acid) } \\
\text { polypeptide } 2\end{array}$ & 0.2111313 & 0.38747868 & 1.98 \\
\hline EST & IMAGE:640644 & Expressed sequence tag & 0.10230052 & 0.3881982 & 1.98 \\
\hline Spna2 & IMAGE:583512 & Spectrin alpha 2 & 0.084340475 & 0.3881995 & 1.98 \\
\hline Gcc2 & IMAGE:575478 & GRIP and coiled-coil domain containing 2 & 0.06938428 & 0.38822982 & 1.98 \\
\hline A630034I12Rik & IMAGE:640302 & RIKEN cDNA A630034I12 gene & 0.20980926 & 0.38826653 & 1.98 \\
\hline Cxcl14 & IMAGE:583442 & Chemokine (C-X-C motif) ligand 14 & 0.14074096 & 0.3884111 & 1.98 \\
\hline EST & IMAGE:640564 & Expressed sequence tag & 0.18151987 & 0.38856086 & 1.98 \\
\hline EST & IMAGE:640598 & Expressed sequence tag & 0.14904618 & 0.3891659 & 1.77 \\
\hline 5830405N20Rik & IMAGE:583659 & RIKEN cDNA 5830405N20 gene & 0.15998822 & 0.38950008 & 1.77 \\
\hline Transcribed locus & IMAGE:639941 & Transcribed locus & 0.19315057 & 0.39022473 & 1.77 \\
\hline Calm1 & IMAGE:577674 & Calmodulin 1 & 0.21678129 & 0.39035785 & 1.77 \\
\hline Ly6d & IMAGE:581909 & Lymphocyte antigen 6 complex, locus D & 0.25690898 & 0.39068517 & 1.77 \\
\hline EST & IMAGE:583299 & Expressed sequence tag & 0.1582784 & 0.39118844 & 1.77 \\
\hline EST & IMAGE:640796 & Expressed sequence tag & 0.13543391 & 0.39150044 & 1.77 \\
\hline EST & IMAGE:641012 & Expressed sequence tag & 0.25102594 & 0.3915085 & 1.77 \\
\hline EST & IMAGE:1281355 & Expressed sequence tag & 0.17314598 & 0.39151922 & 1.77 \\
\hline DCLRE1C & IMAGE:1743667 & $\begin{array}{l}\text { DNA cross-link repair 1C (PSO2 homolog, S. } \\
\text { cerevisiae) }\end{array}$ & 0.21400993 & 0.3916138 & 1.77 \\
\hline
\end{tabular}




\begin{tabular}{|c|c|c|c|c|c|}
\hline Tpr & IMAGE:576622 & Translocated promoter region & 0.21503003 & 0.39219284 & 1.77 \\
\hline Transcribed locus & IMAGE:574942 & Transcribed locus & 0.2826275 & 0.39224002 & 1.77 \\
\hline Rhoa & IMAGE:583485 & Ras homolog gene family, member A & 0.2639187 & 0.39250165 & 1.77 \\
\hline EST & IMAGE:640376 & RIKEN cDNA 4930432K21 gene & 0.24573953 & 0.39331234 & 1.64 \\
\hline Zfp131 & IMAGE:572856 & Zinc finger protein 131 & 0.06827795 & 0.39385924 & 1.64 \\
\hline Nkx6-2 & IMAGE:576409 & $\begin{array}{l}\text { NK6 transcription factor related, locus } 2 \\
\text { (Drosophila) }\end{array}$ & 0.15520824 & 0.39392173 & 1.64 \\
\hline Cox17 & IMAGE:583452 & $\begin{array}{l}\text { Cytochrome c oxidase, subunit XVII assembly } \\
\text { protein homolog (yeast) }\end{array}$ & 0.08636887 & 0.3945485 & 1.64 \\
\hline Ly6e & IMAGE:640890 & Lymphocyte antigen 6 complex, locus $\mathrm{E}$ & 0.133406 & 0.39520568 & 1.64 \\
\hline EST & IMAGE:640654 & Expressed sequence tag & 0.30787432 & 0.39615345 & 1.64 \\
\hline EST & IMAGE:581675 & Expressed sequence tag & 0.32438198 & 0.3968295 & 1.51 \\
\hline Fasl & IMAGE:3417263 & Fas ligand (TNF superfamily, member 6) & 0.17109413 & 0.39707422 & 1.51 \\
\hline Pkp1 & IMAGE:583760 & Plakophilin 1 & 0.24099706 & 0.39757895 & 1.51 \\
\hline EST & IMAGE:640904 & Expressed sequence tag & 0.24955747 & 0.3979872 & 1.51 \\
\hline EST & IMAGE:582858 & Expressed sequence tag & 0.20406908 & 0.39799318 & 1.51 \\
\hline Exdl2 & IMAGE:640270 & Exonuclease 3"'-5" domain-like 2 & 0.30362678 & 0.39818573 & 1.51 \\
\hline EST & IMAGE:639734 & Expressed sequence tag & 0.1451156 & 0.39847633 & 1.51 \\
\hline Klhdc5 & IMAGE:640756 & Kelch domain containing 5 & 0.18193711 & 0.39860782 & 1.51 \\
\hline EST & IMAGE:583699 & Expressed sequence tag & 0.22328195 & 0.39863968 & 1.51 \\
\hline $\mathrm{Mxd} 4$ & IMAGE:640190 & Max dimerization protein 4 & 0.14717604 & 0.3988511 & 1.51 \\
\hline Clec1b & IMAGE:574821 & C-type lectin domain family 1, member b & 0.15156524 & 0.39935553 & 1.51 \\
\hline Transcribed locus & IMAGE:640165 & Transcribed locus & 0.12679222 & 0.39939374 & 1.51 \\
\hline Cys1 & IMAGE:582804 & Cystin 1 & 0.07945655 & 0.39942518 & 1.51 \\
\hline
\end{tabular}




\begin{tabular}{|c|c|c|c|c|c|}
\hline Transcribed locus & IMAGE:582892 & $\begin{array}{l}\text { Transcribed locus, moderately similar to } \\
\text { XP_001103164.1 similar to 60S ribosomal } \\
\text { protein L12 [Macaca mulatta] }\end{array}$ & 0.17361486 & 0.40003896 & 1.51 \\
\hline EST & IMAGE:583695 & Expressed sequence tag & 0.1608681 & 0.4003079 & 1.51 \\
\hline Ccdc58 & IMAGE:582929 & Coiled-coil domain containing 58 & 0.18879382 & 0.4011698 & 1.37 \\
\hline Btg2 & IMAGE:639859 & B-cell translocation gene 2, anti-proliferative & 0.22523461 & 0.4013058 & 1.37 \\
\hline Taf15 & IMAGE:639860 & $\begin{array}{l}\text { TAF15 RNA polymerase II, TATA box } \\
\text { binding protein (TBP)-associated factor }\end{array}$ & 0.24421383 & 0.4013146 & 1.37 \\
\hline Uqcrfs1 & IMAGE:640752 & $\begin{array}{l}\text { Ubiquinol-cytochrome c reductase, Rieske } \\
\text { iron-sulfur polypeptide } 1\end{array}$ & 0.101116255 & 0.40176198 & 1.37 \\
\hline Dhrs13 & IMAGE:576046 & $\begin{array}{l}\text { Dehydrogenase/reductase (SDR family) } \\
\text { member } 13\end{array}$ & 0.11375762 & 0.4019725 & 1.37 \\
\hline Fyb & IMAGE:1264938 & Prohibitin & 0.17272258 & 0.40204743 & 1.37 \\
\hline Rpain & IMAGE:573267 & RPA interacting protein & 0.13627423 & 0.40244517 & 1.37 \\
\hline Clec14a & IMAGE:576574 & C-type lectin domain family 14, member a & 0.21469185 & 0.40293807 & 1.37 \\
\hline Arpc3 & IMAGE:640677 & Actin related protein $2 / 3$ complex, subunit 3 & 0.2750277 & 0.40315855 & 1.37 \\
\hline EST & IMAGE:640868 & Expressed sequence tag & 0.2505796 & 0.40386733 & 1.37 \\
\hline EST & IMAGE:640319 & Expressed sequence tag & 0.38339138 & 0.404027 & 1.37 \\
\hline EST & IMAGE:583103 & Expressed sequence tag & 0.33644107 & 0.4041983 & 1.37 \\
\hline EST & IMAGE:640173 & Expressed sequence tag & 0.1080738 & 0.4047628 & 1.26 \\
\hline C77370 & IMAGE:583793 & Expressed sequence C77370 & 0.19215246 & 0.40533575 & 1.26 \\
\hline 5330438D12Rik & IMAGE:640084 & RIKEN cDNA 5330438D12 gene & 0.17964597 & 0.40572393 & 1.26 \\
\hline EST & IMAGE:583673 & Expressed sequence tag & 0.1918779 & 0.40591183 & 1.26 \\
\hline Arntl & IMAGE:582931 & $\begin{array}{l}\text { Aryl hydrocarbon receptor nuclear } \\
\text { translocator-like }\end{array}$ & 0.21954234 & 0.4060044 & 1.26 \\
\hline
\end{tabular}




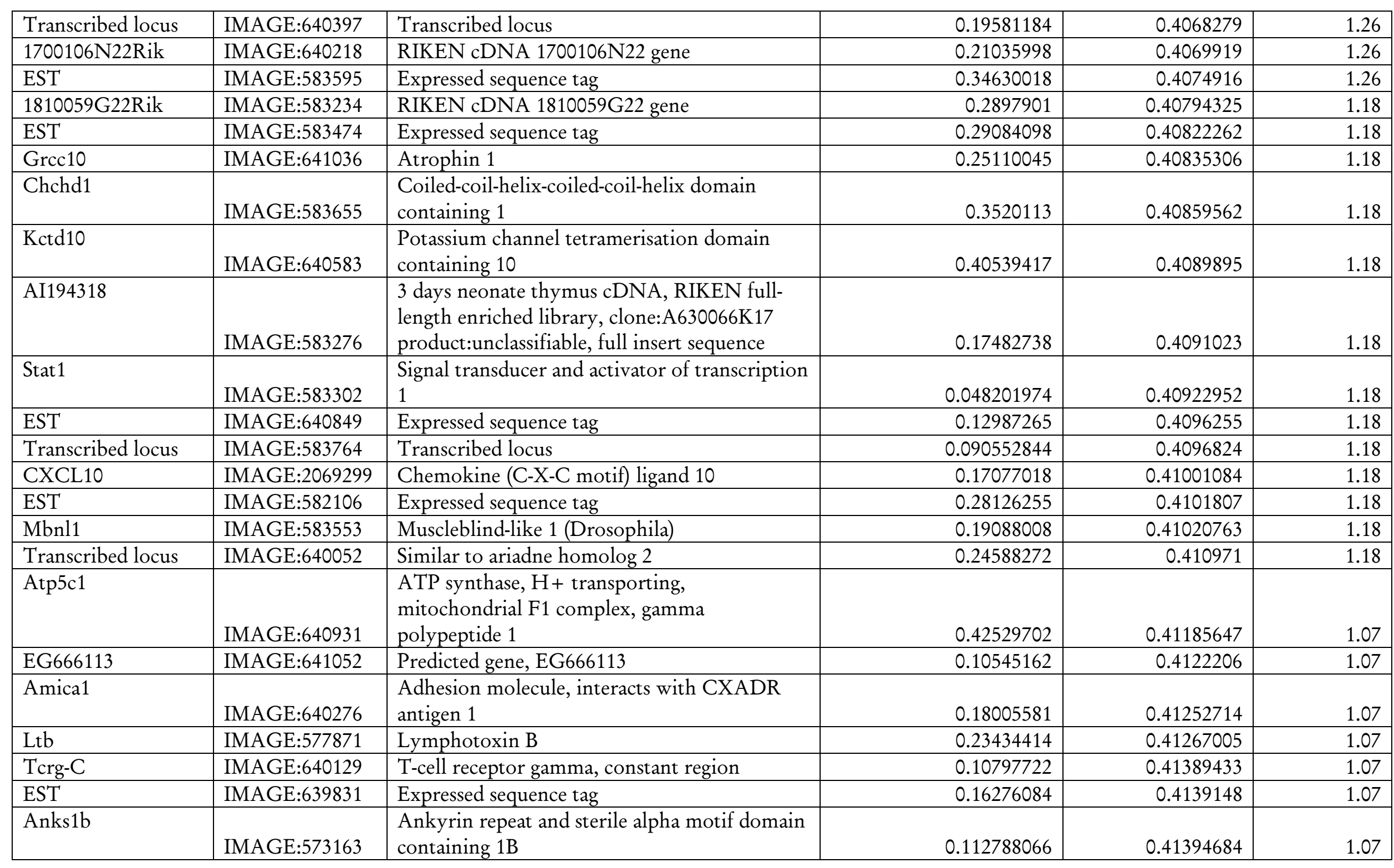


ANEXO I

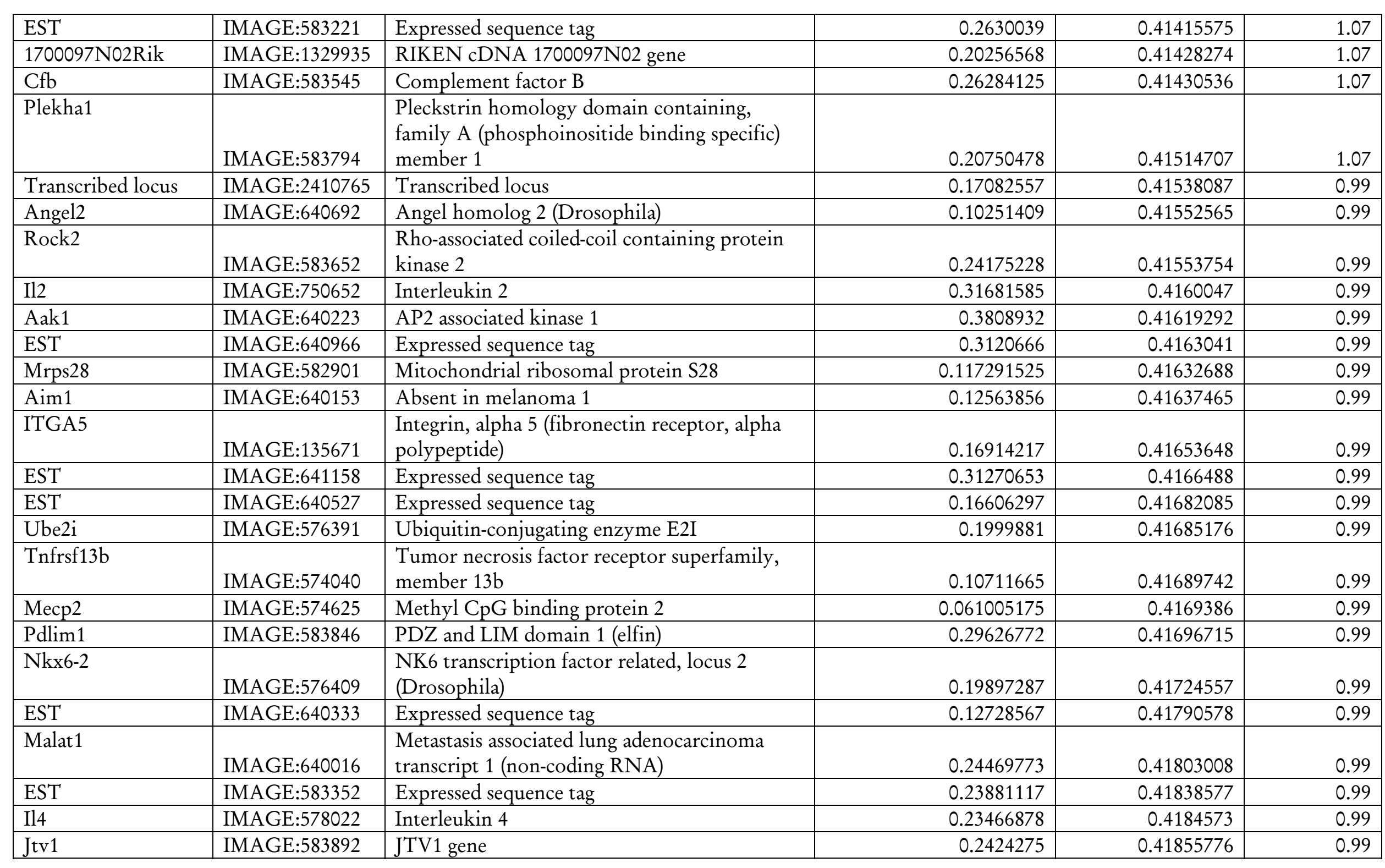




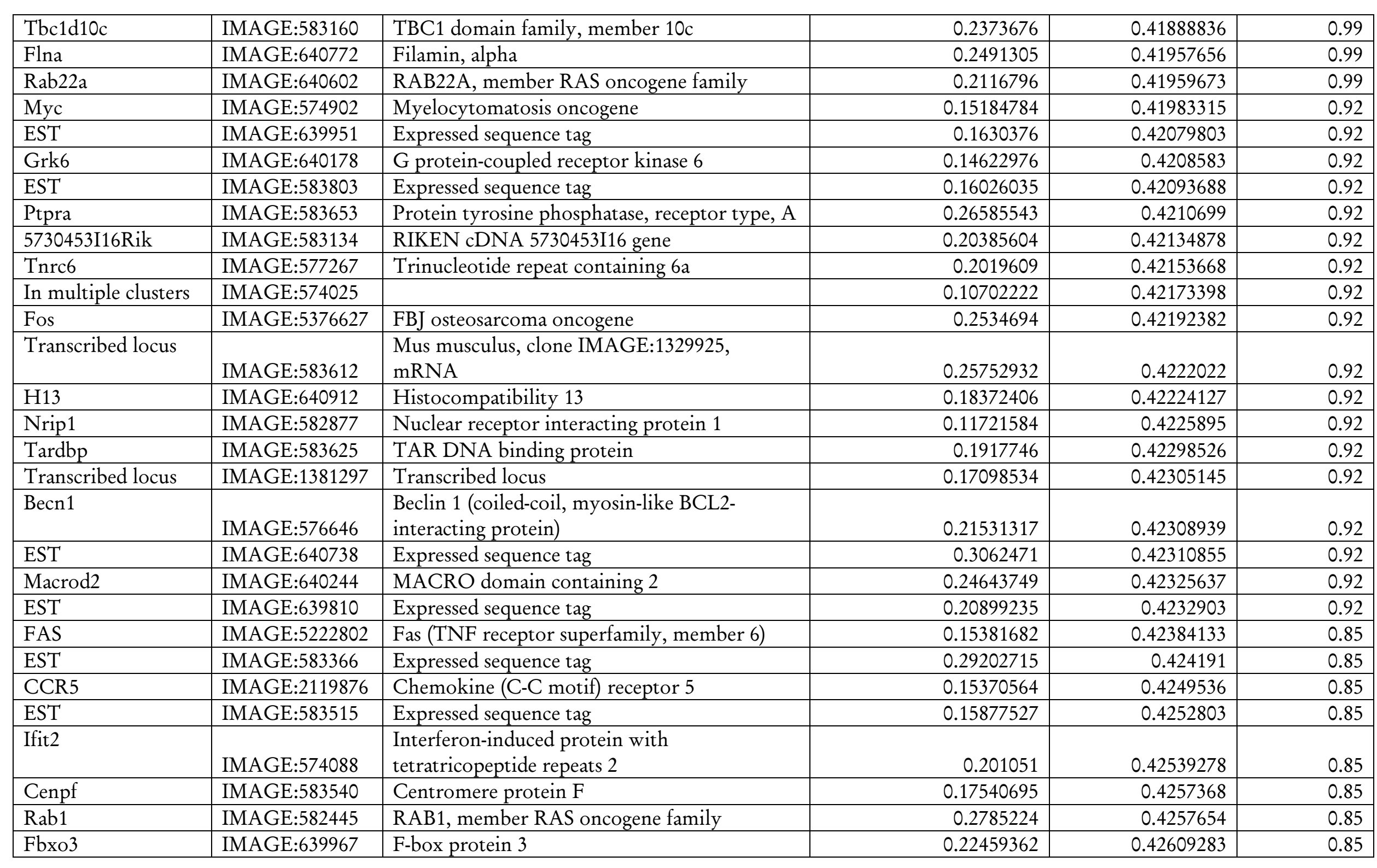




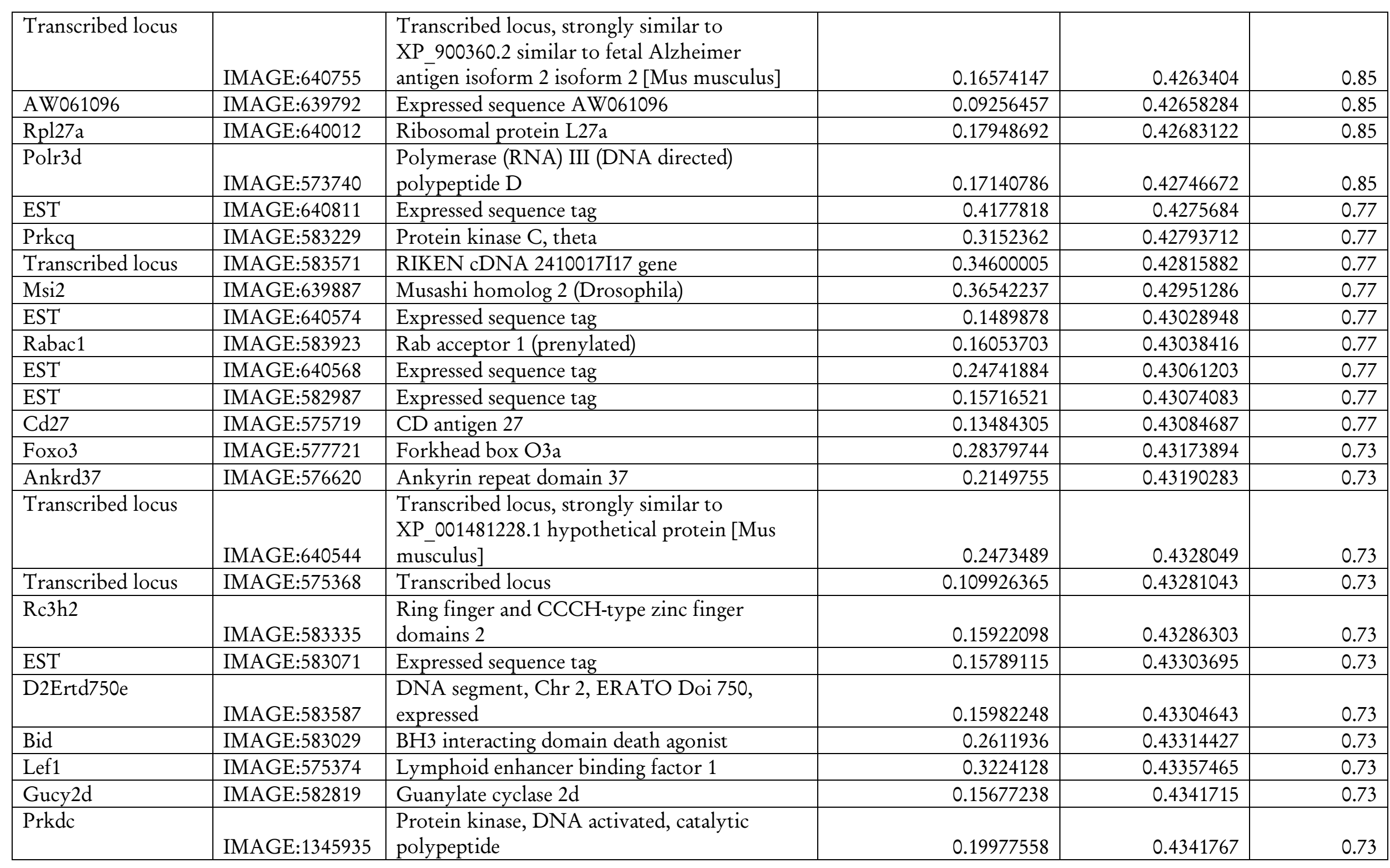




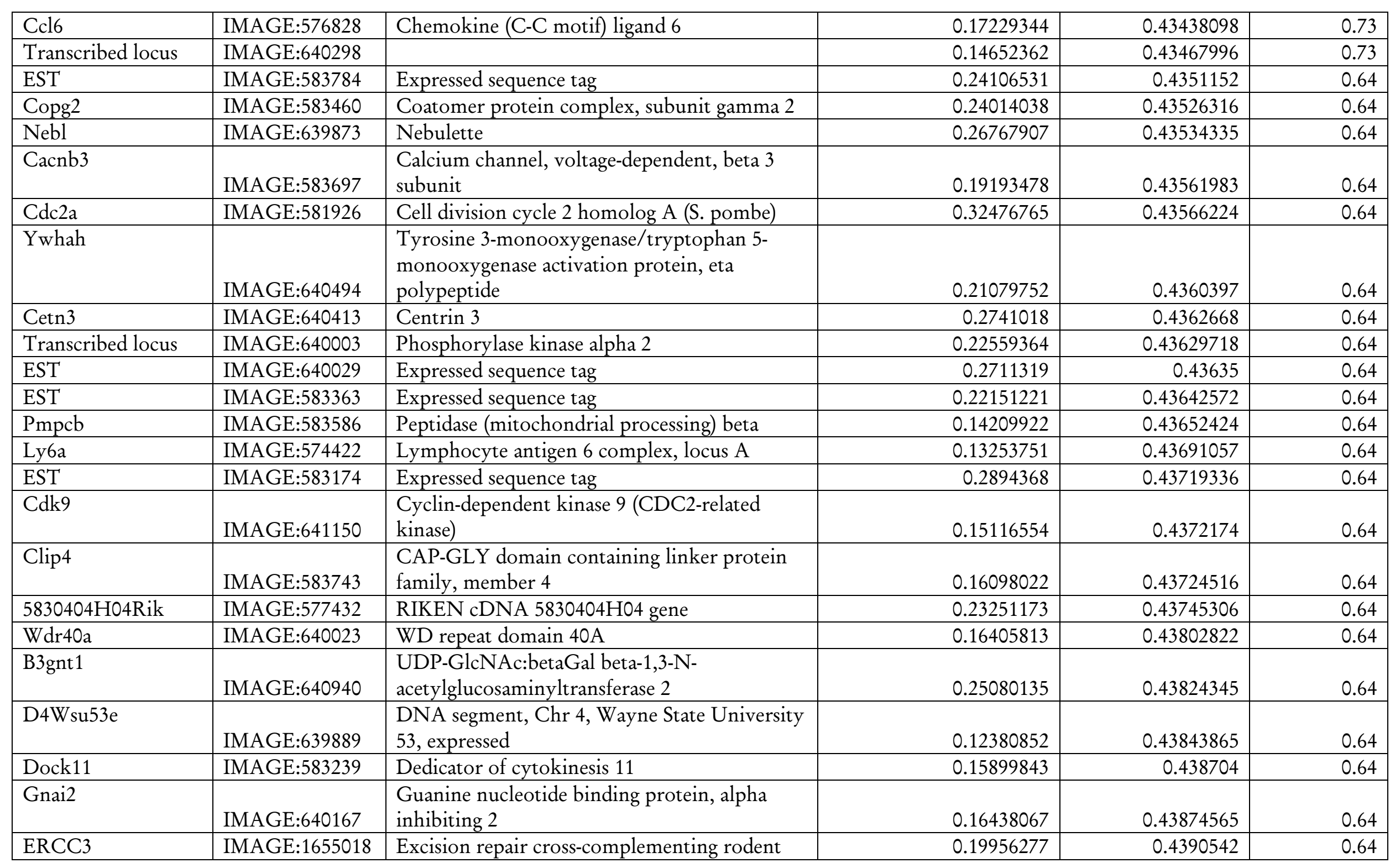




\begin{tabular}{|c|c|c|c|c|c|}
\hline & & $\begin{array}{l}\text { repair deficiency, complementation group } 3 \\
\text { (xeroderma pigmentosum group B } \\
\text { complementing) }\end{array}$ & & & \\
\hline Fdx1 & IMAGE:583500 & Ferredoxin 1 & 0.086673975 & 0.4390946 & 0.64 \\
\hline EST & IMAGE:640419 & Expressed sequence tag & 0.16497816 & 0.4394148 & 0.61 \\
\hline Itsn2 & IMAGE:583881 & Intersectin 2 & 0.26534885 & 0.43961382 & 0.61 \\
\hline TLR4 & IMAGE:6047339 & Toll-like receptor 4 & 0.15409493 & 0.43962702 & 0.61 \\
\hline Grlf1 & IMAGE:640573 & Glucocorticoid receptor DNA binding factor 1 & 0.12905097 & 0.4396407 & 0.61 \\
\hline Ccdc41 & IMAGE:639929 & RIKEN cDNA 4921537D05 gene & 0.19393376 & 0.44014138 & 0.61 \\
\hline Suz12 & IMAGE:640237 & Suppressor of zeste 12 homolog (Drosophila) & 0.12700497 & 0.44020954 & 0.61 \\
\hline EST & IMAGE:641111 & Expressed sequence tag & 0.51701295 & 0.4404906 & 0.61 \\
\hline EST & IMAGE:640047 & Expressed sequence tag & 0.16411279 & 0.44056523 & 0.61 \\
\hline In multiple clusters & IMAGE:574076 & & 0.107304975 & 0.44075873 & 0.61 \\
\hline In multiple clusters & IMAGE:577750 & & 0.25468263 & 0.44120133 & 0.61 \\
\hline EST & IMAGE:639660 & Expressed sequence tag & 0.10750361 & 0.44263285 & 0.61 \\
\hline Mrpl3 & IMAGE:583898 & Mitochondrial ribosomal protein L3 & 0.14282548 & 0.44307244 & 0.61 \\
\hline EST & IMAGE:583688 & Expressed sequence tag & 0.2407978 & 0.4431002 & 0.61 \\
\hline 1110006G06Rik & IMAGE:582920 & RIKEN cDNA 1110006G06 gene & 0.23678574 & 0.44330415 & 0.61 \\
\hline EST & IMAGE:640866 & Expressed sequence tag & 0.2126287 & 0.44408375 & 0.52 \\
\hline EST & IMAGE:640431 & Expressed sequence tag & 0.16584426 & 0.44449207 & 0.52 \\
\hline Il18rap & IMAGE:640615 & Interleukin 18 receptor accessory protein & 0.1331393 & 0.44458842 & 0.52 \\
\hline $\mathrm{Cxcl} 4$ & IMAGE:573339 & Chemokine (C-X-C motif) ligand 4 & 0.043369222 & 0.4449553 & 0.52 \\
\hline EST & IMAGE:583780 & Expressed sequence tag & 0.17675592 & 0.44537395 & 0.52 \\
\hline Atg2b & IMAGE:640202 & $\begin{array}{l}\text { ATG2 autophagy related } 2 \text { homolog B (S. } \\
\text { cerevisiae) }\end{array}$ & 0.14629018 & 0.44544846 & 0.52 \\
\hline
\end{tabular}




\begin{tabular}{|c|c|c|c|c|c|}
\hline Sdc1 & IMAGE:577122 & Syndecan 1 & 0.21361962 & 0.44550738 & 0.52 \\
\hline Ostf1 & IMAGE:641061 & Osteoclast stimulating factor 1 & 0.2779244 & 0.44555533 & 0.52 \\
\hline D10Wsu102e & IMAGE:583685 & $\begin{array}{l}\text { DNA segment, Chr 10, Wayne State } \\
\text { University 102, expressed }\end{array}$ & 0.19114035 & 0.4459335 & 0.52 \\
\hline EST & IMAGE:582250 & Expressed sequence tag & 0.28209364 & 0.44596457 & 0.52 \\
\hline EST & IMAGE:640449 & Expressed sequence tag & 0.27278548 & 0.44724146 & 0.53 \\
\hline AI481772 & IMAGE:583909 & Expressed sequence AI481772 & 0.12283737 & 0.4475117 & 0.53 \\
\hline Hook3 & IMAGE:640124 & Hook homolog 3 (Drosophila) & 0.24609293 & 0.44875866 & 0.53 \\
\hline Rragc & IMAGE:640581 & Ras-related GTP binding C & 0.27475202 & 0.44900617 & 0.53 \\
\hline EST & IMAGE:640360 & Expressed sequence tag & 0.18105556 & 0.44908473 & 0.53 \\
\hline VEGFA & IMAGE:34778 & Vascular endothelial growth factor A & 0.15252505 & 0.44951892 & 0.53 \\
\hline EST & IMAGE:583096 & Expressed sequence tag & 0.17440337 & 0.44983044 & 0.53 \\
\hline Pcnt & IMAGE:640026 & Pericentrin (kendrin) & 0.20997316 & 0.4500112 & 0.53 \\
\hline 2610209M04Rik & IMAGE:640363 & RIKEN cDNA 2610209M04 gene & 0.22733416 & 0.45204553 & 0.49 \\
\hline Cd83 & IMAGE:574651 & CD83 antigen & 0.15128258 & 0.45249233 & 0.49 \\
\hline TGFB1 & IMAGE:136821 & $\begin{array}{l}\text { Transforming growth factor, beta } 1 \text { (Camurati- } \\
\text { Engelmann disease) }\end{array}$ & 0.16908714 & 0.45257518 & 0.49 \\
\hline Ep400 & IMAGE:639900 & E1A binding protein $\mathrm{p} 400$ & 0.09512772 & 0.45283258 & 0.49 \\
\hline Evl & IMAGE:582896 & Ena-vasodilator stimulated phosphoprotein & 0.23671931 & 0.4530029 & 0.49 \\
\hline Gm237 & IMAGE:639696 & Gene model 237, (NCBI) & 0.09202822 & 0.45314112 & 0.49 \\
\hline Il4 & IMAGE:574369 & Interleukin 4 & 0.21605256 & 0.453198 & 0.49 \\
\hline EST & IMAGE:576452 & & 0.20019776 & 0.45330137 & 0.49 \\
\hline 2310035C23Rik & IMAGE:573037 & RIKEN cDNA 2310035C23 gene & 0.11218727 & 0.4534347 & 0.49 \\
\hline Nr4a1 & IMAGE:582922 & Nuclear receptor subfamily 4 , group A, & 0.2873756 & 0.4536512 & 0.49 \\
\hline
\end{tabular}




\begin{tabular}{|c|c|c|c|c|c|}
\hline & & member 1 & & & \\
\hline EST & IMAGE:583824 & Expressed sequence tag & 0.088761464 & 0.4540717 & 0.49 \\
\hline $\mathrm{Cd} 4$ & IMAGE:640273 & CD4 antigen & 0.108447455 & 0.4543197 & 0.49 \\
\hline Ppp2ca & IMAGE:581653 & $\begin{array}{l}\text { Protein phosphatase } 2 \text { (formerly 2A), catalytic } \\
\text { subunit, alpha isoform }\end{array}$ & 0.21711949 & 0.455006 & 0.44 \\
\hline Btbd1 & IMAGE:640060 & BTB (POZ) domain containing 1 & 0.17958812 & 0.4552251 & 0.44 \\
\hline IRAK2 & IMAGE:4450379 & Interleukin-1 receptor-associated kinase 2 & 0.15387209 & 0.45648474 & 0.44 \\
\hline EST & IMAGE:640783 & Expressed sequence tag & 0.111119255 & 0.45692128 & 0.44 \\
\hline 1200014M14Rik & IMAGE:583885 & RIKEN cDNA $1200014 \mathrm{M} 14$ gene & 0.122763 & 0.45700908 & 0.44 \\
\hline EST & IMAGE:582514 & Expressed sequence tag & 0.06277903 & 0.45704105 & 0.44 \\
\hline Pkp3 & IMAGE:583696 & Plakophilin 3 & 0.17729883 & 0.45723903 & 0.44 \\
\hline Fbxo34 & IMAGE:1362061 & F-box protein 34 & 0.21797502 & 0.4580247 & 0.44 \\
\hline $\mathrm{Cd} 24 \mathrm{a}$ & IMAGE:576831 & CD24a antigen & 0.17234898 & 0.45846042 & 0.44 \\
\hline Nup50 & IMAGE:639698 & Nucleoporin 50 & 0.14409864 & 0.45861965 & 0.44 \\
\hline Bptf & IMAGE:583596 & $\begin{array}{l}\text { Bromodomain PHD finger transcription } \\
\text { factor }\end{array}$ & 0.089597665 & 0.45881146 & 0.44 \\
\hline 2410018C17Rik & IMAGE:640132 & RIKEN cDNA 2410018C17 gene & 0.1797458 & 0.4588168 & 0.44 \\
\hline Transcribed locus & IMAGE:581923 & $\begin{array}{l}\text { Transcribed locus, moderately similar to } \\
\text { XP_001096337.1 similar to } 60 \mathrm{kDa} \text { heat shock } \\
\text { protein, mitochondrial precursor (Hsp60) (60 } \\
\mathrm{kDa} \text { chaperonin) (CPN60) (Heat shock } \\
\text { protein 60) (HSP-60) (Mitochondrial matrix } \\
\text { protein P1) (P60 lymphocyte protein) }\end{array}$ & 0.25213364 & 0.45904043 & 0.44 \\
\hline
\end{tabular}


ANEXO I

\begin{tabular}{|c|c|c|c|c|c|}
\hline & & (HuCHA60) [Macaca mulatta] & & & \\
\hline AI316807 & IMAGE:575276 & Expressed sequence AI316807 & 0.10928467 & 0.45915985 & 0.44 \\
\hline EST & IMAGE:639723 & Expressed sequence tag & 0.16168493 & 0.45930547 & 0.44 \\
\hline Hivep2 & IMAGE:1282235 & $\begin{array}{l}\text { Human immunodeficiency virus type I } \\
\text { enhancer binding protein } 2\end{array}$ & 0.17335606 & 0.45987818 & 0.4 \\
\hline In multiple clusters & IMAGE:640263 & & 0.3268622 & 0.45998484 & 0.4 \\
\hline Il5 & IMAGE:972705 & Interleukin 5 & 0.1993991 & 0.46035945 & 0.4 \\
\hline EST & IMAGE:582312 & Expressed sequence tag & 0.31806487 & 0.46052033 & 0.4 \\
\hline EST & IMAGE:640393 & Expressed sequence tag & 0.1275003 & 0.46071306 & 0.4 \\
\hline Tfam & IMAGE:1329916 & Transcription factor A, mitochondrial & 0.20251001 & 0.46080697 & 0.4 \\
\hline Ptp4a3 & IMAGE:583209 & Protein tyrosine phosphatase $4 \mathrm{a} 3$ & 0.26177517 & 0.46132147 & 0.4 \\
\hline EST & IMAGE:641020 & Expressed sequence tag & 0.18325152 & 0.4620093 & 0.4 \\
\hline Ppp2r5e & IMAGE:640259 & $\begin{array}{l}\text { Protein phosphatase } 2 \text {, regulatory subunit B } \\
\text { (B56), epsilon isoform }\end{array}$ & 0.37304685 & 0.4642693 & 0.36 \\
\hline EST & IMAGE:640373 & Expressed sequence tag & 0.19492763 & 0.46454036 & 0.36 \\
\hline Lypla1 & IMAGE:641132 & Lysophospholipase 1 & 0.25139084 & 0.4656194 & 0.36 \\
\hline EST & IMAGE:640785 & Expressed sequence tag & 0.27550352 & 0.46572915 & 0.36 \\
\hline D14Ertd449e & IMAGE:640010 & Placenta specific 9 & 0.14582492 & 0.46619272 & 0.36 \\
\hline Ide & IMAGE:574949 & Insulin degrading enzyme & 0.15190135 & 0.46653748 & 0.36 \\
\hline EST & IMAGE:583462 & Expressed sequence tag & 0.29250666 & 0.46668932 & 0.36 \\
\hline Sec24c & IMAGE:640591 & $\begin{array}{l}\text { SEC24 related gene family, member C (S. } \\
\text { cerevisiae) }\end{array}$ & 0.22793202 & 0.46680376 & 0.36 \\
\hline Capn2 & IMAGE:575158 & Calpain 2 & 0.108809896 & 0.4668477 & 0.36 \\
\hline
\end{tabular}


ANEXO I

\begin{tabular}{|c|c|c|c|c|c|}
\hline Transcribed locus & IMAGE:583004 & Transcribed locus & 0.23788959 & 0.46791652 & 0.31 \\
\hline TLR9 & IMAGE:5495717 & Toll-like receptor 9 & 0.15432386 & 0.4679352 & 0.31 \\
\hline TLR2 & IMAGE:4753177 & Toll-like receptor 2 & 0.15421213 & 0.4686194 & 0.31 \\
\hline Hdlbp & IMAGE:640671 & $\begin{array}{l}\text { High density lipoprotein (HDL) binding } \\
\text { protein }\end{array}$ & 0.16637671 & 0.47082257 & 0.31 \\
\hline Insl5 & IMAGE:575182 & Insulin-like 5 & 0.15201358 & 0.47085735 & 0.31 \\
\hline Ube1x & IMAGE:575553 & Ubiquitin-activating enzyme E1, Chr X & 0.13445424 & 0.47157744 & 0.31 \\
\hline Tpp1 & IMAGE:641000 & Tripeptidyl peptidase I & 0.24984907 & 0.471742 & 0.31 \\
\hline Nrbf2 & IMAGE:583296 & Nuclear receptor binding factor 2 & 0.0474979 & 0.47185194 & 0.31 \\
\hline Zfp213 & IMAGE:583538 & Zinc finger protein 213 & 0.14098835 & 0.47202215 & 0.31 \\
\hline Rbm18 & IMAGE:640326 & RNA binding motif protein 18 & 0.20986354 & 0.47325337 & 0.31 \\
\hline Taf3 & IMAGE:640587 & $\begin{array}{l}\text { TAF3 RNA polymerase II, TATA box } \\
\text { binding protein (TBP)-associated factor }\end{array}$ & 0.16535634 & 0.4735352 & 0.31 \\
\hline HSPD1 & IMAGE:133099 & $\begin{array}{l}\text { Transcribed locus, weakly similar to } \\
\text { XP_360622.1 protein MG03165.4 } \\
\text { [Magnaporthe grisea } 70-15]\end{array}$ & 0.16903718 & 0.47474864 & 0.26 \\
\hline Gtf2b & IMAGE:640038 & General transcription factor IIB & 0.20932186 & 0.47519597 & 0.26 \\
\hline EST & IMAGE:640895 & Expressed sequence tag & 0.45987147 & 0.47538242 & 0.26 \\
\hline EST & IMAGE:583447 & Expressed sequence tag & 0.22081181 & 0.4754048 & 0.26 \\
\hline EST & IMAGE:640717 & Expressed sequence tag & 0.12945664 & 0.47556496 & 0.26 \\
\hline BC036313 & IMAGE:639985 & CDNA sequence $\mathrm{BC} 036313$ & 0.12410744 & 0.47563264 & 0.26 \\
\hline Pdha1 & IMAGE:583224 & Pyruvate dehydrogenase E1 alpha 1 & 0.082349576 & 0.47570455 & 0.26 \\
\hline $\mathrm{Tdg}$ & IMAGE:642198 & Thymine DNA glycosylase & 0.11503782 & 0.4759388 & 0.26 \\
\hline $\mathrm{Cd} 300 \mathrm{~d}$ & IMAGE:582766 & $\mathrm{Cd} 300 \mathrm{D}$ antigen & 0.2796216 & 0.47678146 & 0.26 \\
\hline
\end{tabular}


ANEXO I

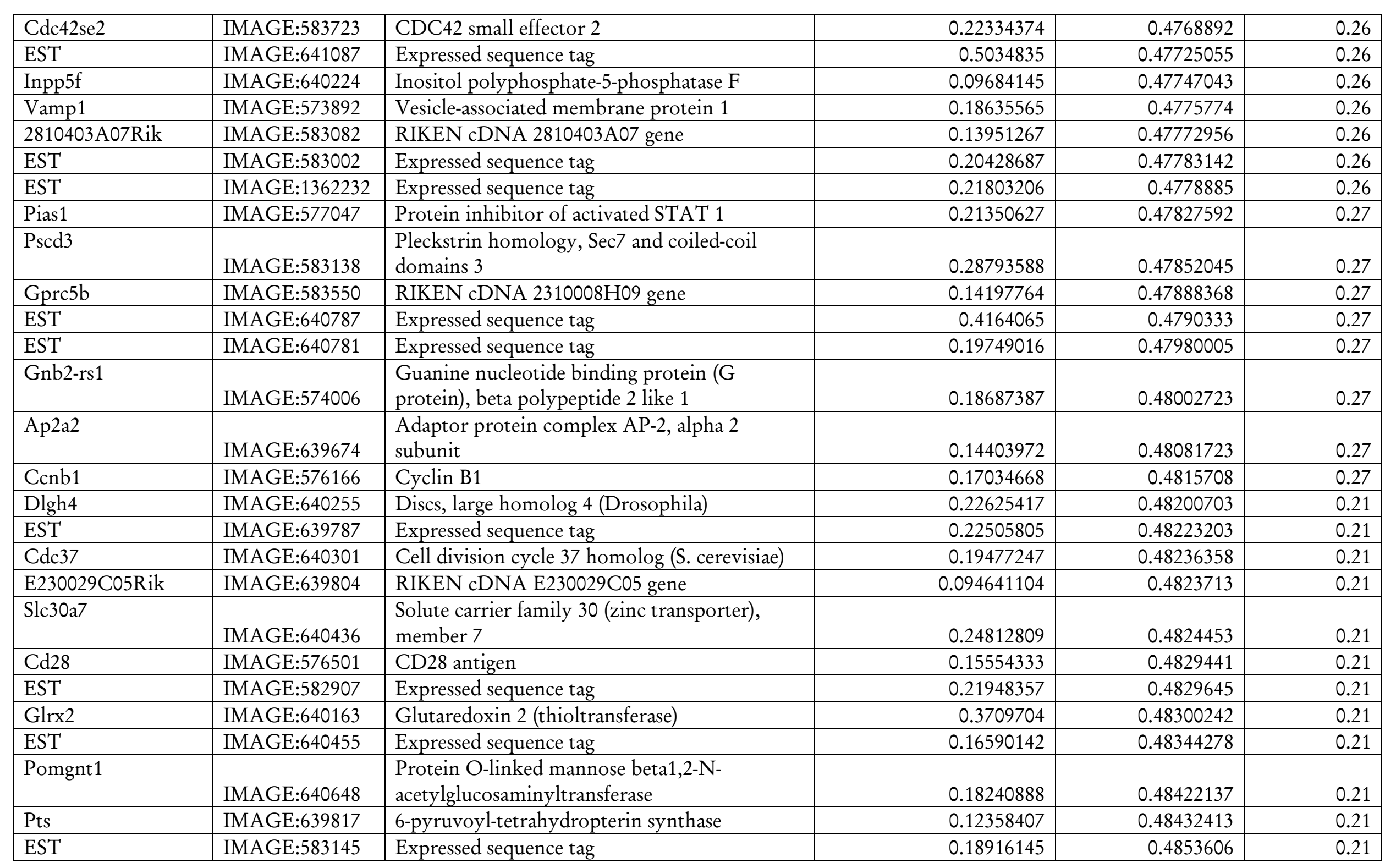




\begin{tabular}{|c|c|c|c|c|c|}
\hline Tfdp1 & IMAGE:640119 & Transcribed locus & 0.164275 & 0.48550537 & 0.21 \\
\hline XRCC4 & IMAGE:2383277 & $\begin{array}{l}\text { X-ray repair complementing defective repair in } \\
\text { Chinese hamster cells } 4\end{array}$ & 0.19961604 & 0.48570868 & 0.22 \\
\hline EST & IMAGE:640909 & Expressed sequence tag & 0.13112594 & 0.48674083 & 0.22 \\
\hline Mtdh & IMAGE:640549 & Metadherin & 0.12898394 & 0.4873163 & 0.22 \\
\hline EST & IMAGE:640416 & Expressed sequence tag & 0.09957807 & 0.48751202 & 0.22 \\
\hline EST & IMAGE: 640370 & Expressed sequence tag & 0.14670296 & 0.48756543 & 0.22 \\
\hline Hrh3 & IMAGE:573677 & Histamine receptor $\mathrm{H} 3$ & 0.17119707 & 0.48873988 & 0.22 \\
\hline Cyb561d2 & IMAGE:640083 & Cytochrome b-561 domain containing 2 & 0.16336505 & 0.4891482 & 0.22 \\
\hline EST & IMAGE:641115 & Expressed sequence tag & 0.16734755 & 0.48946708 & 0.22 \\
\hline Zcchc11 & IMAGE:582979 & Zinc finger, $\mathrm{CCHC}$ domain containing 11 & 0.21965896 & 0.48990157 & 0.22 \\
\hline EST & IMAGE:583097 & Expressed sequence tag & 0.18905367 & 0.49028417 & 0.22 \\
\hline Prp19 & IMAGE:583380 & $\begin{array}{l}\text { PRP19/PSO4 pre-mRNA processing factor } 19 \\
\text { homolog (S. cerevisiae) }\end{array}$ & 0.08591524 & 0.49032435 & 0.22 \\
\hline C1qb & IMAGE:583277 & $\begin{array}{l}\text { Complement component } 1 \text {, q subcomponent, } \\
\text { beta polypeptide }\end{array}$ & 0.18947515 & 0.49202642 & 0.22 \\
\hline EST & IMAGE:583884 & Expressed sequence tag & 0.091222055 & 0.4920771 & 0.22 \\
\hline Aars & IMAGE:640995 & Alanyl-tRNA synthetase & 0.16713159 & 0.4921125 & 0.22 \\
\hline Tagap & IMAGE:639756 & T-cell activation GTPase activating protein 1 & 0.094393566 & 0.49229187 & 0.22 \\
\hline 4930427A07Rik & IMAGE:1225262 & RIKEN cDNA 4930427A07 gene & 0.11545827 & 0.49275184 & 0.22 \\
\hline Btg2 & IMAGE:574837 & B-cell translocation gene 2, anti-proliferative & 0.15162195 & 0.49278197 & 0.22 \\
\hline EST & IMAGE:583630 & Expressed sequence tag & 0.29512927 & 0.493871 & 0.17 \\
\hline Transcribed locus & IMAGE:639995 & & 0.36118522 & 0.4940328 & 0.17 \\
\hline Sox4 & IMAGE:573051 & SRY-box containing gene 4 & 0.112269714 & 0.4944265 & 0.17 \\
\hline Dmtf1 & IMAGE:640217 & RIKEN cDNA E030031F02 gene & 0.19540049 & 0.4944575 & 0.17 \\
\hline
\end{tabular}




\begin{tabular}{|c|c|c|c|c|c|}
\hline Nos2 & IMAGE:4978648 & Nitric oxide synthase 2 , inducible, macrophage & 0.3178935 & 0.49450976 & 0.17 \\
\hline Psmb9 & IMAGE:641076 & $\begin{array}{l}\text { Proteosome (prosome, macropain) subunit, } \\
\text { beta type } 9 \text { (large multifunctional peptidase 2) }\end{array}$ & 0.10554914 & 0.49461052 & 0.17 \\
\hline E2f2 & IMAGE:582911 & E2F transcription factor 2 & 0.33447585 & 0.49500376 & 0.17 \\
\hline Rbm39 & IMAGE:582834 & RNA binding motif protein 39 & 0.20401609 & 0.49532282 & 0.17 \\
\hline EST & IMAGE:640658 & Expressed sequence tag & 0.14834438 & 0.49566662 & 0.17 \\
\hline EST & IMAGE:640388 & Expressed sequence tag & 0.24685533 & 0.49604195 & 0.17 \\
\hline Jak1 & IMAGE:639840 & $\begin{array}{l}\text { CDNA, clone:Y1G0138P08, strand:plus, } \\
\text { reference:ENSEMBL:Mouse-Transcript- } \\
\text { ENST:ENSMUST00000030255, based on } \\
\text { BLAT search }\end{array}$ & 0.1075994 & 0.49799746 & 0.17 \\
\hline Rhoa & IMAGE:572818 & $\begin{array}{l}\text { CDNA, clone:YOG0104B14, strand:minus, } \\
\text { reference:ENSEMBL:Mouse-Transcript- } \\
\text { ENST:ENSMUST00000007959, based on } \\
\text { BLAT search }\end{array}$ & 0.021658225 & 0.49844038 & 0.17 \\
\hline EST & IMAGE:583344 & Expressed sequence tag & 0.08318424 & 0.4996085 & 0.17 \\
\hline EST & IMAGE:583844 & Expressed sequence tag & 0.24229437 & 0.49980402 & 0.17 \\
\hline EST & IMAGE:576500 & Expressed sequence tag & 0.20051917 & 0.49998504 & 0.17 \\
\hline EST & IMAGE:640451 & Expressed sequence tag & 0.38748118 & 0.5006749 & 0.17 \\
\hline Chd9 & IMAGE:639708 & $\begin{array}{l}\text { Chromodomain helicase DNA binding } \\
\text { protein } 9\end{array}$ & 0.094131924 & 0.500939 & 0.17 \\
\hline Birc3 & IMAGE:640942 & Baculoviral IAP repeat-containing 3 & 0.31191644 & 0.50129527 & 0.17 \\
\hline Ly86 & IMAGE:583305 & Lymphocyte antigen 86 & 0.04890407 & 0.5015906 & 0.17 \\
\hline Rasgef1a & IMAGE:640917 & RasGEF domain family, member 1A & 0.27733576 & 0.5016265 & 0.17 \\
\hline Cldnd1 & IMAGE:583307 & Claudin domain containing 1 & 0.33875048 & 0.50193053 & 0.17 \\
\hline EST & IMAGE:583100 & Expressed sequence tag & 0.23808527 & 0.5019472 & 0.17 \\
\hline
\end{tabular}


ANEXO I

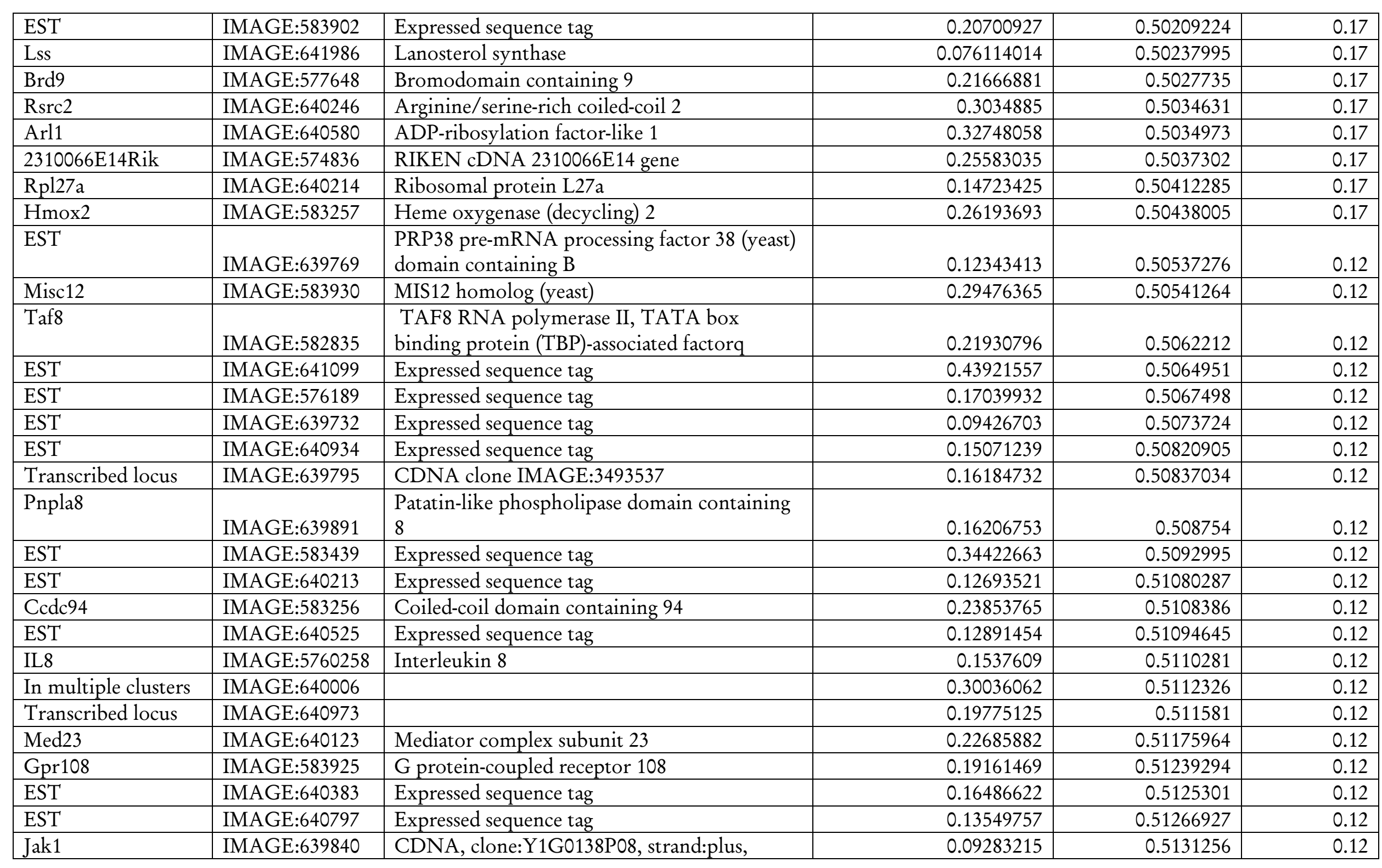




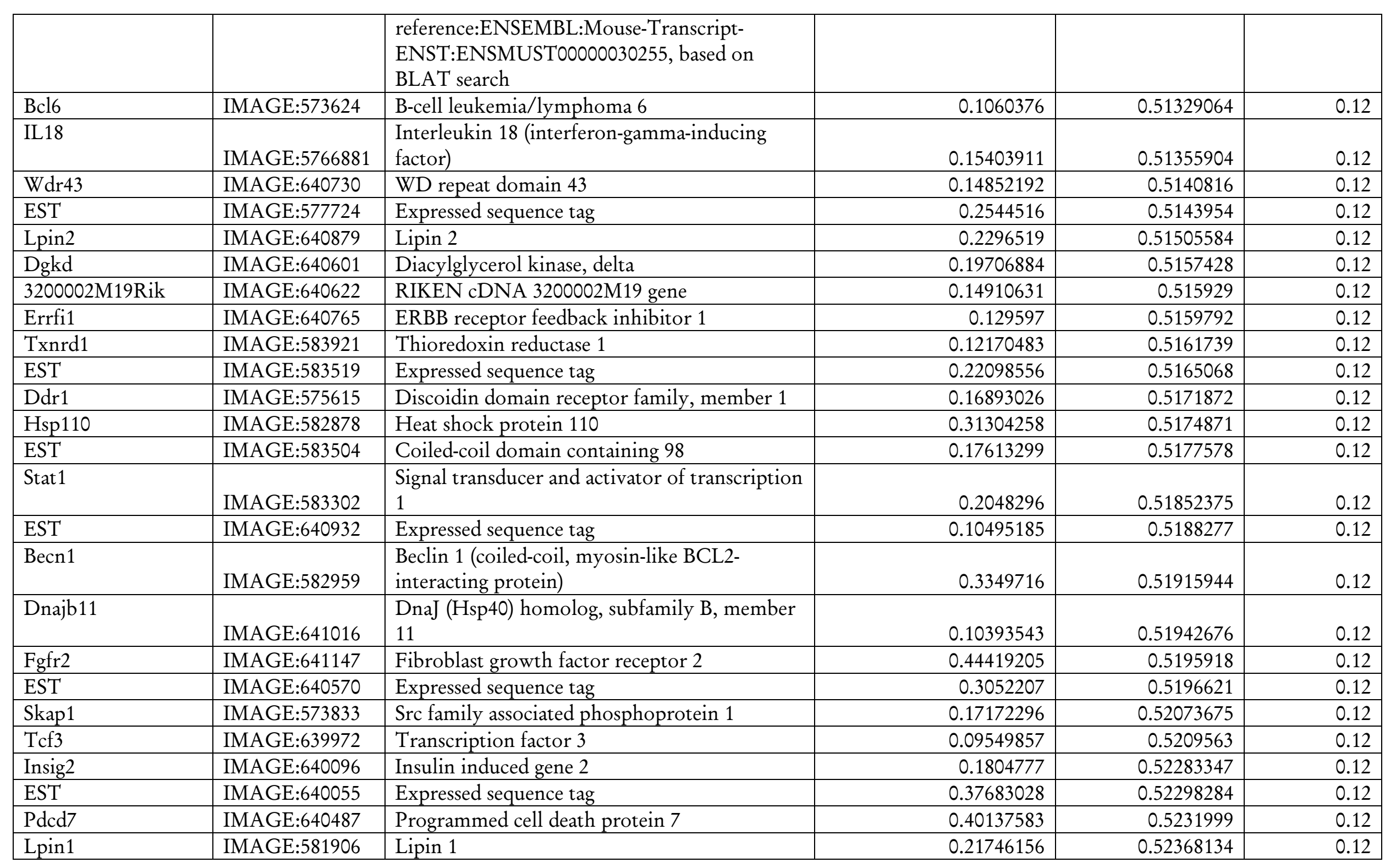


ANEXO I

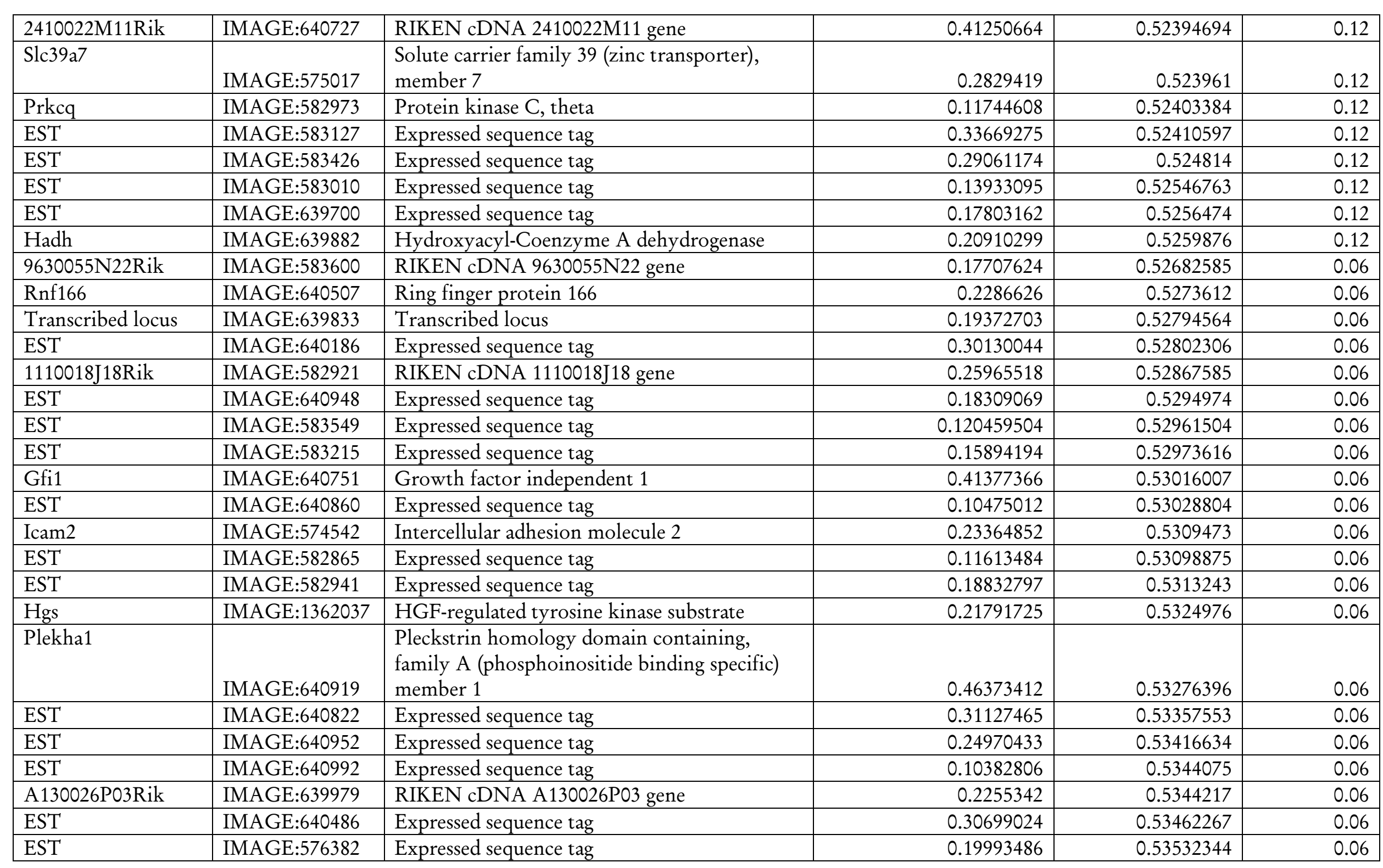




\begin{tabular}{|c|c|c|c|c|c|}
\hline Zmat5 & IMAGE:574272 & Zinc finger, matrin type 5 & 0.21565072 & 0.53540295 & 0.06 \\
\hline Cacnb3 & IMAGE:583865 & $\begin{array}{l}\text { Calcium channel, voltage-dependent, beta } 3 \\
\text { subunit }\end{array}$ & 0.19231188 & 0.5355396 & 0.06 \\
\hline Erh & IMAGE:583664 & $\begin{array}{l}\text { Enhancer of rudimentary homolog } \\
\text { (Drosophila) }\end{array}$ & 0.2407312 & 0.53561157 & 0.06 \\
\hline Pcgf5 & IMAGE:582943 & Polycomb group ring finger 5 & 0.21878202 & 0.5356839 & 0.06 \\
\hline EST & IMAGE:640855 & & 0.22958882 & 0.5357983 & 0.06 \\
\hline Strap & IMAGE:583713 & $\begin{array}{l}\text { Serine/threonine kinase receptor associated } \\
\text { protein }\end{array}$ & 0.26475862 & 0.5367087 & 0.06 \\
\hline Ppp1r9b & IMAGE:640962 & Protein phosphatase 1 , regulatory subunit 9B & 0.2127891 & 0.5371898 & 0.06 \\
\hline Vps36 & IMAGE:640102 & Vacuolar protein sorting 36 (yeast) & 0.30279672 & 0.53748107 & 0.06 \\
\hline EST & IMAGE:639733 & Expressed sequence tag & 0.1244709 & 0.538895 & 0.06 \\
\hline Bag2 & IMAGE:573075 & Bcl2-associated athanogene 2 & 0.112358525 & 0.5394721 & 0.06 \\
\hline EST & IMAGE:583800 & Expressed sequence tag & 0.088619255 & 0.5395805 & 0.06 \\
\hline Tbcel & IMAGE:583526 & Tubulin folding cofactor E-like & 0.14191842 & 0.5398346 & 0.06 \\
\hline Rnf5 & IMAGE:640281 & Ring finger protein 5 & 0.27066663 & 0.5422499 & 0.06 \\
\hline EST & IMAGE:582864 & Expressed sequence AU020206 & 0.076923795 & 0.5423601 & 0.06 \\
\hline D10Bwg1070e & IMAGE:583610 & $\begin{array}{l}\text { DNA segment, Chr 10, Brigham \& Women's } \\
\text { Genetics } 1070 \text { expressed }\end{array}$ & 0.14215766 & 0.5430077 & 0.06 \\
\hline Cope & IMAGE:574058 & Coatomer protein complex, subunit epsilon & 0.13787648 & 0.5434906 & 0.06 \\
\hline EST & IMAGE:640794 & Expressed sequence tag & 0.1353031 & 0.54441935 & 0.06 \\
\hline Clone DB.1 & IMAGE:573388 & Clone DB.1 T cell receptor delta chain & 0.1366657 & 0.54525334 & 0.06 \\
\hline Pctk1 & IMAGE:640693 & PCTAIRE-motif protein kinase 1 & 0.12938836 & 0.54581887 & 0.06 \\
\hline EST & IMAGE:639736 & Expressed sequence tag & 0.17886813 & 0.54591256 & 0.06 \\
\hline EST & IMAGE:583528 & Expressed sequence tag & 0.17618664 & 0.546018 & 0.06 \\
\hline Wdsub1 & IMAGE:640769 & WD repeat, SAM and U-box domain & 0.19743752 & 0.5460643 & 0.06 \\
\hline
\end{tabular}




\begin{tabular}{|c|c|c|c|c|c|}
\hline & & containing 1 & & & \\
\hline Kif14 & IMAGE:583647 & Kinesin family member 14 & 0.16075969 & 0.5461313 & 0.06 \\
\hline EST & IMAGE:640861 & Expressed sequence tag & 0.13098764 & 0.5467287 & 0.06 \\
\hline EST & IMAGE:583050 & Expressed sequence tag & 0.20433937 & 0.5469681 & 0.06 \\
\hline EST & IMAGE:639775 & Expressed sequence tag & 0.22411872 & 0.5470471 & 0.06 \\
\hline Gga1 & IMAGE:640935 & $\begin{array}{l}\text { Golgi associated, gamma adaptin ear } \\
\text { containing, ARF binding protein } 1\end{array}$ & 0.16776794 & 0.54727286 & 0.06 \\
\hline EST & IMAGE:575820 & Expressed sequence tag & 0.15308909 & 0.54812384 & 0.06 \\
\hline EST & IMAGE:640231 & Expressed sequence tag & 0.22619554 & 0.5483948 & 0.06 \\
\hline EST & IMAGE:640794 & Expressed sequence tag & 0.21251145 & 0.5491544 & 0.07 \\
\hline EST & IMAGE:640309 & Expressed sequence tag & 0.12721592 & 0.5491956 & 0.07 \\
\hline EST & IMAGE:583007 & Expressed sequence tag & 0.33545718 & 0.5496869 & 0.07 \\
\hline Dgkd & IMAGE:583692 & Diacylglycerol kinase, delta & 0.090142116 & 0.54977095 & 0.07 \\
\hline Acat2 & IMAGE:583609 & Acetyl-Coenzyme A acetyltransferase 2 & 0.12070159 & 0.5504583 & 0.07 \\
\hline Zcchc7 & IMAGE:575396 & Zinc finger, CCHC domain containing 7 & 0.13400303 & 0.5505079 & 0.07 \\
\hline 4930523C07Rik & IMAGE:583877 & RIKEN cDNA 4930523C07 gene & 0.1915109 & 0.55073535 & 0.07 \\
\hline EST & IMAGE:640816 & & 0.18351197 & 0.55085975 & 0.07 \\
\hline Map2k1ip1 & IMAGE:575958 & $\begin{array}{l}\text { Mitogen-activated protein kinase kinase } 1 \\
\text { interacting protein } 1\end{array}$ & 0.11349201 & 0.5510415 & 0.07 \\
\hline Cebpg & IMAGE:640947 & $\begin{array}{l}\text { CCAAT/enhancer binding protein (C/EBP), } \\
\text { gamma }\end{array}$ & 0.1670212 & 0.5510602 & 0.07 \\
\hline Bnip2 & IMAGE:640945 & $\begin{array}{l}\text { BCL2/adenovirus E1B interacting protein 1, } \\
\text { NIP2 }\end{array}$ & 0.13014787 & 0.5517748 & 0.07 \\
\hline EST & IMAGE:640922 & Expressed sequence tag & 0.14985436 & 0.5521537 & 0.07 \\
\hline
\end{tabular}


ANEXO I

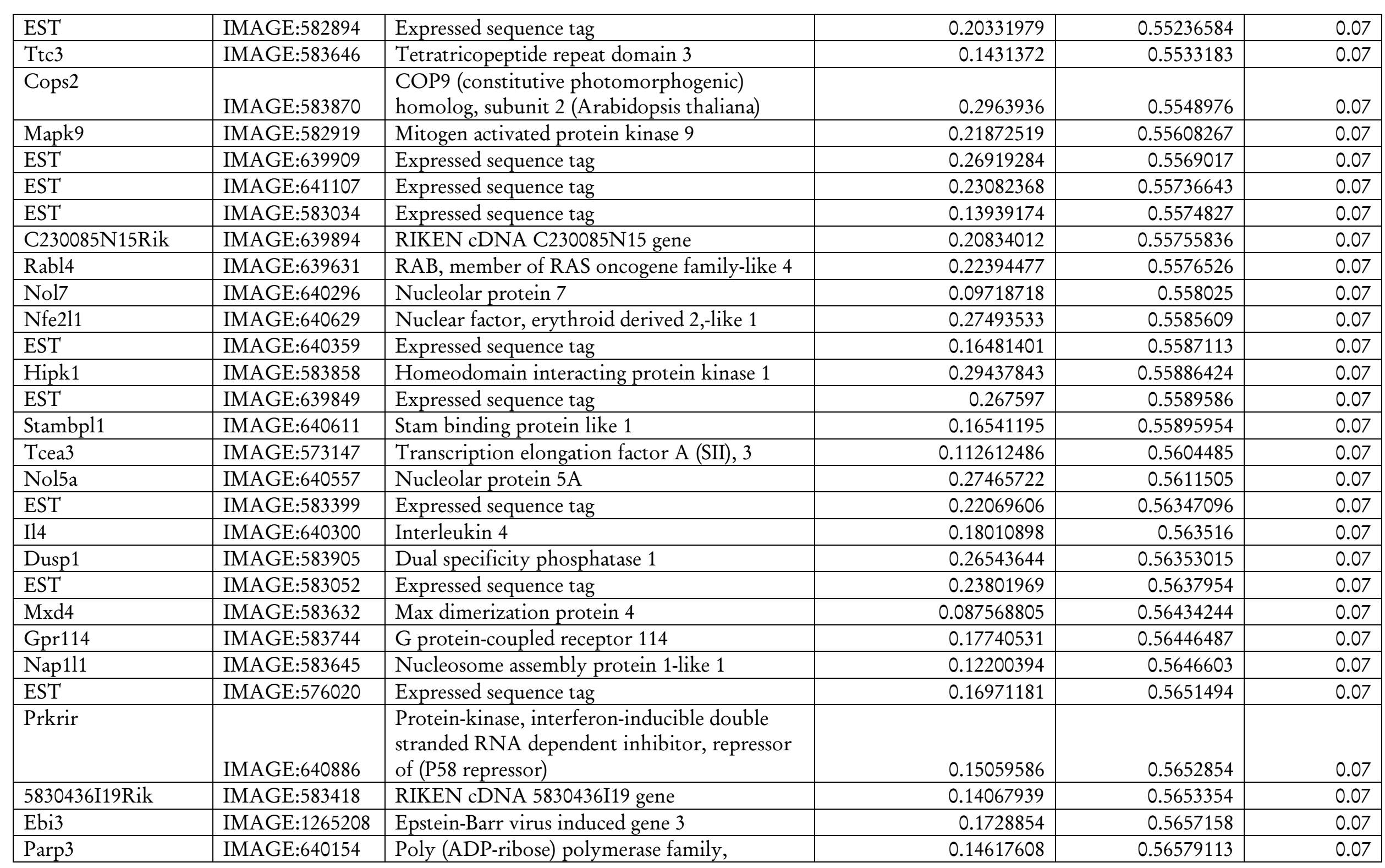




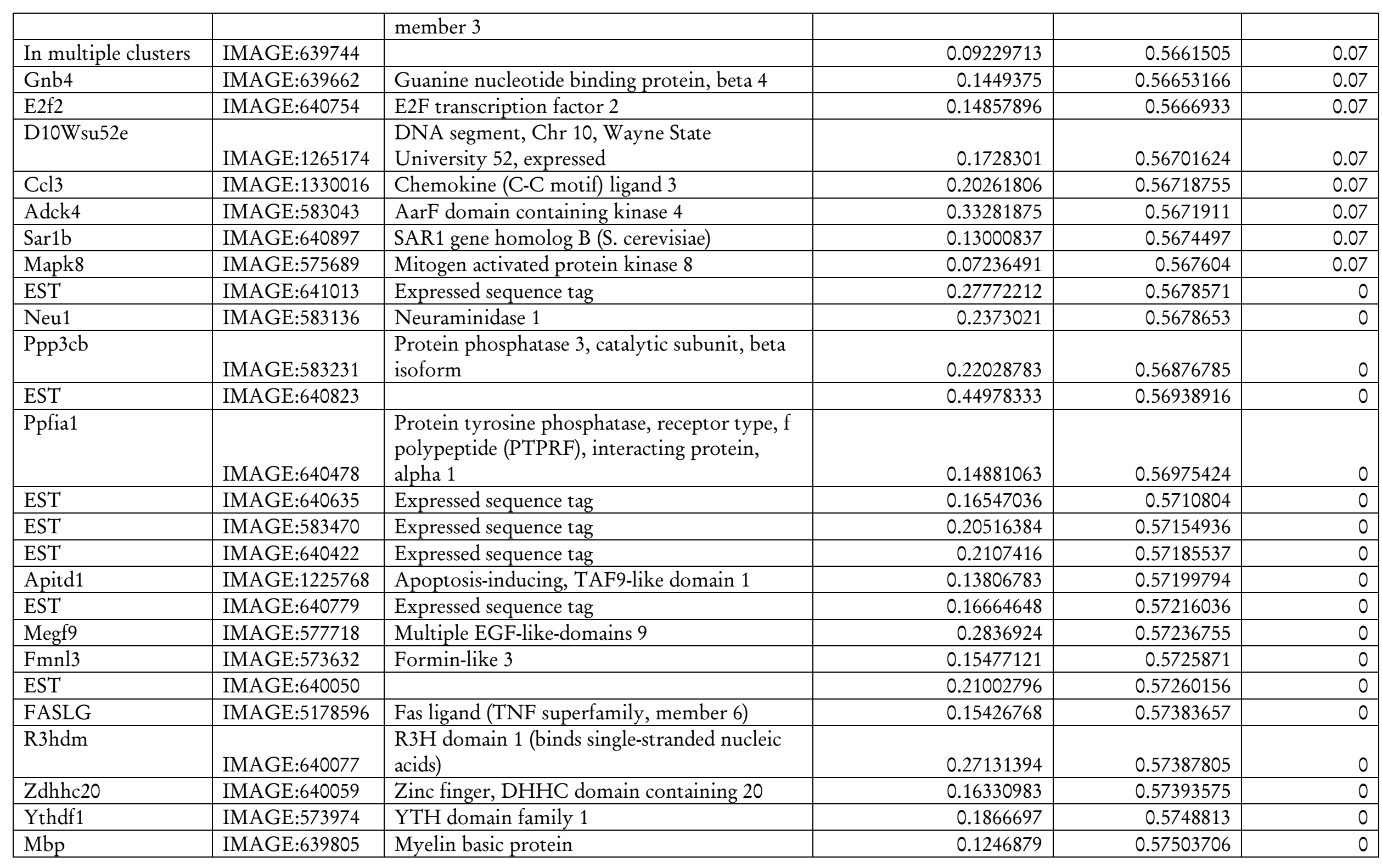




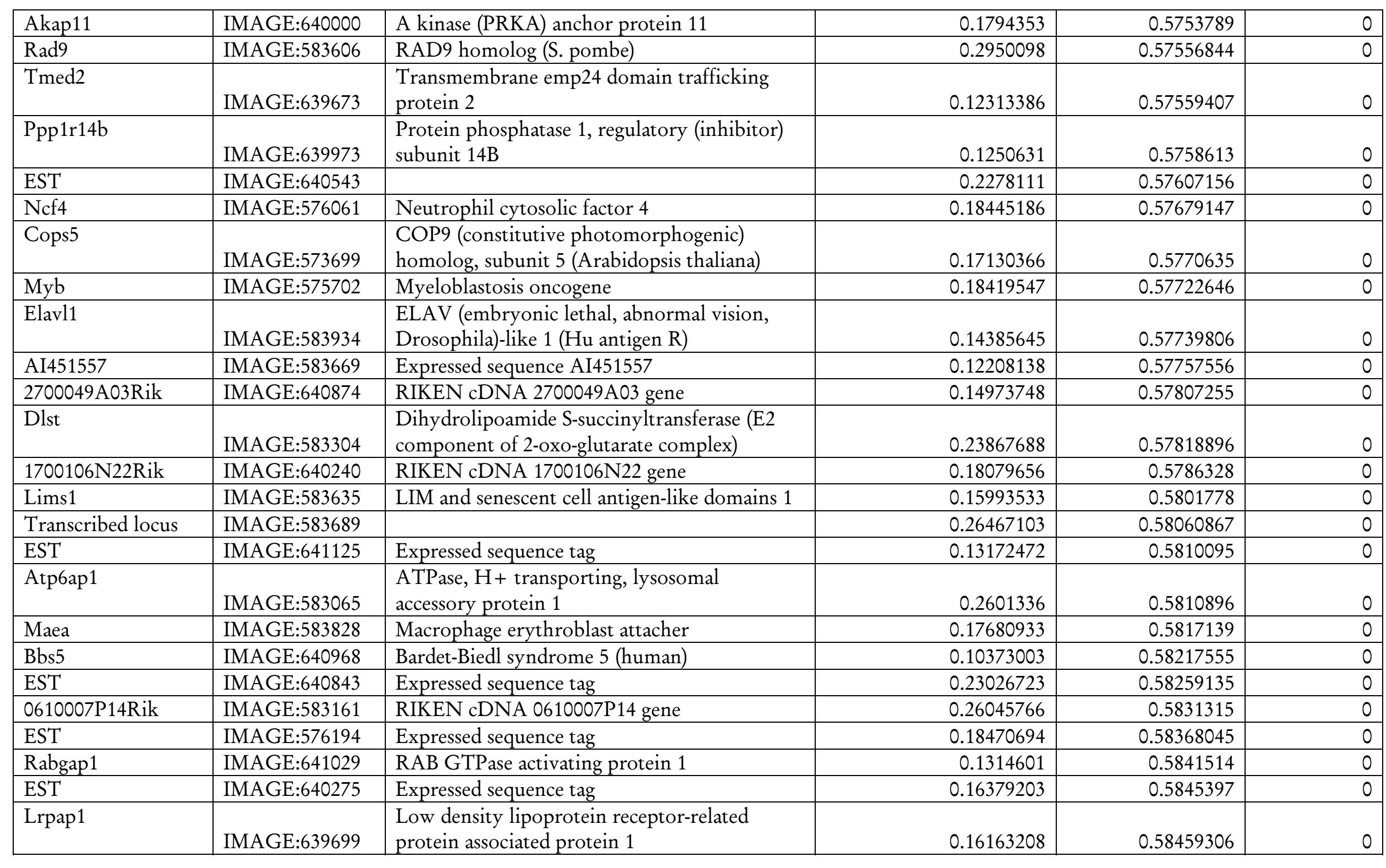




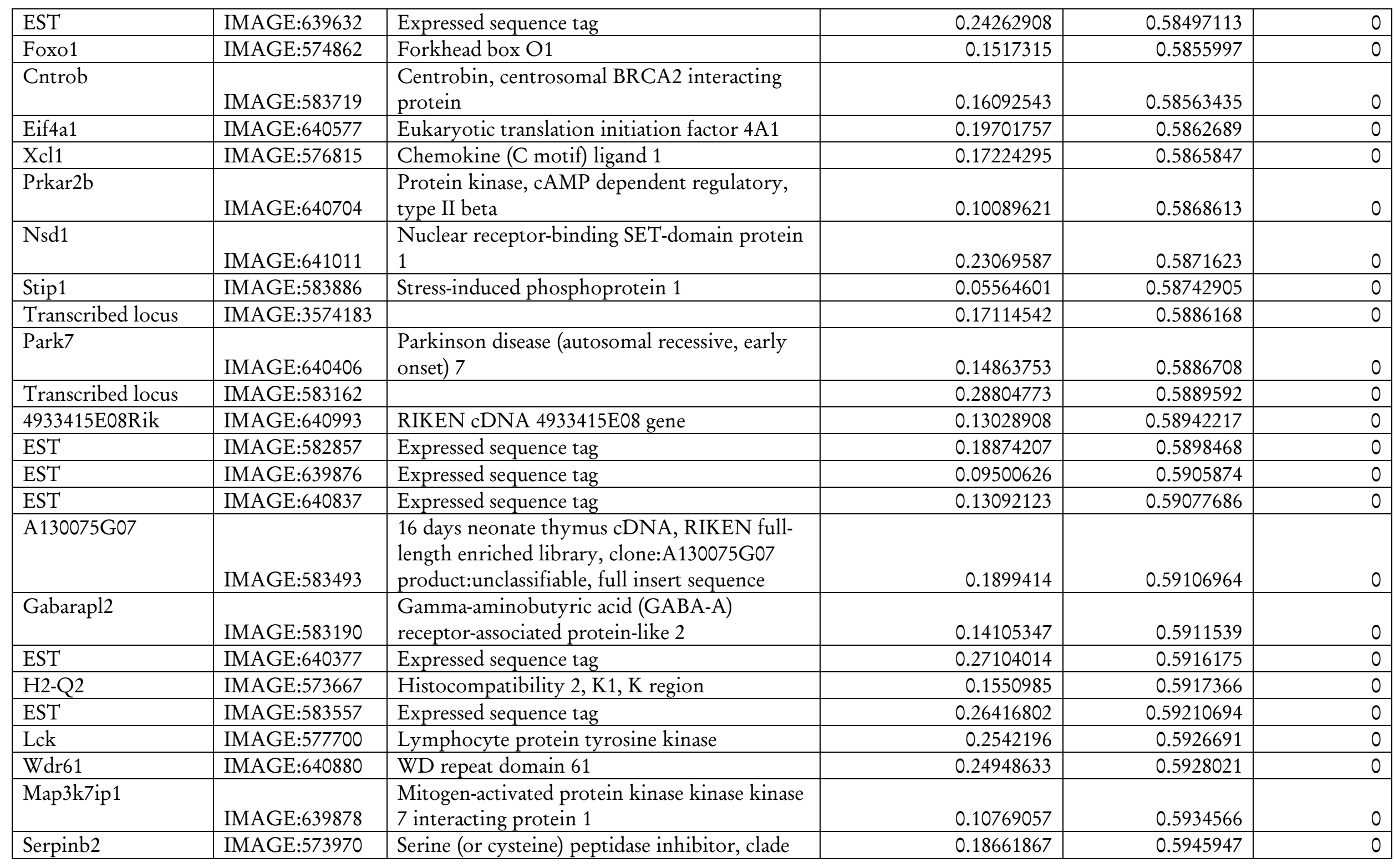




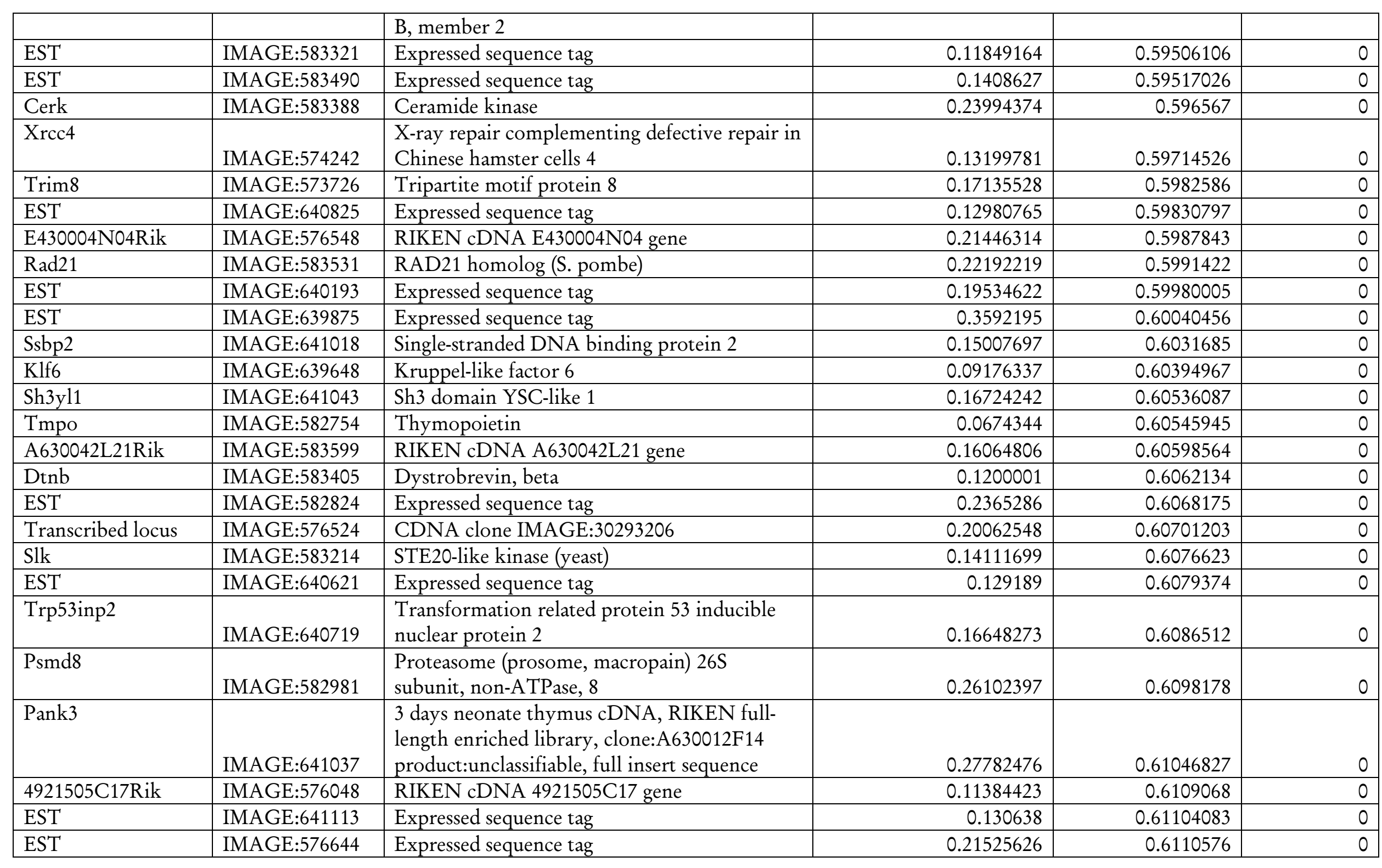




\begin{tabular}{|c|c|c|c|c|c|}
\hline Ankrd10 & IMAGE:583740 & Ankyrin repeat domain 10 & 0.09041374 & 0.6112935 & 0 \\
\hline EST & IMAGE:640351 & Expressed sequence tag & 0.22649825 & 0.6113829 & 0 \\
\hline EST & IMAGE:640105 & & 0.12549669 & 0.6118786 & 0 \\
\hline EST & IMAGE:640027 & Expressed sequence tag & 0.22661947 & 0.6140328 & 0 \\
\hline Lef1 & IMAGE:575374 & Lymphoid enhancer binding factor 1 & 0.1101145 & 0.6141012 & 0 \\
\hline 2810442I21Rik & IMAGE:1226803 & RIKEN cDNA 2810442I21 gene & 0.13863099 & 0.61464864 & 0 \\
\hline EST & IMAGE:583529 & Expressed sequence tag & 0.19082807 & 0.615881 & 0 \\
\hline 5730508B09Rik & IMAGE:639881 & RIKEN cDNA 5730508B09 gene & 0.19383171 & 0.61591375 & 0 \\
\hline EST & IMAGE:640341 & Expressed sequence tag & 0.27233028 & 0.61604214 & 0 \\
\hline Tmie & IMAGE:640505 & Transmembrane inner ear & 0.19686215 & 0.6163534 & 0 \\
\hline Prkag1 & IMAGE:640537 & $\begin{array}{l}\text { Protein kinase, AMP-activated, gamma } 1 \text { non- } \\
\text { catalytic subunit }\end{array}$ & 0.12792921 & 0.616834 & 0 \\
\hline Got1 & IMAGE: 640640 & Glutamate oxaloacetate transaminase 1 , soluble & 0.24763133 & 0.6174141 & 0 \\
\hline Suv39h1 & IMAGE:640238 & $\begin{array}{l}\text { Suppressor of variegation 3-9 homolog } 1 \\
\text { (Drosophila) }\end{array}$ & 0.1472913 & 0.61868167 & 0 \\
\hline Srpk2 & IMAGE:640659 & Serine/arginine-rich protein specific kinase 2 & 0.16552153 & 0.61934835 & 0 \\
\hline 5930434B04Rik & IMAGE:583644 & RIKEN cDNA 5930434B04 gene & 0.08988068 & 0.6212908 & 0 \\
\hline Selenoprotein 15 & IMAGE:582910 & Selenoprotein & 0.2886248 & 0.62209004 & 0 \\
\hline TNF & IMAGE:5213134 & $\begin{array}{l}\text { Tumor necrosis factor (TNF superfamily, } \\
\text { member 2) }\end{array}$ & 0.17071606 & 0.622866 & 0 \\
\hline Fancc & IMAGE:582993 & Fanconi anemia, complementation group C & 0.25989532 & 0.6244712 & 0 \\
\hline Tusc4 & IMAGE:640378 & Tumor suppressor candidate 4 & 0.3023817 & 0.62480545 & 0 \\
\hline Xpot & IMAGE:639640 & $\begin{array}{l}\text { Exportin, tRNA (nuclear export receptor for } \\
\text { tRNAs) }\end{array}$ & 0.17870922 & 0.62504584 & 0 \\
\hline Rbm22 & IMAGE:583263 & RNA binding motif protein 22 & 0.15905473 & 0.62546045 & 0 \\
\hline Sox 4 & IMAGE:640239 & SRY-box containing gene 4 & 0.16454339 & 0.6260612 & 0 \\
\hline
\end{tabular}




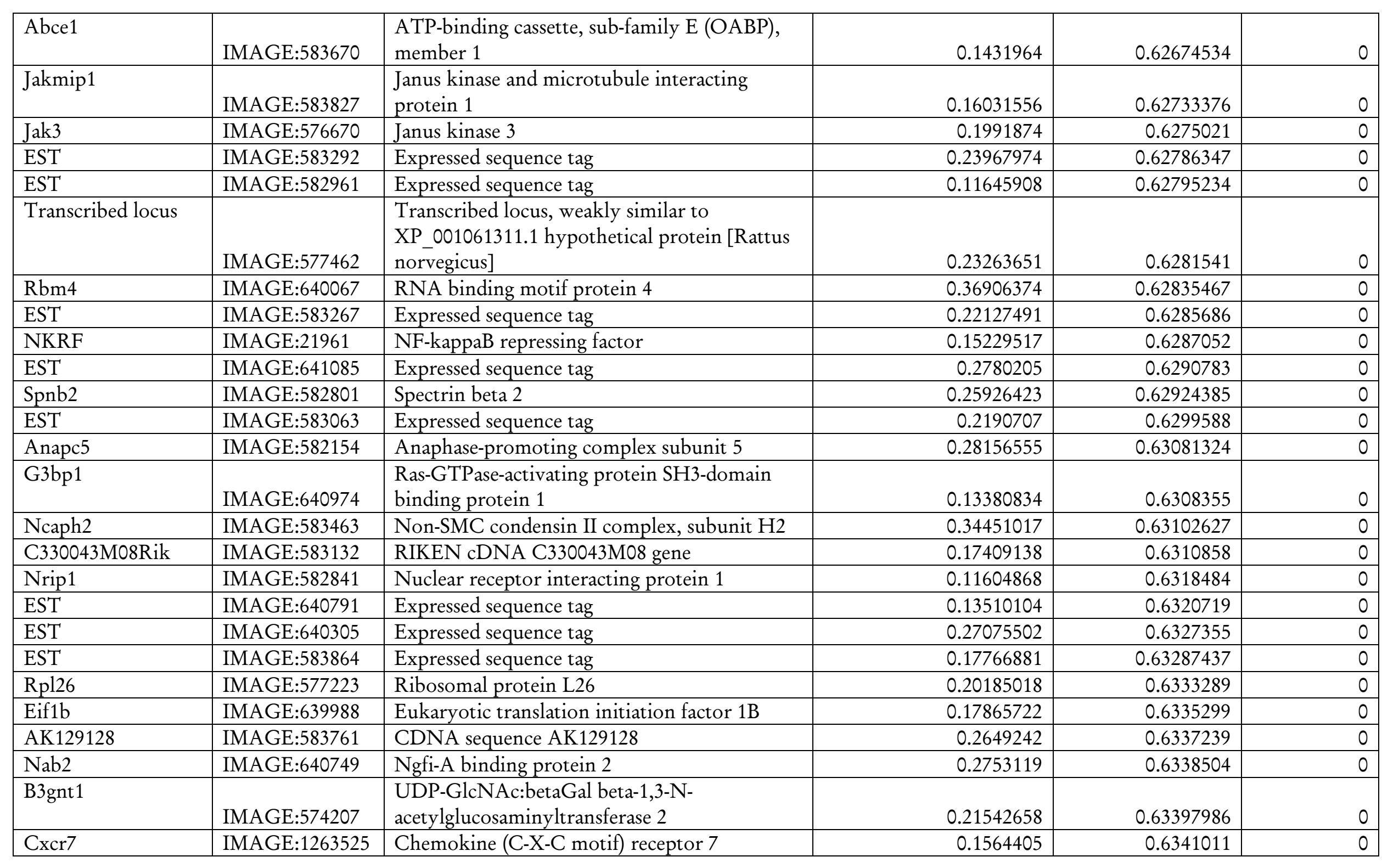




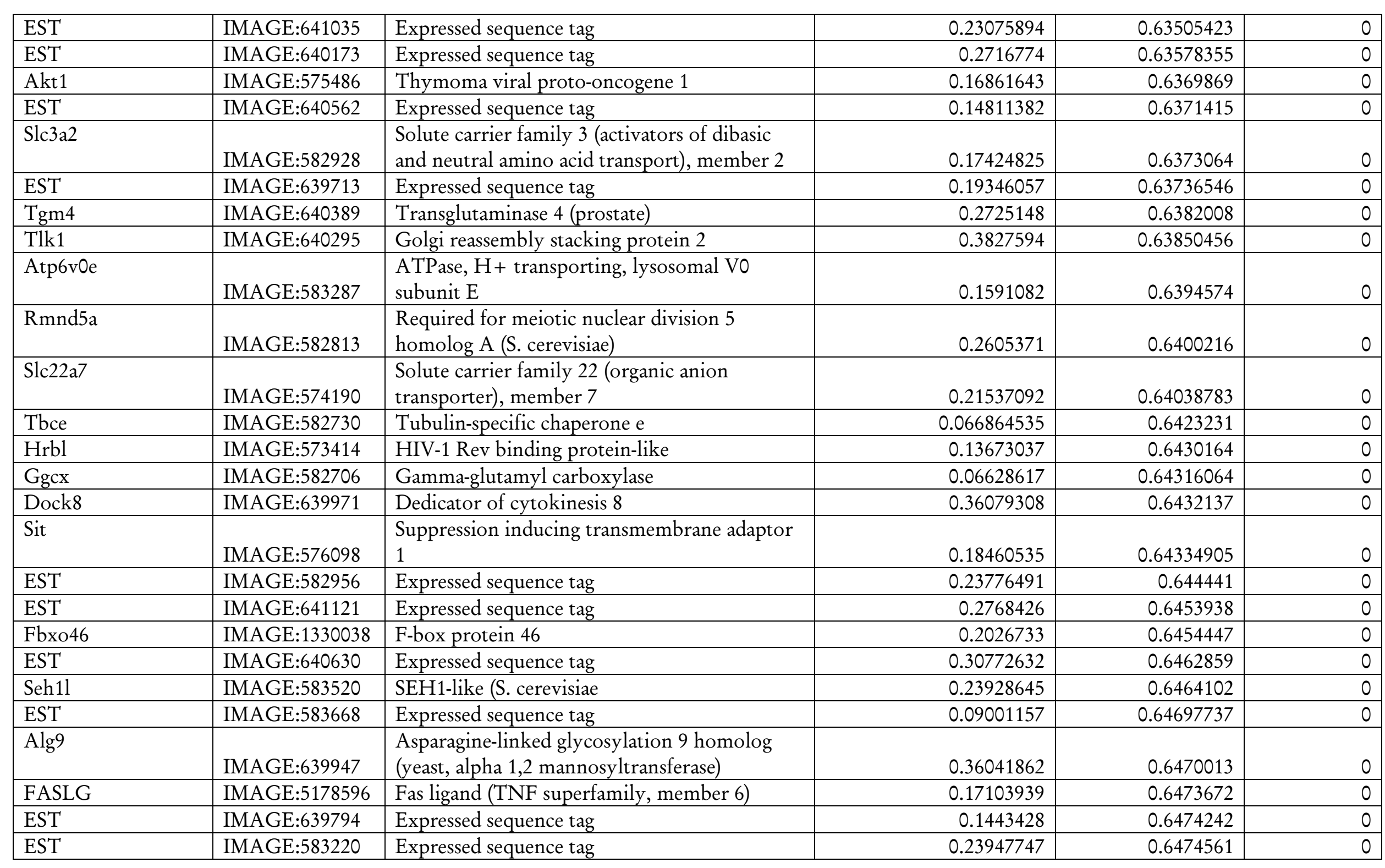




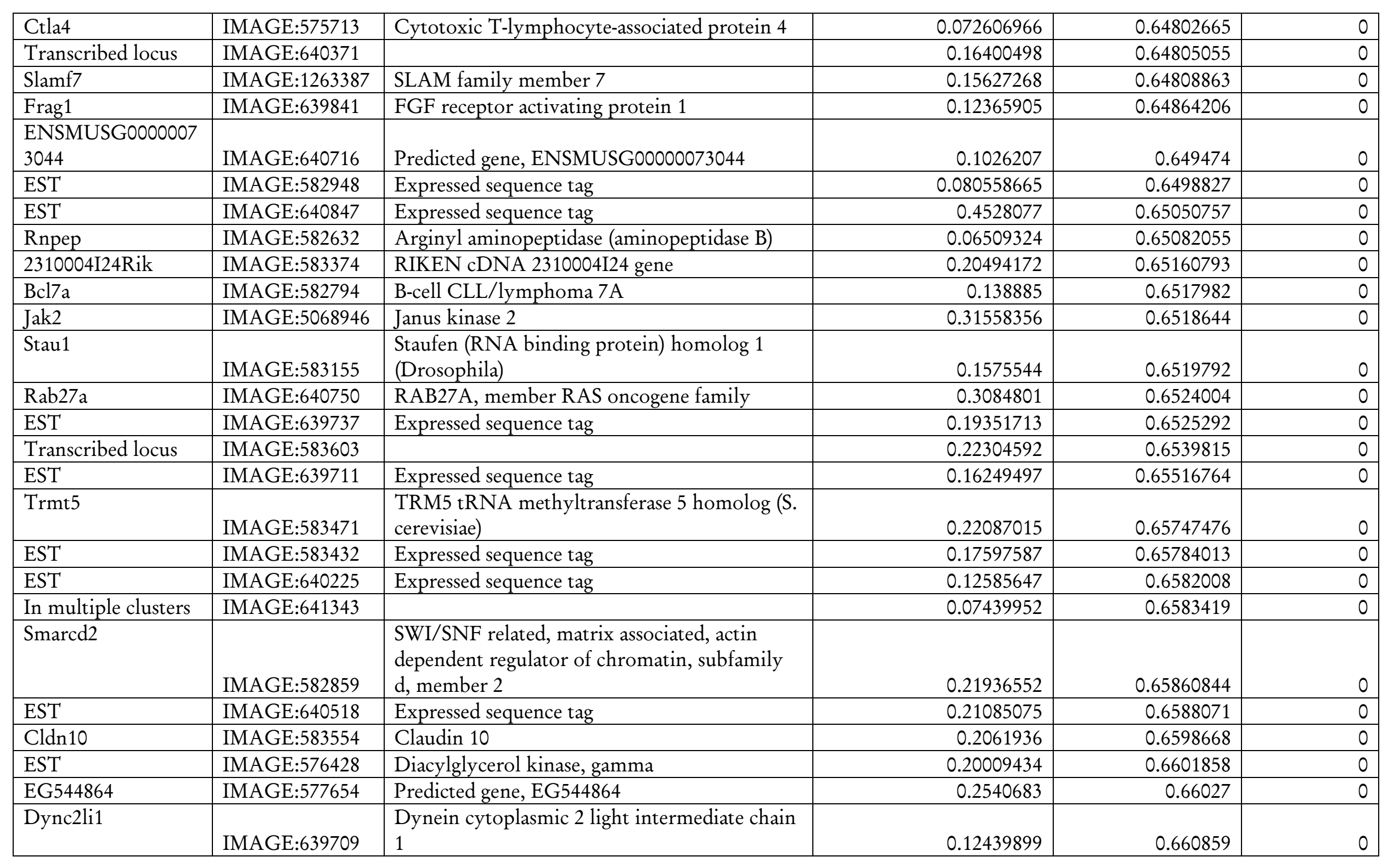




\begin{tabular}{|c|c|c|c|c|c|}
\hline Vcam1 & IMAGE:576563 & Vascular cell adhesion molecule 1 & 0.21457873 & 0.6613954 & 0 \\
\hline EST & IMAGE:640656 & Expressed sequence tag & 0.10067886 & 0.6622571 & 0 \\
\hline Ptgs1 & IMAGE:5041952 & Prostaglandin-endoperoxide synthase 1 & 0.28086063 & 0.6636433 & 0 \\
\hline Rap2a & IMAGE:583613 & RAS related protein $2 \mathrm{a}$ & 0.1909839 & 0.6652152 & 0 \\
\hline Irf8 & IMAGE:640774 & Interferon regulatory factor 8 & 0.30863506 & 0.6663607 & 0 \\
\hline Nfkb1 & IMAGE:575033 & $\begin{array}{l}\text { Nuclear factor of kappa light chain gene } \\
\text { enhancer in B-cells 1, p105 }\end{array}$ & 0.28305134 & 0.66741085 & 0 \\
\hline EST & IMAGE:640015 & Expressed sequence tag & 0.22565359 & 0.66812897 & 0 \\
\hline 2900076A07Rik & IMAGE:583769 & RIKEN cDNA 2900076A07 gene & 0.19209681 & 0.6698119 & 0 \\
\hline Sh3glb1 & IMAGE:577165 & SH3-domain GRB2-like B1 (endophilin) & 0.21373369 & 0.67040926 & 0 \\
\hline EST & IMAGE:583516 & Expressed sequence tag & 0.17535445 & 0.6709999 & 0 \\
\hline Pdha1 & IMAGE:583233 & Pyruvate dehydrogenase E1 alpha 1 & 0.26185915 & 0.6717668 & 0 \\
\hline Flt3 & IMAGE:576267 & FMS-like tyrosine kinase 3 & 0.13730833 & 0.6721882 & 0 \\
\hline Asxl2 & IMAGE:1281412 & Additional sex combs like 2 (Drosophila) & 0.1732522 & 0.67330325 & 0 \\
\hline EST & IMAGE:640417 & Expressed sequence tag & 0.12757416 & 0.673491 & 0 \\
\hline Tollip & IMAGE:4951445 & Toll interacting protein & 0.317535 & 0.6737925 & 0 \\
\hline Psma5 & IMAGE:639989 & $\begin{array}{l}\text { Proteasome (prosome, macropain) subunit, } \\
\text { alpha type } 5\end{array}$ & 0.19325256 & 0.6740738 & 0 \\
\hline EST & IMAGE:639763 & Expressed sequence tag & 0.22499973 & 0.6743433 & 0 \\
\hline $\mathrm{C} 130036 \mathrm{~K} 02$ & IMAGE:583575 & Transcribed locus & 0.16059211 & 0.6743841 & 0 \\
\hline Slc3a2 & IMAGE:583139 & $\begin{array}{l}\text { Solute carrier family } 3 \text { (activators of dibasic } \\
\text { and neutral amino acid transport), member } 2\end{array}$ & 0.33351967 & 0.67508745 & 0 \\
\hline AI481772 & IMAGE:583909 & Expressed sequence AI481772 & 0.25776374 & 0.67527413 & 0 \\
\hline Mthfr & IMAGE:640110 & 5,10-methylenetetrahydrofolate reductase & 0.20943232 & 0.67529535 & 0 \\
\hline
\end{tabular}




\begin{tabular}{|c|c|c|c|c|c|}
\hline EST & IMAGE:640956 & Expressed sequence tag & 0.1050524 & 0.6754842 & 0 \\
\hline EST & IMAGE:640839 & Expressed sequence tag & 0.16755901 & 0.6756553 & 0 \\
\hline Obfc2a & IMAGE:582845 & $\begin{array}{l}\text { Oligonucleotide/oligosaccharide-binding fold } \\
\text { containing 2A }\end{array}$ & 0.18811317 & 0.67758733 & 0 \\
\hline Snapc3 & IMAGE:583409 & $\begin{array}{l}\text { Small nuclear RNA activating complex, } \\
\text { polypeptide } 3\end{array}$ & 0.19056232 & 0.6776366 & 0 \\
\hline EST & IMAGE:640391 & Expressed sequence tag & 0.38533962 & 0.67856294 & 0 \\
\hline Dusp2 & IMAGE:640913 & Dual specificity phosphatase 2 & 0.1983864 & 0.6785886 & 0 \\
\hline Transcribed locus & IMAGE:641142 & Transcribed locus & 0.21245591 & 0.6792396 & 0 \\
\hline 3110037I16Rik & IMAGE:640889 & RIKEN cDNA 3110037I16 gene & 0.19833039 & 0.6795188 & 0 \\
\hline EST & IMAGE:583288 & Expressed sequence tag & 0.17566766 & 0.68066347 & 0 \\
\hline EST & IMAGE:640666 & Expressed sequence tag & 0.30580163 & 0.6809548 & 0 \\
\hline D4Wsu53e & IMAGE:583358 & $\begin{array}{l}\text { DNA segment, Chr 4, Wayne State University } \\
53 \text {, expressed }\end{array}$ & 0.14148726 & 0.6811138 & 0 \\
\hline Cct6a & IMAGE:582061 & Chaperonin subunit 6a (zeta) & 0.2175738 & 0.68172115 & 0 \\
\hline EST & IMAGE:583310 & Expressed sequence tag & 0.14136209 & 0.6840975 & 0 \\
\hline 1600020E01Rik & IMAGE:640044 & RIKEN cDNA 1600020E01 gene & 0.097787276 & 0.6842015 & 0 \\
\hline Gpatc2 & IMAGE:639834 & G patch domain containing 2 & 0.20904918 & 0.68440264 & 0 \\
\hline EST & IMAGE:641090 & Expressed sequence tag & 0.1501903 & 0.68510705 & 0 \\
\hline EST & IMAGE:639969 & Expressed sequence tag & 0.2680322 & 0.68578446 & 0 \\
\hline Uqcrq & IMAGE:640529 & $\begin{array}{l}\text { Ubiquinol-cytochrome c reductase, complex } \\
\text { III subunit VII }\end{array}$ & 0.1969121 & 0.68606955 & 0 \\
\hline Fbxl11 & IMAGE:639916 & F-box and leucine-rich repeat protein 11 & 0.17850156 & 0.68700635 & 0 \\
\hline Yeats4 & IMAGE:582836 & YEATS domain containing 4 & 0.23749758 & 0.6873498 & 0 \\
\hline Cd97 & IMAGE:641135 & CD97 antigen & 0.536733 & 0.68741673 & 0 \\
\hline Tulp3 & IMAGE:583226 & Tubby-like protein 3 & 0.14019334 & 0.687433 & 0 \\
\hline
\end{tabular}




\begin{tabular}{|c|c|c|c|c|c|}
\hline Tegt & IMAGE:639877 & Testis enhanced gene transcript & 0.124761075 & 0.6875081 & 0 \\
\hline Fancc & IMAGE:583016 & Fanconi anemia, complementation group C & 0.23704857 & 0.6888247 & 0 \\
\hline Cops3 & IMAGE:583648 & $\begin{array}{l}\text { COP9 (constitutive photomorphogenic) } \\
\text { homolog, subunit } 3 \text { (Arabidopsis thaliana) }\end{array}$ & 0.17718685 & 0.68978983 & 0 \\
\hline EST & IMAGE:641100 & Expressed sequence tag & 0.10564747 & 0.6903736 & 0 \\
\hline Psip1 & IMAGE:583537 & PC4 and SFRS1 interacting protein 1 & 0.119220965 & 0.6920932 & 0 \\
\hline Il18rap & IMAGE:640615 & Interleukin 18 receptor accessory protein & 0.227993 & 0.69217515 & 0 \\
\hline Ccdc41 & IMAGE:639871 & Coiled-coil domain containing 41 & 0.22435208 & 0.69284207 & 0 \\
\hline Hs3st3b1 & IMAGE:640008 & $\begin{array}{l}\text { Heparan sulfate (glucosamine) 3-O- } \\
\text { sulfotransferase 3B1 }\end{array}$ & 0.09574361 & 0.6930942 & 0 \\
\hline EST & IMAGE:639724 & Expressed sequence tag & 0.17808397 & 0.6942962 & 0 \\
\hline EST & IMAGE:583598 & Expressed sequence tag & 0.143015 & 0.6944292 & 0 \\
\hline Xpot & IMAGE:639806 & $\begin{array}{l}\text { Exportin, tRNA (nuclear export receptor for } \\
\text { tRNAs) }\end{array}$ & 0.14529587 & 0.69512993 & 0 \\
\hline EST & IMAGE:583051 & Expressed sequence tag & 0.21982904 & 0.6955135 & 0 \\
\hline EST & IMAGE:583788 & Expressed sequence tag & 0.09068557 & 0.69597137 & 0 \\
\hline Cybb & IMAGE:583187 & Cytochrome b-245, beta polypeptide & 0.31505698 & 0.69895315 & 0 \\
\hline Hltf & IMAGE:640694 & Helicase-like transcription factor & 0.14927734 & 0.69905347 & 0 \\
\hline Cd164 & IMAGE:640054 & CD164 antigen & 0.30266228 & 0.6998011 & 0 \\
\hline Ndufa11 & IMAGE:640357 & $\begin{array}{l}\text { NADH dehydrogenase (ubiquinone) } 1 \text { alpha } \\
\text { subcomplex } 11\end{array}$ & 0.12735748 & 0.7014962 & 0 \\
\hline Zzz3 & IMAGE:583815 & Zinc finger, $\mathrm{ZZ}$ domain containing 3 & 0.16114314 & 0.702413 & 0 \\
\hline Anxa1 & IMAGE:640741 & Annexin A1 & 0.12952639 & 0.70246565 & 0 \\
\hline EST & IMAGE:640588 & Expressed sequence tag & 0.18157241 & 0.70268375 & 0 \\
\hline EST & IMAGE:640782 & Expressed sequence tag & 0.11102761 & 0.7033643 & 0 \\
\hline EST & IMAGE:582849 & Expressed sequence tag & 0.25942096 & 0.705071 & 0 \\
\hline $\mathrm{Cd} 4$ & IMAGE:640273 & CD4 antigen & 0.12600295 & 0.70600426 & 0 \\
\hline
\end{tabular}




\begin{tabular}{|c|c|c|c|c|c|}
\hline Pcbp1 & IMAGE:640145 & Poly $(\mathrm{rC})$ binding protein 1 & 0.1952406 & 0.70607436 & 0 \\
\hline $\mathrm{B} 2 \mathrm{~m}$ & IMAGE:576472 & Beta-2 microglobulin & 0.20036045 & 0.7065583 & 0 \\
\hline EST & IMAGE:583193 & Expressed sequence tag & 0.1901005 & 0.7103242 & 0 \\
\hline Wdr12 & IMAGE:640744 & WD repeat domain 12 & 0.18261509 & 0.71045685 & 0 \\
\hline Col27a1 & IMAGE:1378843 & Procollagen, type XXVII, alpha 1 & 0.23594911 & 0.7116088 & 0 \\
\hline C130022K22Rik & IMAGE:583889 & RIKEN cDNA C130022K22 gene & 0.19236284 & 0.71382004 & 0 \\
\hline Nol7 & IMAGE:641133 & Nucleolar protein 7 & 0.27821597 & 0.71395254 & 0 \\
\hline Elp4 & IMAGE:583768 & Elongation protein 4 homolog (S. cerevisiae) & 0.17745937 & 0.7140481 & 0 \\
\hline Msn & IMAGE:583860 & Moesin & 0.09109095 & 0.7153999 & 0 \\
\hline Socs1 & IMAGE:583890 & Suppressor of cytokine signaling 1 & 0.20773016 & 0.71598846 & 0 \\
\hline Rpl24 & IMAGE:641145 & Ribosomal protein L24 & 0.2769403 & 0.7171816 & 0 \\
\hline 2610207I05Rik & IMAGE:640606 & RIKEN cDNA 2610207I05 gene & 0.3075754 & 0.7184207 & 0 \\
\hline Atf4 & IMAGE:583297 & Activating transcription factor 4 & 0.118415415 & 0.7193015 & 0 \\
\hline Cep78 & IMAGE: 641590 & Centrosomal protein 78 & 0.07483943 & 0.719304 & 0 \\
\hline Rpl27a & IMAGE:640775 & Ribosomal protein L27a & 0.41503644 & 0.7194412 & 0 \\
\hline EST & IMAGE:583874 & Expressed sequence tag & 0.14276372 & 0.72275186 & 0 \\
\hline Adfp & IMAGE:640464 & Adipose differentiation related protein & 0.09979873 & 0.7235365 & 0 \\
\hline Zfp35 & IMAGE:641159 & Zinc finger protein 35 & 0.580739 & 0.7240021 & 0 \\
\hline Brpf1 & IMAGE:640234 & Bromodomain and PHD finger containing, 1 & 0.30156377 & 0.72466093 & 0 \\
\hline EST & IMAGE:583910 & Expressed sequence tag & 0.14379641 & 0.7260223 & 0 \\
\hline LOC625360 & IMAGE:640316 & Similar to 2-cell-stage, variable group, member & 0.24664533 & 0.72602725 & 0 \\
\hline
\end{tabular}




\begin{tabular}{|c|c|c|c|c|c|}
\hline & & 3 & & & \\
\hline EST & IMAGE:640367 & Expressed sequence tag & 0.38464978 & 0.7281571 & 0 \\
\hline Tcrg-V4 & IMAGE:640763 & T-cell receptor gamma, variable 4 & 0.39765054 & 0.7284448 & 0 \\
\hline EST & IMAGE:582626 & Expressed sequence tag & 0.06477621 & 0.729255 & 0 \\
\hline EST & IMAGE:583291 & Expressed sequence tag & 0.2213351 & 0.73048735 & 0 \\
\hline EST & IMAGE:575704 & Expressed sequence tag & 0.13471045 & 0.73086864 & 0 \\
\hline Ly6a & IMAGE:574422 & Lymphocyte antigen 6 complex, locus A & 0.21610725 & 0.7323237 & 0 \\
\hline Ier3ip1 & IMAGE:583721 & $\begin{array}{l}\text { Immediate early response } 3 \text { interacting protein } \\
1\end{array}$ & 0.19199292 & 0.7327444 & 0 \\
\hline A230070E04Rik & IMAGE:641084 & RIKEN cDNA A230070E04 gene & 0.25124466 & 0.73326975 & 0 \\
\hline Ebag9 & IMAGE:641072 & $\begin{array}{l}\text { Estrogen receptor-binding fragment-associated } \\
\text { gene } 9\end{array}$ & 0.25006145 & 0.73356116 & 0 \\
\hline EST & IMAGE:583243 & Expressed sequence tag & 0.22121713 & 0.7376358 & 0 \\
\hline EST & IMAGE:576044 & Expressed sequence tag & 0.1698138 & 0.738246 & 0 \\
\hline H2-Eb1 & IMAGE:574155 & Histocompatibility 2, class II antigen E beta & 0.13192831 & 0.7383201 & 0 \\
\hline D430001N20 & IMAGE:583191 & Hypothetical protein D430001N20 & 0.15888494 & 0.73980457 & 0 \\
\hline Erf & IMAGE:583589 & Ets2 repressor factor & 0.19093207 & 0.74099076 & 0 \\
\hline $\operatorname{Itm} 2 b$ & IMAGE:640094 & Integral membrane protein $2 \mathrm{~B}$ & 0.14694008 & 0.7415464 & 0 \\
\hline Ogt & IMAGE:583774 & $\begin{array}{l}\text { O-linked N-acetylglucosamine (GlcNAc) } \\
\text { transferase (UDP-N- } \\
\text { acetylglucosamine:polypeptide-N- } \\
\text { acetylglucosaminyl transferase) }\end{array}$ & 0.29589108 & 0.74195945 & 0 \\
\hline EST & IMAGE:640921 & Expressed sequence tag & 0.1300807 & 0.74228555 & 0 \\
\hline
\end{tabular}




\begin{tabular}{|c|c|c|c|c|c|}
\hline EG629595 & IMAGE:640390 & Predicted gene, EG629595 & 0.30434254 & 0.7452167 & 0 \\
\hline Uros & IMAGE:583476 & Uroporphyrinogen III synthase & 0.0865208 & 0.7453261 & 0 \\
\hline Anxa1 & IMAGE:640284 & Annexin A1 & 0.09892646 & 0.74629813 & 0 \\
\hline Jmjd3 & IMAGE:640268 & Jumonji domain containing 3 & 0.24650778 & 0.74755526 & 0 \\
\hline In multiple clusters & IMAGE:640212 & & 0.09858139 & 0.7478466 & 0 \\
\hline Transcribed locus & IMAGE:583356 & & 0.08576527 & 0.7495674 & 0 \\
\hline Spg20 & IMAGE:573449 & $\begin{array}{l}\text { Spastic paraplegia 20, spartin (Troyer } \\
\text { syndrome) homolog (human) }\end{array}$ & 0.11443134 & 0.75315756 & 0 \\
\hline Psmb1 & IMAGE:640335 & $\begin{array}{l}\text { Proteasome (prosome, macropain) subunit, } \\
\text { beta type } 1\end{array}$ & 0.16476169 & 0.7539268 & 0 \\
\hline Transcribed locus & IMAGE:640171 & $\begin{array}{l}\text { Transcribed locus, weakly similar to } \\
\text { NP 039499.1 c oxidase } 1 \\
\text { [Schizosaccharomyces pombe] }\end{array}$ & 0.22697778 & 0.75461566 & 0 \\
\hline Rab22a & IMAGE:640602 & RAB22A, member RAS oncogene family & 0.13300219 & 0.75471085 & 0 \\
\hline Ccr9 & IMAGE:573572 & Heterogeneous nuclear ribonucleoprotein A1 & 0.10594203 & 0.7552143 & 0 \\
\hline 2010106G01Rik & IMAGE:575420 & RIKEN cDNA 2010106G01 gene & 0.13419901 & 0.7565941 & 0 \\
\hline Tada2l & IMAGE:583605 & $\begin{array}{l}\text { Transcriptional adaptor } 2 \text { (ADA2 homolog, } \\
\text { yeast)-like }\end{array}$ & 0.26568365 & 0.7566177 & 0 \\
\hline Transcribed locus & IMAGE:5181343 & $\begin{array}{l}\text { Transcribed locus, strongly similar to } \\
\text { NP_001036107.1 protein precursor [Macaca } \\
\text { mulatta] }\end{array}$ & 0.17050588 & 0.7569159 & 0 \\
\hline Rrp1b & IMAGE:575876 & $\begin{array}{l}\text { Ribosomal RNA processing } 1 \text { homolog B (S. } \\
\text { cerevisiae) }\end{array}$ & 0.15342484 & 0.7581555 & 0 \\
\hline Rnf185 & IMAGE:583933 & Ring finger protein 185 & 0.12291178 & 0.75857556 & 0 \\
\hline
\end{tabular}




\begin{tabular}{|c|c|c|c|c|c|}
\hline EST & IMAGE:583217 & Expressed sequence tag & 0.19015172 & 0.7589768 & 0 \\
\hline EST & IMAGE:640392 & Expressed sequence tag & 0.09947279 & 0.75992495 & 0 \\
\hline 9130004C02Rik & IMAGE:640356 & RIKEN cDNA 9130004C02 gene & 0.099256575 & 0.76088154 & 0 \\
\hline Cdkn2c & IMAGE:640222 & $\begin{array}{l}\text { Cyclin-dependent kinase inhibitor 2C (p18, } \\
\text { inhibits CDK4) }\end{array}$ & 0.303349 & 0.76103824 & 0 \\
\hline A430107D22Rik & IMAGE:574964 & RIKEN cDNA A430107D22 gene & 0.28273493 & 0.76106584 & 0 \\
\hline EST & IMAGE:641131 & Expressed sequence tag & 0.23088832 & 0.76224345 & 0 \\
\hline Nf2 & IMAGE:640467 & Neurofibromatosis 2 & 0.1650886 & 0.76268274 & 0 \\
\hline Rpl15 & IMAGE:583166 & Ribosomal protein L15 & 0.14001003 & 0.7632721 & 0 \\
\hline Trappc5 & IMAGE:640891 & Trafficking protein particle complex 5 & 0.23039232 & 0.7652603 & 0 \\
\hline EST & IMAGE:583216 & Expressed sequence tag & 0.17551346 & 0.7667527 & 0 \\
\hline Bccip & IMAGE:640916 & BRCA2 and CDKN1A interacting protein & 0.2507315 & 0.7671389 & 0 \\
\hline Tube1 & IMAGE:1447102 & Epsilon-tubulin 1 & 0.2587101 & 0.7691424 & 0 \\
\hline EST & IMAGE:575548 & Expressed sequence tag & 0.06989316 & 0.76957285 & 0 \\
\hline EST & IMAGE:583337 & Expressed sequence tag & 0.190408 & 0.76996815 & 0 \\
\hline EST & IMAGE:575870 & Expressed sequence tag & 0.15336819 & 0.7701433 & 0 \\
\hline EST & IMAGE:640815 & Expressed sequence tag & 0.16750668 & 0.77286106 & 0 \\
\hline Art4 & IMAGE:583437 & ADP-ribosyltransferase 4 & 0.26374847 & 0.7731826 & 0 \\
\hline 1300012G16Rik & IMAGE:640297 & RIKEN cDNA 1300012G16 gene & 0.12607153 & 0.77359635 & 0 \\
\hline EST & IMAGE:582988 & Expressed sequence tag & 0.17382735 & 0.7741013 & 0 \\
\hline In multiple clusters & IMAGE:640331 & & 0.3746578 & 0.77417654 & 0 \\
\hline EST & IMAGE:640900 & Expressed sequence tag & 0.18298908 & 0.774818 & 0 \\
\hline 1700029I01Rik & IMAGE:640379 & RIKEN cDNA 1700029I01 gene & 0.3757439 & 0.7750295 & 0 \\
\hline
\end{tabular}




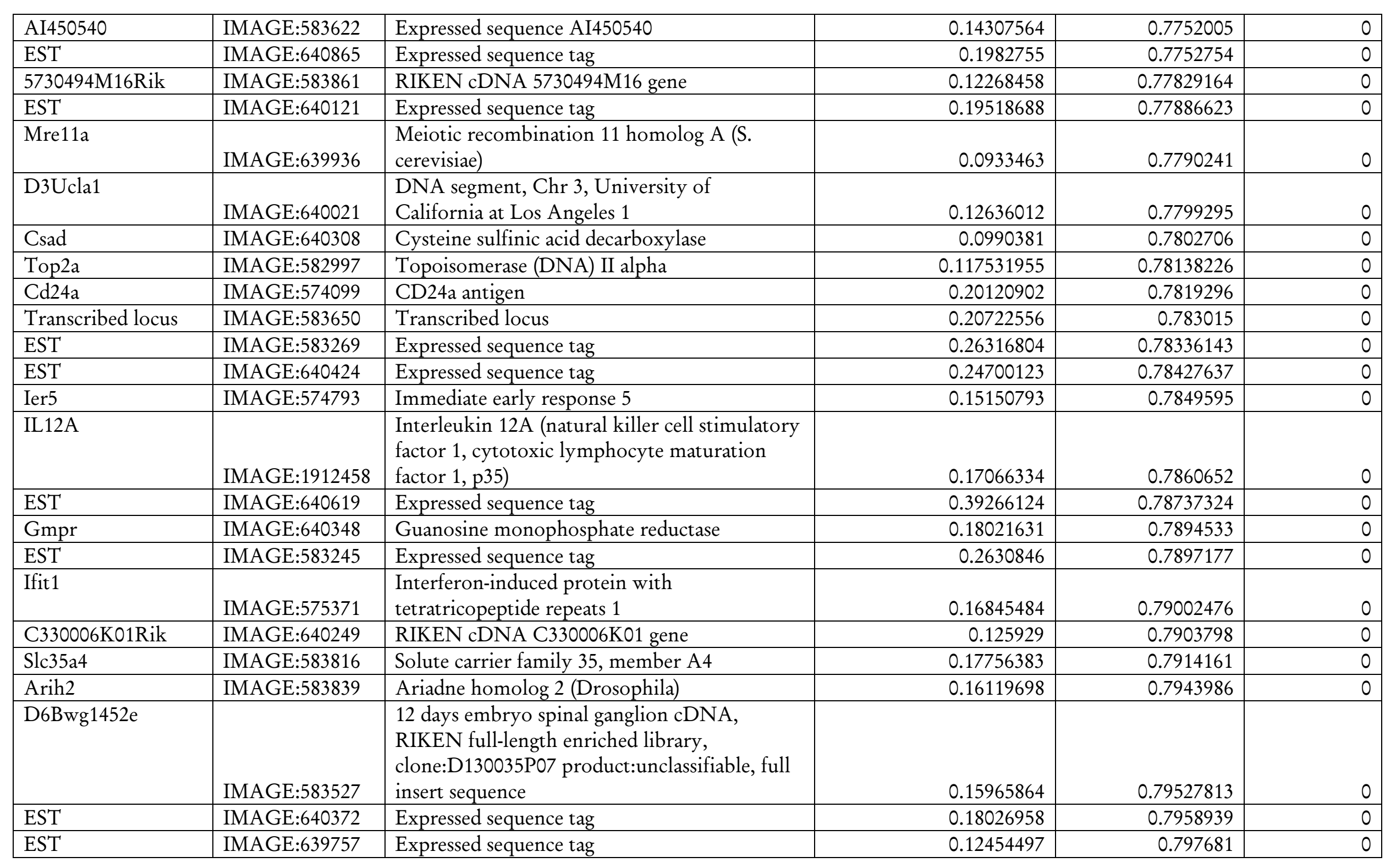




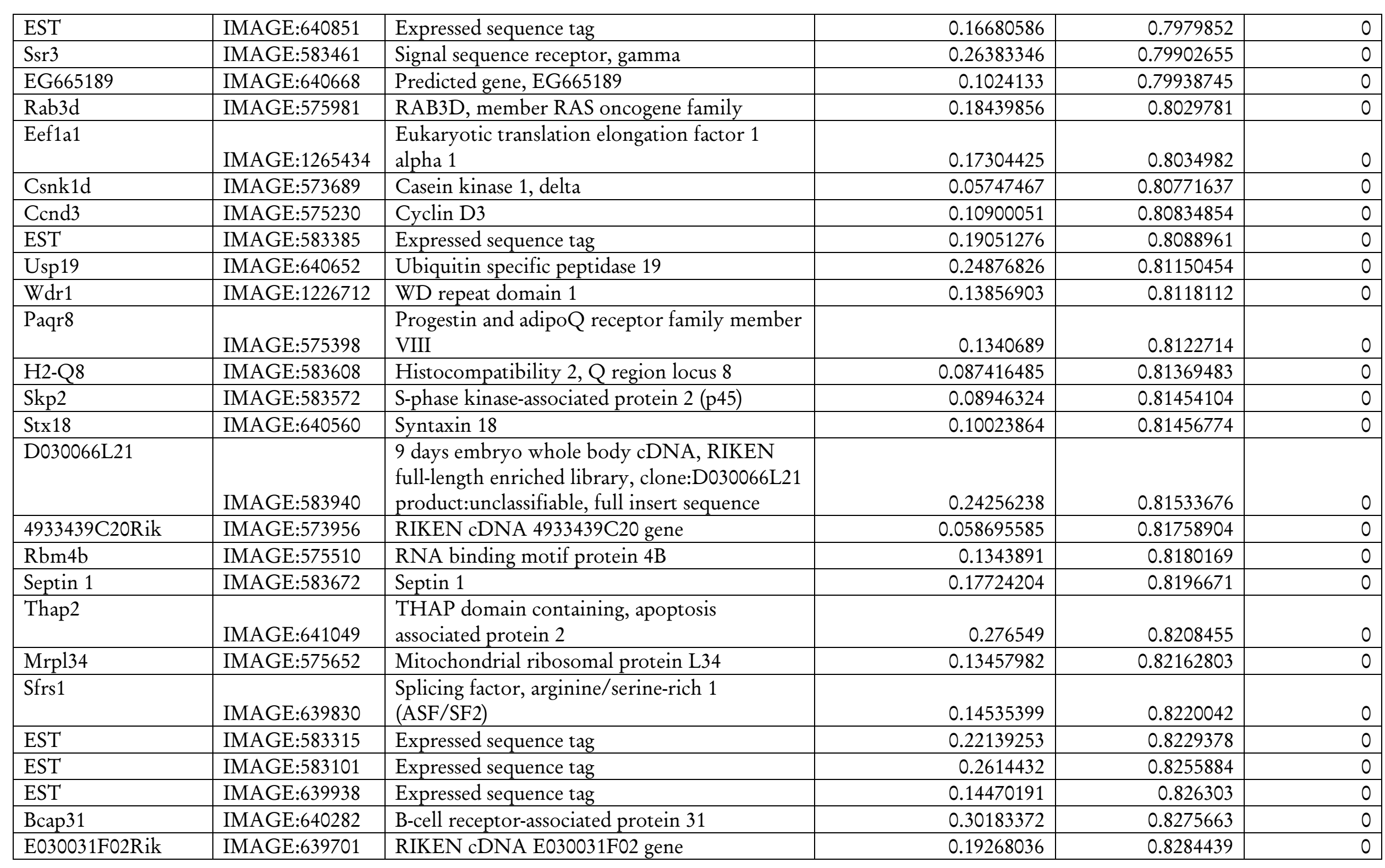




\begin{tabular}{|c|c|c|c|c|c|}
\hline$\overline{\text { EST }}$ & IMAGE:640791 & Expressed sequence tag & 0.16745125 & 0.82896 & 0 \\
\hline EST & IMAGE:640795 & Expressed sequence tag & 0.23020369 & 0.8294383 & 0 \\
\hline Ly6e & IMAGE:640890 & Lymphocyte antigen 6 complex, locus E & 0.2126839 & 0.83536303 & 0 \\
\hline Ankrd16 & IMAGE:583852 & Ankyrin repeat domain 16 & 0.17686474 & 0.8378268 & 0 \\
\hline Chic2 & IMAGE:582852 & Cysteine-rich hydrophobic domain 2 & 0.07983024 & 0.83809674 & 0 \\
\hline EST & IMAGE:640429 & Expressed sequence tag & 0.12863469 & 0.838762 & 0 \\
\hline 2810021B07Rik & IMAGE:640500 & RIKEN cDNA 2810021B07 gene & 0.10165408 & 0.84793746 & 0 \\
\hline Transcribed locus & IMAGE:583154 & Transcribed locus & 0.13970225 & 0.84813267 & 0 \\
\hline EST & IMAGE:640789 & Expressed sequence tag & 0.13078244 & 0.8493136 & 0 \\
\hline 2610307P16Rik & IMAGE:639668 & RIKEN cDNA 2610307P16 gene & 0.24365145 & 0.84994435 & 0 \\
\hline 2010001A14Rik & IMAGE:640493 & RIKEN cDNA 2010001A14 gene & 0.19601828 & 0.8510261 & 0 \\
\hline Transcribed locus & IMAGE:640343 & $\begin{array}{l}\text { Transcribed locus, strongly similar to } \\
\text { XP_001083304.1 similar to UPF3 regulator of } \\
\text { nonsense transcripts homolog B isoform } 1 \\
\text { isoform } 4 \text { [Macaca mulatta] }\end{array}$ & 0.3840242 & 0.8511316 & 0 \\
\hline Tmem115 & IMAGE:582843 & Transmembrane protein 115 & 0.15682927 & 0.8560752 & 0 \\
\hline Mettl3 & IMAGE:575022 & Methyltransferase-like 3 & 0.061360545 & 0.85629964 & 0 \\
\hline Transcribed locus & IMAGE:640294 & & 0.3037683 & 0.857805 & 0 \\
\hline Fkrp & IMAGE:640283 & CDNA, clone:Y2G0144I15, strand:unspecified & 0.3735732 & 0.85855323 & 0 \\
\hline Sh3gl1 & IMAGE:582991 & SH3-domain GRB2-like 1 & 0.21889967 & 0.86197454 & 0 \\
\hline Ddx39 & IMAGE:583491 & DEAD (Asp-Glu-Ala-Asp) box polypeptide 39 & 0.15872298 & 0.86287564 & 0 \\
\hline Tubgcp4 & IMAGE:583551 & Tubulin, gamma complex associated protein 4 & 0.15971231 & 0.8637202 & 0 \\
\hline Tpm3 & IMAGE:640122 & Tropomyosin 3, gamma & 0.21019569 & 0.8644068 & 0 \\
\hline EST & IMAGE:639766 & Expressed sequence tag & 0.29916385 & 0.8671045 & 0 \\
\hline 9130404D08Rik & IMAGE:583561 & RIKEN cDNA 9130404D08 gene & 0.12054103 & 0.86745816 & 0 \\
\hline Tomm20 & IMAGE:640575 & Translocase of outer mitochondrial membrane & 0.16616605 & 0.8684453 & 0 \\
\hline
\end{tabular}




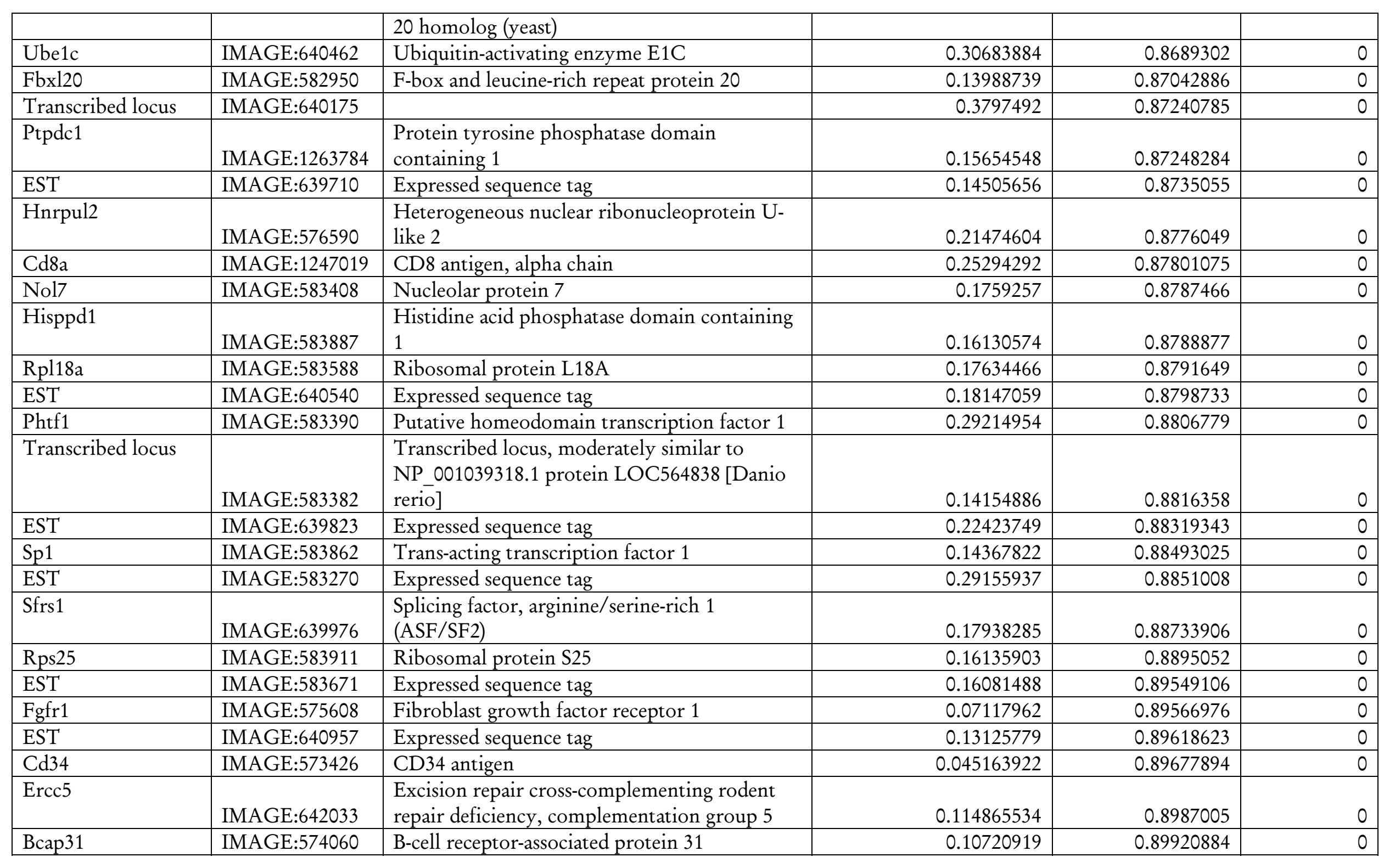




\begin{tabular}{|c|c|c|c|c|c|}
\hline EST & IMAGE:640428 & Expressed sequence tag & 0.10133358 & 0.89969724 & 0 \\
\hline Commd9 & IMAGE:640506 & COMM domain containing 9 & 0.21151488 & 0.90260774 & 0 \\
\hline Rab14 & IMAGE:640958 & RAB14, member RAS oncogene family & 0.1507684 & 0.9052191 & 0 \\
\hline EST & IMAGE:583897 & & 0.12162696 & 0.9080433 & 0 \\
\hline Transcribed locus & IMAGE:639874 & $\begin{array}{l}\text { Transcribed locus, strongly similar to } \\
\text { NP_ } 796188.2 \text { snRNP-specific protein, } 200 \mathrm{kDa} \\
\text { [Mus musculus] }\end{array}$ & 0.29808673 & 0.90835416 & 0 \\
\hline EST & IMAGE:582879 & Expressed sequence tag & 0.15772521 & 0.91267884 & 0 \\
\hline 2610318N02Rik & IMAGE:1263539 & RIKEN cDNA 2610318N02 gene & 0.15649268 & 0.9130029 & 0 \\
\hline EST & IMAGE:639739 & Expressed sequence tag & 0.22494186 & 0.91341853 & 0 \\
\hline EST & IMAGE:639735 & Expressed sequence tag & 0.16254744 & 0.9137181 & 0 \\
\hline Aldh9a1 & IMAGE:641104 & Aldehyde dehydrogenase 9 , subfamily A1 & 0.18404077 & 0.9152881 & 0 \\
\hline D2Ertd750e & IMAGE:575429 & $\begin{array}{l}\text { DNA segment, Chr 2, ERATO Doi 750, } \\
\text { expressed }\end{array}$ & 0.16855976 & 0.9155457 & 0 \\
\hline EST & IMAGE:583274 & Expressed sequence tag & 0.1403133 & 0.92276156 & 0 \\
\hline Transcribed locus & IMAGE:641128 & $\begin{array}{l}\text { Transcribed locus, weakly similar to } \\
\text { NP_006283.1 tumor susceptibility gene } 101 \\
\text { [Homo sapiens] }\end{array}$ & 0.18409316 & 0.9232936 & 0 \\
\hline Rps13 & IMAGE:640463 & Ribosomal protein S13 & 0.40038946 & 0.92348844 & 0 \\
\hline In multiple clusters & IMAGE:573361 & & 0.13653407 & 0.9253338 & 0 \\
\hline Ptrh1 & IMAGE:583513 & $\begin{array}{l}\text { Peptidyl-tRNA hydrolase } 1 \text { homolog (S. } \\
\text { cerevisiae) }\end{array}$ & 0.11914009 & 0.92612064 & 0 \\
\hline Psmc3 & IMAGE:583912 & $\begin{array}{l}\text { Proteasome (prosome, macropain) 26S } \\
\text { subunit, ATPase } 3\end{array}$ & 0.17777064 & 0.92723286 & 0 \\
\hline Triobp & IMAGE:640097 & TRIO and F-actin binding protein & 0.19513556 & 0.92870533 & 0 \\
\hline
\end{tabular}




\begin{tabular}{|c|c|c|c|c|c|}
\hline Rasa3 & IMAGE:582174 & RAS p21 protein activator 3 & 0.25257158 & 0.92892563 & 0 \\
\hline Gpbp1 & IMAGE:583064 & GC-rich promoter binding protein 1 & 0.23717466 & 0.92908806 & 0 \\
\hline $\mathrm{Cd} 27$ & IMAGE:583084 & $\mathrm{CD}$ antigen 27 & 0.1739877 & 0.9302863 & 0 \\
\hline EST & IMAGE:640040 & Expressed sequence tag & 0.2447632 & 0.93166554 & 0 \\
\hline LOC433894 & IMAGE:639996 & Hypothetical LOC433894 & 0.09562077 & 0.9323258 & 0 \\
\hline EST & IMAGE:640767 & Expressed sequence tag & 0.16659042 & 0.9332772 & 0 \\
\hline Fen1 & IMAGE:639819 & Flap structure specific endonuclease 1 & 0.16190428 & 0.9359021 & 0 \\
\hline EST & IMAGE:640884 & Expressed sequence tag & 0.10485231 & 0.93814737 & 0 \\
\hline EST & IMAGE:583936 & Expressed sequence tag & 0.17782243 & 0.93868136 & 0 \\
\hline EST & IMAGE:575844 & Expressed sequence tag & 0.1531439 & 0.9395625 & 0 \\
\hline Transcribed locus & IMAGE:2410765 & & 0.17093271 & 0.93994594 & 0 \\
\hline Taf6 & IMAGE:640288 & $\begin{array}{l}\text { TAF6 RNA polymerase II, TATA box } \\
\text { binding protein (TBP)-associated factor }\end{array}$ & 0.18090148 & 0.9403317 & 0 \\
\hline Ppp2ca & IMAGE:583384 & $\begin{array}{l}\text { Protein phosphatase } 2 \text { (formerly 2A), catalytic } \\
\text { subunit, alpha isoform }\end{array}$ & 0.17587511 & 0.94072795 & 0 \\
\hline EST & IMAGE:576526 & Expressed sequence tag & 0.20067982 & 0.94323826 & 0 \\
\hline Transcribed locus & IMAGE:640725 & & 0.27521336 & 0.9439663 & 0 \\
\hline D4Wsu53e & IMAGE:583453 & $\begin{array}{l}\text { DNA segment, Chr 4, Wayne State University } \\
53 \text {, expressed }\end{array}$ & 0.12015055 & 0.9442281 & 0 \\
\hline Ndufab1 & IMAGE:639895 & $\begin{array}{l}\text { NADH dehydrogenase (ubiquinone) } 1 \\
\text { alpha/beta subcomplex, } 1\end{array}$ & 0.22441117 & 0.946922 & 0 \\
\hline Ppp3cb & IMAGE:583115 & $\begin{array}{l}\text { Protein phosphatase } 3 \text {, catalytic subunit, beta } \\
\text { isoform }\end{array}$ & 0.33328447 & 0.9492225 & 0 \\
\hline EST & IMAGE:583031 & Expressed sequence tag & 0.33570895 & 0.9518504 & 0 \\
\hline EST & IMAGE:640384 & Expressed sequence tag & 0.18110855 & 0.9521329 & 0 \\
\hline EST & IMAGE:640664 & Expressed sequence tag & 0.24770363 & 0.95290923 & 0 \\
\hline Apobec3 & IMAGE:582807 & Apolipoprotein B editing complex 3 & 0.15761167 & 0.95400316 & 0 \\
\hline EST & IMAGE:640876 & Expressed sequence tag & 0.18293494 & 0.9558044 & 0 \\
\hline
\end{tabular}




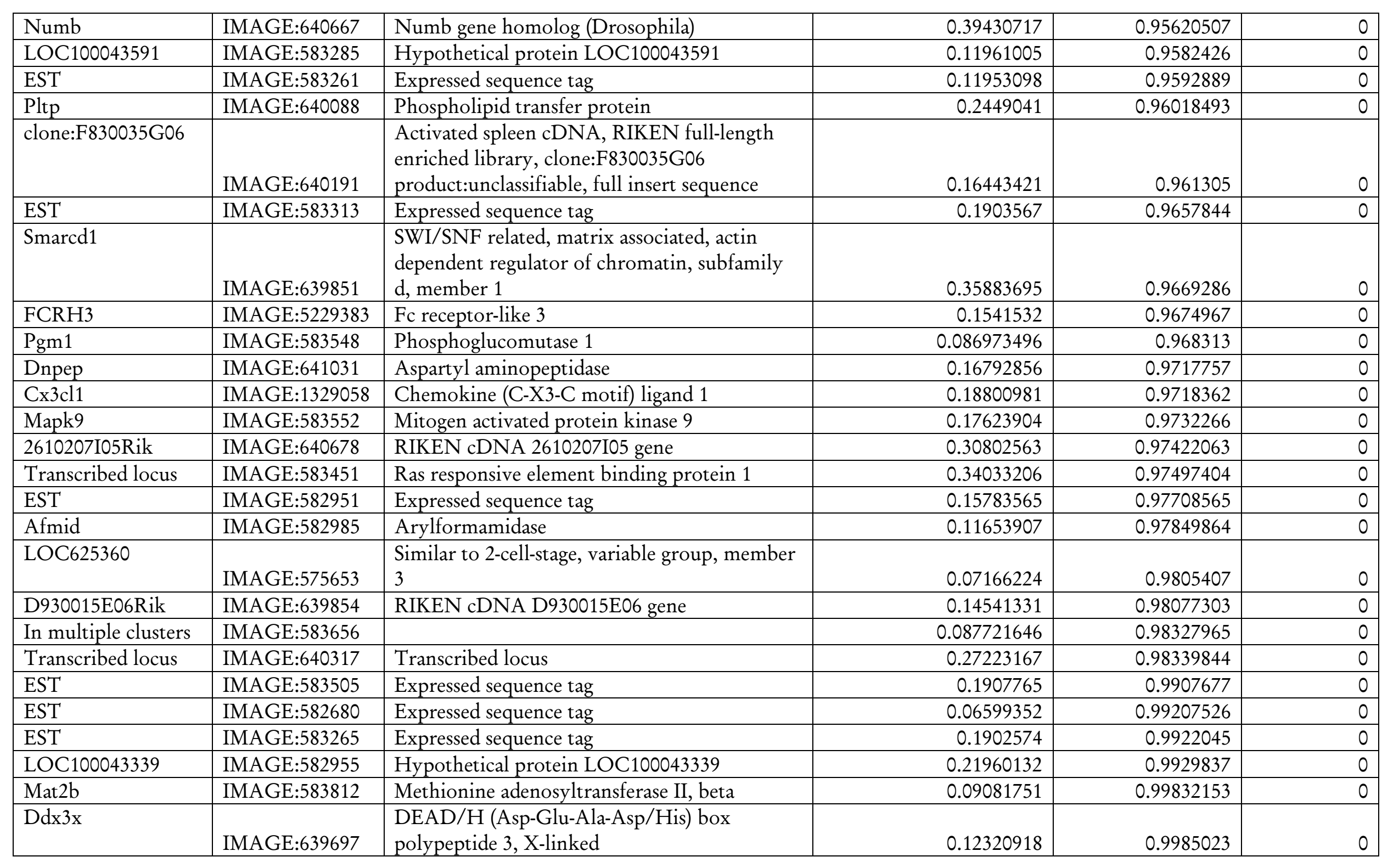




\begin{tabular}{|c|c|c|c|c|c|}
\hline EST & IMAGE:640642 & Expressed sequence tag & 0.30565807 & 0.9985243 & 0 \\
\hline Anxa5 & IMAGE:576596 & Annexin A5 & 0.21480387 & 1.0008115 & 0 \\
\hline EST & IMAGE:640396 & Expressed sequence tag & 0.18116067 & 1.0056394 & 0 \\
\hline Rpl7a & IMAGE:582916 & Ribosomal protein L7a & 0.17367032 & 1.0064209 & 0 \\
\hline EST & IMAGE:583481 & Expressed sequence tag & 0.19072291 & 1.0064325 & 0 \\
\hline Tapt1 & IMAGE:576636 & $\begin{array}{l}\text { Transmembrane anterior posterior } \\
\text { transformation } 1\end{array}$ & 0.2150888 & 1.0071121 & 0 \\
\hline EST & IMAGE:583053 & & 0.26127622 & 1.009449 & 0 \\
\hline Transcribed locus & IMAGE:582947 & Transcribed locus & 0.33190817 & 1.0095013 & 0 \\
\hline LOC626877 & IMAGE:640460 & Similar to zinc finger protein 709 & 0.24819928 & 1.0097693 & 0 \\
\hline EST & IMAGE:583497 & Expressed sequence tag & 0.2626778 & 1.0108321 & 0 \\
\hline Transcribed locus & IMAGE:582793 & Transcribed locus & 0.11587919 & 1.0117749 & 0 \\
\hline Kpna2 & IMAGE:640444 & Karyopherin (importin) alpha 2 & 0.181264 & 1.0162456 & 0 \\
\hline Cd72 & IMAGE:573570 & CD72 antigen & 0.15460835 & 1.0293872 & 0 \\
\hline EST & IMAGE:640472 & Expressed sequence tag & 0.24713854 & 1.0327979 & 0 \\
\hline E130112N10Rik & IMAGE:640155 & RIKEN cDNA E130112N10 gene & 0.16352412 & 1.0332108 & 0 \\
\hline Tuba2 & IMAGE:582927 & Tubulin, alpha 2 & 0.15778112 & 1.0343908 & 0 \\
\hline Cebpg & IMAGE:641074 & Transcribed locus & 0.15212524 & 1.0360912 & 0 \\
\hline EST & IMAGE:583044 & Expressed sequence tag & 0.081285626 & 1.0366639 & 0 \\
\hline Mecp2 & IMAGE:576274 & Methyl CpG binding protein 2 & 0.18573175 & 1.0384046 & 0 \\
\hline EST & IMAGE:640838 & Expressed sequence tag & 0.15048277 & 1.0384777 & 0 \\
\hline EG665189 & IMAGE:582828 & Predicted gene, EG665189 & 0.079648115 & 1.0400876 & 0 \\
\hline Nde1 & IMAGE:640079 & $\begin{array}{l}\text { Nuclear distribution gene } \mathrm{E} \text { homolog } 1 \text { (A } \\
\text { nidulans) }\end{array}$ & 0.37741485 & 1.0413917 & 0 \\
\hline
\end{tabular}




\begin{tabular}{|c|c|c|c|c|c|}
\hline EST & IMAGE:640800 & Expressed sequence tag & 0.103029124 & 1.0455887 & 0 \\
\hline EST & IMAGE:582869 & Expressed sequence tag & 0.1881667 & 1.0476729 & 0 \\
\hline Zmynd10 & IMAGE:1225083 & Zinc finger, MYND domain containing 10 & 0.11537553 & 1.0510406 & 0 \\
\hline Ctsl & IMAGE:583530 & Cathepsin L & 0.20613752 & 1.0514634 & 0 \\
\hline Fstl1 & IMAGE:583623 & Follistatin-like 1 & 0.16070542 & 1.0539619 & 0 \\
\hline Golt1b & IMAGE:639999 & Golgi transport 1 homolog B (S. cerevisiae) & 0.16314551 & 1.0546305 & 0 \\
\hline Stip1 & IMAGE:583886 & Stress-induced phosphoprotein 1 & 0.14373931 & 1.0614493 & 0 \\
\hline Pot1a & IMAGE:640128 & Protection of telomeres $1 \mathrm{~A}$ & 0.0963532 & 1.0616719 & 0 \\
\hline Tbl1xr1 & IMAGE:583935 & Transducin (beta)-like 1X-linked receptor 1 & 0.16141373 & 1.0632274 & 0 \\
\hline EST & IMAGE:640248 & $\begin{array}{l}\text { Glycosylphosphatidylinositol specific } \\
\text { phospholipase D1 }\end{array}$ & 0.09695831 & 1.0643129 & 0 \\
\hline EST & IMAGE:583813 & Expressed sequence tag & 0.12253151 & 1.0655004 & 0 \\
\hline Sfrs1 & IMAGE:583110 & $\begin{array}{l}\text { Splicing factor, arginine/serine-rich } 1 \\
\text { (ASF/SF2) }\end{array}$ & 0.20380194 & 1.076277 & 0 \\
\hline Fxyd2 & IMAGE:640559 & $\begin{array}{l}\text { FXYD domain-containing ion transport } \\
\text { regulator } 2\end{array}$ & 0.40434322 & 1.0858704 & 0 \\
\hline EST & IMAGE:583428 & Expressed sequence tag & 0.086212896 & 1.0912954 & 0 \\
\hline In multiple clusters & IMAGE:583796 & & 0.24216327 & 1.0917478 & 0 \\
\hline EST & IMAGE:640477 & Expressed sequence tag & 0.12877384 & 1.0925419 & 0 \\
\hline 1700029I01Rik & IMAGE:583028 & RIKEN cDNA 1700029I01 gene & 0.23795384 & 1.0932949 & 0 \\
\hline Anxa4 & IMAGE:583430 & Annexin A4 & 0.14167187 & 1.0968199 & 0 \\
\hline 0610009K11Rik & IMAGE:582885 & RIKEN cDNA 0610009K11 gene & 0.26077446 & 1.0974934 & 0 \\
\hline Pkig & IMAGE:583036 & Adenosine deaminase & 0.1738811 & 1.0975935 & 0 \\
\hline
\end{tabular}




\begin{tabular}{|c|c|c|c|c|c|}
\hline 4930566A11Rik & IMAGE:583433 & RIKEN cDNA 4930566A11 gene & 0.19061698 & 1.0984402 & 0 \\
\hline D4Wsu53e & IMAGE:583112 & $\begin{array}{l}\text { DNA segment, Chr 4, Wayne State University } \\
53 \text {, expressed }\end{array}$ & 0.23724103 & 1.0998384 & 0 \\
\hline EST & IMAGE:641097 & Expressed sequence tag & 0.27674356 & 1.1003822 & 0 \\
\hline EST & IMAGE:640539 & Expressed sequence tag & 0.1652494 & 1.105236 & 0 \\
\hline Hexb & IMAGE:575852 & Hexosaminidase B & 0.15319869 & 1.1071315 & 0 \\
\hline Cebpg & IMAGE:641074 & Transcribed locus & 0.3104874 & 1.1078917 & 0 \\
\hline EST & IMAGE:575254 & Expressed sequence tag & 0.10909994 & 1.1111922 & 0 \\
\hline EST & IMAGE:640241 & Expressed sequence tag & 0.19545148 & 1.1112188 & 0 \\
\hline EST & IMAGE:583502 & Expressed sequence tag & 0.14185527 & 1.1160715 & 0 \\
\hline EST & IMAGE:583581 & Expressed sequence tag & 0.26560113 & 1.1213808 & 0 \\
\hline EST & IMAGE:583908 & Expressed sequence tag & 0.09136899 & 1.1254189 & 0 \\
\hline EST & IMAGE:583130 & Expressed sequence tag & 0.13963741 & 1.1279197 & 0 \\
\hline Transcribed locus & IMAGE:640334 & & 0.1475255 & 1.1293075 & 0 \\
\hline Ankrd10 & IMAGE:583182 & Ankyrin repeat domain 10 & 0.2045607 & 1.1305966 & 0 \\
\hline Cmpk & IMAGE:640631 & Cytidylate kinase & 0.4075747 & 1.1318333 & 0 \\
\hline Spg20 & IMAGE:582846 & $\begin{array}{l}\text { Spastic paraplegia 20, spartin (Troyer } \\
\text { syndrome) homolog (human) }\end{array}$ & 0.2032074 & 1.1364282 & 0 \\
\hline Capn2 & IMAGE:583248 & Calpain 2 & 0.08251614 & 1.1409152 & 0 \\
\hline Ntn1 & IMAGE:583376 & Netrin 1 & 0.23888218 & 1.1454443 & 0 \\
\hline $\mathrm{A} 430079 \mathrm{~K} 02$ & IMAGE:640409 & $\begin{array}{l}0 \text { day neonate thymus cDNA, RIKEN full- } \\
\text { length enriched library, clone:A430079K02 } \\
\text { product:unclassifiable, full insert sequence }\end{array}$ & 0.19665025 & 1.1476575 & 0 \\
\hline EST & IMAGE:583192 & Expressed sequence tag & 0.17546168 & 1.1511065 & 0 \\
\hline
\end{tabular}




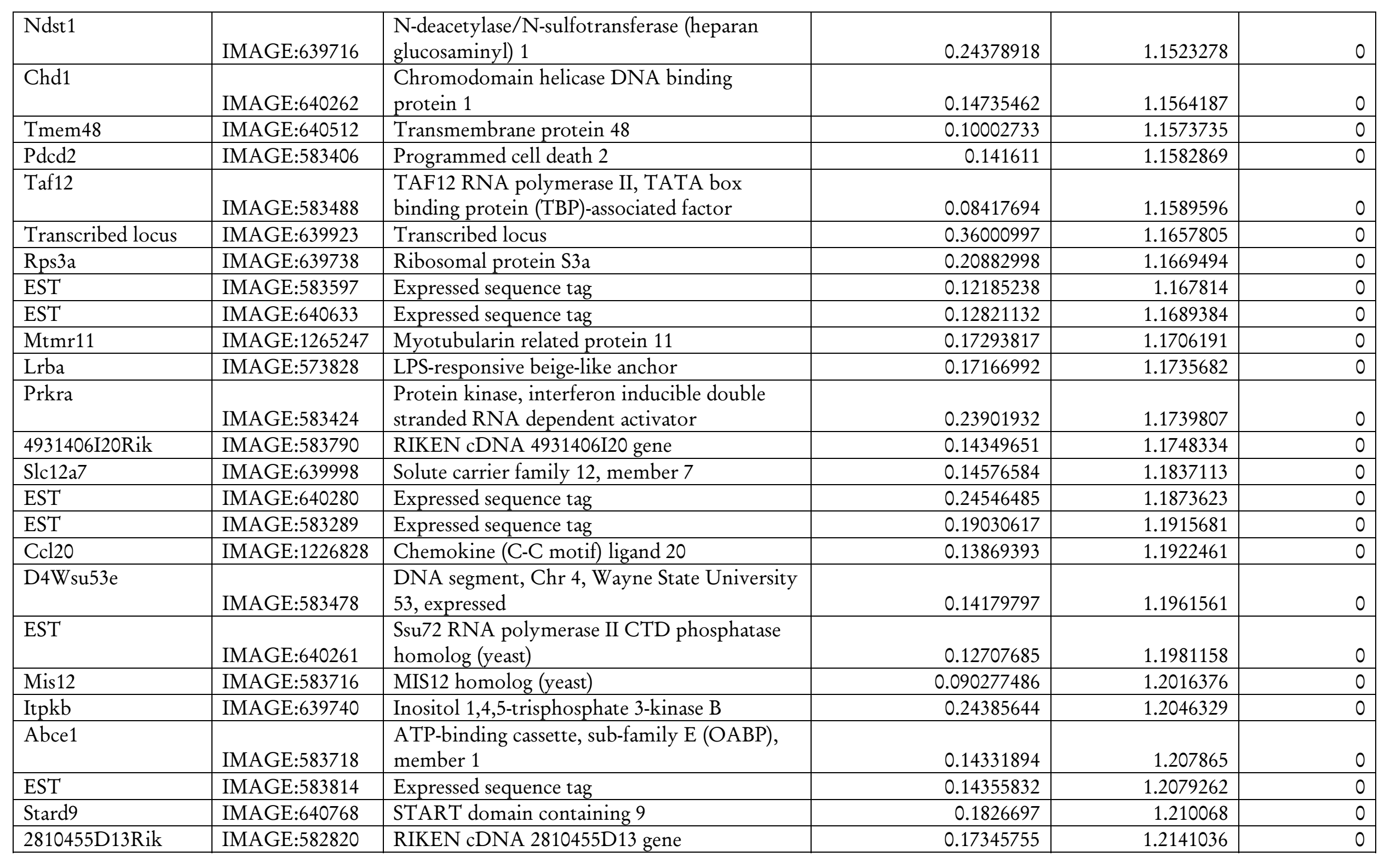




\begin{tabular}{|c|c|c|c|c|c|}
\hline EST & IMAGE:640824 & Expressed sequence tag & 0.10313236 & 1.2171714 & 0 \\
\hline EST & IMAGE:640252 & Expressed sequence tag & 0.18000229 & 1.2227986 & 0 \\
\hline 4932433N03Rik & IMAGE:640355 & PR domain containing 10 & 0.37522268 & 1.2281287 & 0 \\
\hline EST & IMAGE:640313 & Expressed sequence tag & 0.19560425 & 1.2315154 & 0 \\
\hline Tuba1b & IMAGE:639633 & Tubulin, alpha 2 & 0.26689938 & 1.232416 & 0 \\
\hline Eif4g2 & IMAGE:640625 & $\begin{array}{l}\text { Eukaryotic translation initiation factor } 4 \text {, } \\
\text { gamma } 2\end{array}$ & 0.19712143 & 1.2330875 & 0 \\
\hline EST & IMAGE:583422 & Expressed sequence tag & 0.20505205 & 1.2448963 & 0 \\
\hline Lck & IMAGE:640179 & Lymphocyte protein tyrosine kinase & 0.16357891 & 1.2512286 & 0 \\
\hline EST & IMAGE:583106 & Expressed sequence tag & 0.13957363 & 1.2535152 & 0 \\
\hline Glrx5 & IMAGE:583838 & Glutaredoxin 5 homolog (S. cerevisiae) & 0.14361861 & 1.2561904 & 0 \\
\hline EST & IMAGE:640848 & Expressed sequence tag & 0.10323192 & 1.2563207 & 0 \\
\hline Cyb5b & IMAGE:640762 & Cytochrome b5 type B & 0.30639276 & 1.2566386 & 0 \\
\hline 3110001D03Rik & IMAGE:641030 & RIKEN cDNA 3110001D03 gene & 0.15093622 & 1.2862916 & 0 \\
\hline Egr1 & IMAGE:576356 & Early growth response 1 & 0.18588513 & 1.2877073 & 0 \\
\hline Ndufab1 & IMAGE:583543 & $\begin{array}{l}\text { NADH dehydrogenase (ubiquinone) } 1 \text {, } \\
\text { alpha/beta subcomplex, } 1\end{array}$ & 0.22104767 & 1.3321646 & 0 \\
\hline H2-K1 & IMAGE:640137 & Histocompatibility 2, K1, K region & 0.27011466 & 1.3347989 & 0 \\
\hline 2410131K14Rik & IMAGE:583765 & RIKEN cDNA 2410131K14 gene & 0.12238359 & 1.3359904 & 0 \\
\hline Tmco6 & IMAGE:583157 & Transmembrane and coiled-coil domains 6 & 0.18868993 & 1.3363899 & 0 \\
\hline EST & IMAGE:575672 & Expressed sequence tag & 0.16898367 & 1.3396982 & 0 \\
\hline Nap1l1 & IMAGE:583621 & Nucleosome assembly protein 1 -like 1 & 0.12192973 & 1.353248 & 0 \\
\hline 2410127E18Rik & IMAGE:583407 & RIKEN cDNA 2410127E18 gene & 0.1593836 & 1.3600667 & 0 \\
\hline
\end{tabular}




\begin{tabular}{|c|c|c|c|c|c|}
\hline EST & IMAGE:640872 & Expressed sequence tag & 0.10333227 & 1.3640214 & 0 \\
\hline EST & IMAGE:583189 & Expressed sequence tag & 0.1192999 & 1.367478 & 0 \\
\hline Pex12 & IMAGE:640739 & Peroxisomal biogenesis factor 12 & 0.3967752 & 1.3871258 & 0 \\
\hline EST & IMAGE:583361 & Expressed sequence tag & 0.1904587 & 1.3879939 & 0 \\
\hline EST & IMAGE:576310 & RIKEN cDNA 2810021B07 gene & 0.18578498 & 1.3972731 & 0 \\
\hline Sema7a & IMAGE:583573 & $\begin{array}{l}\text { Sema domain, immunoglobulin domain (Ig), } \\
\text { and GPI membrane anchor, (semaphorin) 7A }\end{array}$ & 0.121779755 & 1.4004148 & 0 \\
\hline Myh11 & IMAGE:583021 & Myosin, heavy polypeptide 11 , smooth muscle & 0.117609486 & 1.4048539 & 0 \\
\hline Lsp1 & IMAGE:640873 & Lymphocyte specific 1 & 0.12994066 & 1.4113812 & 0 \\
\hline Pbrm1 & IMAGE:640336 & Polybromo 1 & 0.18100296 & 1.4261597 & 0 \\
\hline $\begin{array}{l}\text { OTTMUSG000000 } \\
15615\end{array}$ & IMAGE:573984 & Predicted gene, OTTMUSG00000015615 & 0.18677296 & 1.4386475 & 0 \\
\hline Rpl27a & IMAGE:583237 & Ribosomal protein L27a & 0.11945638 & 1.4410703 & 0 \\
\hline EST & IMAGE:640636 & Expressed sequence tag & 0.18167754 & 1.4471576 & 0 \\
\hline Ndufa11 & IMAGE:640025 & $\begin{array}{l}\text { NADH dehydrogenase (ubiquinone) } 1 \text { alpha } \\
\text { subcomplex } 11\end{array}$ & 0.1949766 & 1.453027 & 0 \\
\hline Sfrs1 & IMAGE:640898 & $\begin{array}{l}\text { Splicing factor, arginine/serine-rich } 1 \\
\text { (ASF/SF2) }\end{array}$ & 0.14979707 & 1.4552816 & 0 \\
\hline Rpl6 & IMAGE:583113 & Ribosomal protein L6 & 0.2602955 & 1.4553547 & 0 \\
\hline 4933411K20Rik & IMAGE:641854 & RIKEN cDNA 4933411K20 gene & 0.07570058 & 1.4596387 & 0 \\
\hline EST & IMAGE:583924 & Expressed sequence tag & 0.17696965 & 1.4621696 & 0 \\
\hline
\end{tabular}




\begin{tabular}{|c|c|c|c|c|c|}
\hline EST & IMAGE:582998 & Expressed sequence tag & 0.13994968 & 1.4656422 & 0 \\
\hline EST & IMAGE:640563 & Expressed sequence tag & 0.16530347 & 1.477091 & 0 \\
\hline Transcribed locus & IMAGE:640718 & Predicted gene, EG329160 & 0.14933823 & 1.5124165 & 0 \\
\hline Pcbp3 & IMAGE:583766 & Poly $(\mathrm{rC})$ binding protein 3 & 0.14343545 & 1.517046 & 0 \\
\hline Pdk3 & IMAGE:578105 & Pyruvate dehydrogenase kinase, isoenzyme 3 & 0.23485824 & 1.5186045 & 0 \\
\hline EST & IMAGE:583400 & 5'-3' exoribonuclease 1 & 0.23895131 & 1.5261348 & 0 \\
\hline Rbm39 & IMAGE:640923 & RNA binding motif protein 39 & 0.16696563 & 1.5497329 & 0 \\
\hline Tapt1 & IMAGE:640665 & $\begin{array}{l}\text { Transmembrane anterior posterior } \\
\text { transformation } 1\end{array}$ & 0.27362913 & 1.5509655 & 0 \\
\hline EST & IMAGE:583200 & Expressed sequence tag & 0.08217306 & 1.5649662 & 0 \\
\hline EST & IMAGE:640981 & Expressed sequence tag & 0.13132267 & 1.5652509 & 0 \\
\hline Hist1h2bc & IMAGE:640662 & Histone cluster $1, \mathrm{H} 2 \mathrm{bc}$ & 0.2110765 & 1.5770954 & 0 \\
\hline EST & IMAGE:576256 & Expressed sequence tag & 0.18558083 & 1.658207 & 0 \\
\hline EST & IMAGE:640521 & Expressed sequence tag & 0.2730733 & 1.6630465 & 0 \\
\hline Adhfe1 & IMAGE:640899 & Alcohol dehydrogenase, iron containing, 1 & 0.16691019 & 1.6720959 & 0 \\
\hline EST & IMAGE:583675 & Expressed sequence tag & 0.22322412 & 1.6949353 & 0 \\
\hline 9430015G10Rik & IMAGE:583737 & RIKEN cDNA 9430015G10 gene & 0.26484284 & 1.7045926 & 0 \\
\hline Myg1 & IMAGE:640034 & Melanocyte proliferating gene 1 & 0.14588425 & 1.731795 & 0 \\
\hline D14Ertd449e & IMAGE:577726 & Transcribed locus & 0.25452778 & 1.7631146 & 0 \\
\hline Zhx1 & IMAGE:640278 & Zinc fingers and homeoboxes protein 1 & 0.20975778 & 1.7648783 & 0 \\
\hline EST & IMAGE:641143 & Expressed sequence tag & 0.23014303 & 1.7739022 & 0 \\
\hline Transcribed locus & IMAGE:640875 & Transcribed locus & 0.16685823 & 1.7804123 & 0 \\
\hline EST & IMAGE:640984 & Expressed sequence tag & 0.18383066 & 1.7832661 & 0 \\
\hline
\end{tabular}


ANEXO I

\begin{tabular}{|c|c|c|c|c|c|}
\hline Es2el & IMAGE:583108 & Expressed sequence 2 embryonic lethal & 0.17403734 & 1.7871766 & 0 \\
\hline EST & IMAGE:640337 & Expressed sequence tag & 0.19565637 & 1.8290895 & 0 \\
\hline EG621205 & IMAGE:640982 & Predicted gene, EG621205 & 0.15082297 & 1.8387327 & 0 \\
\hline Ttll4 & IMAGE:582821 & Tubulin tyrosine ligase-like family, member 4 & 0.18806146 & 1.8657908 & 0 \\
\hline Hist1h2bc & IMAGE:640662 & Histone cluster $1, \mathrm{H} 2 \mathrm{bc}$ & 0.07307641 & 1.8738339 & 0 \\
\hline EST & IMAGE:583213 & Expressed sequence tag & 0.11937629 & 1.9202455 & 0 \\
\hline Rnf187 & IMAGE:640076 & Ring finger protein 187 & 0.24595205 & 1.9577457 & 0 \\
\hline Ncf1 & IMAGE:5371913 & Neutrophil cytosolic factor 1 & 0.25331965 & 1.972282 & 0 \\
\hline EST & IMAGE:583636 & Expressed sequence tag & 0.17644823 & 1.978074 & 0 \\
\hline Mycbp & IMAGE:583915 & Ras-related GTP binding C & 0.22382583 & 1.9908214 & 0 \\
\hline Sfrs1 & IMAGE:583038 & $\begin{array}{l}\text { Splicing factor, arginine/serine-rich } 1 \\
\text { (ASF/SF2) }\end{array}$ & 0.20363934 & 1.9977032 & 0 \\
\hline EST & IMAGE:640817 & Expressed sequence tag & 0.19817033 & 1.9988683 & 0 \\
\hline Cib1 & IMAGE:583939 & Calcium and integrin binding 1 (calmyrin) & 0.22388275 & 2.0442023 & 0 \\
\hline Sfrs1 & IMAGE:582848 & $\begin{array}{l}\text { Splicing factor, arginine/serine-rich } 1 \\
\text { (ASF/SF2) }\end{array}$ & 0.23659152 & 2.2645428 & 0 \\
\hline Dtymk & IMAGE:583035 & Deoxythymidylate kinase & 0.15727472 & 2.8086443 & 0 \\
\hline EST & IMAGE:639730 & Expressed sequence tag & 0.2974373 & 3.5508795 & 0 \\
\hline
\end{tabular}


Anexo II 
Tabela III. Genes diferencialmente expressos comparando-se células mTEC controles versus células mTEC transfectadas com RNAi anti-Aire (FDR 15\%, p-value 0,015).

\begin{tabular}{|c|c|c|c|c|}
\hline Gene Symbol & CloneID & Gene Name & Fold change & q-value (\%) \\
\hline EST & IMAGE:640598 & Expressed sequence tag & 1.0673177 & 14.5946665 \\
\hline Gclm & IMAGE:639968 & Glutamate-cysteine ligase, modifier subunit & 1.1114856 & 12.903029 \\
\hline $\mathrm{E} 2 \mathrm{f} 2$ & IMAGE:640754 & E2F transcription factor 2 & 1.1284692 & 12.903029 \\
\hline 2610040C18Rik & $\begin{array}{l}\text { IMAGE:122576 } \\
8\end{array}$ & Apoptosis-inducing, TAF9-like domain 1 & 1.06998 & 12.903029 \\
\hline EST & IMAGE:583312 & Expressed sequence tag & 1.0601645 & 12.903029 \\
\hline EST & IMAGE:639827 & Expressed sequence tag & 1.1019533 & 12.085992 \\
\hline Myg1 & IMAGE:583514 & Melanocyte proliferating gene 1 & 1.1121532 & 12.085992 \\
\hline Klhl7 & IMAGE:583190 & $\begin{array}{l}\text { Gamma-aminobutyric acid (GABA-A) receptor-associated protein- } \\
\text { like } 2\end{array}$ & 1.0723306 & 12.085992 \\
\hline Txnrd1 & IMAGE:583921 & Thioredoxin reductase 1 & 1.0930426 & 12.085992 \\
\hline EST & IMAGE:583308 & Expressed sequence tag & 1.0649359 & 12.085992 \\
\hline EST & IMAGE:641140 & Expressed sequence tag & 1.0681186 & 12.085992 \\
\hline EST & IMAGE:640351 & Expressed sequence tag & 1.1232543 & 12.085992 \\
\hline 1110008H02Rik & IMAGE:640371 & Transcribed locus & 1.0701028 & 12.085992 \\
\hline $\mathrm{H} 13$ & IMAGE:640912 & Histocompatibility 13 & 1.0737796 & 12.085992 \\
\hline EST & IMAGE:640865 & Expressed sequence tag & 1.1486661 & 12.085992 \\
\hline
\end{tabular}




\begin{tabular}{|c|c|c|c|c|}
\hline 1500002B03Rik & $\begin{array}{l}\text { IMAGE: } 133038 \\
5\end{array}$ & WD repeat domain 53 & 1.1449281 & 12.085992 \\
\hline EST & IMAGE:582951 & Expressed sequence tag & 1.1534444 & 10.909013 \\
\hline EST & IMAGE:640943 & Transcribed locus & 1.1063399 & 10.909013 \\
\hline Nde1 & IMAGE:640079 & Nuclear distribution gene E homolog 1 (A nidulans) & 1.1183379 & 10.943718 \\
\hline EST & IMAGE:640860 & Expressed sequence tag & 1.091564 & 10.134216 \\
\hline EST & IMAGE:583031 & Expressed sequence tag & 1.1456674 & 10.134216 \\
\hline Bcap31 & IMAGE:640282 & B-cell receptor-associated protein 31 & 1.0808171 & 10.134216 \\
\hline Mmp14 & IMAGE:573066 & Matrix metallopeptidase 14 (membrane-inserted) & 1.1140016 & 10.134216 \\
\hline Hist1h2bc & IMAGE:640662 & Histone cluster $1, \mathrm{H} 2 \mathrm{bc}$ & 1.1471213 & 10.134216 \\
\hline 1110037N09Rik & IMAGE:583451 & Ras responsive element binding protein 1 & 1.1069003 & 10.134216 \\
\hline 4921537D05Rik & IMAGE:639871 & RIKEN cDNA 4921537D05 gene & 1.1277622 & 9.724821 \\
\hline EST & IMAGE:640381 & Expressed sequence tag & 1.1173592 & 9.724821 \\
\hline EST & IMAGE:640299 & Expressed sequence tag & 1.0907763 & 9.724821 \\
\hline 3110037I16Rik & IMAGE:640889 & RIKEN cDNA 3110037I16 gene & 1.1730123 & 9.1921625 \\
\hline EST & IMAGE:583900 & Expressed sequence tag & 1.1453668 & 9.1921625 \\
\hline EST & IMAGE:138013 & Expressed sequence tag & 1.08235 & 9.1921625 \\
\hline EST & IMAGE:641123 & Expressed sequence tag & 1.1028172 & 8.697915 \\
\hline Eaf1 & IMAGE:640226 & ELL associated factor 1 & 1.070029 & 7.769566 \\
\hline EST & IMAGE:640838 & Expressed sequence tag & 1.15003 & 6.6869216 \\
\hline
\end{tabular}




\begin{tabular}{|c|c|c|c|c|}
\hline Dusp2 & IMAGE:640913 & Dual specificity phosphatase 2 & 1.1603421 & 6.6869216 \\
\hline EST & IMAGE:639637 & Expressed sequence tag & 1.0655534 & 4.846363 \\
\hline EST & IMAGE:641137 & Expressed sequence tag & 1.0804759 & 4.846363 \\
\hline EST & IMAGE:640121 & Expressed sequence tag & 1.0771161 & 4.846363 \\
\hline EST & IMAGE:640280 & Expressed sequence tag & 1.1345134 & 4.846363 \\
\hline EST & IMAGE:640664 & Expressed sequence tag & 1.1900343 & 4.846363 \\
\hline 6330415G19Rik & IMAGE:583538 & Zinc finger protein 213 & 1.0928538 & 4.7988496 \\
\hline Myc & IMAGE:574902 & Myelocytomatosis oncogene & 1.1011529 & 3.979534 \\
\hline Mrpl34 & IMAGE:575652 & Mitochondrial ribosomal protein L34 & 1.0884858 & 4.0286636 \\
\hline EST & IMAGE:583053 & Expressed sequence tag & 1.1728827 & 4.0286636 \\
\hline Syngr2 & IMAGE:640773 & Synaptogyrin 2 & 1.1226083 & 3.352621 \\
\hline Rps13 & IMAGE:640463 & Ribosomal protein S13 & 1.1350834 & 3.352621 \\
\hline EST & IMAGE:640521 & Expressed sequence tag & 1.1595614 & 3.352621 \\
\hline EST & IMAGE:640602 & Expressed sequence tag & 1.1412392 & 3.352621 \\
\hline 2900076A07Rik & IMAGE:583769 & RIKEN cDNA 2900076A07 gene & 1.1678199 & 3.708202 \\
\hline EST & IMAGE:583456 & Expressed sequence tag & 1.1011477 & 3.199233 \\
\hline $\mathrm{H} 2-\mathrm{K} 1$ & IMAGE:640137 & Histocompatibility 2, $\mathrm{K} 1, \mathrm{~K}$ region & 1.1671582 & 3.199233 \\
\hline EST & IMAGE:582983 & Expressed sequence tag & 1.1746738 & 3.199233 \\
\hline EST & IMAGE:576044 & Expressed sequence tag & 1.1233515 & 3.3991852 \\
\hline
\end{tabular}




\begin{tabular}{|c|c|c|c|c|}
\hline EST & IMAGE:640173 & Expressed sequence tag & 1.1573058 & 3.5469759 \\
\hline Numb & IMAGE:640667 & Numb gene homolog (Drosophila) & 1.1834155 & 0 \\
\hline FASLG & $\begin{array}{l}\text { IMAGE:517859 } \\
6\end{array}$ & Fas ligand (TNF superfamily, member 6) & 0.7508043 & 0 \\
\hline Rab3d & IMAGE:575981 & RAB3D, member RAS oncogene family & 0.78198445 & 0 \\
\hline Bag2 & IMAGE:573075 & Bcl2-associated athanogene 2 & 0.8758778 & 0 \\
\hline FCRH3 & $\begin{array}{l}\text { IMAGE:522938 } \\
3\end{array}$ & Fc receptor-like 3 & 0.7801735 & 0 \\
\hline EST & IMAGE:640539 & Expressed sequence tag & 0.862176 & 0 \\
\hline IL12A & $\begin{array}{l}\text { IMAGE: } 191245 \\
8\end{array}$ & $\begin{array}{l}\text { Interleukin 12A (natural killer cell stimulatory factor } 1 \text {, cytotoxic } \\
\text { lymphocyte maturation factor } 1, \mathrm{p} 35 \text { ) }\end{array}$ & 0.8045339 & 0 \\
\hline Transcribed locus & IMAGE:204515 & $\begin{array}{l}\text { Similar to C-C chemokine receptor type } 2 \text { (C-C CKR-2) (CC-CKR- } \\
\text { 2) (CCR-2) (CCR2) (Monocyte chemoattractant protein } 1 \text { receptor) } \\
\text { (MCP-1-R) (CD192 antigen) }\end{array}$ & 0.85200554 & 0 \\
\hline TNF & $\begin{array}{l}\text { IMAGE:521313 } \\
4\end{array}$ & Tumor necrosis factor (TNF superfamily, member 2) & 0.81887746 & 0 \\
\hline Grb2 & IMAGE:575387 & Growth factor receptor bound protein 2 & 0.8562132 & 0 \\
\hline CCR7 & IMAGE:518075 & Chemokine (C-C motif) receptor 7 & 0.7866933 & 0 \\
\hline
\end{tabular}




\begin{tabular}{|c|c|c|c|c|}
\hline & 8 & & & \\
\hline Spg20 & IMAGE:573449 & Spastic paraplegia 20, spartin (Troyer syndrome) homolog (human) & 0.8325986 & 0 \\
\hline $\begin{array}{l}\text { In multiple } \\
\text { clusters }\end{array}$ & IMAGE:573897 & & 0.8534656 & 0 \\
\hline Myb & IMAGE:575702 & Myeloblastosis oncogene & 0.90313786 & 0 \\
\hline Ifit1 & IMAGE:575371 & Interferon-induced protein with tetratricopeptide repeats 1 & 0.8970446 & 0 \\
\hline EST & IMAGE:576310 & Expressed sequence tag & 0.84747314 & 0 \\
\hline D10Ertd610e & IMAGE:576334 & DNA segment, Chr 10, ERATO Doi 610, expressed & 0.8760762 & 0 \\
\hline Rela & IMAGE:574694 & V-rel reticuloendotheliosis viral oncogene homolog A (avian) & 0.89305645 & 2.4721346 \\
\hline Ifit2 & IMAGE:574088 & Interferon-induced protein with tetratricopeptide repeats 2 & 0.890293 & 2.4721346 \\
\hline Transcribed locus & IMAGE:575254 & & 0.81951696 & 2.3994248 \\
\hline EST & IMAGE:583181 & Expressed sequence tag & 0.90183985 & 2.0918062 \\
\hline EST & IMAGE:640424 & Expressed sequence tag & 0.89434534 & 2.0395112 \\
\hline Tbx21 & \begin{tabular}{|l|} 
IMAGE:138129 \\
7
\end{tabular} & Transcribed locus & 0.86731595 & 1.989767 \\
\hline Chd9 & IMAGE:639708 & Chromodomain helicase DNA binding protein 9 & 0.91148907 & 1.9423915 \\
\hline Mecp2 & IMAGE:576274 & Methyl CpG binding protein 2 & 0.915491 & 3.6257975 \\
\hline Cdca8 & IMAGE:576454 & Cell division cycle associated 8 & 0.89017075 & 3.6257975 \\
\hline Polr3d & IMAGE:573740 & Polymerase (RNA) III (DNA directed) polypeptide D & 0.9152492 & 3.6257975 \\
\hline 2810475A17Rik & IMAGE:640512 & Transmembrane protein 48 & 0.90270126 & 3.4715083 \\
\hline
\end{tabular}




\begin{tabular}{|c|c|c|c|c|}
\hline Cnot10 & IMAGE:576406 & CCR4-NOT transcription complex, subunit 10 & 0.91797125 & 2.9665616 \\
\hline 5930434B04Rik & IMAGE:583644 & RIKEN cDNA 5930434B04 gene & 0.9124771 & 2.9665616 \\
\hline EST & IMAGE:582312 & Expressed sequence tag & 0.8512796 & 2.9665616 \\
\hline D14Ertd449e & IMAGE:577726 & DNA segment, Chr 14, ERATO Doi 449, expressed & 0.9229027 & 2.9665616 \\
\hline EST & IMAGE:575208 & Expressed sequence tag & 0.8866187 & 4.012153 \\
\hline Stx18 & IMAGE: 640560 & Syntaxin 18 & 0.8706409 & 4.012153 \\
\hline Ap2a2 & IMAGE:639674 & Adaptor protein complex AP-2, alpha 2 subunit & 0.90311587 & 4.012153 \\
\hline 3110031B13Rik & IMAGE:583227 & RIKEN cDNA 3110031B13 gene & 0.9055848 & 4.012153 \\
\hline Sfrs1 & IMAGE:583015 & Splicing factor, arginine/serine-rich 1 (ASF/SF2) & 0.7740291 & 4.012153 \\
\hline CD80 & $\begin{array}{l}\text { IMAGE:518134 } \\
3\end{array}$ & CD80 molecule & 0.88077635 & 3.7652512 \\
\hline Tusc2 & IMAGE:583440 & Hyaluronoglucosaminidase 2 & 0.9165395 & 3.7652512 \\
\hline 2410016F01Rik & IMAGE:640076 & Ring finger protein 187 & 0.92492443 & 3.7652512 \\
\hline Vamp1 & IMAGE:573892 & Vesicle-associated membrane protein 1 & 0.892336 & 3.6528556 \\
\hline EST & IMAGE:575844 & Expressed sequence tag & 0.91412157 & 3.5469759 \\
\hline Arl12 & IMAGE:581822 & ADP-ribosylation factor-like 5C & 0.87418383 & 3.5469759 \\
\hline FASLG & $\begin{array}{l}\text { IMAGE:517859 } \\
6\end{array}$ & Fas ligand (TNF superfamily, member 6) & 0.8506223 & 4.409754 \\
\hline 2010106G01Rik & IMAGE:575420 & RIKEN cDNA 2010106G01 gene & 0.9245134 & 4.350957 \\
\hline EST & IMAGE:640562 & Expressed sequence tag & 0.90648896 & 3.9315877 \\
\hline 2610510L01Rik & IMAGE:574272 & Zinc finger, matrin type 5 & 0.9106585 & 4.7988496 \\
\hline Bcas3 & IMAGE:583447 & Breast carcinoma amplified sequence 3 & 0.9313725 & 4.583171 \\
\hline EST & IMAGE:575796 & Expressed sequence tag & 0.93010813 & 4.583171 \\
\hline Nol6 & IMAGE:583756 & Nucleolar protein family 6 (RNA-associated) & 0.94241685 & 4.583171 \\
\hline Il16 & IMAGE:573050 & Interleukin 16 & 0.8774276 & 4.583171 \\
\hline Anxa4 & IMAGE:583430 & Annexin A4 & 0.92426145 & 4.532247 \\
\hline Btg1 & IMAGE:574654 & B-cell translocation gene 1, anti-proliferative & 0.7811802 & 4.482442 \\
\hline Misc12 & IMAGE:583716 & MIS12 homolog (yeast) & 0.89525664 & 4.4337196 \\
\hline
\end{tabular}




\begin{tabular}{|c|c|c|c|c|}
\hline Gzma & IMAGE:572830 & Granzyme A & 0.8852119 & 5.4909916 \\
\hline 1700095N21Rik & IMAGE:640611 & Stam binding protein like 1 & 0.9253962 & 5.4909916 \\
\hline Rab10 & IMAGE:573868 & RAB10, member RAS oncogene family & 0.8931526 & 5.4909916 \\
\hline EST & IMAGE:640027 & Expressed sequence tag & 0.93267274 & 6.1570144 \\
\hline Hspa8 & IMAGE:575712 & Heat shock protein 8 & 0.92555046 & 6.1570144 \\
\hline 2810455D13Rik & IMAGE:582820 & RIKEN cDNA 2810455D13 gene & 0.91810757 & 6.0994725 \\
\hline Rhebl1 & IMAGE:576372 & Ras homolog enriched in brain like 1 & 0.8832183 & 6.042996 \\
\hline EST & IMAGE:583299 & Expressed sequence tag & 0.903509 & 6.6146307 \\
\hline Tmem 60 & IMAGE:639684 & Transmenbrane protein 60 & 0.9299942 & 6.6146307 \\
\hline $\mathrm{H} 2-\mathrm{Eb} 1$ & IMAGE:574155 & Histocompatibility 2, class II antigen E beta & 0.8886254 & 6.6146307 \\
\hline Dibd1 & IMAGE:639947 & $\begin{array}{l}\text { Asparagine-linked glycosylation } 9 \text { homolog (yeast, alpha } 1,2 \\
\text { mannosyltransferase) }\end{array}$ & 0.9231943 & 6.5555716 \\
\hline EST & IMAGE:582894 & Expressed sequence tag & 0.9101722 & 6.4405613 \\
\hline Abca5 & IMAGE:582867 & ATP-binding cassette, sub-family A (ABC1), member 5 & 0.91500676 & 6.4405613 \\
\hline EST & IMAGE:575632 & Expressed sequence tag & 0.93499315 & 6.3845563 \\
\hline Btg1 & IMAGE:582825 & B-cell translocation gene 1, anti-proliferative & 0.9065552 & 6.9726872 \\
\hline EST & IMAGE:640794 & Expressed sequence tag & 0.88052225 & 6.9726872 \\
\hline 2210404O07Rik & IMAGE:573122 & RIKEN cDNA 2210404007 gene & 0.9250655 & 6.6869216 \\
\hline EST & IMAGE:640040 & Expressed sequence tag & 0.911263 & 6.6869216 \\
\hline B930006L02Rik & IMAGE:640875 & Transcribed locus & 0.86167 & 6.6869216 \\
\hline Lef1 & IMAGE:575374 & Lymphoid enhancer binding factor 1 & 0.90452534 & 6.6325564 \\
\hline Pank2 & IMAGE:583251 & Pantothenate kinase 2 (Hallervorden-Spatz syndrome) & 0.9153259 & 7.8317227 \\
\hline EST & IMAGE:640717 & Expressed sequence tag & 0.888545 & 7.8317227 \\
\hline EST & IMAGE:640843 & Expressed sequence tag & 0.92703193 & 7.5888786 \\
\hline Ankrd10 & IMAGE:583182 & Ankyrin repeat domain 10 & 0.916508 & 7.5888786 \\
\hline $\mathrm{Cd} 8 \mathrm{a}$ & $\begin{array}{l}\text { IMAGE:124701 } \\
9\end{array}$ & CD8 antigen, alpha chain & 0.93137217 & 7.5888786 \\
\hline Sit & IMAGE:576098 & Suppression inducing transmembrane adaptor 1 & 0.9147729 & 8.095769 \\
\hline
\end{tabular}




\begin{tabular}{|c|c|c|c|c|}
\hline EST & IMAGE:576142 & Expressed sequence tag & 0.9321476 & 8.095769 \\
\hline Mre11a & IMAGE:639936 & Meiotic recombination 11 homolog A (S. cerevisiae) & 0.8711923 & 8.034437 \\
\hline 6820402O20Rik & IMAGE:640923 & RNA binding motif protein 39 & 0.86235416 & 8.587415 \\
\hline Cybb & IMAGE:583187 & Cytochrome b-245, beta polypeptide & 0.89804614 & 8.762344 \\
\hline Rbl2 & IMAGE:576225 & Retinoblastoma-like 2 & 0.918051 & 8.762344 \\
\hline Cd83 & IMAGE:574651 & CD83 antigen & 0.89952916 & 9.1921625 \\
\hline EST & IMAGE:641087 & Expressed sequence tag & 0.9061627 & 9.1921625 \\
\hline Hel308 & IMAGE:581959 & Helicase, mus308-like (Drosophila) & 0.90254235 & 9.1921625 \\
\hline Klhl20 & IMAGE:582908 & Kelch-like 20 (Drosophila) & 0.9313501 & 9.724821 \\
\hline EST & IMAGE:582322 & Expressed sequence tag & 0.9115154 & 9.724821 \\
\hline Atpaf1 & IMAGE:639636 & ATP synthase mitochondrial F1 complex assembly factor 1 & 0.9414004 & 9.724821 \\
\hline Park7 & IMAGE:583034 & Parkinson disease (autosomal recessive, early onset) 7 & 0.9238755 & 9.724821 \\
\hline Rhoa & IMAGE:572818 & $\begin{array}{l}\text { CDNA, clone:Y0G0104B14, strand:minus, reference:ENSEMBL: } \\
\text { Mouse-Transcript-NST:ENSMUST00000007959, based on BLAT } \\
\text { search }\end{array}$ & 0.896466 & 9.724821 \\
\hline Transcribed locus & IMAGE:575780 & Chemokine (C-C motif) ligand 25 & 0.93027353 & 10.575243 \\
\hline EST & \begin{tabular}{|l|} 
IMAGE: 136223 \\
2 \\
\end{tabular} & Expressed sequence tag & 0.9037807 & 10.943718 \\
\hline C730042F17Rik & IMAGE:640700 & ORM1-like 1 (S. cerevisiae) & 0.8992265 & 10.909013 \\
\hline $\begin{array}{l}\text { In multiple } \\
\text { clusters }\end{array}$ & IMAGE:573267 & RPA interacting protein & 0.9084455 & 10.909013 \\
\hline Dbp & IMAGE:583416 & D site albumin promoter binding protein & 0.9236056 & 10.909013 \\
\hline Actr1a & IMAGE:583567 & ARP1 actin-related protein 1 homolog A (yeast) & 0.90226614 & 10.909013 \\
\hline Dnajc7 & IMAGE:573602 & DnaJ (Hsp40) homolog, subfamily C, member 7 & 0.8710109 & 10.909013 \\
\hline Nlk & IMAGE:582998 & Nemo like kinase & 0.9272456 & 11.317518 \\
\hline $\operatorname{Ddx} 3 \mathrm{x}$ & IMAGE:639697 & DEAD/H (Asp-Glu-Ala-Asp/His) box polypeptide 3, X-linked & 0.9183363 & 12.837532 \\
\hline Elk4 & IMAGE:583566 & ELK4, member of ETS oncogene family & 0.8972935 & 12.987931 \\
\hline EST & IMAGE:583908 & Expressed sequence tag & 0.8932793 & 12.987931 \\
\hline
\end{tabular}


ANEXO II

\begin{tabular}{|l|l|l|r|r|}
\hline EST & IMAGE:576476 & Expressed sequence tag & 0.9310019 & 12.987931 \\
\hline Gucy2d & IMAGE:582819 & Guanylate cyclase 2d & 0.9221744 & 12.987931 \\
\hline Ncf4 & IMAGE:576061 & Neutrophil cytosolic factor 4 & 0.9115133 & 14.5946665 \\
\hline Pot1 & IMAGE:640128 & Protection of telomeres 1A & 0.92453456 & 14.5946665 \\
\hline Btbd1 & IMAGE:582942 & BTB (POZ) domain containing 1 & 0.9308438 & 14.5946665 \\
\hline E130112N10Rik & IMAGE:640155 & CD antigen 27 & 0.8934426 & 14.5946665 \\
\hline EST & IMAGE:641158 & Expressed sequence tag & 0.8800882 & 14.5946665 \\
\hline EST & IMAGE:576500 & Expressed sequence tag & 0.94008034 & 14.5946665 \\
\hline Slc22a7 & IMAGE:574190 & Solute carrier family 22 (organic anion transporter), member 7 & 0.9212938 & 14.5946665 \\
\hline EST & IMAGE:583342 & Expressed sequence tag & 0.9084793 & 14.5946665 \\
\hline Sh3gl1 & IMAGE:582991 & SH3-domain GRB2-like 1 & 0.90447086 & 14.5946665 \\
\hline Ier5 & IMAGE:574793 & Immediate early response 5 & 0.9171551 & 14.5946665 \\
\hline EST & IMAGE:640956 & Expressed sequence tag & 0.8923168 & 14.5946665 \\
\hline EST & IMAGE:640851 & Expressed sequence tag & 0.9186528 & 14.5946665 \\
\hline EST & IMAGE:583661 & Expressed sequence tag & 0.9314311 & 14.5946665 \\
\hline Brpf1 & IMAGE:640234 & Bromodomain and PHD finger containing, 1 & 0.93281096 & 14.5946665 \\
\hline Hexb & IMAGE:575852 & Hexosaminidase B & 0.9403777 & 14.5946665 \\
\hline
\end{tabular}


Anexo III 
Tabela IV. Genes da rede controle que fazem interação com o nó gênico Gucy2d e o tipo de interação.

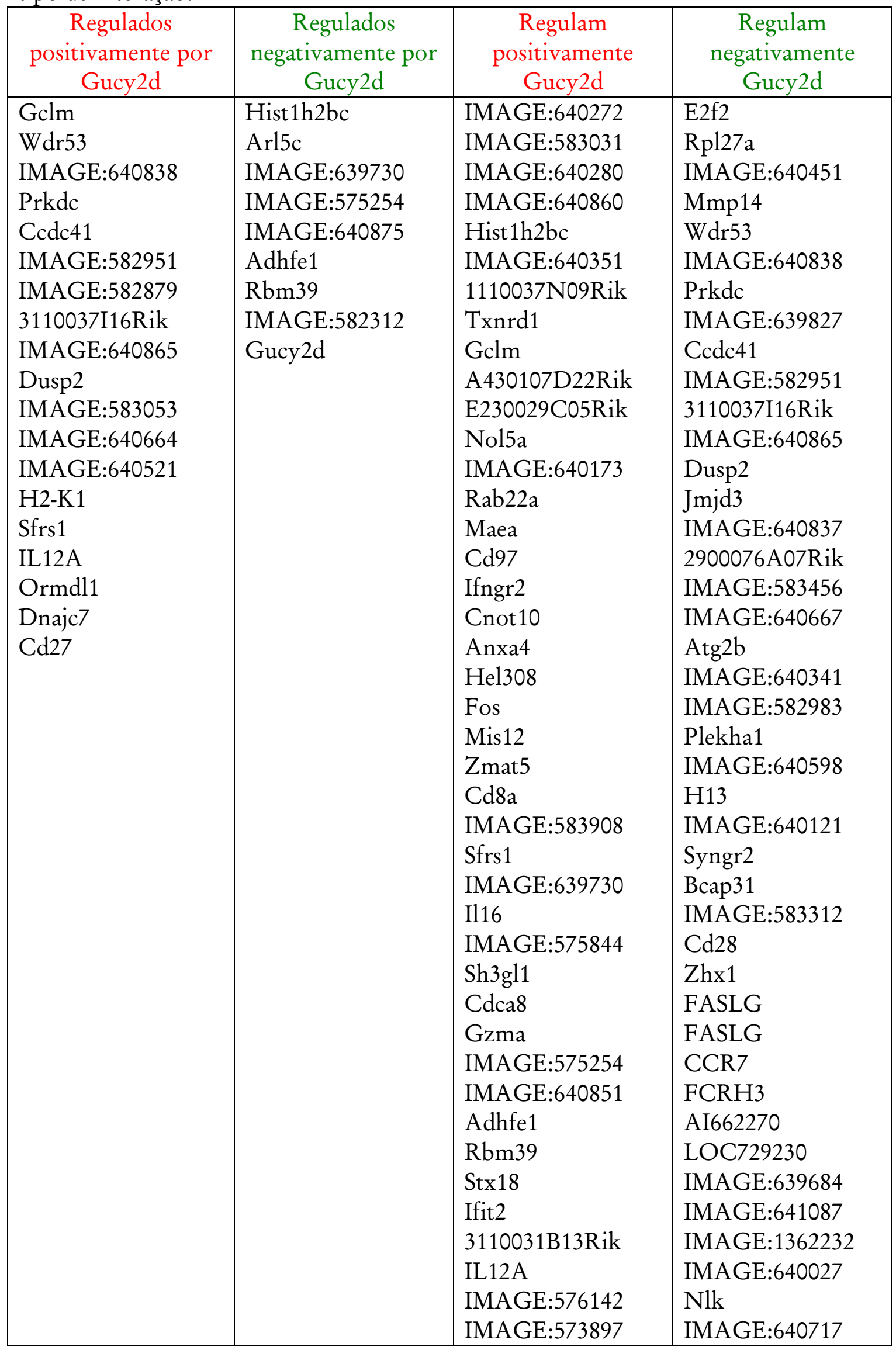




\begin{tabular}{|c|c|c|c|}
\hline & & $\begin{array}{l}\text { Ifit1 } \\
\text { Rela } \\
\text { IMAGE:575632 } \\
\text { Grb2 } \\
\text { Ccl25 } \\
\text { IMAGE:583299 } \\
\text { Btbd1 } \\
\text { Clec1b } \\
\text { IMAGE:583181 } \\
\text { Slc22a7 } \\
\text { Hnrpa1 } \\
\text { IMAGE:575796 } \\
\text { Bcas3 } \\
\text { Myb } \\
\text { Polr3d } \\
\text { Rab10 } \\
\text { Vamp1 } \\
\text { Actr1a } \\
\text { IMAGE:582312 } \\
\text { IMAGE:582322 } \\
\text { Rbl2 } \\
\text { IMAGE:583661 } \\
\text { IMAGE:572818 } \\
\text { Hspa8 } \\
\text { Hexb }\end{array}$ & $\begin{array}{l}\text { IMAGE:640843 } \\
\text { Arl5c } \\
\text { Lef1 } \\
\text { 2210404O07Rik } \\
\text { Sit } \\
\text { IMAGE:640875 } \\
\text { IMAGE:639781 } \\
\text { IMAGE:640539 } \\
\text { Stambpl1 } \\
\text { Nol6 } \\
\text { Ptgs2 } \\
\text { IMAGE:577726 } \\
\text { IMAGE:573361 } \\
\text { Ap2a2 } \\
\text { Abca5 } \\
\text { Cd83 } \\
\text { Lims1 } \\
\text { 2810455D13Rik } \\
\text { Spg20 } \\
\text { CD80 } \\
\text { H2-Eb1 } \\
\text { Ier5 } \\
\text { Gucy2d } \\
\text { Ormd11 } \\
\text { IMAGE:641158 } \\
\text { Dnajc7 } \\
\text { Cd27 } \\
\text { IMAGE:640956 } \\
\text { Mre11a } \\
\text { Pot1a } \\
\text { Btg1 }\end{array}$ \\
\hline
\end{tabular}


Tabela V. Genes da rede experimental que fazem interação com o nó gênico Gucy2d e o tipo de interação.

\begin{tabular}{|c|c|c|c|}
\hline $\begin{array}{c}\text { Regulados } \\
\text { positivamente por } \\
\text { Gucy2d }\end{array}$ & $\begin{array}{c}\text { Regulados } \\
\text { negativamente por } \\
\text { Gucy2d }\end{array}$ & $\begin{array}{c}\text { Regulam } \\
\text { positivamente } \\
\text { Gucy2d } \\
\end{array}$ & $\begin{array}{c}\text { Regulam } \\
\text { negativamente } \\
\text { Gucy2d } \\
\end{array}$ \\
\hline IMAGE:640144 & FASLG & Gclm & $\mathrm{E} 2 \mathrm{f} 2$ \\
\hline $\mathrm{E} 2 \mathrm{f} 2$ & FASLG & Wdr53 & IMAGE:640272 \\
\hline IMAGE:640272 & CCR7 & Prkdc & IMAGE:583031 \\
\hline HSPD1 & FCRH3 & IMAGE:582951 & IMAGE:640280 \\
\hline IMAGE:583031 & Cnot10 & 2900076A07Rik & IMAGE:640860 \\
\hline Rpl27a & Rnf187 & IMAGE:583456 & Itsn2 \\
\hline IMAGE:640280 & Anxa4 & Atg2b & Hist1h2bc \\
\hline IMAGE:640860 & AI662270 & IMAGE:640598 & Epc1 \\
\hline Itsn2 & Chd9 & $\mathrm{H} 13$ & IMAGE:640351 \\
\hline Hist1h2bc & LOC729230 & IMAGE:640121 & 1110037N09Rik \\
\hline Epc1 & IMAGE:639684 & Eaf1 & Txnrd1 \\
\hline IMAGE:640351 & Hel308 & FASLG & IMAGE:640943 \\
\hline 1110037N09Rik & IMAGE:641087 & FASLG & IMAGE:640817 \\
\hline IMAGE:640451 & Klhl20 & CCR7 & A430107D22Rik \\
\hline Mmp14 & Fos & FCRH3 & Ccdc41 \\
\hline Txnrd1 & IMAGE:583342 & Rnf187 & IMAGE:582879 \\
\hline IMAGE:640943 & IMAGE:1362232 & AI662270 & IMAGE:583053 \\
\hline IMAGE:640817 & Mis12 & Chd9 & E230029C05Rik \\
\hline Gclm & Zmat5 & LOC729230 & IMAGE:640664 \\
\hline Wdr53 & IMAGE:640027 & IMAGE:639684 & IMAGE:640521 \\
\hline IMAGE:640838 & $\mathrm{Cd} 8 \mathrm{a}$ & IMAGE:641087 & $\mathrm{H} 2-\mathrm{K} 1$ \\
\hline Prkdc & Nlk & Klhl20 & Nde1 \\
\hline A430107D22Rik & IMAGE:640717 & IMAGE:1362232 & Nol5a \\
\hline IMAGE:639827 & IMAGE:640843 & IMAGE:640027 & IMAGE:582983 \\
\hline Ccdc41 & IMAGE:583908 & Nlk & IMAGE:640173 \\
\hline IMAGE:582951 & $\operatorname{Arl} 5 \mathrm{c}$ & IMAGE:640717 & Myc \\
\hline IMAGE:582879 & IMAGE:639730 & IMAGE:640843 & IMAGE:641140 \\
\hline 3110037I16Rik & Lef1 & Arl5c & Gabarapl2 \\
\hline IMAGE:640865 & IMAGE:575844 & Lef1 & IMAGE:138013 \\
\hline Dusp2 & D10Ertd610e & D10Ertd610e & Apitd1 \\
\hline Jmjd3 & 2210404O07Rik & 2210404O07Rik & Rab22a \\
\hline IMAGE:583053 & Alg9 & Alg9 & Mrpl34 \\
\hline IMAGE:640837 & IMAGE:576500 & IMAGE:576500 & IMAGE:576044 \\
\hline 2900076A07Rik & 2810021B07Rik & 2810021B07Rik & Maea \\
\hline E230029C05Rik & IMAGE:575208 & IMAGE:575208 & $\mathrm{Cd} 97$ \\
\hline IMAGE:640664 & Sit & Sit & IMAGE:641137 \\
\hline IMAGE:641123 & Sh3gl1 & IMAGE:575254 & Ifngr2 \\
\hline IMAGE:640521 & Cdca8 & IMAGE:576476 & Cnot10 \\
\hline $\mathrm{H} 2-\mathrm{K} 1$ & Gzma & IMAGE:640794 & Anxa4 \\
\hline IMAGE:583456 & IMAGE:575254 & IMAGE:639781 & Hel308 \\
\hline IMAGE:640667 & IMAGE:576476 & IMAGE:640539 & Fos \\
\hline Atg2b & IMAGE:640794 & Stambpl1 & Mis12 \\
\hline
\end{tabular}




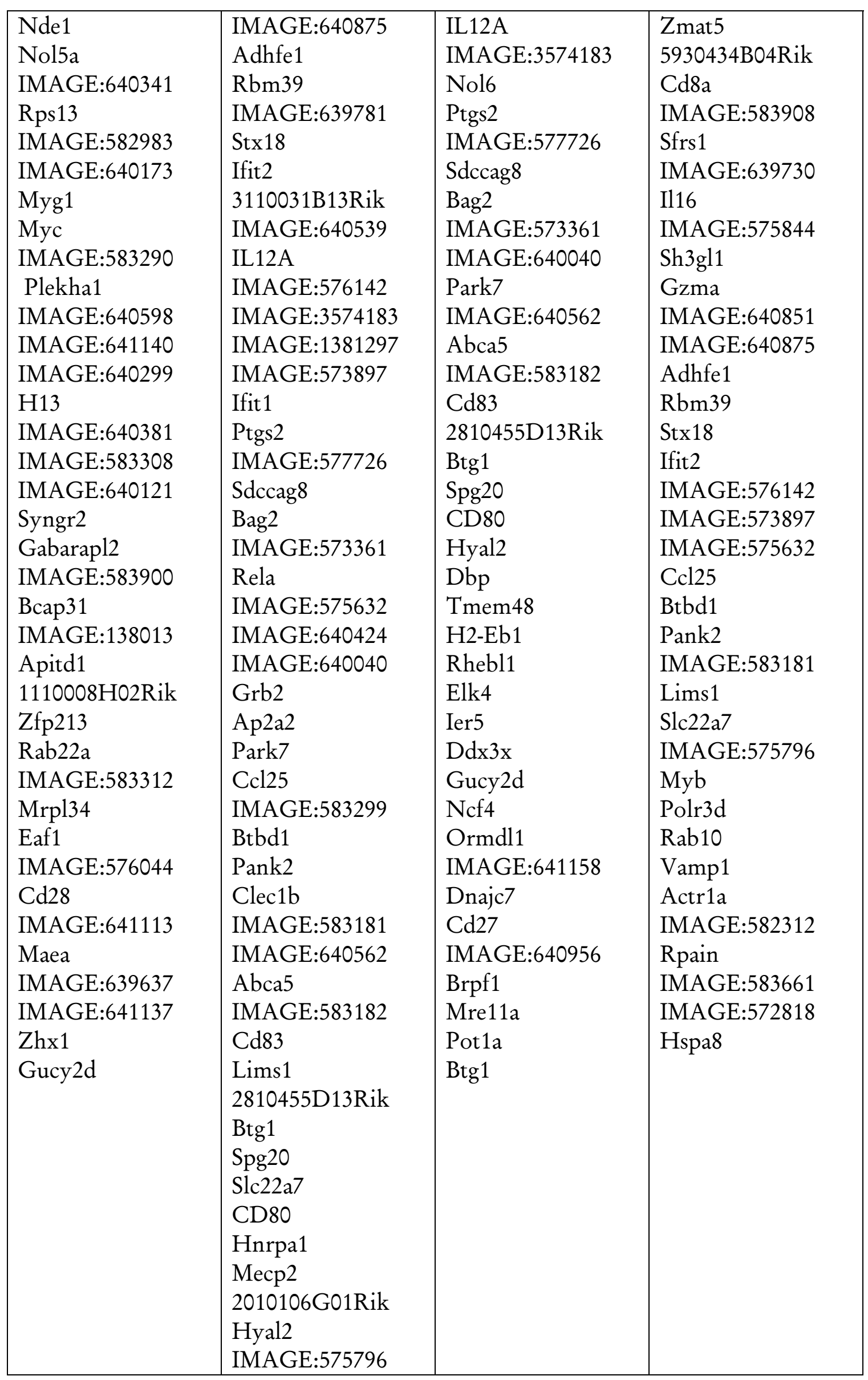




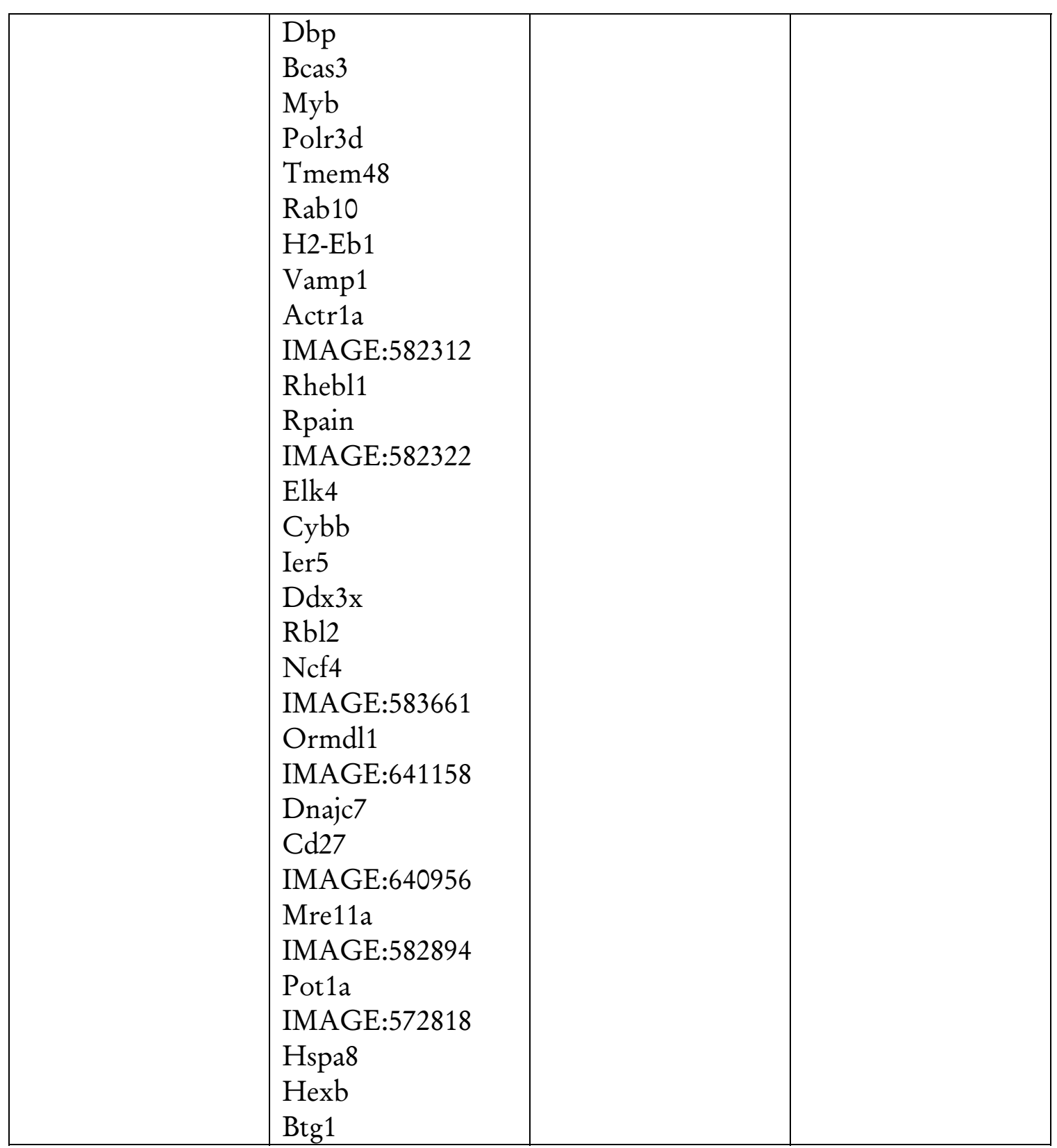


Manuscrito da Tese 
Promiscuous gene expression is connected in network

Promiscuous gene expression in medullary thymic epithelial cells is connected in network where the Aire gene is an upstream modulator

Claudia Macedo ${ }^{1}$, Thaís A. Fornari ${ }^{1}$, Danielle A. R. Magalhães ${ }^{1}$, Cristina M. Junta ${ }^{1}$, Guilherme L. Silva ${ }^{1}$, Leandra L. Linhares ${ }^{2}$, Wilson Savino ${ }^{2}$, Elza T. Sakamoto-Hojo ${ }^{1}$, Eduardo A. Donadi ${ }^{4}$, Geraldo A. S. Passos ${ }^{1,3}$

1) Molecular Immunogenetics Group, Department of Genetics, Faculty of Medicine of Ribeirão Preto, University of São Paulo (USP), Ribeirão Preto, SP, Brazil.

2) Laboratory on Thymus Research, Department of Immunology, Oswaldo Cruz Institute (FIOCRUZ), Rio de Janeiro, RJ, Brazil.

3) Discipline of Genetics, Faculty of Dentistry of Ribeirão Preto, USP, Ribeirão Preto, SP, Brazil.

4) Division of Clinical Immunology, Faculty of Medicine of Ribeirão Preto, University of São Paulo (USP), Ribeirão Preto, SP, Brazil.

Send correspondence to: Dr. Geraldo A. S. Passos

Molecular Immunogenetics Group, Department of Genetics, Faculty of Medicine of Ribeirão Preto, University of São Paulo (USP), Via Bandeirantes, 3900 ZIP CODE: 14040-900, Ribeirão Preto, SP, Brazil.

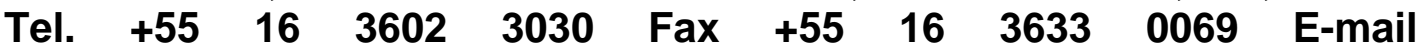
passos@rge.fmrp.usp.br 


\section{Abstract}

The expression of peripheral tissue antigens (PTAs) in the thymus by medullary thymic epithelial cells (mTECs) is essential for the central selftolerance of $T$ cells. Due to heterogeneity of autoantigen representation this phenomenon has been termed promiscuous gene expression (PGE), in which the autoimmune regulator (Aire) gene plays a role as main transcriptional activator on a large set of Aire-dependent PTAs. Aire protein is able in binding to specific DNA sequence motifs and plays a role as a direct regulator. Here we used the cDNA microarray method to access PGE in murine $\mathrm{CD}^{+} 0^{+} 3.10 \mathrm{mTEC}$ cell strain cultured in vitro. Hierarchical clustering of the data allowed observation that PTA genes were differentially expressed being possible to found those induced or repressed. To further investigate the control of PGE, we hypothesize that PTA genes establish networks, reflecting the existence of a feedback-like control of the transcriptional levels. Aire in this case plays a role as upstream modulator. To test this hypothesis, initially we silenced Aire by gene knockdown (RNA interference) in 3.10 mTEC cells. Hierarchical clustering of cDNA microarray data showed a set of Aire-dependent PTA genes, which were downregulated after Aire silencing. Gene networks reconstructed from these data allowed the identification of a gene node (Gucy2d) establishing positive regulation upon downstream genes in normal mTECs. Nevertheless, under silencing of Aire, Gucy2d has become a repressor on PTA genes. These findings evidentiate that genes featured in PGE are connected in network, a gene node may act as intermediate in their control and that Aire in PGE network plays a role as an upstream regulator. 


\section{Introduction}

Self-tolerance of the T cell repertoire is acquired during the development of immature $\mathrm{T}$ cells, a phenomenon dependent on the avidity of the interaction between specific $\mathrm{T}$ cell receptor (TCR) and self-peptide-MHC ligands. The nascent $\mathrm{T}$ cell repertoire in the thymus determines the diversity of self-antigens and the specificity of central-tolerance. We agree with Kyewski and Derbinski (2004) in subsuming under central tolerance the intrathymic mechanisms, which $\mathrm{T}$ cells undergo in recognition of selfantigens. Accordingly, self-reactive regulatory $T\left(T_{\text {reg }}\right)$ cells are selected in the thymus, even though these cells play their role in the periphery.

In fact, all subsets of antigen-presenting cells (APCs), such as cortical thymic epithelial cells (cTECs), medullary thymic epithelial cells (mTECs), thymic dendritic cells and macrophages play their roles in presenting unique sets of self-peptides, contributing to the diversity of self-antigens displayed in the thymus (Klein and Kyewski 2000; Anderson et al., 2007).

However, the expression of PTAs in the thymus, which represents a key feature for effecting self-representation, was only recently recognized in the immunologic research. The evidence of thymic expression of PTAs in mice and humans, which has been referred to as promiscuous gene expression (PGE) (Jolicoeur et al., 1994; Derbinski et al., 2001; Gotter et al., 2004), reinforced the conception of central tolerance of tissue-restricted selfantigens.

Prior to this evidence, the peripheral tolerance, that is, the mechanisms by which $\mathrm{T}$ cell selection towards PTAs occurs outside the thymus, 
dominated the scenario in explaining self-non-self discrimination (Alferink et al., 1999; Walkerand Abbas 2002).

Promiscuous gene expression in the thymus is causing a reversal in the scope of central tolerance understanding, allowing for an unorthodox conception of the possible mechanisms of self-non-self discrimination (Kyewsky et al., 2002, Gallegos and Bevan, 2006; Magalhães et al., 2006; Sousa Cardoso et al., 2006).

The main implication of this heterogeneous gene expression in the thymus is associated with the maintenance of the immunological homeostasis in the body, controlling the pathogenic autoimmune reactions.

Evidence for this phenomenon was obtained using the reverse transcription-PCR (RT-PCR) method, which was biased towards antigens in autoimmune reactions, such as insulin, acetylcholine receptor or myelin basic protein. Today it is recognized that rather than selective, the set of expressed genes is as broad as possible, and involves up to $5-10 \%$ of the all known mouse genes (Derbinski et al., 2001; Gotter et al., 2004; Kyewski and Derbinski, 2004).

The extent of self-representation of most parenchymal tissues and organs is guaranteed by PGE in the thymus, a phenomenon exhibited by mTECs. Accordingly, the complexity of PGE increases in ascending order, from cortical thymic epithelial cells (cTECs) to immature mTECs to mature CD80+ mTECs. These different gene pools are not complementary but additive, that is, there is no apparent association between the respective molecular/biological function of the genes in parenchymal organs. The significance of PGE in the thymus is associated with central tolerance of $T$ 
cells (Sospedra et al., 1998; Bruno et al., 2002; Kyewski and Derbinski, 2004). While PGE was well characterized in mTECs by the authors above cited and in intact thymus by our group (Sousa Cardoso et al., 2006; Magalhães et al., 2006), their detailed molecular control requires further exploration.

A gene identified and cloned in 1997 was termed AIRE (autoimmune regulator) due to their association with autoimmune polyendocrinopathycandidiasis ectodermal dystrophy (APECED) syndrome, a human autoimmune disease, (Finnish-German APECED Consortium, 1997; Nagamine et al., 1997). Studies in mice have permitted an extensive mechanistic dissection of how Aire operates. It was found that Aire is expressed primarily in lymphoid organs, especially the thymus. Within the thymus it is expressed mostly by medullary epithelial cells (MECs) strongly by mTECs but also although at much lower levels, by dendritic cells (Anderson et al., 2002; Anderson et al., 2005).

Identifying Aire expression in MECs was intriguing because of suggestions that this cell-type is involved in the negative selection of selfreactive thymocytes (Kishimoto and Sprent, 1997) and because of the coincident emergence of data establishing that transcripts encoding PTAs are ectopically expressed specifically by MECs (Kyewski and Klein, 2006).

These evidences allowed the formulation the hypothesis that Aire regulates the thymic transcription of PTA genes and thus thymocyte tolerization and therefore autoimmune reactions.

The Aire-knockout mice harbored a normal immune system but featured multi-organ autoimmunity, as indicated by both inflammatory infiltrates and 
serum autoantibodies, allowing confirming this hypothesis (Anderson et al., 2002; Ramsey et al., 2002; Kuroda et al., 2005).

Expression profiling of MECs isolated from Aire-knockout mice allowed the identification of autoantigen-encoding genes, such as insulin, salivary protein-1 and fatty-acid-binding protein, which are under its control (Anderson et al., 2002, 2005). Meanwhile, other PTA genes, such as Creactive protein and glutamic acid decarboxilase of $67 \mathrm{kDa}$ (GAD67), appeared to be independent of Aire expression (Derbinski et al., 2005). Aire also regulates the transcription of genes that do not encode PTAs.

As discussed by Mathis and Benoist (2007), a broad question still remain to be clarified on the molecular mechanisms underlying the function of Aire, that is, precisely how the protein coded by this gene promotes ectopic transcription of genes encoding PTAs and certain other proteins while repressing other loci.

Bioinformatic re-evaluations have shown that Aire transcription might influence a large number of genes, in the order of thousands rather than hundreds, representing a significant fraction of the genome (Derbinski et al., 2005).

Aire has many features of a transcription factor, sharing several domains with known transcriptional control elements (Bottomley et al., 2001; Isaac et al., 2006) and can also associate with other transcription factors, such as CERB-binding protein (CBP), at least in vitro (Pitkanen et al., 2000, 2005).

Other several characteristics of AIRE distinguish it from a "conventional" transcription factor that binds to a well defined DNA motif in an enhancer or promoter regions of a co-ordinately regulated genes. Certainly the effect of 
AIRE on ectopic PTA gene expression is not that of a simple on/off operon; its effect on most genes is only partial, and a number of PTAs are not affected by AIRE (Mathis and Benoist, 2007).

In addition the wideness of its transcriptional impact weaken the notion of a classical site-specific control element, as it is not easy to envision that AIRE-binding site occurs in thousands of promoters of such disparate structure (Mathis and Benoist, 2007).

These considerations may suggest an indirect mode of action for Aire. Here, we hypothesize that PTA genes in mTECs establish networks, reflecting the existence of a feedback-like control of the transcriptional levels. Aire in this case plays a role as upstream modulator.

\section{Material and Methods}

Medullary thymic epithelial cell line

Medullary 3.10 TEC line was kindly provided by Willem van Ewijk (Rotherdam University, The Netherlands) to one of us (W.S.). This cell line was established from C57BL/6 mice and medullary phenotype was determined by immunostaining with Th- 4 antibody. They was further evaluated in one of our laboratory (W. Savino) using a panel of anticytokeratin monoclonal antibodies, which confirmed the original distinct medullary phenotype. Cells were cultured in $10 \%$ fetal bovine serumsupplemented RPMI 1640 medium at $37^{\circ} \mathrm{C}$ in a $5 \% \mathrm{CO}_{2}$ atmosphere.

\section{Silencing Aire gene transcript}

We used the TriFecta ${ }^{\text {TM }}$ (IDT, Integrated DNA Technologies, USA) antiAire SiRNA sequence (GGAUUCUCUUUAAGGACUACAAUCTAGAUUGUAGUCCUUAAAGAGAA UCCUC) to silencing Aire mRNA. Confluent cultures of 3.10 mTEC cell line 
were transfected with $10 \mathrm{nM}$ of anti-Aire siRNA using Hiperfect reagent (Qiagen) following manufacturer's instructions.

After transfection, cells were cultured during $24 \mathrm{~h}$ in RPMI medium as above mentioned and total RNA was extracted using the mirVana kit (Ambion), which served as template for cDNA synthesis. Gene knockdown was confirmed by semi-quantitative reverse transcription PCR (RT-PCR) using the primers 5' CATCCTGGATTTCTGGAGGA 3' forward and 5' GCTCTTTGAGGCCAGAGTTG 3' reverse, which allowed amplification of a 253 bp PCR product corresponding to a segment of the Aire mRNA (cDNA). The PCR mix contained 200 uM dNTPs, $1.5 \mathrm{mM} \mathrm{MgCl}_{2}, 50 \mathrm{mM} \mathrm{KCl}, 10 \mathrm{mM}$ TRIS-HCl (pH 8.4), $10 \mathrm{uM}$ each primer and $2 \mathrm{U}$ Taq DNA polymerase. The cycling temperature was: $35 \times 30 \mathrm{sec}$ each $\left(94^{\circ} \mathrm{C}, 57^{\circ} \mathrm{C}\right.$ and $\left.72^{\circ} \mathrm{C}\right)$.

An anti-HPRT siRNA included in this kit but whose sequence was not furnished was used in parallel to evaluate the efficiency of the gene knockdown assay on 3.10 mTEC cell line (data not shown).

cDNA microarray

The gene expression of 3.10 mTEC cell line was assessed using glass slide cDNA microarrays prepared on silane-coated UltraGAPS slides (\# 40015, Corning $\AA$, New York, NY, USA) containing a total of 4,500 target tissue restricted antigen cDNA sequences representing most of murine tissue and organs. These were from the Soares thymus $2 \mathrm{NbMT}$ normalized library, representing expressed sequence tag (ESTs) cDNA clones prepared from the thymus of a C57BL/6J 4-week-old male mouse, and available at the IMAGE Consortium (http://image.Ilnl.gov/image/html/iresources.shtml). The cDNA inserts were homogeneous in size (near $1 \mathrm{~kb}$ ), cloned in three vectors (pT7T3D, 
pBluescript and Lafmid) and were amplified in 384- or 96-well plates using vector-PCR amplification with the following primers, which recognize the three vectors: LBP 1S GTGGAATTGTGAGCGGATACC forward and LBP 1AS GCAAGGCGATTAAGTTGG reverse.

The microarrays were prepared based on published protocols using PCR products from the cDNA clones [Hedge et al., 2000] using a Generation III Array Spotter (Amersham Molecular Dynamics, Sunnyvale, CA, USA). A complete file providing all genes and ESTs present in the microarrays used in this study is available on line at (www.rge.fmrp.usp.br/passos/mmu_array)

\section{Complex cDNA probe preparation and hybridization}

The cDNA complex probes derived from total RNA obtained of control or Aire silenced 3.10 mTECs were prepared by reverse transcription using $10 \mu \mathrm{g}$ of total RNA. For this study, we opted for monocolor labeling and then the cDNA samples were labeled with Cy3 fluorochrome using the CyScribe post labeling kit (GE Healthcare Biosciences). The 15 hour period required for hybridization was allowed to elapse, followed by washing, using an automatic slide processor system (ASP, Amersham Biosciences) and microarrays were scanned using a Generation III laser scanner (Amersham Biosciences).

As a reference for the hybridization procedure, we used equimolar quantities of cDNAs obtained from unrelated total RNA (mouse thymus total RNA). This approach allowed estimation of the amount of cDNA target in each microarray spot.

cDNA microarray data analysis

The microarray image quantification was performed using the Spotfinder software (http://www.tm4.org/spotfinder.html). The normalization process was carried out using the R platform (http://www.r-project.org) and statistical data 
were analyzed using the Multiexperiment Viewer (MeV) software (version 3.1; available online at (http://www.tm4.org/mev.html) [Smyth, 2004].

The differentially expressed genes (induced or repressed) between control and Aire silenced mTECs were identified by using the significance analysis of microarrays program (SAM) (Tusher et al., 2001) considering only those genes presenting both FDR (false discovery rate) and $p$ value $\leq 0.01$.

To analyze the gene expression profiling we used an unsupervised hierarchical clustering method that grouped genes on the vertical axis and samples on the horizontal axis, on the basis of similarity in their expression patterns. The similarities and dissimilarities in gene expression are presented as dendrograms, in which the pattern and length of the branches reflect the relatedness of the samples or genes, and as heat maps (Eisen et al., 1989) (Cluster version 3.0 and Java Tree View (http://rana.Ibl.gov/EisenSoftware.htm).

\section{Determination of PGE in mTECs}

PGE was identified on the basis of data from microarray analysis of the different mouse organs using combined information from the public database GNF Gene expression Atlas (http://symatlas.gnf.org/SymAtlas). This data bank shows gene expression in more than 60 mouse tissue/organs, as assessed by gene array analysis using Affymetrix microarrays. Data information includes GenBank accession, chromosomal location, tissue/organ representation and molecular/biological function of each gene analyzed.

In this study, only the promiscuous genes of which the expression was detected in different organs or tissues and of which the expression levels were greater than median in relation to all other organs which appear in the GNF Atlas were considered. The modulation of transcription levels (repression or 
induction) of these genes was evaluated comparing control and Aire silenced 3.10 mTECs.

\section{Reconstruction of gene networks}

The GeneNetwork 1.2 algorithm [Wu et al., 2004] was used to compare means of different gene expression values whose standard deviation did not overlap, whose objective was to compute a network that established relationships between all genes. The linear interpolation for the network organization was used. The software for this algorithm can be obtained from the authors (http://idv.sinica.edu.tw/hchuang/GeneNetwork1.2Setup.exe).

In order to organize networks only with genes whose expression values were significant, values for the induced and repressed genes selected by the SAM statistics were used. In this case, of the 4,500 sequences present on the microarray, a total of 212 from control and 212 from Aire silenced 3.10 mTECs differentially expressed genes were included in the calculations of the GeneNetwork software due to their statistical significance.

\section{Results and Discussion}

PGE exhibited by mTECs in the thymus is a complex phenomenon until now observed in humans and mice and involves $5-10 \%$ of all known genes of these species. This process is a guarantee of self-representation of most parenchymal tissues and organs during the central tolerance of T cells.

Using RT-PCR, some of the most important autoantigens mRNAs, such as thyroglobulin, CRP, GAD67, insulin and albumin were detectable only in mTECs 
purified from ex vivo mouse thymic tissue at embryonic day 15 (E15) (Derbinski et al., 2001).

In view of that, the complexity of PGE increases in, from cTECs to immature mTECs to mature CD80 hi mTECs. As the PGE is a phenomenon associated to autoantigen representation, the different gene pools are not complementary, but additive, that is, there is no apparent association between the molecular/biological functions of the genes representing parenchymal organs and tissues. The significance of PGE in the thymus is related with the central tolerance to self antigens (Kyewski and Derbinski, 2004; Sospedra et al., 1998; Bruno et al., 2002; Bruno et al., 2004; Derbinski et al., 2005; Gallegos et al., 2006).

In a recent study made by our group and using RT-PCR, we observed that the Aire gene start its expression in embryonic mouse thymus at E16 stage and by cDNA microarray method, it was observed that PGE emerges as high throughput gene expression at E20 stage (Sousa Cardoso et al., 2006).

PGE is today a well documented phenomenon, but several of their aspects are still unexplored, as for example, its evaluation in the thymus of autoimmune and/or knockout mouse strains, its modulation by means of cytokines or other molecules interfering in the gene expression, such as RNA interference.

In the present study, we used a purified $\mathrm{CD} 80^{+}$mature mTEC cell line growing in vitro to further explore the role of the Aire gene in the control of PGE.

Initially we demonstrated by RT-PCR that the 3.10 mTEC cell line expresses Aire gene corroborating previous data from the literature (Figure 1).

We were able in the silencing this gene by RNA interference (RNAi) (Figure 2), which although partial, allowed to evidentiate the PTA genes, which were 
down regulated in $\mathrm{mTEC}$ cells. Figure 3 shows the gene expression hierarchical clustering of statistically significant (SAM program) microarray data of control and Aire-silenced mTEC cells. It was possible to evidentiate 212 differentially expressed PTA genes, which 135 were induced in control mTECs and repressed after Aire silencing.

This gene data set was compared with GNF database allowing picturing the PGE featured by mTECs following the effect of Aire silencing. The PTA genes were grouped in 17 body systems, which are represented in this mTEC cell line (Figure 4). It was possible to found that these 135 PTA genes are under control of the Aire gene, since its silencing caused their repression.

Nevertheless, still remained the question about if the genes, which feature PGE are connected in networks and what is the role of the Aire gene in their control.

Two widely used methods for microarray data analysis are the Cluster-andTree View (Eisen et al., 1989), which is based on a mathematical description of similarity and the organization of gene expression data is realized by grouping together genes with similar patterns of expression (hierarchical clustering), and the Significance Analysis of Microarray (SAM) (Tusher et al., 2001), which is based on $t$ test statistics specifically developed for high-throughput microarray data.

Although these methods are useful tools for the identification of differentially expressed genes, they not permit the determination of interactions between genes.

There are several computational solutions proposed in the literature to infer gene networks; the approaches based on the mathematical formalism of the 
information theory as ARACNE program (Basso et al., 2005; Margolin et al., 2006), the algorithms that consider ordinary differential equations as NIR, NMI and TSNI programs (Gardner et al., 2003; Di Bernardo et al., 2005; Bansal et al., 2006) and those which solve the inference problem by means of Bayesian networks as Banjo (Yu et al., 2004) and GeneNetwork (Wu et al., 2004) programs.

Comparing the algorithms, GeneNetwork was chosen for the analysis purposes due to its differential features. The algorithm realizes the interpolation of data and is able to handle with more than one thousand of genes. Moreover, the resulting network is described by an oriented graph in which positive arrows indicate induction and negative ones denote repression between genes.

In an effort to provide a clearer understanding of the high-throughput data resulting from microarray experiments and to establish regulatory interactions in PGE, normalized data were analyzed by the GeneNetwork program (Wu et al., 2004), which is based on dynamic Bayesian statistics inferring gene networks.

Figure 5a shows that PTA genes featuring PGE in mTECs are in fact connected in network. It was found that the Gucy2d (guanylate cyclase 2d) gene, which was induced in control mTECs, plays a role as a gene node due to its numerous interactions, mostly as a positive controller, established among other genes.

Silencing Aire in mTECs, the Gucy2d gene was subsequently repressed but still played a role as a gene node, which instead positive turned a negative controller, repressing mostly of PTA genes (Figure $5 b$ ).

These findings are important firstly to evidentiate that PTA genes in mTECs are connected in network, which might reflect the existence of a feedback-like 
control of their transcriptional levels, secondly that a gene, such as Gucy2d, may act as additional positive controller upon downstream genes besides Aire in the control of PGE.

\section{Acknowledgements}

This study received financial support from Fundação de Amparo à Pesquisa do Estado de São Paulo (FAPESP grant No. 06/54788-4) and Conselho Nacional de Desenvolvimento Científico e Tecnológico (CNPq). We thank Dr. Catherine Nguyen of the Institut National de la Santé et de la Recherche Médicale (INSERM) of Marseille, France for the cDNA clones used in the preparation of the microarrays.

\section{References}

Kyewski B, Derbinski J (2004). Self-representation in the thymus: an extended view. Nat Rev Immunol 4, 688-698.

Klein L, Kyewski B (2000). Self-antigen presentation by thymic stromal cells: a subtle division of labor. Curr Opin Immunol. 12(2):179-86.

Anderson G, Lane PJL, Jenkinson EJ (2007). Generating intrathymic microenvironments to establish T-cell tolerance. Nat. Rev. Immunol. 7(12): 954-63.

Jolicoeur C, Hanahan D, Smith KM (1994). T-cell tolerance toward a transgenic $\beta$-cell antigen and transcription of endogenous pancreatic genes in thymus. Proc. Natl Acad. Sci. USA 91, 6707-6711.

Derbinski J, Schulte A, Kyewski B, Klein L (2001). Promiscuous gene expression in medullary thymic epithelial cells mirrors the peripheral self. Nature Immunology 2: 1032-1039.

Gotter J, Brors B, Hergenhahn M, Kyewski B (2004). Medullary epithelial cells of the human thymus express a highly diverse selection of tissue-specific genes co-localized in chromosomal clusters. J. Exp. Med. 199(2): 155166.

Alferink J, Aigner S, Reibke R, Hämmerling GJ, Arnold B (1999). Peripheral T cell tolerance: the contribution of permissive $\mathrm{T}$ cell migration into parenchymal tissues of the neonate. Immunol. Rev. 169, 255-261.

Walker LS, Abbas AK (2002). The enemy within: keeping self-reactive T cells at bay in the periphery. Nature Rev. Immunol. 2, 11-19. 
Kyewski B, Derbinski J, Gotter J, Klein L (2002). Promiscuous gene expression and central T-cell tolerance : more than meets the eye. Trends Immunol. 23: 364

Gallegos AM, Bevan MJ (2006). Central tolerance: good but imperfect. Immunol Rev. 209: 290-6.

Magalhães DA, Silveira EL, Junta CM, Sandrin-Garcia P, Fachin AL, Donadi EA, Sakamoto-Hojo ET, Passos GA (2006). Promiscuous gene expression in the thymus: the root of central tolerance. Clin Dev Immunol.13(2-4):8199.

Sousa Cardoso R, Magalhães DAR, Baião AMT, Junta CM, Macedo C, Marques MMC, Sakamoto-Hojo ET, Donadi EA, Passos GAS (2006). Onset of promiscuous gene expression in murine fetal organ culture. Immunology 119: 369-375.

Sospedra M, Ferrer-Francesch X, Dominguez O, Juan M, Foz-Sala M, PujolBorrel R. (1998) Transcription of broad range of self-antigens in human thymus suggests a role for central mechanisms in tolerance toward peripheral antigens. J. Immunol. $161: 5918$

Bruno R, Sabater L, Sospedra M, Ferrer-Francesch X, Escudero D, Martı'nezCa'ceres E, Pujol-Borrel R. Multiple sclerosis candidate autoantigens except myelin oligodendrocyte glycoprotein are transcribed in the human thymus. Eur J Immunol 2002; 32:2737-47.

Finnish-German APECED Consortium (1997). An autoimmune disease, APECED, caused by mutations in a novel gene featuring two PHD-type zinc-finger domains. Nature Genetics 17, 399-403.

Nagamine K, Peterson P, Scott HS, Kudoh J, Minoshima S, Heino M, Krohn KJ, Lalioti MD, Mullis PE, Antonarakis SE, Kawasaki K, Asakawa S, Ito F, Shimizu N (1997). Positional cloning of the APECED gene. Nature Genetics 17: 393-398.

Anderson MS, Venanzi ES, Klein L, Chen Z, Berzins SP, Turley SJ, von Boehmer H, Bronson R, Dierich A, Benoist C, Mathis D (2002). Projection of an immunological self-shadow within the thymus by aire protein. Science 298: 1395.

Anderson MS, Venanzi ES, Chen Z, Berzins SP, Benoist C, Mathis D (2005). The NOD mouse: a model of immune dysregulation. Annu. Rev. Immunol. 23: 447.

Kishimoto H, Sprent J (1997). Negative selection in the thymus includes semimature T cells. J. Exp. Med. 185: 263-271.

Kyewski B, Klein L (2006). A central role for central tolerance. Annu. Rev. Immunol. 24: 571-606.

Ramsey C, Winqvist O, Puhakka L, Halonen M, Moro A, Kämpe O, Eskelin P, Pelto-Huikko M, Peltonen L (2002). Aire deficient mice develop multiple features of APECED phenotype and show altered immune response. Hum. Mol. Genet. 11, 397409.

Kuroda N, Mitani T, Takeda N, Ishimaru N, Arakaki R, Hayashi Y, Bando Y, Izumi K, Takahashi T, Nomura T, Sakaguchi S, Ueno T, Takahama Y, 
Uchida D, Sun S, Kajiura F, Mouri Y, Han H, Matsushima A, Yamada G, Matsumoto M (2005). Development of autoimmunity against transcriptionally unrepressed target antigen in the thymus of Aire-deficient mice. J. Immunol. 174, 18621870 (2005).

Derbinski J, Gäbler J, Brors B, Tierling S, Jonnakuty S, Hergenhahn M, Peltonen L, Walter J, Kyewski B (2005). Promiscuous gene expression in thymic epithelial cells is regulated at multiple levels. J. Exp. Med. 202(1): 33-45.

Mathis D \& Benoist C (2007) A decade of AIRE. Nat Rev Immunol. 7(8):64550.

Bottomley MJ, Collard MW, Huggenvik JI, Liu Z, Gibson TJ, Sattler M. (2001). The SAND domain structure defines a novel DNA-binding fold in transcriptional regulation. Nat Struct Biol. 8(7):626-33.

Isaac A, Wilcox KW, Taylor JL. (2006). SP100B, a repressor of gene expression preferentially binds to DNA with unmethylated CpGs. J Cell Biochem. 98(5):1106-22.

Pitkanen J, Doucas V, Sternsdorf T, Nakajima T, Aratani S, Jensen K, Will H, Vähämurto $P$, Ollila J, Vihinen $M$, Scott HS, Antonarakis SE, Kudoh J, Shimizu N, Krohn K, Peterson P (2000). The autoimmune regulator protein has transcriptional transactivating properties and interacts with the common coactivator CREB-binding protein. J Biol Chem. 275(22):168029.

Pitkänen J, Rebane A, Rowell J, Murumägi A, Ströbel $P$, Möll K, Saare M, Heikkilä J, Doucas V, Marx A, Peterson P (2005). Cooperative activation of transcription by autoimmune regulator AIRE and CBP. Biochem Biophys Res Commun. 333(3):944-53.

Hedge P, Qi R, Abernathyk, Gay C, Dharap S, Gaspard R, Eaele-Hugues J, Snesrud E, Lee N, Quackenbush J (2000). A concise guide to cDNA microarray analysis. Biotechniques. 29(3):548-562.

Smyth GK (2004). Linear models and empirical Bayes methods for assessing differential expression in microarray experiments. Stat. Appl. Genet. Mol. Biol. 3.

Tusher VG, Tibshirani R, Chu G (2001). Significance analysis of microarrays applied to the ionizing radiation response. Proc. Natl. Acad. Sci, USA 98 (9): 5116-5121.

Eisen, M. B., Spellman, P. T., Brown, P. O., and Botstein, D. (1998). Cluster analysis and display of genome-wide expression patterns. Proc. Natl. Acad. Sci. USA 95, 14863-14868.

Wu CC, Huang HC, Juan HF, Chen, ST (2004). GeneNetwork: an interactive tool for reconstruction of genetic networks using microarray data. Bioinformatics 20(18): 3691-3.

Derbinski J, Schulte A, Kyewski B, Klein L (2001). Promiscuous gene expression in medullary thymic epithelial cells mirrors the peripheral self. Nature Immunology 2: 1032-1039. 
Bruno R, Sabater L, Tolosa E, et al. Different patterns of nicotinic acetylcholine receptor subunit transcription in human thymus. J Neuroimmunol 2004; 149:147-59.

Gallegos AM, Bevan MJ (2006). Central tolerance: good but imperfect. Immunol Rev. 209: 290-6.

Basso K, Margolin AA, Stolovitzky G, Klein U, Dalla-Favera R, Califano A (2005) Reverse engineering of regulatory networks in human B cells. Nat Genet 37: 382-390

Margolin A, Nemenman I, Basso K, Wiggins C, Stolovitzky G, Della Favera R, Califano A (2006) Aracne: an algorithm for the reconstruction of gene regulatory networks in a mammalian cellular context. BMC Bioinformatics S1

Gardner T, di Bernardo D, Lorenz D, Collins J (2003) Infering genetic networks and identifying compound mode of action via expression profiling. Science 301: 102-105

Di Bernardo D, Thomson M, Gardner T, Chobot S, Eastwood E, Wojtovich A, Elliott S, Schaus S, Collins J (2005) Chemogenomic profiling on a genome-wide scale using reverse-engineered gene networks. Nat. Biotechnol. 23; 377-383

Bansal M, Della Gatta G, di Bernardo D (2006) Inference of gene regulatory networks and compound mode of action from time course gene expression profiles. Bioinformatics 22: 815-822

Yu J, Smith VA, Wang PP, Hartemink AJ, Jarvis ED (2004) Advances to Bayesian network inference for generating causal networks from observational biological data. Bioinformatics 20: 3594-3603 
Figures

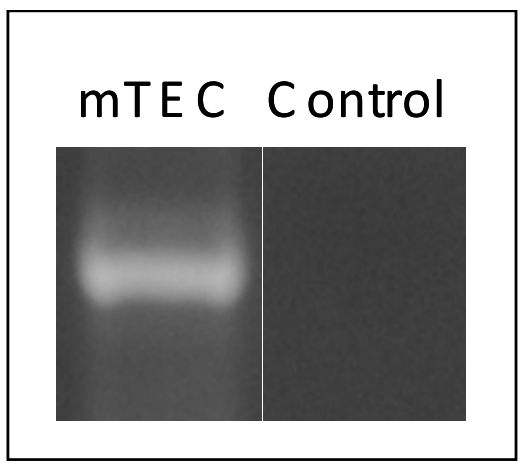

Figure 1. rt-PCR to Aire gene in mTEC 3.10 cells and the negative control.

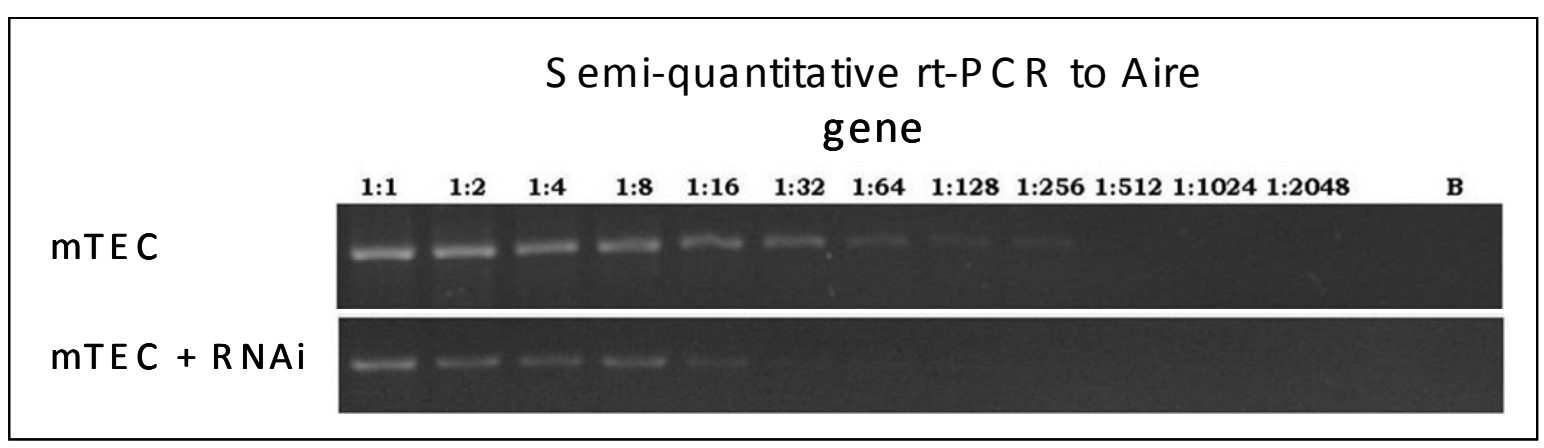

Figure 2. Semi-quantitative rt-PCR to Aire gene. 


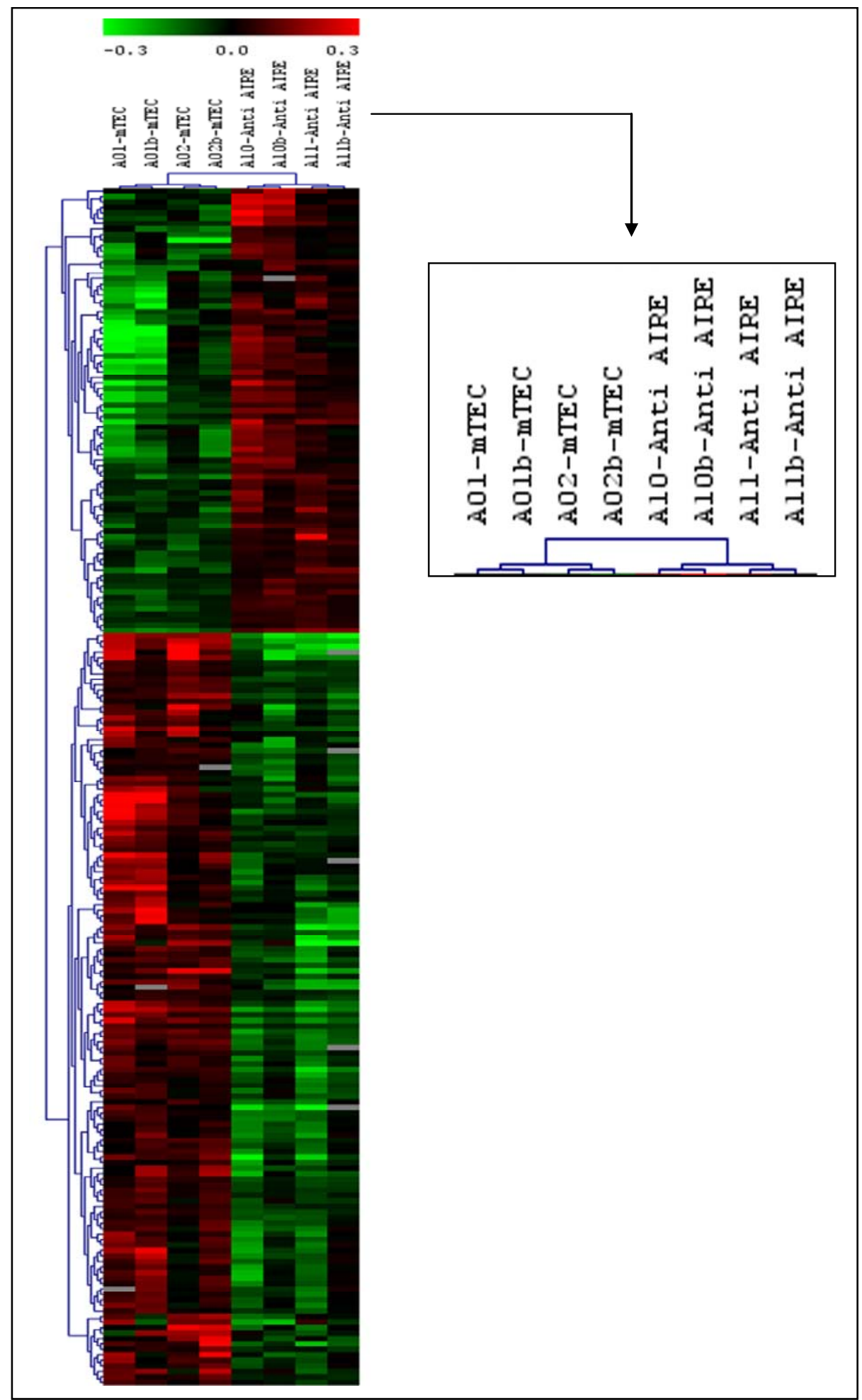

Figure 3. The gene expression hierarchical clustering of statistically significant (SAM program) microarray data of control and Aire-silenced mTEC cells. The clustering was performed using Pearson correlation and average linkage, in TIGR MEV program (http://www.tm4.org/mev.html). 


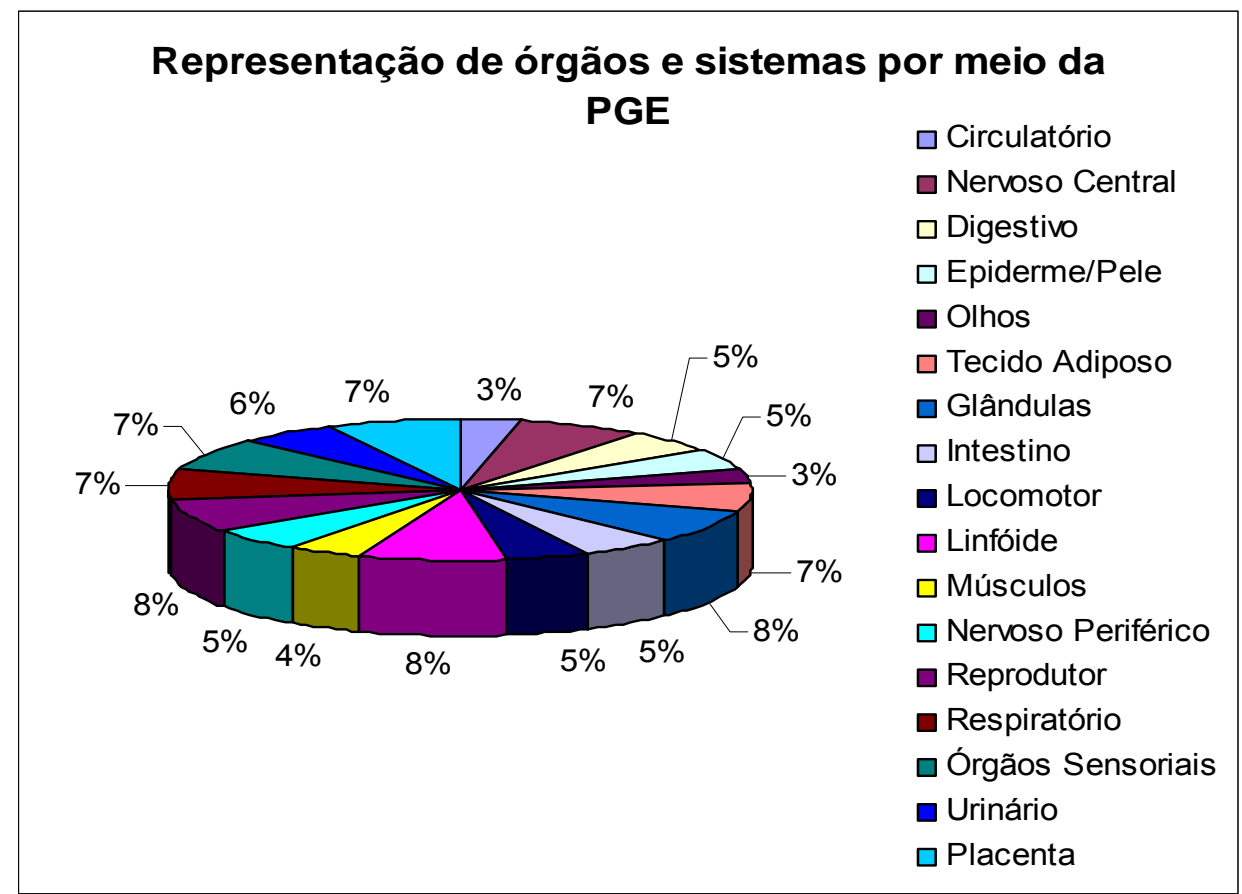

Figure 4. The 17 systems and its representation in mTEC cells. 


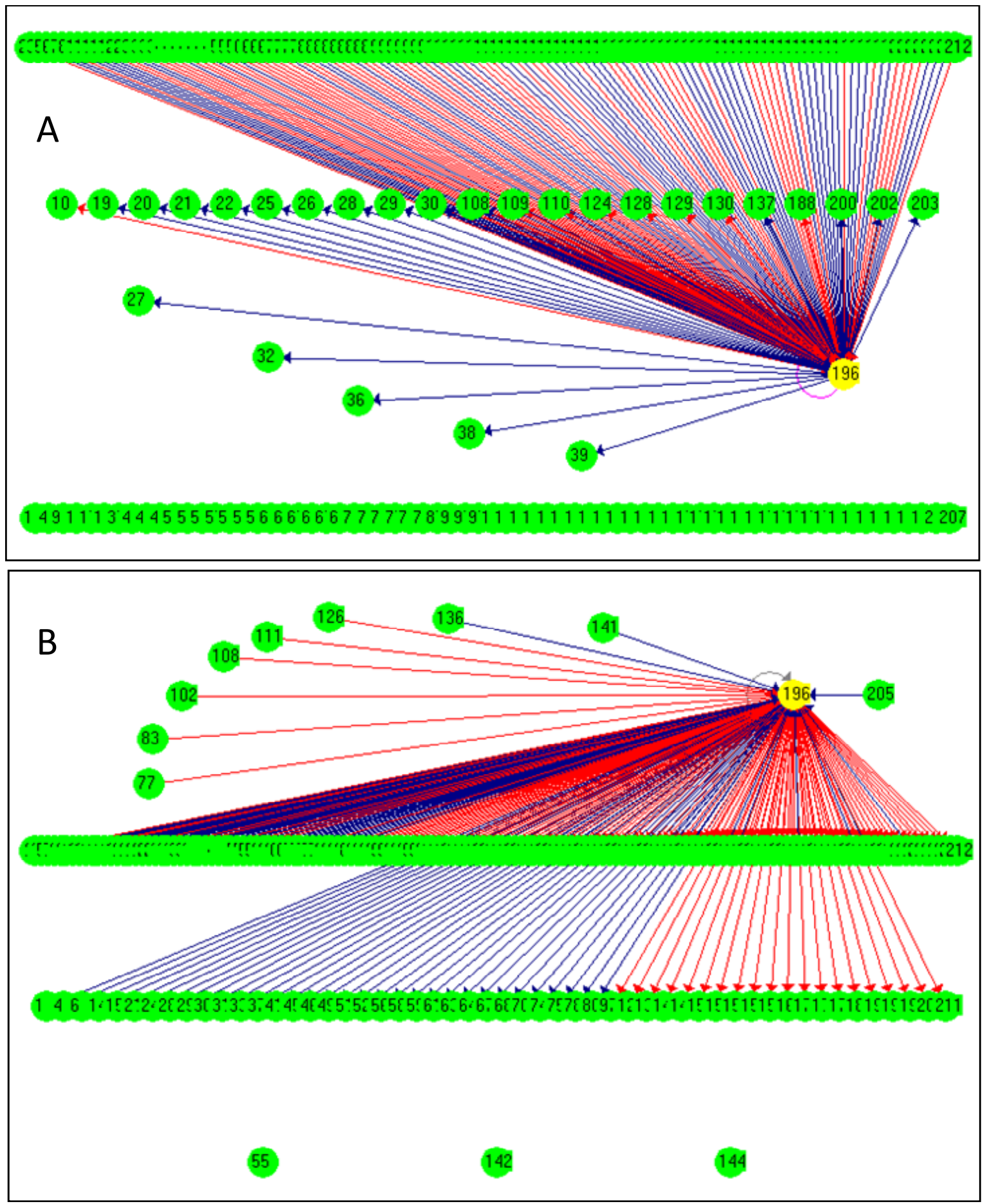

Figure 5. Genetics networks for medullary thymic epithelial cells (mTEC 3.10 cell line). A) control mTECs cells B) mTECs cells following the effect of Aire silencing. 
Súmula Curricular 


\section{CURRICULUM VITAE (Janeiro 2008)}

Claudia Macedo

Bióloga

E-mail: macedo@rge.fmrp.usp.usp.br

\section{DADOS PESSOAIS:}

Nome: Claudia Macedo

Endereço: Rua Tim Lopes, 502 - Ribeirão Verde.

Ribeirão Preto-SP CEP: 14079-190

Fone: (16) 3996-1710/9204-0602

Filiação: Jamil José Macedo e Iracy Marçal de Jesus Macedo

Nacionalidade: Brasileira

Data de Nascimento: 03/08/1976 São Paulo-SP, Brasil.

Estado Civil: casada

\section{DADOS DE IDENTIFICAÇÃO:}

Carteira de identidade: 28.121.173-5, SSPSP - 21/01/1992

Cadastramento de pessoa física: 265.974.628-24

Título de eleitor: 264371570175

\section{FUNÇÃO ATUAL}

Doutorado: Departamento de Genética, Faculdade de Medicina de Ribeirão Preto-USP, Campus de Ribeirão Preto, com bolsa de pesquisa CNPq. Área de concentração: Genética.

\section{ESCOLARIDADE}

$\checkmark$ Doutor em Ciências (em andamento) pela Faculdade de Medicina de Ribeirão Preto. Área de concentração Genética: sub-área: Imunogenética Molecular - Projeto de Tese: O papel modulador do gene Aire (autoimmune regulator) sobre redes de expressão gênica em células tímicas epiteliais medulares.

$\checkmark$ Bacharel em Ciências Biológicas pela Faculdade de Filosofia, Ciências e Letras de Ribeirão Preto (USP), no período de 1996 a 2000 - Diploma Registrado sob NO 1274474, processo 2001.1.325.59-0.

$\checkmark$ Licenciada em Ciências Biológicas pela Faculdade de Filosofia, Ciências e Letras de Ribeirão Preto (USP), no período de 1996 a 2000 - Diploma Registrado sob NO 1274475, processo 2001.1.325.59-0. 


\section{CURSOS DE EXTENSÃO UNIVERSITÁRIA}

$\checkmark$ "Transcriptome Analysis: Theoretical Basis and Applications", realizado no período de 29 de novembro a 2 de dezembro de 2005, INSERM Research Director Catherine Nguyen - Marseille, França, Departamento de Genética da Faculdade de Medicina de Ribeirão Preto-USP cumprindo carga horária total de 16 horas.

$\checkmark$ "Utilizando a técnica de RNA interference (RNAi) para silenciamento gênico", realizado durante o $49^{\circ}$ Congresso Nacional de Genética em Águas de Lindóia, SP, de 16 a 19 de setembro de 2003, com carga horária de 3 horas.

$\checkmark$ "Update on Genome Projects and Genomics", realizado no período de 25 a 28 de Setembro de 2000, CNRS emeritus Research Director Bertrand Jordan Marseille, França, Departamento de Genética, FMRP-USP, Ribeirão Preto, SP.

$\checkmark$ Curso e Simpósio "Tecnologia de microarrays - abordagem teórico-prática", realizado nos dias 6 e 7 de julho de 2000, IBiLCE - UNESP, São José do Rio Preto, SP.

$\checkmark$ "Large Scale Gene Expression Measurement Using DNA-arrays", realizado no período de 2 a 6 de agosto de 1999, INSERM Research Catherine Nguyen Marseille, França, Departamento de Genética da Faculdade de Medicina de Ribeirão Preto-USP cumprindo carga horária total de 48 horas.

$\checkmark$ "Diversidade Genética e Evolução do Sistema Imune", realizado durante o $44^{\circ}$ Congresso Nacional de Genética em Águas de Lindóia, SP, de 9 a 12 de setembro de 1998, com carga horária de 3 horas.

$\checkmark$ "Genética Molecular do Sistema Imune e Engenharia de Anticorpos", realizado durante o $44^{\circ}$ Congresso Nacional de Genética em Águas de Lindóia, SP, de 9 a 12 de setembro de 1998, com carga horária de 3 horas.

$\checkmark$ "Aspectos Moleculares da Regulação Gênica", realizado durante a Semana de Bio-estudos 1997, na FFCLRP-USP, de 3 a 7 de novembro, com carga horária de 20 horas.

$\checkmark$ "Interface Imunologia Genética", realizado durante a Semana de Bio-estudos 1996, na FFCLRP-USP, de 4 a 8 de novembro, com carga horária de 9 horas.

$\checkmark$ "Imunologia Básica", realizado na FFCLRP-USP, em novembro de 1996, com carga horária de 12 horas.

\section{ESTÁGIOS}

- Laboratório de Imunogenética Molecular do Departamento de Genética da Faculdade de Medicina de Ribeirão Preto-USP - sob orientação do Prof. Dr. Geraldo A.S. Passos, no período de julho de 1997 a dezembro de 2000. 


\section{ESTÁGIO NO EXTERIOR}

- Laboratório INSERM ERM 206, (TAGC - Tecnologies Avancées pour lê Génome et la Clinique) localizado na cidade de Marseille, França e dirigido por Catherine Nguyen Com linha de pesquisa voltada para estudos de Transcriptoma, utilizando a tecnologia dos Microarrays Humanos e Murinos. Fevereiro a outubro de 2006.

\section{MONITORIAS E AULAS PRÁTICAS}

1) Instituição: FMRP-USP

XIII Curso de Verão de Genética: Departamento de Genética (graduação)

Data: 14 janeiro a 25 de Janeiro de 2008.

Título: Noções Práticas sobre a aplicação de cDNA-microarrays.

2) Instituição: FMRP-USP

X Curso de Verão de Genética: Departamento de Genética (graduação)

Data: 31 janeiro a 06 de fevereiro de 2005.

Título: Noções Práticas sobre a aplicação de cDNA-microarrays.

3) Instituição: FMRP-USP

VIII Curso de Verão em Genética: Departamento de Genética (graduação)

Data: 3 a 7 de fevereiro de 2003.

Título: Análise da expressão Gênica em larga escala utilizando DNA-arrays.

4) Instituição: CRBio- $1^{\mathrm{a}}$ Região

$13^{\circ}$ Encontro de Biólogos do CRBio-1 (SP,MT,MS)

Data: 25 a 28 de março de 2002.

Monitora.

5) Instituição: CRBio- $1^{\mathrm{a}}$ Região

$11^{\circ}$ Encontro de Biólogos do CRBio-1 (SP,MT,MS)

Data: 17 a 20 de abril de 2000.

Monitora.

6) Instituição: FFCLRP-USP

Disciplina "Genética Molecular e Citogenética Básica e Aplicada".

Data: $2^{\circ}$ sementre de 1999.

Monitora Voluntária de Estágio teórico-prático.

7) Instituição: FFCLRP-USP

Disciplina "Genética".

Data: $1^{\circ}$ sementre de 1999.

Monitora Voluntária de Estágio teórico-prático.

8) Instituição: FFCLRP-USP

Disciplina "Elementos de Anatomia e Fisiologia Humana".

Data: $1^{\circ}$ sementre de 1997.

Monitora Voluntária de Estágio teórico-prático. 


\section{PALESTRAS PROFERIDAS}

- Palestra intitulada "Uso de cDNA-microarrays na identifição de genes envolvidos no processo de carcinogênese". Apresentada durante o XIII Curso de Verão de Genética no Departamento de Genética da Faculdade de Medicina de Ribeirão Preto - USP, no período de 14 a 25 de janeiro de 2008.

- Palestra intitulada "Uso de cDNA-microarrays na identifiç̧ão de genes envolvidos no processo de carcinogênese". Apresentada durante o X Curso de Verão de Genética no Departamento de Genética da Faculdade de Medicina de Ribeirão Preto - USP, no período de 17 a 28 de janeiro de 2005.

- Palestra intitulada "Análise da expressão gênica em larga escala utilizando cDNA-arrays. Apresentada durante o VIII Curso de Verão de Genética no Departamento de Genética da Faculdade de Medicina de Ribeirão Preto USP no período de 20 a 31 de janeiro de 2003.

\section{EXPERIÊNCIA DIDÁTICA}

Estágio de Licenciatura com carga horária de 360 horas distribuídos em colégios de Ensino Fundamental e Médio, da rede pública de ensino de Ribeirão Preto, São Paulo, com aplicações práticas das teorias dos Cursos de Graduação: "Didática I e II", "Programação de Curso", "Prática de Ensino em Ciências" e "Prática de Ensino em Biologia".

\section{PRODUÇÃO CIENTÍFICA}

\section{A) TRABALHOS PUBLICADOS EM PERIÓDICOS (COMPLETO)}

1) Sousa-Cardoso R, Magalhães DAR, Baião AMT, Junta CM, Macedo C, Marques MMC, Sakamoto-Hojo ET, Donadi EA, Passos GAS Onset of Promicuous Gene Expression in Murine Fetal Thymus Organ Culture (FTOC). Immunology. Londres.Vol aceito. 2006.

2) Cardoso RS, Junta CM, Macedo C, Silveira ELV, Paula MO, Marques MMC, Magalhães DAR, Mello SS, Záráte-Bladés CR, Nguyen C, Houlgate R, Donadi EA, Sakamoto-Hojo ET, Passos, GAS Hybridization Signatures of GammaIrradiated Murine Fetal Thymus Organ Culture (FTOC) Reveal Modulation of Genes Associated with V (D) J Recombination and DNA Repair. Mollecular Immunology. Oxford: v. 43, p. 464-472, 2006.

3) Magalhães DAR, Macedo C, Junta CM, Mello SS, Marques MMC, Cardoso RS, Sakamoto-Hojo ET, Donadi EA, Passos, GAS Hybridization Signatures During Thymus Ontogeny Reveals Modulation of Genes Coding for T-cell Signaling Proteins. Molecular Immunology. Oxford: v.42, n.9, p.1043 - 1048, 2005.

4) Macedo C, INITIATIVE, The Ludwig Fapesp Transcript Finishing. A 
transcript finishing initiative for closing gaps in the human transcriptome.. Genome Research. , v.14, p.1413 - 1423, 2004.

5) Espanhol AR, Macedo C, Junta CM, Cardoso RS, Victorero G, Loriod B, Nguyen C, Jordan B, Passos GAS. Gene expression profiling during thymus ontogeny and its association with TCRVB8.1-DB2.1 rearrangements of inbred mouse strains. Molecular and Cellular Biochemistry. , v.252, p.223 - 228, 2003.

6) Sandrin-Garcia P, Macedo C, Martelli LR, Ramos ES, Guion-Almeida ML, Richieri-Costa A, Passos GAS. Recurrent 22q11.2 deletion in a sibship suggestive of parental germline mosaicism in velocardiofacial syndrome.. Clinical Genetics. , v.61, p.380 - 383, 2002.

7) Macedo C, Junta CM, Passos GAS. Onset of T-cell receptor V 8.1 and D 2.1 $\mathrm{V}(\mathrm{D}) \mathrm{J}$ recombination during thymus development of inbred mouse strains.. Immunology Letters. , v.69, p.371 - 373, 1999.

\section{B) TRABALHOS SUBMETIDOS}

1) Macedo C; Magalhães DAR; Tonani M; Marques MMC; Junta CM; Passos GAS. Genes coding for $\mathrm{T}$ cell signaling proteins establish transcriptional regulatory networks during thymus ontogeny. Artigo Submetido.

\section{C) TRABALHOS PUBLICADOS EM ANAIS (RESUMOS) EM CONGRESSOS NO BRASIL}

1) Macedo C; Magalhães DAR; Tonani M; Marques MMC; Junta CM; Passos GAS. Transcriptional regulation during thymus ontogeny reveals networks between genes coding for $\mathrm{T}$ cell signaling proteins. $53^{\circ}$ Congresso Brasileiro de Genética, 2007, Águas de Lindóia.

2) Magalhães DAR; Macedo C; Joly F; Loriod B; Boulanger N; Victorero G; Puthier D ; Nguyen C; Passos GAS. Molecular Dissection of the Mouse Thymus Based on Cell-Type Specific Gene Expression. 53 Congresso Brasileiro de Genética, 2007, Águas de Lindóia.

3) Magalhães DAR; Macedo C; Joly F; Puthier D; Loriod B; Boulanger N; Victorero G; Nguyen C; Passos GAS. Identification of Specific T-Cell Gene Expression Profiles During the Fetal Thymus Maturation. $52^{\circ}$ Congresso Brasileiro de Genética, 2006, Foz do Iguaçu.

4) Macedo C; Junta CM; Sandrin-Garcia P; Fachin AL; Sakamoto-Hojo ET; Donadi EA; Passos GAS. Assinaturas de expressão gênica de células mononucleares sanguíneas e sua relação com a indução de câncer pelo metilcolantreno. $51^{\circ}$ Congresso Brasileiro de Genética, 2005, Águas de Lindóia SP. 
5) Magalhães DAR; Junta CM; Macedo C; Sandrin-Garcia P; Mello SS; Fachin AL; Sakamoto-Hojo ET; Donadi EA; Passos GAS . Identification of genes preferentially expressed by the thymus during ontogeny. $51^{\circ}$ Congresso Brasileiro de Genética, 2005, Águas de Lindóia - SP.

6) Lobo, CH; Magalhães DAR; Francoy, TM; Macedo C; Brassesco, MS. Presença de NORs em uma linhagem celular de Appis mellifera testada por FISH e AgNO3. $51^{\circ}$ Congresso Brasileiro de Genética, 2005, Águas de Lindóia SP.

7) Paula MO; Zárate-Bladés CR; Silveira EL; Fachin AL; Junta CM; Mello SS; Magalhães DAR; Macedo C; Sandrin-Garcia P; Silva CL; Donadi EA; SakamotoHojo ET; Passos GAS . Interleukin 7 modulates the gene expression in murine adult thymus organ culture. XXIX Meeting of Brazilian Society of Immunology, 2004, Ouro Preto - MG.

8) Magalhães DAR; Junta CM; Macedo C; Sandrin-Garcia P; Mello SS; Fachin AL; Silveira EL; Paula MO; Zárate-Bladés CR; Sakamoto-Hojo ET; Donadi EA; Passos GAS . cDNA MICROARRAYS MAY POTENTIALLY IDENTIFY NEW CANDIDATES GENES THAT MODULATE THE IN VIVO T CELL MATURATION. XXIX Meeting of Brazilian Society of Immunology, 2004, Ouro Preto - MG.

9) Zárate-Blades CR; Silveira EL; Paula MO; Fachin AL; Junta CM; Magalhães DAR; Macedo C; Donadi EA; Sakamoto-Hojo ET; Passos GAS. High-Troughput gene expression profile of Mycobacterium tuberculosis infected mice treated with two distinct hsp65-DNA vaccines. XXIX Meeting of the Brazilian Society of Immunology, 2004, 2004, Ouro Preto.

10) INITIATIVE, The Ludwig Fapesp Transcript Finishing ; Macedo C. Transcript Finishing Initiative (Tfi): New Genes Identification And Annotation.. XXXII Reunião Anual da Sociedade Brasileira de Bioquímica e Biologia Molecular, 2003, Caxambu.

11) Magalhães DAR; Junta CM; Macedo C; Mello SS; Marques MMC ; Cardoso RS; Sakamoto-Hojo ET; Donadi EA; Passos GAS. Uso de cDNA microarrays na identificação de novos genes candidatos à modulação da recombinação $\mathrm{V}(\mathrm{D}) \mathrm{J}$ dos receptores de células T (TCR). $49^{\circ}$ Congresso Nacional de Genética, 2003, Águas de Lindóia - SP.

12) Magalhães DAR; Macedo C; Junta $C M$; Passos GAS . Emergência da recombinação $\mathrm{V}(\mathrm{D}) \mathrm{J}$ de TCRV 8.1 e análise da expressão gênica no timo de heteozigotos entre linhagem isogênica de camundongos. $13^{\circ}$ Encontro de Biólogos - CRBio1, 2002, São Pedro.

13) Magalhães DAR; Macedo C; Junta CM; Passos GAS . Detecção do início da recombinação $\mathrm{V}(\mathrm{D}) \mathrm{J}$ durante a ontogenia do timo de heterozigotos entre 
linhagens isogênicas de camundongos. $48^{\circ}$ Congresso Nacional de Genética, 2002, Águas de Lindóia. Genetics end Molecular Biology, 2002.

14) INITIATIVE, The Ludwig Fapesp Transcript Finishing; Macedo C The Transcript Finishing Iniciative (Tfi) Project Transcript Finishing Consortium. XXXI Reunião Anual da Sociedade Brasileira de Bioquímica e Biologia Molecular (SBBq), 2002, Caxambu-MG.

15) Passos GAS; Junta CM; Espanhol AR; Macedo C; Bertrand J; Nguyen C; Victorero G; Loriod B; Granjeaud, S. Using DNA-arrays to search new genes expressed in the thymus during V(D)J recombination of T-cell receptor (TCR V 8.1). $45^{\circ}$ Congresso Nacional de Genética., 1999, Gramado. Genetics and Molecular Biology.

16) Macedo C; Junta CM; Passos GAS. Onset of T-cell receptor Vb8.1 and Db2.1 $\mathrm{V}(\mathrm{D}) \mathrm{J}$ recombination during thymus development of inbred mouse strains. In: International Meeting on Vaccines, 1998, Salvador-BA.

\section{D) TRABALHOS PUBLICADOS EM CONGRESSOS E/OU REUNIÕES CIENTÍFICAS NO EXTERIOR}

1) Magalhães DAR, Macedo C, Junta CM, Mello SS, Marques MMC, Cardoso RS, Sakamoto-Hojo ET, Donadi EA, Passos GAS. Association of T-cell receptor beta (TRBV8.1-DB2.1) rearrangement with hybridization Signatures During Thymus Ontogeny. In: 6th International Meeting of Microarrays Gene Expression Data Society (MGED), 2003, Aix en Provence-France, 2003.

2) Espanhol AR; Macedo C; Junta CM; Cardoso RS; Victorero G; Loriod B; Nguyen C; Bertrand J; Passos GAS . Genes Differentially Expressed during TCR V 8.1-D 2.1 rearrangements in vivo in the thymus of inbred mouse strains.. In: 11thInternational Congress of Imunology. 2001, Stockholm. Scandinavian Journal of Immunology. Stockholm: Blackwell Science, 2001. v. 54. p. 9-9.

\section{PRÊMIOS E TÍTULOS}

$1^{0}$ Prêmio de Apresentação de Trabalhos concedido pela Comissão de Avaliação de Painéis do Conselho Regional de Biologia - $1^{\text {a }}$ região, com o trabalho entitulado "Emergência da recombinação V(D)J de TCRVB8.1 e análise da expressão gênica no timo de heterozigotos entre linhagens isogênicas de camundongos" apresentado durante o $13^{\circ}$ Encontro de Biólogos do CRBio-1 realizado em São Pedro - SP de 25 a 28 de março de 2002.

\section{RELATOR DE TRABALHOS}

Atuação como avaliadora na área de Genética, no $12^{\circ}$ SICUSP- Simpósio de Iniciação Científica da Universidade de São Paulo- Áreas Ciências Biológicas, 
realizado pela Comissão de Pesquisa da Faculdade de Filosofia, Ciências e Letras da USP no Centro de Convenções de Ribeirão Preto em 23 de dezembro de 2004, com carga horária de 3 horas.

\section{PARTICIPAÇÃO EM CONGRESSOS E REUNIÕES CIENTÍFICAS NO BRASIL}

- $53^{\circ}$ Congresso Brasileiro de Genética, realizado em Águas de Lindóia-SP no período de 2 a 5 de setembro de 2007.

- $51^{\circ}$ Congresso Brasileiro de Genética, realizado em Águas de Lindóia-SP no período de 7 a 10 de setembro de 2005.

- VI Simpósio Nacional de Biologia Molecular Aplicada à Medicina, realizado em Santos-SP de 8 a 9 de abril de 2005

- $49^{\circ}$ Congresso Nacional de Genética, realizado em Águas de Lindóia-SP de 16 a 19 de setembro de 2003.

- $48^{\circ}$ Congresso Nacional de Genética, realizado em Águas de Lindóia-SP de 17 a 20 de setembro de 2002.

- $13^{\circ}$ Encontro de Biólogos - CRBio1, realizado em São Pedro-SP de 25 a 28 de março de 2002.

- Simpósio dos 30 anos da Pós-Graduação em genética da FMRP-USP, dias 14 e 15 de dezembro de 2001.

- Brazilian Internacional Genome Conference, realizado em Angra dos Reis-RJ de 26 a 29 de março de 2001.

- $11^{\circ}$ Encontro de Biólogos - CRBio1, realizado em São Pedro-SP de 17 a 20 de abril de 2000.

- $45^{\circ}$ Congresso Nacional de Genética, realizado em Gramado-RS de 3 a 6 de outubro de 1999.

- International Meeting on Vaccines, realizado em Salvador-BA de 29 de novembro a 3 de dezembro de 1998.

- $44^{\circ}$ Congresso Nacional de Genética, realizado em Águas de Lindóia-SP de 9 a 12 de setembro de 1998 . 


\section{BOLSAS DE ESTUDO}

- Bolsa de Iniciação científica concedida pela FAPESP Fundação de Amparo à Pesquisa do Estado de São Paulo), para o desenvolvimento do projeto de iniciação científica: Emergência da recombinação $V(D) J$ no lócus TCRB durante a ontogenia do timo, sob a orientação do Prof. Dr Geraldo A.S. Passos.

- Bolsa de Doutorado concedida pelo CNPq (Conselho Nacional de Desenvolvimento Científico e Tecnológico) na área de Genética, para o desenvolvimento do projeto da tese de Doutorado, sob a orientação do Prof. Dr Geraldo A.S. Passos .

- Bolsa de Estágio de Doutorado (Doutorado-Sanduíche) concedida pelo CNPq (Conselho Nacional de Desenvolvimento Científico e Tecnológico) na área de Genética, pelo período de fevereiro a outubro de 2006, sob a orientação do Prof. Dr Geraldo A.S. Passos, no Brasil, e supervisão da Dra. Catherine Nguyen, diretora da unidade INSERM ERM 206, Marseille - França.

\section{Proficiência em Línguas}

- Certificado de Proviciência em Francês "Test de Français" aplicado pela "Délègation Générale de L'Alliance Française au Brésil" com nível bom no francês oral e escrito, realizado no dia 19 de agosto de 2005.

- TEAP - Test of English for Academic Purposes na área de Saúde/ Biológicas e obtido pontuação (0-10) 7,5 - Tese Prime - TB03/005 em 05 de novembro de 2002, Ribeirão Preto-SP.

\section{Claudia Macedo}


Publicacões 
Genes coding for T cell signaling proteins establish transcriptional regulatory networks during thymus ontogeny

Cláudia Macedo ${ }^{1+}$, Danielle A. Magalhães ${ }^{1+}$, Monique Tonani ${ }^{1}$, Márcia C. Marques ${ }^{1}$, Cristina M. Junta ${ }^{1}$, Geraldo A. S. Passos ${ }^{1,2}{ }^{*}$

1) Molecular Immunogenetics Group, Department of Genetics, Faculty of Medicine, University of São Paulo (USP), 14040-900, Ribeirão Preto, SP, Brazil.

2) Discipline of Genetics, Department of Morphology (DMEF), Faculty of Dentistry, USP, 14040-904, Ribeirão Preto, SP, Brazil.

+ These authors contributed equally to this study

* Send correspondence to:

Dr. Geraldo A. S. Passos

Molecular Immunogenetics Group

Department of Genetics

Faculty of Medicine of Ribeirão Preto, USP

14040-900 Ribeirão Preto, SP, Brazil.

Tel +551636023030 Fax +551636330069

E-mail passos@rge.fmrp.usp.br 


\section{Abstract}

The definition of gene expression profiling by cDNA microarrays during murine thymus ontogeny has contributed to dissecting the large-scale molecular genetics of T cell maturation. Gene profiling, although useful for characterizing the thymus developmental phases and identifying the differentially expressed genes, does not permit the determination of possible interactions between genes. In order to reconstruct genetic interactions during a murine thymus period of development, which is important for thymocyte differentiation (14-17 days of gestation), a pair of microarrays was used containing a total of 1,576 cDNA sequences derived from the IMAGE MTB library, whose data were analyzed using the GeneNetwork program. Characteristic interactions involving genes were observed during thymus ontogeny, which were previously identified as differentially expressed and once included in a network, showed their relationships with several other genes. The present method provided the detection of gene nodes implicated in the calcium signaling pathway, such as Prr2 and Stxbp3, and in protein transport towards the cell membrane, such as Gosr2. The results demonstrate the feasibility of reconstructing networks based on cDNA microarray gene expression determinations, contributing to a clearer understanding of the complex interactions between genes involved in thymus/thymocyte development.

Keywords Thymus development, gene expression, microarray, gene networks 


\section{Introduction}

The thymus is an important organ implicated in the control of the main functions of the immune system, providing a specialized microenvironment for the maturation of thymocytes into positive TCR $\alpha / \beta$ T cells $[1,2]$. Organ functioning begins early during fetal development, when immature thymocytes from the bone marrow reach the thymus and thousand of genes are simultaneously modulated in both, with thymocytes and thymic stroma contributing to tolerance induction to self-antigens [3-8].

Deciphering these genes is a complex task and DNA microarray technology, including mathematical and statistical algorithms for data analysis, such as hierarchical clustering [9] and significance analysis of microarrays (SAM) [10], have permitted the description of the modulation of several of such genes, featuring gene expression signatures $[6-8,11]$.

Recent subsuming realized that most biochemical relationships among genes act in a synchronized fashion, involving many genes at once, in which one gene can exert many functions and one function can be exerted by many genes [12].

Accordingly, a biological phenomenon needs to be interpreted as a whole biochemical system and in order to grasp it, a comprehensive data set needs to be produced.

One example of a highly complex biochemical system is thymocyte differentiation into mature $T$ cells. It occurs within the fetal thymus and all developmental stages are distinguishable by their expression of a combination of clusters of differentiation (CD) cell-surface markers.

This is a highly modulated phenomenon, whose central molecular machinery is formed by the recombinase complex (RAG-1 and RAG-2) directly implicated 
in the $V(D) J$ recombination of $T$ cell receptor gene segments (TRA, TRB, TRG and TRD) [13].

The early fetal thymus has homogeneous cell populations composed of lymphoid progenitors derived from the bone marrow, which is formed by doublenegative (DN1), CD44 high $C D 25^{+}$(DN2), CD44 ${ }^{\text {low }} \mathrm{CD} 25^{+}$(DN3), and CD44 ${ }^{\text {low }}$ $\mathrm{CD}^{-}$(DN4) thymocytes. During $\mathrm{DN}$ to $\mathrm{CD}^{+} \mathrm{CD} 8^{+}$double-positive (DP) transition, thymocytes relocate to the thymic cortical region, where most do not recognize the available MHC molecules expressed by thymic stromal cells and die as a result.

The remaining DP thymocytes undergo negative selection occurring both in the cortex and in medulla, leading to the deletion of autoreactive clones and favoring MHC-restricted CD4 and CD8 single-positive $\mathrm{T}$ cells $\left(\mathrm{CD} 4^{+} \mathrm{SP}\right.$ and $\left.\mathrm{CD} 8^{+} \mathrm{SP}\right)$, which finally gain the periphery $[14,15]$.

In contrast, the newborn and adult thymus is the arrival place of new colonizing precursors, which contribute to the formation of heterogeneous cell populations, including macrophages and dendritic cells [16].

Studies on temporal V(D)J recombination of TRA and TRB genes $[17,18]$ and differential expression of immune system-related genes, such as interleukins and the major histocompatibility complex (MHC) [19] during thymus ontogeny, showed that the genetic background of different inbred mouse strains plays an important role in the modulation of the emergence of T cell maturation.

The cDNA microarray, as a high-throughput functional genomic technology, provides comparative analysis between the different phases of thymus ontogeny, yielding quantitative expression data of hundreds or thousands of genes in a single experiment. Research on gene expression during thymus 
ontogeny using such technology has been the subject of extensive studies [6$8,11,20-22]$.

Nevertheless, current understanding regarding the molecular pathways of thymocyte maturation is still considered as fragmented and the results often remain difficult to situate in an integrated and dynamic view of $T$ cell differentiation [6].

Recently a high-throughput data set containing thousands of gene expression values during murine thymus ontogeny, including nonmanipulated and knockout strains, was generated by cDNA microarray technology and analyzed by SAM or hierarchical clustering programs $[6-8,11]$, which permitted the monitoring of numerous differentially expressed genes simultaneously.

The differentially expressed genes identified by SAM statistics and grouped by hierarchical clustering provided a valuable data set for new insights into how these genes could interact with each other.

In this study, the interactive relationships of constructing networks among these differentially expressed genes of thymus development observed during the gestational period of (Balb-c $\times$ C57BI/6) $\mathrm{F}_{1}$ hybrid mice were evaluated.

Hybridization data from nylon cDNA microarrays containing a total of 1,576 thymus IMAGE sequences were analyzed using the GeneNetwork 1.2 software [12], whose results showed that each phase of thymus development exhibited a characteristic interaction between genes, permitting the identification of important genetic nodes, i.e., genes that exert an inductive/repressive effect on other genes or contrary to this, are the targets of several other genes. 
Among the genetic nodes observed, those implicated in intracellular protein transport were the most interactive, which may represent important genetic cascades during the development of the thymus/thymocytes.

\section{Material and methods}

\section{Fetal thymus and RNA preparation}

The (qBalb-c $\times \quad \stackrel{C}{C} 57 \mathrm{BI} / 6) \quad \mathrm{F}_{1}$ hybrid mice were obtained in our own laboratory. The animals were maintained in a $0.45 \mu$ air filtered isolator, on a 12 hour light/dark cycle, a temperature of $23^{\circ} \mathrm{C} \pm 2{ }^{\circ} \mathrm{C}$ and feed and water ad libitum. Pregnant Balb-c females were sacrificed by cervical dislocation and the fetuses were surgically collected from the uterus. The age of the fetuses (in days post coitum, p.c.) was confirmed on the basis of the morphological characteristics of each development phase [23] (Rugh, 1968). Thymic samples collected from 14 to 17 days p.c. were used, a stage when the maturation of the thymocytes and the emergence of the $T$ cell receptor $V$ beta genes occur $[7,18]$.

Fetal thymus tissue ( $1 \mathrm{mg}$ containing approximately $1 \times 10^{7}$ cells) was obtained by surgery under a stereomicroscope and immediately processed for total RNA extraction using Trizol ${ }^{\circledR}$ reagent (Invitrogen). Only protein- and phenol-free RNA preparations were used, as determined by UV spectrophotometry, and those featuring native undegraded RNA species in standard denaturing agarose gel electrophoresis.

\section{cDNA microarray method}

A pair of cDNA microarrays was used, containing a total of 1,576 clones in the form of PCR products, spotted in duplicate on $2.5 \times 7.5 \mathrm{~cm}$ Hybond $\mathrm{N}+$ nylon membranes (GE Healthcare). The arrays were prepared in our own 
laboratory using a Generation III Array Spotter (Amersham-Molecular Dynamics, Sunnyvale, CA, USA). The complete file providing all genes present in the microarrays used in this study is available online at (http://rge.fmrp.usp.br/passos/nylon_array/mtb1).

Mouse expressed sequence tag (EST) cDNA clones were obtained from the Soares thymus 2NbMT normalized library, prepared from a C57BI/6J 4-weekold male thymus, and available at the I.M.A.G.E. Consortium (http://image.Ilnl.gov/image/html/iresources.shtml).

cDNA inserts were homogeneous in size (approximately $1 \mathrm{~Kb}$ ) and cloned in three vectors (pT7T3D, pBluescript and Lafmid) and were amplified in 384- or 96-well plates using vector-PCR amplification with the following primers, which recognize the three vectors, LBP 1S 5'-GTGGAATTGTGAGCGGATACC-3' forward and LBP 1AS 5'-GCAAGGCGATTAAGTTTGG-3' reverse.

The membranes were first hybridized with the LBP 1AS[ $\left[\gamma^{33} \mathrm{P}\right] \mathrm{dCTP}$ (GE Healthcare, USA) labeled oligonucleotide (vector hybridization). Quantification of the signals obtained permitted the estimation of the amount of DNA deposited in each spot. After stripping, the membranes were subsequently used for hybridization with thymus cDNA complex probes (sample hybridization).

The annotation of each cDNA sequence was updated using S.O.U.R.C.E. (http://genome-www5.stanford.edu/cgi-bin/source/sourceSearch) and DAVID (http://david.abcc.ncifcrf.gov) databases, allowing for a set of information: gene name, sequence, biological and molecular functions. 


\section{Complex cDNA probe preparation and hybridization}

In this study, we refer to the radioactive cDNA originated from the thymus RNA samples as the complex probe and the PCR product originated from the clones and deposited on the nylon microarrays as the target.

The ${ }^{33}$ P-labeled CDNA complex probes were prepared by reverse transcription of $10 \mu \mathrm{g}$ of thymus total RNA using oligo $\mathrm{dT}_{12-18}$ as a primer. One hundred microliters of ${ }^{33} \mathrm{P}-\mathrm{cDNA}$ complex probe containing 30 - 50-million $\mathrm{cpm}$ was hybridized with nylon microarrays, as previously described [24-27].

\section{Imaging acquisition}

Imaging plates and a phosphor imager storage system (Cyclone model, Packard Instruments, USA) were used to capture the hybridization signals and the Array Vision ${ }^{\circledR}$ (Imaging Research Inc. USA) was used to quantify the signals with local background subtraction, whose spots were matched with a template grid.

The ratio between vector probe hybridization values and complex probe hybridization values for each spot was used as a reference normalization value. Total intensity normalization, using the median expression value, was also used [28]. 


\section{cDNA microarray data analysis}

\section{Statistics}

The gene expression data analyzed here were obtained from three independent determinations for each day of fetal development.

The SAM method (Significance Analysis of Microarrays), available online at http://www-stat.stanford.edu/ tibs/SAM/index.html [10], was used to analyze the significant variations in the gene expression. This method is based on $t$ test statistics, specially modified for high-throughput analysis. Significant variations in gene expression of the developing thymus were compared with that found at 14 days p.c. (14 vs 15,14 vs 16 and 14 vs 17 days of gestation). The program calculates the chance of global error and the false discovery rate (FDR) and, in this study, data from genes with FDR $\leq 0.05$ was used.

\section{Gene networks}

The GeneNetwork 1.2 algorithm [12] was used to compare means of different gene expression values whose standard deviation did not overlap, whose objective was to compute a network that established relationships between all genes. The linear interpolation for the network organization was used. The software for this algorithm can be obtained from the authors (http://idv.sinica.edu.tw/hchuang/GeneNetwork1.2Setup.exe).

In order to organize networks only with genes whose expression values were significant, values for the induced and repressed genes selected by the SAM statistics were used. In this case, of the 1,576 sequences present on the microarrays, a total of 104 (from 14 vs 15 days p.c.), 63 (from 14 vs 16 days p.c.) and 39 (from 14 vs 17 days p.c.) differentially expressed genes were included in the calculations of the GeneNetwork software due to their statistical significance. 
Finally, to evaluate the consistency of the results obtained, the networks developed by our group were compared to those reported in the literature and compiled by the Kyoto Encyclopedia of Genes and Genomes (KEGG) database (http://www.genome.jp/kegg/).

\section{Results}

\section{Differentially expressed genes}

To identify significant changes in gene expression during fetal development of the thymus, the stage when the thymocytes mature and the onset of $\mathrm{T}$ cell receptor $\mathrm{V}$ beta 8.1 (TRBV8.1) recombination occurs in the (oBalb-c $\mathrm{x}$ C $57 \mathrm{BI} / 6) \mathrm{F}_{1}$ hybrid mice (at 14 days of gestation p.c.) was compared with those observed on subsequent days (14 vs 15, 14 vs 16 and 14 vs 17 days p.c.). The demarcation of the emergence of TRBV8.1 recombination in these hybrid mice was realized in a previous study by our group [7] and confirmed in the samples used in this study (data not shown).

A scatter plot of the observed relative difference $d(i)$ versus the expected relative difference $d_{E}(i)$ was used, as shown by the SAM program.

Most of the 1,576 sequences tested presented $d(i) \approx d_{E}(i)$, i.e., their expression pattern did not change; however, some genes were significantly modulated during thymus development, which were then analyzed in the GeneNetwork program (Fig. 1). 


\section{Gene networks}

As previously mentioned, the data of the significantly expressed genes revealed by the SAM statistics were input into the GeneNetwork 1.2 program to visualize their possible relationships during thymus development.

The early thymus ( 14 vs 15 days p.c.) was the most dynamic in terms of gene interactions. Of the 104 differentially expressed genes in this phase, a set of 21 were found to participate in this network; these represent gene nodes (Fig. 1a).

The subsequent days of development featured 12 gene nodes at 14 vs 16 days p.c. (Fig. 1b) and eight gene nodes at 14 vs 17 days p.c. (Fig. 1c), participating in their respective networks. The remaining 83 (14 vs 15 days p.c.), 51 (14 vs 16 days p.c.) and 31 genes (14 vs 17 days p.c.), although differentially expressed, do not appear in these networks.

Four possible types of interactions were observed between gene nodes participating in the networks. The first type was positive interaction, i.e. when a gene $g$ positively regulated a gene $h(g \rightarrow h)$, the second was a negative interaction, i.e. when a gene $g$ negatively regulated a gene $h(g \rightarrow h)$, the third featured simultaneous positive interactions, i.e. when a gene $g$ positively regulated a gene $h$ and vice-versa $(g \leftrightarrow h)$ and the fourth was a positive selfinteraction, i.e. when a gene $g$ positively regulated itself $(g \leftrightarrow g)$.

\section{Discussion}

Two widely used methods for microarray data analysis are the Cluster-andTree View [9], which is based on a mathematical description of similarity and the organization of gene expression data is realized by grouping together genes with similar patterns of expression (hierarchical clustering), and the Significance 
Analysis of Microarray (SAM) [10], which is based on $t$ test statistics specifically developed for high-throughput microarray data.

Although these methods are useful tools for the identification of differentially expressed genes, they not permit the determination of interactions between genes.

There are several computational solutions proposed in the literature to infer gene networks; the approaches based on the mathematical formalism of the information theory as ARACNE proram [29,30], the algorithms that consider ordinary differential equations as NIR, NMI and TSNI programs [31-33] and those which solve the inference problem by means of Bayesian networks as Banjo [34] and GeneNetwork [12] programs.

Comparing the algorithms, GeneNetwork was chosen for the analysis purposes due to its differential features. The algorithm realizes the interpolation of data and is able to handle with more than one thousand of genes. Moreover, the resulting network is described by an oriented graph in which positive arrows indicate induction and negative ones denote repression between genes.

In an effort to provide a clearer understanding of the high-throughput data resulting from microarray experiments and to establish regulatory gene interactions during murine thymus ontogeny, normalized data were analyzed by the GeneNetwork program [12], which is based on dynamic Bayesian statistics inferring gene networks.

Recently, gene networks were reconstructed based on microarray data studying model organisms, such as S. cerevisiae [35], E. coli [36] and Drosophila [37]. Additionally, gene networks were reconstructed for mammalian 
cells, including human herpesvirus-infected $T$ cells [38] and astrocyte differentiation in rat cells [39].

To the best of our knowledge, this is the first study showing gene network reconstruction from microarray data during normal thymus development. Three networks were reconstructed, corresponding to a period of thymus ontogeny important for the differentiation of thymocytes to mature $\mathrm{T}$ cells, in which it was possible to indicate gene nodes, i.e., genes establishing positive and/or negative interactions with other genes, including self-regulation. It is subsuming that nodes represents the main points in the control of genetic cascades.

We agree with the discussion of de La Fuente that networks obtained with only part of a genome, as is the case of the set of genes examined in this study, are still useful representation of the underlying gene regulatory structure. Accordingly, if a gene $A$ influences the expression of gene $B$ through the action of gene $C$, but gene $C$ is not known (or its oligo/cDNA sequence was not included in the microarray used), the gene network algorithm will find a regulatory effect of $A$ on $B$ [40].

For this reason, and trying to minimize this oversight, in this study only gene nodes establishing self-regulation and/or at least three interactions with other genes and whose pathways were confirmed in the KEGG pathway data base were selected for discussion.

The significantly modulated genes during thymus ontogeny featured nodes in the three networks establishing positive or negative interaction among them.

As mentioned, 14-15 days of gestation p.c. was the most dynamic phase in terms of gene interactions (Fig. 1A). Genes implicated in the calcium signaling pathway, such as the Proline-rich Gla (G-carboxyglutamic acid) polypeptide 2 
gene, Prr2, (mRNA accession number NM_022999, ID 640686) and the Syntaxin binding protein 3 gene, Stxbp3, (mRNA accession number NM_011504, ID 640484), whose respective coded proteins play a role in the inhibition of the calcium influx pathway via calcineurin, correspond to important nodes in this and in subsequent phases.

These genes participate in the control of calcium influx pathway mediated by calcineurin, which is important in the activation of the nuclear factor of activated T cells (Nfat), a T cell transcription factor. As calcium signaling is implicated in the induction of T cell anergy mediated through calcineurin and NFAT [41-43], the nodes identified could be useful to provide a clearer understanding of the gene interactions implicated in the immunological tolerance induction.

Twenty-one gene nodes were identified at 14 vs 15 days p.c. and eight were selected for discussion:

1) The Prr2 is a gene node featuring self positive regulation, was positively regulated by 19 other genes (of the 21 found in the network) and was indirectpositively regulated by two others, i.e. two genes interacted first and then positively regulated the Prr2 gene; the Cope gene positively regulated the Prmt3 gene, which positively regulated the Prr2 gene: Cope $\rightarrow$ Prmt3 $\rightarrow$ Prr2. This strongly suggests the importance of maintaining the Prr2 gene transcription levels. A negative feedback-like regulation, between the Prr2 gene and Golgi SNAP receptor complex 2 gene, Gosr2, (mRNA accession number NM_019650, ID 640152) was found. While the Gosr2 gene positively regulates Prr2, the latter presented an inhibitory effect on Gosr2.

2) The Stxbp3a gene node also featured self positive regulation and was positively regulated by three genes participating in the network. However, this 
gene was mostly indirectly positively regulated. Even so, this strongly suggests the importance of maintaining the Stxbp3a transcription levels. Moreover, this gene presented an inhibitory effect on Gosr2.

3) The Protein arginine N-methyltransferase 3 enzyme gene, Prmt3, (mRNA accession number NM_133740, ID 639644) was another main node identified, participating in tryptophan and androgen/estrogen metabolism. This gene was positively self-regulated and positively regulated by 11 genes, including the Prr2 and Stxbp3a genes discussed above, and the Anaphase promoting complex subunit 2 gene, Anapc2, (mRNA accession number NM_175300, ID 640882), whose protein product is an essential component of the SCF (skp1-cul1-f-box protein) e3 ubiquitin ligase complex, which mediates the ubiquitylation of proteins involved in cell cycle progression, signal transduction and transcription.

4) The Zfp420 gene also participates as an important node, featuring positive self-regulation and positively regulated by other genes, such as Prmt3, Prrg2 and Stxbp3a. Interestingly, the positive interactions with these genes were bidirectional, i.e. Zfp420 $\leftrightarrow$ Prmt3, Zfp420 $\leftrightarrow$ Prg2 and Zfp420 $\leftrightarrow$ Stxbp3a, featuring a feedback-like interaction. Zfp420 gene presented an inhibitory effect on Gosr2.

5) The Gosr2 gene, whose coded protein is a SNARE member involved in intracellular protein transport, was also identified as a node. Gosr2, in its turn, was negatively regulated by the four genes discussed above (Stxbp3a, Prmt3, Prrg2 and the Zinger finger protein 420 gene, Zfp420, mRNA accession number NM_172740, ID 640711).

6-8) The participation of three transcribed loci was identified, none with an assigned function to date, characterizing three nodes. One of them (ID 639992) 
was positively self-regulated and was positively regulated by several other genes, including Prmt3, Prrg2 and Stxbp3a and these interactions were bidirectional, as mentioned above. The second transcribed locus (ID 574022) positively regulated Prmt3 and Prrg2 genes and was positively regulated by seven genes and indirectly regulated by several others. The third transcribed locus (ID 640082) defines a node positively regulated by three genes, Prrg2, Prmt3 and Zfp420. This strongly suggests that these sequences, although still anonymous, could play an important regulatory role during thymus development.

It was possible to define 12 nodes at 14 vs 16 days p.c., of which seven were chosen for discussion (Fig. 1B).

1) The Lunatic fringe gene homolog (Drosophila), Fringe (Lnfg), (mRNA accession number NM_008494, ID 640133), which participates in the Notch signaling pathway via delta receptor and is important for $\mathrm{T}$ cell differentiation, was identified as a gene node that positively regulated two genes (Dock8 and Cast) and two transcribed loci (ID 640292 and ID 640674).

2) The next gene node identified was the Gosr2 and, similar to that observed at 14 vs 15 days p.c., it was negatively regulated, in this case by two genes (Cast and Fringe) and by one transcribed locus (ID 640674).

3) The Cyclin-dependent kinase 4 gene, Cdk4, (mRNA accession number NM_009870, ID 640338) also was identified as a negatively regulated gene node, interacting with three genes (Dock8, Cast and Fringe) and two transcribed loci (ID 640292 and ID 640674). CDK4 is a late element participating in the $\mathrm{T}$ cell receptor signaling pathway, which starts with the attachment of CAM ligands of antigen presenting cells on TCR $\alpha / \beta$ on 
lymphocytes and finally associates with proliferation-differentiation molecules, such as Cdk4.

4) The Calpastatin gene, Cast, (mRNA accession number NM_009817, ID 640722) represents a dynamic gene node that was positively self-regulated, negatively regulated the Cdk4 gene and positively regulated by four genes (Fringe, Dock8, Emb and Kif3c) and two transcribed loci (ID 640292 and ID 640710). Their coded protein, calpastatin is a natural inhibitor of the enzyme calpain, which catalyzes protein cleavage.

5-6) The transcribed locus (ID 640674), although anonymous, represents another dynamic gene node, which was positively self-regulated, regulated by five genes (Cast, Lnfg, Dock8, Emb and Kif3c) and by two anonymous transcribed loci (ID 640292 and ID 640643). The anonymous transcribed locus (ID 640292) also featured a gene node, which was positively self-regulated, regulated by two genes (Cast and $L$ nfg) and by the anonymous transcribed locus (ID 640674). It positively regulated the Dock8 gene and negatively regulated the Cdk4 gene.

7) The Dedicator of cytokinesis 8 gene, Dock8, (mRNA accession number NM_028785, ID 639971), whose coded protein is a guanyl-nucleotide releasing factor, featured another gene node. Of the five gene interactions, four were positive, including a feedback-like interaction with the Cast gene (Dock8 $\leftrightarrow$ Cast) and three others; one with the Fringe gene and two with the transcribed loci, ID 640292 and ID 640674, respectively. Moreover, Dock8 negatively regulated the $C d k 4$ gene.

The network of 14 vs 16 days p.c. is particularly interesting, due to the presence of sequences uncharacterized in terms of their biological function, 
opening a new perspective for the discovery of genes participating in $\mathrm{T}$ cell differentiation.

Finally, 14 vs 17 days p.c. exhibited eight gene nodes, of which four were chosen for discussion (Fig. 1C).

1) The first gene node is represented by the Stxbp3a gene, which participates in intracellular protein traffic and transport. It was negatively regulated by itself, by the Tacc1 gene and by the transcribed locus (ID 640711) and positively regulated the Capicua homolog (Drosophila) gene, Cic (mRNA accession number NM_027882).

2) The Cic gene was also identified as a node, which was positively regulated by the Stxbp3a and Tacc1 genes and by the transcribed locus (ID 640711). This indicates that Cic gene node could play a role in the late phase of thymus development.

3) Another gene node identified was the Transforming acidic coiled-coilcontaining protein 1 gene, Tacc1 (mRNA accession number NM_177089, ID 640235), which is expressed at high levels during early embryogenesis and whose function is likely involved in the processes that promote cell division prior to the formation of differentiated tissues. This gene node was positively regulated by four others; the transcribed locus ID 640711 and the Prrg2, Gosr2 and Triobp genes, in addition to positive self-regulation. It established negative regulation with the Stxbp3a gene in both directions (Tacc1 $\leftrightarrow$ Stxbp3a) and positively regulated the Cic gene. Due to its positively regulated profile and biological function, this gene node represents an important candidate for a role in thymus/thymocyte development. 
4) Finally, Prrg2 was also identified as a gene node, which was negatively regulated by five (Itm2b, transcribed locus ID 640711, Stxbp3a, Triobp and Gosr2) of the eight gene nodes in this phase and also exhibited self-negative regulation. However, it positively regulated the Tacc1 node.

Taken together, these findings indicate that thymus ontogeny (14-17 days of gestation) features dynamic gene networks, involving pathways implicated in cell signaling and protein transport, including $\mathrm{T}$ cell receptor chains towards the cell membrane.

However, is important to consider that the networks reconstructed in this study are the result of specialized statistical microarray data analysis. Further investigations are necessary to determine their precise molecular mechanisms, i.e. involvement of RNA-RNA or DNA-RNA associations controlling the networks.

The probabilistic gene interactions observed in this work open new perspective for further molecular/biochemical approaches to confirm the role of genetic cascades in thymus development.

\section{Acknowledgements}

This study was funded by the Fundação de Amparo à Pesquisa do Estado de São Paulo (FAPESP) and the Conselho Nacional de Desenvolvimento Científico e Tecnológico (CNPq). The cDNA clones used for preparing the microarrays were kindly ceded by Dr. Catherine Nguyen (INSERM, URM 206, Marseille, France). We thank Guilherme Liberato Silva for help and discussions. 


\section{References}

1. Anderson G, Moore NC, Owen JJT, Jenkinson EJ (1996) Cellular interactions in thymocyte development. Annu Rev Immunol 14:73-99

2. Anderson G, Jenkinson EJ (2001) Lymphostromal interactions in thymic development and function. Nature Rev. Immunol. 1: 31-40

3. Kishimoto H, Sprent J, (1999) Several different cell surface molecules control negative selection of medullary thymocytes. J Exp Med 190: 65-73

4. Klein L, Kyewski B (2000) Self-antigen presentation by thymic stromal cells: a subtle division of labor. Curr Opin Immunol 12: 179-186

5. Kyewski B, Derbinski J (2004) Self-representation in the thymus: an extended view. Nat Rev Immunol 4: 688-698

6. Puthier D, Joly F, Irla M, Saade M, Victorero G, Loriod B, Nguyen C (2004) A general survey of thymocyte differentiation by transcriptional analysis of knockout mouse models. J Immunol 173: 6109-6118

7. Magalhães DA, Macedo C, Junta CM, Mello SS, Marques MM, Cardoso RS, Sakamoto-Hojo ET, Donadi EA, Passos GA (2005) Hybridization signatures during thymus ontogeny reveals modulation of genes coding for T-cell signaling proteins. Mol. Immunol. 42: 1043-1048

8. Cardoso RS, Junta CM, Macedo C, Magalhães DA, Silveira EL, Paula MO, Marques MM, Mello SS, Zarate-Blades CR, Nguyen C, Houlgatte, Donadi EA, Sakamoto-Hojo ET, Passos GA (2006) Hybridization signatures of gammairradiated murine fetal thymus organ culture (FTOC) reveal modulation of genes associated with T-cell receptor $\mathrm{V}(\mathrm{D}) \mathrm{J}$ recombination and DNA repair. Mol Immunol 43: 464-472

9. Eisen MB, Spellmam PT, Brown PO, Botstein D (1998) Cluster analysis and display of genome-wide expression patterns. Proc Natl Acad Sci USA 95: 14863-14868

10. Tusher VG, Tibshirani R, Chu G (2001) Significance analysis of microarrays applied to ionizing radiation response. Proc Natl Acad Sci USA 98: 5126-5121

11. Sousa-Cardoso $R$, Magalhães DA, Baião $A M$, Junta $C M$, Macedo $C$, Marques MM, Sakamoto-Hojo ET, Donadi EA, Passos GA (2006) Onset of promiscuous gene expression in fetal thymus organ culture. Immunology 119: 369-375

12. Wu CC, Huang HC, Juan HF, Chen ST (2004) GeneNetwork: An interactive tool for reconstruction of genetic network using microarray data. Bioinformatics 20: $3691-3693$

13. Schatz DG (2004) V(D)J recombination. Immunol Rev 200: 5-11 
14. Kishimoto H, Sprent J (2000) The thymus and negative selection. Immunol. Res 21: 315-323

15. Ghendler Y, Hussey RE, Witte T, Mizoguchi E, Clayton LK, Bhan AK, Koyasu S, Chang HC, Reinherz EL (1997) Double-positive T cell receptor (high) thymocytes are resistant to peptide/major histocompatibility complex ligand induced negative selection. Eur J Immunol 27: 2279-2289

16. Shortman K, Wu L (1996) Early T lymphocytes progenitors. Annu Rev Immunol 14: 29-47

17. Junta CM, Passos GAS (1998) Emergence of TCR alpha/beta V(D)J recombination and transcription during ontogeny of inbred mouse strains. Mol Cell Biochem 187: 67-72

18. Macedo C, Junta CM, Passos GAS (1999) Onset of T-cell receptor VBeta8.1 and DBeta2.1 V(D)J recombination and transcription during ontogeny of inbred mouse strains. Immunol Lett 69: 371-373

19. Espanhol AR, Macedo C, Junta CM, Cardoso RS, Victorero G, Loriod B, Nguyen C, Jordan B, Passos GA (2003) Gene expression profiling during thymus ontogeny and its association with TCRVbeta8.1-Dbeta2.1 rearrangements of inbred mouse strains. Mol Cell Biochem 252: 223-228

20. DeRyckere D, Mann DL, DeGregori J (2003) Characterization of transcriptional regulation during negative selection in vivo. J Immunol 171: 802-811

21. Hoffmann R, Bruno L, Seidl T, Rolink A, Melchers F (2003) Rules for gene usage inferred from a comparison of large-scale gene expression profiles of $T$ and B lymphocytes development. J Immunol 170: 1339-1353

22. Schmitz I, Clayton LK, Reinherz EL (2003) Gene expression analysis of thymocyte selection in vivo. Int Immunol 15: 1237-1248

23. Rugh R (1968) The mouse. Its reproduction and development. First Ed. Burgess Publishing Company. Edina, MN, USA.

24. Nguyen C, Rocha D, Granjeaud S, Baldit M, Bernard K, Naquet P, Jordan BR (1995) Differential gene expression in murine thymus assayed by quantitative hybridization of arrayed cDNA clones. Genomics 29: 207-215

25. Bertucci F, Houlgatte R, Granjeaud S, Nasser V, Loriod B, Beaudoing E, Hingamp P, Jacquemier J, Viens P, Birnbaum D (2002) Prognosis of breast cancer and gene expression profiling using DNA arrays. Ann N Y Acad Sci 975: $217-231$

26. Verdeil G, Puthier D, Nguyen C, Schmitt-Verhulst AM, Auphan-Anezin N (2002) Gene profiling approach to establish the molecular bases for partial versus full activation of naïve CD8 T lymphocytes Ann N Y Acad Sci 975: 68-76 
27. Honore P, Granjeaud S, Tagett R, Deraco S, Beaudoing E, Rougemont J, Debono S, Hingamp P (2006) MicroArray facility: a laboratory information management system with extended support for nylon based technologies. BMC Genomics 7: 240

28. Quackenbush J (2002) Microarray data normalization and transformation. Nature Genetics 32: 496-501

29. Basso K, Margolin AA, Stolovitzky G, Klein U, Dalla-Favera R, Califano A (2005) Reverse engineering of regulatory networks in human B cells. Nat Genet 37: $382-390$

30. Margolin A, Nemenman I, Basso K, Wiggins C, Stolovitzky G, Della Favera R, Califano A (2006) Aracne: an algorithm for the reconstruction of gene regulatory networks in a mammalian cellular context. BMC Bioinformatics S1

31. Gardner T, di Bernardo D, Lorenz D, Collins J (2003) Infering genetic networks and identifying compound mode of action via expression profiling. Science 301: 102-105

32. Di Bernardo D, Thomson M, Gardner T, Chobot S, Eastwood E, Wojtovich A, Elliott S, Schaus S, Collins J (2005) Chemogenomic profiling on a genomewide scale using reverse-engineered gene networks. Nat. Biotechnol. 23; 377383

33. Bansal M, Della Gatta G, di Bernardo D (2006) Inference of gene regulatory networks and compound mode of action from time course gene expression profiles. Bioinformatics 22: 815-822

34. Yu J, Smith VA, Wang PP, Hartemink AJ, Jarvis ED (2004) Advances to Bayesian network inference for generating causal networks from observational biological data. Bioinformatics 20: 3594-3603

35. Soinov LA, Krestyaninova MA, Brazma A (2003) Towards reconstruction of gene networks from expression data by supervised learning. Genome Biol. 4(1): R6.1-R6.10

36. Faith JJ, Hayete B, Thaden JT et al (2007) Large-scale mapping and validation of Escherichia coli transcriptional regulation from a compendium of expression profiles. Plos Biology 5: 54-66

37. Sandmann T, Girardot C, Brehme M et al (2007) A core transcriptional network for early mesoderm development in Drosophila melanogaster. Genes Develop 21: 436-449

38. Takaku T, Ohyashiki JH, Zhang Y, Ohyashikik K (2005) Estimating immunoregulatory gene networks in human herpesvirus type 6-infected T cells. Biochem Biophys Res Commun 336 : 469-477

39. Takasaki I, Takarada S, Fukuchi M, Yasuda M, Tsuda M, Tabuchi Y (2007) Identification of genetic networks involved in the cell growth arrest and 
proliferation of a rat astrocyte cell line RCG-12. J. Cell. Biochem. (in press, DOI : 10.1002/jcb.21369)

40. de La Fuente A, Brazhnik P, Mendes $P$ (2002) Linking the genes: inferring quantitative gene networks from microarray data. Trends Genet 18: 395-398

41. Feske S, Giltnane J, Dolmetsch R, Staudt LM, Rao A (2001) Gene regulation mediated by calcium signals in T lymphocytes. Nat Immunol 2: 316324

42. Feske S, Okamura H, Hogan PG, Rao A (2003) Ca+/calcineurin signalling in cells of the immune system. Biochem Biophys Res Commun 311: 11171122

43. Heissmeyer V, Macian F, Im SH, Varma R, Feske S, Venuprasad K, Gu H, Liu YC, Dustin ML, Rao A (2004) Calcineurin imposes T cell unresponsiveness through targeted proteolysis of signaling proteins. Nat Immunol 5: 255-265

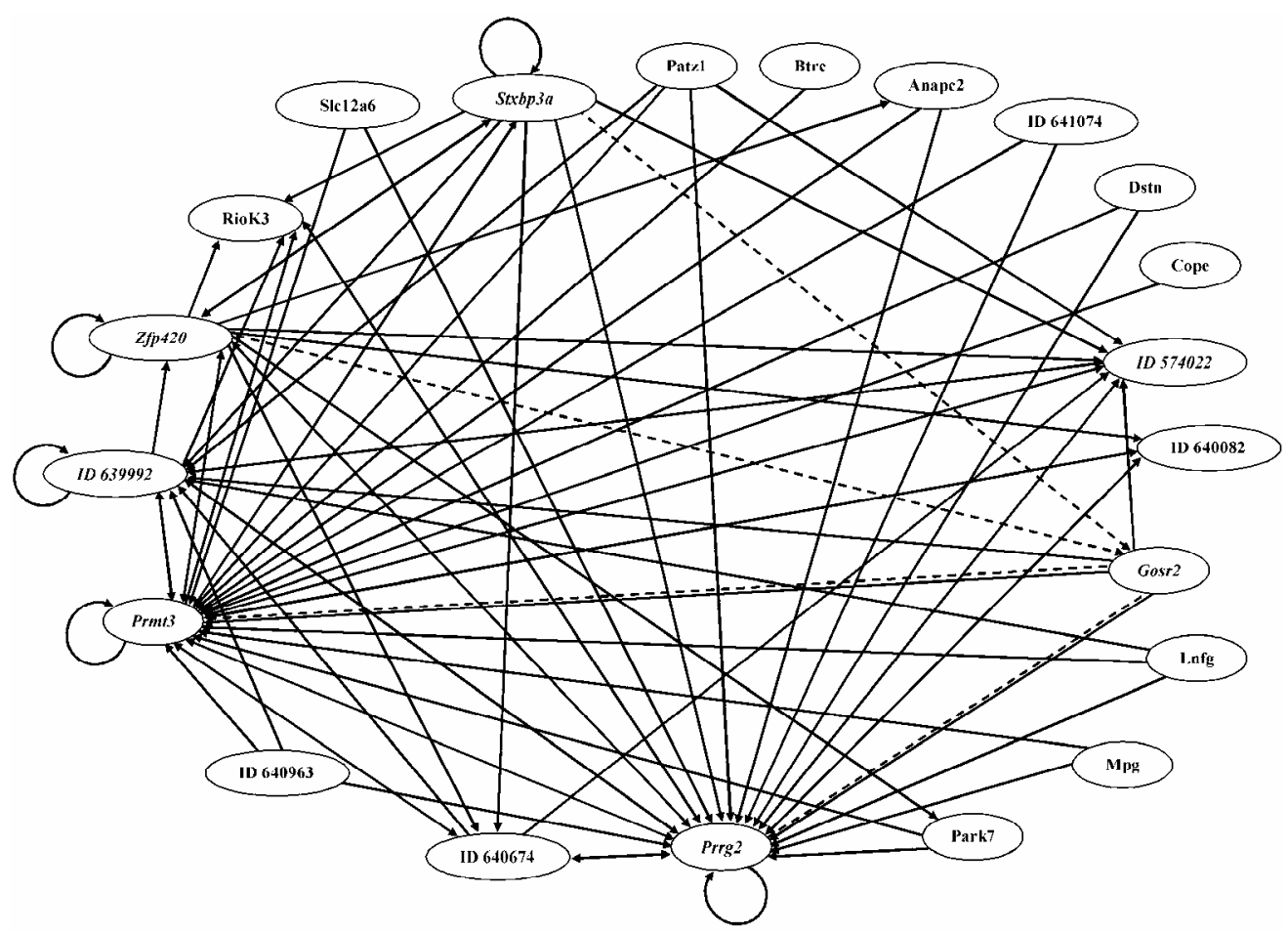



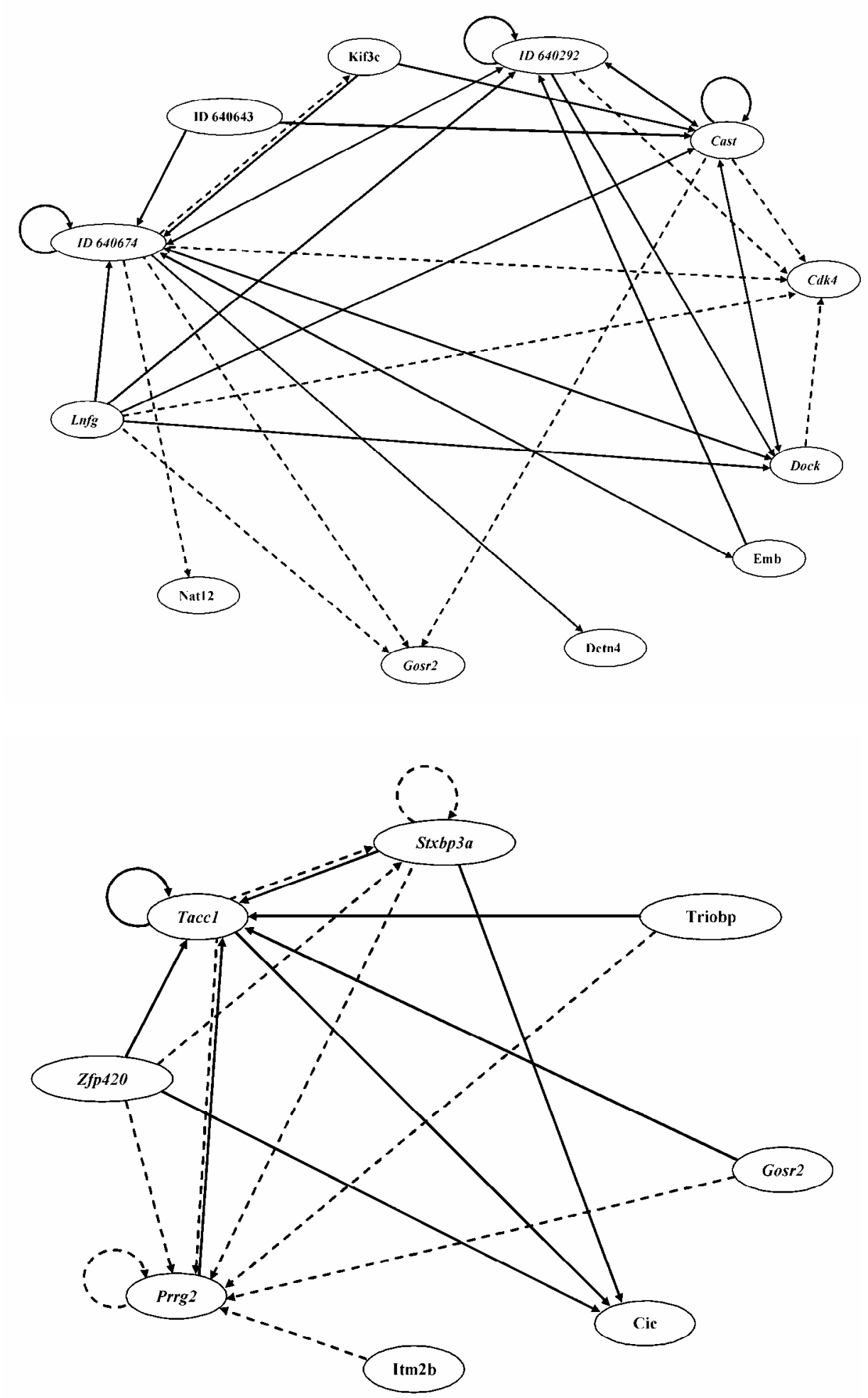

Figure legend

Figure 1. Gene networks during thymus development reconstructed from cDNA microarray gene expression data. A) 14 vs 15 days p.c. B) 14 vs 16 days p.c. and C) 14 vs 17 days p.c. The italicized symbols represent those discussed gene nodes. 


\section{Onset of promiscuous gene expression in murine fetal thymus organ culture}

Renato Sousa Cardoso, ${ }^{1 \star}$ Danielle A. R. Magalhães, ${ }^{1 \star}$ Ana Maria T. Baião, ${ }^{1 \star}$ Cristina Moraes Junta, ${ }^{1}$ Claudia Macedo, ${ }^{1}$ Márcia M. C. Marques, ${ }^{1}$ Elza Tiemi SakamotoHojo, ${ }^{2,3}$ Eduardo A. Donadi ${ }^{4}$ and Geraldo A. S. Passos ${ }^{1,5}$

${ }^{1}$ Molecular Immunogenetics Group, Department of Genetics, Faculty of Medicine,

${ }^{2}$ Laboratory of Cytogenetics and Mutagenesis Department of Genetics, Faculty of Medicine, ${ }^{3}$ Department of Biology (FFCLRP), ${ }^{4}$ Department of Medicine, Faculty of Medicine, and ${ }^{5}$ Discipline of Genetics (DMEF), Faculty of Dentistry, University of São Paulo, Ribeirão Preto, SP, Brazil

doi:10.1111/j.1365-2567.2006.02441.x Received 4 January 2006; revised 27 June 2006; accepted 28 June 2006.

${ }^{\star}$ These authors contributed equally to this work.

Correspondence: Dr Geraldo A. S. Passos, Molecular Immunogenetics Group,

Department of Genetics, Faculty of Medicine, 14040-900, Ribeirão Preto, SP, Brazil.

Email: passos@rge.fmrp.usp.br

Senior author: Dr Geraldo A. S. Passos

\begin{abstract}
Summary
T-cell differentiation and induction of tolerance to self-antigens occurs mainly in the thymus. Thymic stromal cells, specifically medullary thymic epithelial cells, express a diverse set of genes encoding parenchymal organ-specific proteins. This phenomenon has been termed promiscuous gene expression (PGE) and has been implicated in preventing organspecific autoimmunity by inducing T-cell tolerance to self antigens. Early thymopoiesis and the critical factors involved in T-cell differentiation can be reproduced in vitro by murine fetal thymus organ culture (FTOC), which mimics the natural thymic microenvironment. To evaluate the occurrence of PGE in FTOC, gene expression profiling during in vitro thymic development in $\mathrm{BALB} / \mathrm{c}$ mice was performed using a set of nylon cDNA microarrays containing 9216 sequences. The statistical analysis of the microarray data (SAM program) revealed the temporal repression and induction of 57 parenchymal and seven lymphoid organ-specific genes. Most of the genes analysed are repressed during early thymic development (1517 days post-coitum). The expression of the autoimmune regulator (AIRE) gene at 16 days post-coitum marks the onset of PGE. This precedes the induction of parenchymal organ genes during the late developmental phase at 20 days post-coitum. The mechanism of T-cell tolerance induction begins during fetal development and continues into adulthood. Our findings are significant because they show a fine demarcation of PGE onset, which plays a central role in induction of T-cell tolerance.
\end{abstract}

Keywords: cDNA microarray; fetal thymus organ culture; promiscuous gene expression; thymus; T-cell tolerance

\section{Introduction}

The thymus is the key primary lymphoid organ that is mainly involved in the progressive differentiation of thymocytes to mature $\mathrm{T}$ cells in which all developmental stages are distinguishable by their expression of a combination of clusters of differentiation (CD) cell-surface markers. Studies with freshly obtained fetal thymus allowed for the demarcation of T-cell receptor $\beta \mathrm{V}(\mathrm{D}) \mathrm{J}$ recombination during in vivo thymus ontogeny among different inbred mouse strains; this contributed to the revealing of the effect of the genetic background on T-cell development. ${ }^{1-3}$ The control of gene expression during the development of this organ has gained priority among several research groups, including our own, leading to the identification of candidate genes involved in thymopoiesis. Using the cDNA microarray method, a dozen expressed sequence tags have been found that are modulated during the in vivo development of the thymus. ${ }^{4}$ Using the same kind of analysis, the in vivo modulation of several cell-signalling genes was identified, including those of the calcium cascade pathway, which is important for individual stages of T-cell maturation and the control of anergy during murine thymus ontogeny. ${ }^{5}$

Meanwhile, a better understanding of the central tolerance mechanism, that is, all the mechanisms by which $\mathrm{T}$ cells contribute to self-tolerance by intrathymic recognition of self-antigens, emerged from evidence that 
tissue-specific antigens are expressed in the thymus and contribute to the selection of the T-cell repertoire. These tissue-specific antigens are expressed as a normal physiological property of thymic epithelial cells (TECs). ${ }^{6}$ This phenomenon was termed promiscuous gene expression (PGE), which includes self antigens that represent most of the parenchymal organs. ${ }^{7-14}$ Evidence of PGE in the thymus is causing a reversal in our understanding of central tolerance, allowing for an unorthodox conception of the possible mechanism of self-non-self discrimination. ${ }^{15,16}$

The initial evidence for promiscuously expressed genes was biased towards antigens involved in autoimmune reactions, such as insulin, acetylcholine receptor or myelin basic protein. Today it is recognized that rather than being selective, the set of expressed genes is as broad as possible, estimated to include up to $5-10 \%$ of all currently known mouse genes. ${ }^{9}$ Thus, the main implication of this heterogeneous gene expression in the thymus is associated with maintenance of the immunological homeostasis in the body, controlling pathogenic autoimmune reactions.

Studies on thymus gene expression in the broadest aspect, including PGE, are normally designed to be performed immediately using samples collected by surgery, which must reflect the short-term in vivo situation.

Nevertheless, fetal thymus organ culture (FTOC), introduced by DeLuca's group, ${ }^{17}$ which is based on the use of early fetal thymus tissue, preserves the original architecture of the thymus, with its cellularity formed of stromal TECs and homogeneous thymocyte population doublenegative cells. This is a singular, powerful culture model system reproducing intrathymic T-cell development in vivo, making it easier to study the candidate genes implicated in normal thymus development. Using the cDNA microarray method, our group recently showed the modulation of gene expression in murine FTOCs at the transcriptome level and revealed an overlap between genes associated with $\mathrm{T}$-cell receptor $\mathrm{V}(\mathrm{D}) \mathrm{J}$ recombination and DNA repair. We showed that the association of FTOC and cDNA microarray technology allows sufficient accuracy to uncover the participation of essential genes implicated in thymus development. ${ }^{18}$

In the present study, cDNA microarrays were employed to observe the onset of PGE during the in vitro development of murine thymus in FTOCs. Comparing the time of thymus gestation as a result of fetal age and culture duration, it was possible to discover the onset of gene induction, representing 57 different parenchymal and seven lymphoid organs. Some coded proteins are considered to be tissue-specific antigens, thus indicating that FTOCs reproduce promiscuous gene expression.

The FTOC transcriptome profiling was assessed using a set of six nylon cDNA microarrays containing a total of 9216 IMAGE thymus sequences. PGE was identified on the basis of gene expression data for different parenchymal organs. To our knowledge, these findings represent the first demonstration of the temporal beginning of PGE in murine FTOC. Moreover, the importance of this event is associated with the fact that this model system could be a useful tool for testing cytokines, RNA interference or other compounds that directly control gene expression in the thymus, as possible modulators of PGE.

\section{Material and methods}

\section{FTOCs and total RNA preparation}

$\mathrm{BALB} / \mathrm{c}$ mice were bred in an isolator with $0 \cdot 45-\mu \mathrm{m}$ poresize air filtered in our own breeding facility. To obtain timed pregnancies, the mice were mated and the day when the vaginal plug was observed at 7:00 hr was considered to be day zero of gestation post-coitum (p.c.). The pregnant mice were killed by ether inhalation and the fetuses were collected via surgery of the uterus. The p.c. age of the fetuses was confirmed by the morphological characteristics of each developmental phase. ${ }^{18,19}$ The thymi were removed from the fetuses under a stereomicroscope and cultured according to the organ culture technique previously described. ${ }^{17}$

Briefly, the organs were dissected and cleaned from the adjacent tissue and placed on the surface of Millipore filters $(0.45 \mu \mathrm{m}$ pore size $)$ pre-embedded with culture medium. These filters were supported on plastic grids in $2 \mathrm{ml}$ Dulbecco's modified Eagle's medium/HAM F-10 culture medium (Gibco, Gaithersburg, MD, USA) supplemented with $20 \%$ heat inactivated fetal bovine serum (Biobrás, Montes Claros, MG, Brazil) in 24-well tissue culture plates. The medium was also supplemented with $100 \mu \mathrm{g} / \mathrm{ml}$ streptomycin, $250 \mathrm{U} / \mathrm{ml}$ penicillin, $10 \mu \mathrm{g} / \mathrm{ml}$ gentamicin, $1 \mathrm{~mm}$ sodium pyruvate, $20 \mu \mathrm{M} 2$-mercaptoethanol and $3.4 \mathrm{~g} / \mathrm{l}$ sodium bicarbonate. The incubation time of the organ culture varied from 2 to 5 days at $37^{\circ}$ in a $5 \% \mathrm{CO}_{2}$ incubator.

Thymi were dissected from fetuses obtained at 13, 14 and 15 days of gestation and cultured for 2 days, so mimicking 15, 16 and 17 days p.c. of in vivo development, respectively. Thymi from 15-day p.c. fetuses were also cultured for 5 days, mimicking the 20th day of in vivo development, and in this case, the culture medium was changed on the third day of incubation.

To evaluate the viability of FTOCs, three randomly selected thymi from each group were used for the single cell suspension preparations, which were separately stained with acridine orange $(100 \mu \mathrm{g} / \mathrm{ml})$ or with ethidium bromide $(100 \mu \mathrm{g} / \mathrm{ml})$ and analysed on an Axiophot II fluorescence microscope (Carl Zeiss, Oberkochen, Germany) to evaluate the frequency of apoptosis and necrosis, respectively. Total RNA samples were prepared from FTOCs using Trizol ${ }^{\circledR}$ reagent according to the manufacturer's instructions (Invitrogen, Carlsbad, CA, USA). 


\section{cDNA microarray method}

A set of six microarrays were used containing a total of 9216 cDNA sequences (1536 sequences each) in the form of polymerase chain reaction (PCR) products, spotted in duplicate on $2.5 \times 7.5 \mathrm{~cm}$ Hybond $\mathrm{N}+$ nylon membranes (GE Healthcare, Amersham, UK). The arrays were prepared in our laboratory using a Generation III Array Spotter (Amersham Biosciences-Molecular Dynamics, Sunnyvale, CA, USA).

Mouse thymus expressed sequence tag cDNA clones were obtained from the Soares thymus 2NbMT normalized library, prepared from the thymus of a C57BL/6J 4-week-old male mouse, and available from the IMAGE Consortium (http://image.llnl.gov/image/html/iresources. shtml) and from the RZPD Deutsches Resourcenzentrum für Genomforschung GmbH (http://www.rzpd.de).

The cDNA inserts were homogeneous in size (near $1 \mathrm{~kb}$ ), cloned in three vectors (pT7T3D, pBluescript and Lafmid) and were amplified in 384- or 96-well plates using vector-PCR amplification with the following primers, which recognize the three vectors: LBP $1 S$ GTGGAATTGTGAGCGGATACC forward and LBP 1AS GCAAGGCGATTAAGTTGG reverse. This set of cDNAs included sequences of some known autoantigens, such as small nuclear ribonucleoprotein SMD1, lupus Ku protein p70, p80 and p86 and PM-SCL; the full list of cDNA sequences used to prepare the microarrays can be retrieved online at http://rge.fmrp.usp.br/passos/mtb_library.

The membranes were first hybridized with LBP 1AS $\left[\gamma_{-}{ }^{33} \mathrm{P}\right] \mathrm{dCTP}-$ labelled oligonucleotide (vector hybridization). Quantification of the signals obtained allowed for the estimation of the amount of cDNA insert fixed in each spot. After stripping, the membranes were used for hybridization with cDNA complex probes (sample hybridization). The characterization of each cDNA sequence was updated using the ELOGE ${ }^{\circledR}$ (Ipsogen, Marseille, France, http://www.ipsogen. fr) software, which runs on our local server and links each clone ID with the genome data banks (http://genomewww5.stanford.edu/cgi-bin/source/sourceSearch), providing information such as DNA and protein sequences, biological and molecular functions and chromosomal location.

\section{Complex cDNA probe preparation and hybridization}

In this study, we refer to the radioactive cDNA originated from the thymus RNA samples (FTOCs) as complex probe and to the PCR product originated from the clones and deposited on nylon microarrays as target.

The ${ }^{33} \mathrm{P}$-labelled cDNA complex probes were prepared by reverse transcription of $10 \mu \mathrm{g}$ thymus total RNA using oligo-dT(12-18) as a primer; $100 \mu \mathrm{l}{ }^{33} \mathrm{P}-\mathrm{cDNA}$ complex probe containing $30-50$ million counts per minute was hybridized with nylon microarrays as previously described. $^{20-22}$

\section{cDNA microarray image acquisition}

Imaging plates and a phosphor imager apparatus (Packard Phosphor Imager, model Cyclone, Packard Instruments, Downers Grove, IL, USA) were used to capture the hybridization signals and the BZScan software ${ }^{23}$ was used to quantify the signals with local background subtraction, whose spots were matched with a template grid. The ratio between vector probe hybridization values and complex probe hybridization values for each spot was used as a reference normalization value. Total intensity normalization was also employed, using the median expression value. ${ }^{24}$

\section{Significance analysis of microarray data}

The gene expression data analysed here were obtained from six independent determinations for each day of fetal development in FTOC. The SAM method ${ }^{25}$ (Significance Analysis of Microarrays, available at http://www.stat. stanford.edu/ tibs/SAM/index.html) was used to analyse significant variations in gene expression. This method is based on $t$-test statistics, specially modified for high throughput analysis. The significant variations in the gene expression of developing thymus in FTOCs were compared using the 15 -day p.c. as reference (15 versus 16,15 versus 17 and 15 versus 20 days of development). In this study, only those genes presenting a two-fold change of expression (either repressed or induced) and a gene error chance ( $q$-value) equal to 0.01 (see Supplementary Table S1) were considered.

\section{Determination of PGE in the thymus}

PGE was identified on the basis of data from microarray analysis of the different mouse organs using combined information from the public database GNF Gene Expression Atlas $^{26}$ (http://symatlas.gnf.org/SymAtlas). This data bank shows gene expression in more than 60 mouse tissues/organs, as assessed by gene array analysis using Affymetrics microarrays. Data information includes GenBank accession, chromosomal location and the molecular/biological function of each gene analysed (Table S1).

In this study, only the promiscuous genes of which the expression was detected in different organs or tissues, besides the thymus, and of which the expression levels were greater than median in relation to all other organs which appear in the GNF Atlas were considered. The modulation of transcription levels (repression or induction) of these genes was evaluated during FTOC development.

\section{Semi-quantitative reverse transcription-PCR} (SQ RT-PCR)

The zinc finger protein 369 gene (ZNF 369; acc NM_178364, clone ID 573600) that was found to be 
induced in the microarray experiments and the AIRE gene (acc NM_009646) were tested by SQ RT-PCR; $1 \mu \mathrm{g}$ total RNA from each developmental phase in FTOC was copied to cDNA by reverse transcription using oligo-dT(12-18) as a primer. One microlitre of successive dilutions of the cDNA $(1: 2$ to $1: 128)$ were used as a PCR template. PCRs were performed in a final volume of $25 \mu \mathrm{l}$ containing $100 \mu \mathrm{M}$ each dNTP, $1 \mu \mathrm{M}$ each primer and $1 \mathrm{U}$ Taq DNA polymerase (Amersham Biosciences).

The amplification protocol for the ZNF 369 and AIRE genes assayed was as follows; one cycle at $94^{\circ}$ for $5 \mathrm{~min}$, 30 cycles of $94^{\circ}$ for $1 \mathrm{~min}, 55^{\circ}$ for $1 \mathrm{~min}$, then $72^{\circ}$ for $1 \mathrm{~min}$, and then one cycle at $72^{\circ}$ for $10 \mathrm{~min}$ then $4^{\circ}$ for $10 \mathrm{~min}$. The amplification was terminated with a final incubation step at $72^{\circ}$ for $10 \mathrm{~min}$.

Aliquots of the PCR products were mixed with $1 \mu \mathrm{l}$ of a diluted solution of ethidium bromide, resolved on $2 \%$ agarose gel electrophoresis using $1 \times$ TAE buffer. The gels were visualized on a UV transilluminator and the images were captured using a digital camera.

The PCR primers were identified using the PRIMER 3 software (http://frodo.wi.mit.edu/cgi-bin/primer3/primer3_ www.cgi) on the cDNA sequences retrieved from GenBank (http://www.ncbi.nlm.nih.gov) for each gene. The forward and reverse sequences are given in the $5^{\prime}$ to $3^{\prime}$ orientation; ZNF 369 (clone ID 573600, GenBank acc NM_178364) (GGGAGGACCTTATGTGTGT and GGGGCTCTCCTT ATCCAAAAG) and the autoimmune regulator gene, AIRE (GenBank acc NM_009646), although not included in the microarrays, was also assayed with the following primers (CATCCTGGATTTCTGGAGGA and GCTCTTTGAGGC CAGAGTTG).

\section{Results}

\section{Genes differentially expressed during FTOC development}

To identify significant changes in gene expression during fetal development in FTOCs, the early thymus at 15 days was compared with those observed on the subsequent days (15 versus 16,15 versus 17 and 15 versus 20 days p.c. FTOC). A scatter plot of the observed relative difference $d(i)$ against the expected relative difference $d_{E}(i)$ was used, as shown by the SAM program.

Most of the 9216 sequences tested presented $d(i) \cong d_{E}(i)$, indicating that their expression pattern remained unchanged; however, some genes were significantly repressed (154 genes) or induced (38 genes) during FTOC development (Fig. 1).

Interestingly the induction of the 38 genes that include representation of parenchymal organs in the thymus, thus characterizing PGE, was observed at late FTOC (20 days p.c.) (Table S1).

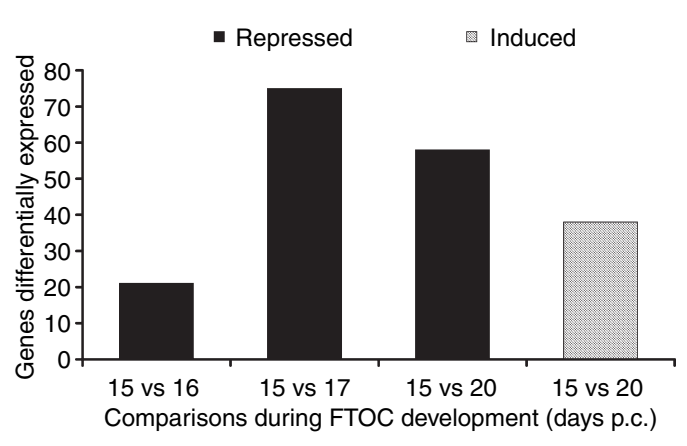

Figure 1. Differential gene expression during the development of FTOC showing that induction of tissue-specific genes emerges at 20 days. Staging corresponds to development of fetal thymus in culture; 15 days FTOC $=13$ days gestation thymus plus 2 days in FTOC.

\section{Gene expression assessed by SQ RT-PCR}

The ZNF 369 gene (acc NM_178364) was selected to confirm the respective result obtained with the cDNA microarray. SQ RT-PCR evaluation confirmed that this gene was induced at 20 days p.c. FTOC (Fig. 2a). Moreover, the AIRE gene (acc NM_009646) began its expression at 16 days p.c. FTOC (Fig. 2b).

\section{Parenchymal organ representation in the thymus}

The 38 genes identified as significantly induced at 20 days p.c. in FTOC were assigned to 57 parenchymal and seven lymphoid organs according to their predominant expression, which were subgrouped in 17 systems. Interestingly, central nervous and reproductive systems and glands are the predominant parenchymal organs represented in the thymus at this phase of development, followed by the lymphoid system (Fig. 3). Four genes; small nuclear ribonucleoprotein D1, acc NM_009226; CD27 antigen, acc L24495; Riken cDNA 1110065L07, acc AA119642; and D-amino-acid oxidase, acc AI447515; code for tissuespecific antigen proteins, because they are expressed in only five or six tissues (Table S1).

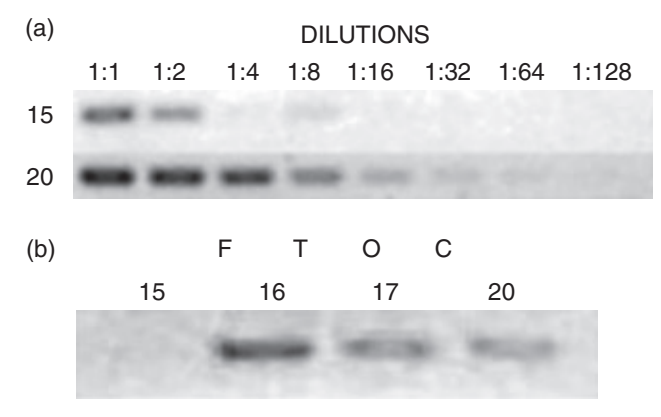

Figure 2. Semi-quantitative reverse transcription-PCR. Confirmation of $Z N F$ gene as induced at 20 days FTOC (a) and emergence of AIRE gene expression at 16 days FTOC (b). 


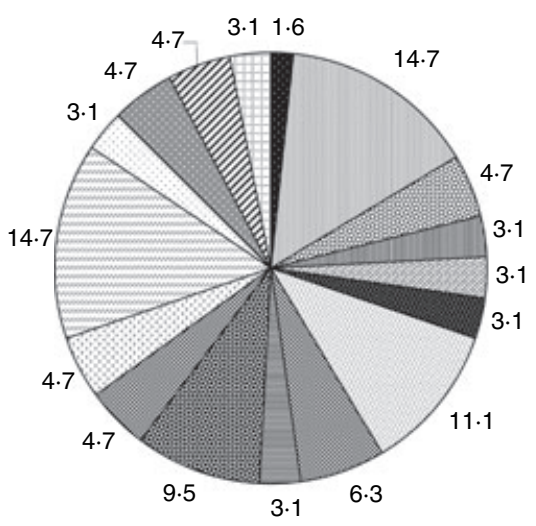

- Circulatory

- Central Nervous

a Digestive

- Epidermis/Skin

a Eyes

- Fat tissue

ธ Glands

- Intestines

- Locomotory

- Lymphoid

- Muscles

匹 Peripheral Nervous

$\square$ Reproductive

$\square$ Respiratory

- Sensory Organs

a Stem cells

u Urinary

Figure 3. Representation of tissue/organ system-specific gene expression in 20 days FTOC.

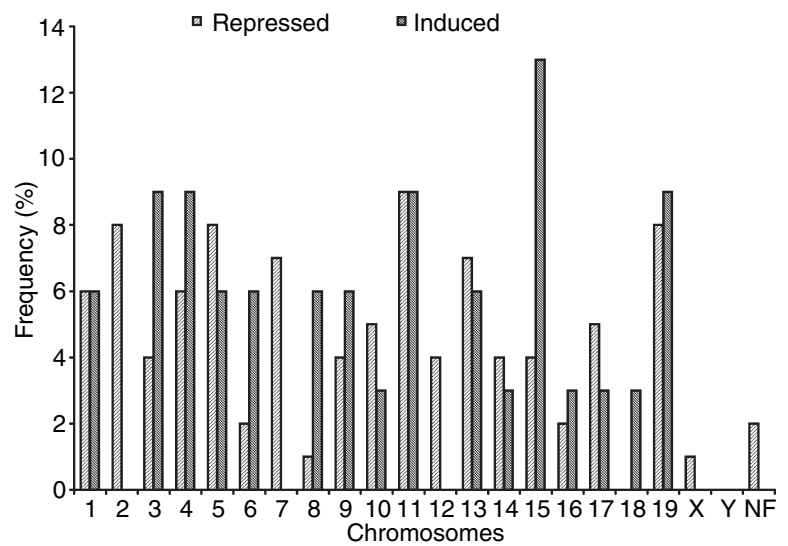

Figure 4. Chromosomal distribution of the repressed and induced genes considering all FTOC development (15-20 days).

NF, not found.

\section{Chromosomal location of differentially expressed genes}

The genomic distribution of the 192 genes modulated (repressed or induced) during the 5 days of FTOC development allowed for the co-ordinated expression of organizing chromosomal clusters.

Figure 4 shows the frequency distribution of the repressed and induced genes among chromosomes. Taking all the developmental phases together, the number of repressed genes (154) was greater than that of induced genes (38). All chromosomes, except $\mathrm{Y}$, harboured differentially expressed genes, with a slightly biased distribution on chromosomes 2, 5, 11 and 19 for repressed genes and on chromosomes 3, 4, 11, 15 and 19 for induced genes.

\section{Discussion}

PGE in the thymus is a complex phenomenon observed in humans and mice, which is exhibited by TECs (mTECs) and involves $5-10 \%$ of all known genes of these species. This process is a guarantee of self-representation of most parenchymal tissues and organs during the central tolerance of $\mathrm{T}$ cells.

Using PCR, Derbinski's group previously demonstrated that the expression of five tissue-specific genes, such as thyroglobulin, CRP, GAD67, insulin and albumin, was detectable only in mTECs purified from ex vivo thymic tissue at embryonic day 15 (E15). ${ }^{7}$

Accordingly, the complexity of PGE increases in, from cTECs to immature mTECs to mature CD $80^{\text {hi }}$ mTECs. These different gene pools are not complementary, but additive, that is, there is no apparent association between the respective molecular/biological functions of the genes in parenchymal organs. The significance of PGE in the thymus is associated with the central tolerance of $\mathrm{T}$ cells. $^{9-14}$

While PGE by mTECs was well documented by the authors cited above, many aspects of this phenomenon remain unexplored, for example, its evaluation in the thymus of autoimmune strains and/or knockout mice, its modulation by means of cytokines or other molecules interfering in gene expression, such as RNA interference, and its time-course during the ontogenetic development of the thymus.

Molecular characterization of PGE in the FTOC model system is a relevant approach in immunobiology, because the functional analysis of T-cell development has become possible after the introduction of techniques in which the thymic microenvironment is mimicked, such as FTOC. This method is based on the use of early fetal thymus tissue, which is composed of a homogeneous thymocyte population (double-negative cells).

In this study, the occurrence of PGE in vitro in FTOC is described for the first time. To evaluate whether PGE in this model system is a development-dependent phenomenon, we regarded the differential gene expression during ontogeny by comparing days of gestation (p.c.), as the most informative in the delineation of the gene pool. Use of the FTOC model system was chosen, rather than compare the changes in expression profiles in thymus tissue obtained at different gestational days, to approach three important aspects simultaneously. Since FTOC reproduces the in vivo thymus development, this model system represented a useful tool first, for the fine demarcation of PGE onset and, second, to demonstrate that PGE is a phenomenon that can be reproduced in vitro. The third aspect was a beneficial possibility of the FTOC model system, comparing the same pool of thymus tissue at day 15 with later time-points.

We demonstrated that PGE in FTOC, which is characterized by the overexpression of parenchymal organ and tissue-specific antigen genes, emerges at 20 days p.c. (Fig. 1). Since this in vitro organ culture mimicked the thymus gestation in vivo, including the maturation of $\mathrm{T}$ 
cells, ${ }^{18}$ these results strongly suggest that PGE is dependent on thymus maturation. The significance of these findings is associated with the timing of T-cell tolerance induction during ontogeny. T-cell receptor $\beta$ rearrangements emerge at 16 days p.c. in vivo and in FTOC in BALB/c mice. ${ }^{1-3,18}$

The early fetal thymus, by $13-15$ days p.c., is composed of homogeneous double-negative $\mathrm{CD}^{-} \mathrm{CD}^{-}$ T-cell precursors; however, by day 18 p.c. this population gradually acquires the CD4 marker resembling the adult CD4 ${ }^{\text {low }}$ precursor. ${ }^{26,27}$ These features allow for T-cell receptor-major histocompatibilty complex peptide recognition and enable the positive/negative selection of $\mathrm{T}$ cells in fetal thymus. Our evidence for the occurrence of PGE in late fetal thymus is associated with the timing of the molecular events of T-cell tolerance induction during ontogeny.

The data collected here were obtained using the cDNA microarray method, with the expression of the 9216 sequences analysed by the SAM algorithm. ${ }^{25}$ Considering 15 days p.c. FTOC as a reference, it was possible to make comparisons with the subsequent days of development. A statistically significant set of 154 repressed genes were found between 15 and 17 days p.c. and 38 genes were considered as overexpressed at 20 days p.c. FTOC, indicating the emergence of PGE (Table S1).

Moreover, these findings are important to the PGE differentiation model in the thymus and the concomitant increased $A I R E$ gene expression in the most mature mTECs. In the FTOC model system studied, AIRE gene expression begins at 16 days p.c., before a significant induction of parenchymal and tissue-specific antigen genes (Fig. 2b), suggesting that this gene could be associated with the control of the parenchymal organ gene expression observed. ${ }^{28}$

Although the experiments were not conducted with purified mTECs, this caused no problems regarding PGE detection in the thymus. To bypass this potential difficulty, a cDNA microarray method was used, including a dedicated statistical algorithm for data analysis (SAM algorithm), which presented sufficient accuracy to distinguish and quantify parenchymal organ gene expression originating from thymic epithelial cells, especially mTECs. ${ }^{8,9,13}$

The cDNA microarray data mining has permitted the virtual dissection of the mouse thymus into its principal cellular components by means of the identification of the specific cellular transcripts (mRNAs). ${ }^{29}$ These observations demonstrate the feasibility for the use of whole thymus as starting material in PGE studies.

Moreover, we selected a gene found in the microarray experiments (ZNF 369) that is representative of parenchymal organs, whose modulation in the expression was confirmed by SQ-RT-PCR (Fig. 2a).

In agreement with previous observations, ${ }^{13}$ the molecular/biological function of promiscuously expressed genes found in the present model system showed no interrelationship (Table S1).

Regarding the chromosomal localization of the repressed and induced genes, no important preferential distribution was identified. All chromosomes harbour promiscuously expressed genes with a slightly biased distribution on chromosomes 2, 5, 11 and 19 among the repressed genes and on chromosomes 3, 4, 11, 15 and 19 among the induced genes. The exceptions were chromosome $\mathrm{Y}$, on which no repressed or induced genes were identified, and chromosome 2, on which no induced genes were positioned (Fig. 4).

This feature of random PGE distribution in the genome strongly suggests an uncommon model of gene regulation found in the thymus, which requires further investigation, including the elucidation of the molecular mechanism of the AIRE gene action.

The model system presented here was important to demonstrate that PGE is a differentially controlled phenomenon, ${ }^{9}$ beginning in BALB/c mice at 20 days p.c. (FTOC), and because this phenomenon can be reproduced in vitro, these findings raise the possibility of testing the induction of gene expression alteration caused by FTOC cytokine treatment or selected gene transfections that could modulate PGE. Recent evidence for a second thymus in mice ${ }^{30}$ increase the possibility of further research into their contribution to self-tolerance mechanisms, including determination of occurrence of the PGE in this organ.

\section{Acknowledgements}

This research was funded by the Brazilian agencies FAPESP (Fundação de Amparo à Pesquisa do Estado de São Paulo) through thematic project (99/12135-9) and doctorate fellowships to R.S.C., D.A.R.M., C.M.J., and M.M.C.M. and the $\mathrm{CNPq}$ (Conselho Nacional de Desenvolvimento Científico e Tecnológico) to C.M. The IMAGE cDNA library used was kindly ceded by Dr Catherine Nguyen of the Unité INSERM ERM 206, Marseille, France.

\section{References}

1 Junta CM, Passos GAS. Emergence of TCR $\alpha \beta$ V (D) J recombination and transcription during thymus ontogeny of inbred mouse strains. Mol Cell Biochem 1998; 187:67-72.

2 Macedo C, Junta CM, Passos GAS. Onset of T-cell receptor $\mathrm{V} \beta 8.1$ and $\mathrm{D} \beta 2.1, \mathrm{~V}(\mathrm{D}) \mathrm{J}$ recombination during thymus development of inbred mouse strains. Immunol Lett 1999, 69:371-3.

3 Espanhol AR, Macedo C, Junta CM, et al. Gene expression profiling during thymus ontogeny and its association with TRVB8DB2.1 rearrangements of inbred mouse strains. Mol Cell Biochem 2003; 252:223-8.

4 Espanhol AR, Cardoso RS, Junta CM, Victorero G, Loriod B, Nguyen C, Passos GAS. Large scale gene expression analysis of CBA/J mouse strain fetal thymus using cDNA-array hybridizations. Mol Cell Biochem 2004; 206:65-8. 
5 Magalhães DA, Macedo C, Junta CM, et al. Hybridization signatures during thymus ontogeny reveals modulation of genes coding for T-cell signaling proteins. Mol Immunol 2005; 42:1043-8.

6 Jolicoeur C, Hanahan D, Smith KM. T-cell tolerance toward a transgenic $\beta$-cell antigen and transcription of endogenous pancreatic genes in thymus. Proc Natl Acad Sci USA 1994; 91:6707-11.

7 Derbinski J, Schulte A, Kyewski B, Klein L. Promiscuous gene expression in medullary thymic epithelial cells mirrors the peripheral self. Nat Immunol 2001; 2:1032-9.

8 Gotter J, Brors B, Hergenhahn M, Kyewski B Medullary epithelial cells of the human thymus express a highly diverse selection of tissue-specific genes colocalized in chromosomal clusters. J Exp Med 2004; 199:155-66.

9 Kyewski B, Derbinski J. Self-representation in the thymus: an extended view. Nat Rev Immunol 2004; 4:688-98.

10 Sospedra M, Ferrer-Francesch X, Dominguez O, Juan M, Foz-Sala M, Pujol-Borrel R. Transcription of a broad range of self-antigens in human thymus suggests a role for central mechanisms in tolerance toward peripheral antigens. J Immunol 1998; 161:5918-29.

11 Bruno R, Sabater L, Sospedra M, Ferrer-Francesch X, Escudero D, Martínez-Cáceres E, Pujol-Borrel R. Multiple sclerosis candidate autoantigens except myelin oligodendrocyte glycoprotein are transcribed in the human thymus. Eur J Immunol 2002; 32:2737-47.

12 Bruno R, Sabater L, Tolosa E, et al. Different patterns of nicotinic acetylcholine receptor subunit transcription in human thymus. J Neuroimmunol 2004; 149:147-59.

13 Derbinski J, Gäbler J, Brors B, Tierling S, Jonnakuty S, Hergenhahn M, Peltonenh L, Walter J, Kyewski B. Promiscuous gene expression in thymic epithelial cells is regulated at multiple levels. J Exp Med 2005; 202:33-45.

14 Gallegos A, Bevan MJ. Central tolerance: good but imperfect. Immunol Rev 2006; 209:290-6.

15 Kyewski B, Derbinski J, Gotter J, Klein L. Promiscuous gene expression and central T-cell tolerance: more than meets the eye. Trends Immunol 2002; 23:364-71.

16 Mathis D, Benoist C. Back to central tolerance. Immunity 2004; 20:509-16.

17 DeLuca D, Bluestone JA, Schultz LD, Sharoow SO, Tatsumi Y. Programmed differentiation of murine thymocytes during fetal thymus organ culture. J Immunol Meth 1995; 178:13-29.

18 Cardoso RS, Junta CM, Macedo C, et al. Hybridization signatures of gamma-irradiated murine fetal thymus organ culture (FTOC) reveal modulation of genes associated with T-cell recep- tor $\mathrm{V}(\mathrm{D}) \mathrm{J}$ recombination and DNA repair. Mol Immunol 2006; 43:464-72.

19 Rugh R. The Mouse. Its Reproduction and Development, 1st edn. Edina, MN: Burgess Publishing Co., 1968.

20 Nguyen C, Rocha D, Granjeaud S, Baldit M, Bernard K, Naquet $\mathrm{P}$, Jordan BR. Differential gene expression in the murine thymus assayed by quantitative hybridization of arrayed cDNA clones. Genomics 1995; 29:207-15.

21 Bertucci F, Houlgatte R, Granjeaud S, et al. Prognosis of breast cancer and gene expression profiling using DNA arrays. Ann $N$ $Y$ Acad Sci 2002; 975:217-31.

22 Verdeil G, Puthier D, Nguyen C. Gene profiling approach to establish the molecular basis for partial versus full activation of naïve CD8 T lymphocytes. Ann N Y Acad Sci 2002; 975:68-76.

23 Lopez F, Rougemont J, Loriod B, et al. Feature extraction and signal processing for nylon DNA microarrays. BMC Genomics 2004; 29:38.

24 Quackenbush J. Microarray data normalization and transformation. Nat Genet Suppl 2002; 32:496-501.

25 Tusher VG, Tibshirani R, Chu G. Significance analysis of microarrays applied to the ionizing radiation response. Proc Natl Acad Sci USA 2001; 98:5116-21.

26 Su AI, Wiltshire T, Batalov S, et al. A gene atlas of the mouse and human protein-encoding transcriptomes. Proc Natl Acad Sci 2004; 101:6062-7.

27 Shortman K, Wu L. Early T lymphocyte progenitors. Annu Rev Immunol 1996; 14:29-47.

28 Anderson MS, Venanzi ES, Klein L, et al. Projection of an immunological self shadow within the thymus by the aire protein. Science 2002; 298:1395-401.

29 Puthier D, Joly F, Irla M, Saade M, Victorero G, Loriod B, Nguyen C. A general survey of thymocyte differentiation by transcriptional analysis of knockout mouse models. J Immunol 2004; 173:6109-18.

30 Terszowski G, Müller S, Bleul CC, et al. Evidence for a functional second thymus in mice. Science 2006; 312:284-7.

\section{Supplementary material}

The following supplementary material is avaible online for this article:

Table S1. Promiscuously induced genes in 20 days p.c. Balb-c thymus (FTOC).

This material is available as part of the online article from http://www.blackwell-synergy.com 


\title{
Hybridization signatures of gamma-irradiated murine fetal thymus organ culture (FTOC) reveal modulation of genes associated with T-cell receptor $\mathrm{V}(\mathrm{D}) \mathrm{J}$ recombination and DNA repair
}

\author{
Renato S. Cardoso a , Cristina M. Junta ${ }^{\text {a }}$, Claudia Macedo a , Danielle A.R. Magalhães ${ }^{\text {a }}$, \\ Eduardo L.V. Silveira ${ }^{a}$, Marina O. Paula ${ }^{a}$, Márcia M.C. Marques ${ }^{a}$, Stephano S. Mello ${ }^{b}$, \\ Carlos R. Zárate-Bladés ${ }^{\mathrm{c}}$, Catherine Nguyen ${ }^{\mathrm{d}}$, Remi Houlgatte ${ }^{\mathrm{d}}$, Eduardo A. Donadi ${ }^{\mathrm{e}}$, \\ Elza T. Sakamoto-Hojo ${ }^{b}$, Geraldo A.S. Passos ${ }^{a}, \mathrm{f}, *$ \\ ${ }^{a}$ Molecular Immunogenetics Group, Department of Genetics, Faculty of Medicine, University of São Paulo (USP), 14040-900 Ribeirão Preto, SP, Brazil \\ ${ }^{\mathrm{b}}$ Laboratory of Cytogenetics and Mutagenesis, Department of Genetics, Faculty of Medicine, USP, 14040-900 Ribeirão Preto, SP, Brazil \\ ${ }^{c}$ Basic and Applied Immunology Program, Faculty of Medicine, USP, 14040-900 Ribeirão Preto, SP, Brazil \\ ${ }^{\mathrm{d}}$ Advanced Technologies for the Genome and Clinics (TAGC), INSERM Unit ERM 206, 13288 Marseille, France \\ ${ }^{\mathrm{e}}$ Department of Medicine, Faculty of Medicine, USP, 14040-900 Ribeirão Preto, SP, Brazil \\ ${ }^{\mathrm{f}}$ Discipline of Genetics (DMEF), Faculty of Dentistry, USP, 14040-900 Ribeirão Preto, SP, Brazil
}

Received 28 October 2004; accepted 4 March 2005

Available online 13 April 2005

\begin{abstract}
In this study, we observed the occurrence of TRBV8.1-DB2.1 V(D)J recombination in murine fetal thymus organ culture (FTOC), in which the thymic microenvironment is mimicked. Since ionizing radiation affects T-cell development, we irradiated FTOCs with gamma rays to evaluate the modulation of genes implicated in TRBV8.1-BD2.1 rearrangements. The nylon cDNA microarray method was employed to monitor the expression of 9216 genes, which were organized in coexpression clusters. Clustering analysis showed similar expression profiling of genes implicated in the V(D)J recombination and DNA double strand break (DSB) repair processes such as XRCC4, RAG-2, Artemis and DNAPK-cs, thus suggesting overlap between the two processes. The RUNX3 gene, whose coded protein binds to the enhancers of TR genes, was also modulated and the DNA cross-linking LR1 gene, which plays a role in the opening of hairpin DNA structures and whose expression pattern is similar to Artemis, may play a role in the control of V(D)J recombination. Furthermore, our data demonstrate that the FTOC model system and cDNA microarray method are useful tools to evidentiate genes that may play a role in both processes $\mathrm{V}(\mathrm{D}) \mathrm{J}$ recombination and DNA repair. (C) 2005 Elsevier Ltd. All rights reserved.
\end{abstract}

Keywords: FTOC; T-cell receptor beta; V(D)J recombination; DNA repair; cDNA microarray; Transcriptome profiling; Ionizing radiation

\section{Introduction}

The differentiation of thymocytes to mature T-cells occurs within the fetal thymus and all developmental stages are distinguishable by their expression of a combination of CD cell-surface markers. This is a highly modulated phenomenon whose central molecular machinery is formed by the recombinase complex (recombination activating genes,

\footnotetext{
* Corresponding author. Tel.: +55 16602 30 30; fax: +55 166330069

E-mail address: passos@rge.fmrp.usp.br (G.A.S. Passos).
}

RAG-1 and RAG-2) directly implicated in the V(D)J recombination of T-cell receptor (TRA, TRB, TRG and TRD) and immunoglobulin (Ig) gene segments (Lefranc and Lefranc, 2001).

The occurrence of the $\mathrm{V}(\mathrm{D}) \mathrm{J}$ reaction is important for triggering the maturation of T-cells and is also regulated by several other gene products such as interleukins (Muegge et al., 1993; Sollof et al., 1997; Fink and McMahan, 2000; Fugmann, 2002; Espanhol et al., 2003). Using the cDNA array method, we have previously found that during a fetal phase of the in vivo development of the murine thymus, when 
the TR gene rearrangements begin, several genes related to DNA synthesis, protein metabolism, oncogenes, transcription factors and signal transduction are modulated in concert (Espanhol et al., 2004; Magalhães et al., 2005).

Functional analysis of T-cell development has become possible after the introduction of techniques in which the thymic microenvironment is mimicked, such as fetal thymus organ culture (FTOC). This method is based on the use of early fetal thymus tissue, which is composed of homogeneous thymocyte population (double-negative cells), and on the possibility of testing the induction of alterations in gene expression during T-cell development caused by chemical and physical agents (DeLuca et al., 1995).

In the present study, we demonstrated the occurrence of the TRBV8.1-BD2.1 rearrangement in FTOCs, indicating the occurrence of T-cell maturation in vitro. Moreover, the FTOC transcriptome profiling was accessed using a set of six nylon cDNA microarrays containing a total of 9216 thymus IMAGE sequences.

Comparing time of thymus gestation as a result of age of fetuses and length of cultures, versus gamma-irradiated and unirradiated cultures, it was possible to found genes differentially expressed, several among them were considered to be novel candidates participating simultaneously in the control of T-cell receptor $\mathrm{V}(\mathrm{D}) \mathrm{J}$ recombination and DNA repair.

Each phase of thymus development in FTOCs exhibited a characteristic gene expression pattern involving genes of known functions, permitting the identification of those implicated in T-cell maturation, including the V(D)J recombination process.

Since in the both processes, DNA repair of damage caused by ionizing radiation and T-cell receptor $\mathrm{V}(\mathrm{D}) \mathrm{J}$ recombination occurs reparation of DNA double-strand breaks (DSBs) (Prise et al., 2001; Toki et al., 2003), we irradiated FTOCs with gamma rays to evaluate the effects on TRB V(D)J recombination and on modulation of genes implicated in these mechanisms.

Among the genes which were found to be differentially expressed, several were considered to be novel candidates participating simultaneously in the control of T-cell receptor $\mathrm{V}(\mathrm{D}) \mathrm{J}$ recombination and DNA repair.

\section{Material and methods}

\subsection{Fetal thymus organ culture, total RNA and genomic DNA preparations}

BALB-c mice were bred in an $0.45 \mu \mathrm{m}$ pore size air filtered isolator in our own breeding facility. To obtain timed pregnancies, mice were mated and the day when the vaginal plug was obtained at 7:00 am was considered to be day zero of gestation post coitum (pc). Pregnant mice were sacrificed by ether inhalation and the fetuses collected by surgery of the uterus. The pc age of fetuses was confirmed by the morpho- logical characteristics of each developmental phase (Rugh, 1968).

Thymi were removed from the fetuses under a stereomicroscope and cultured according to the organ culture technique described by DeLuca et al., (1995). The organs were dissected and cleaned from adjacent tissue and placed on the surface of Millipore filters $(0.45 \mu \mathrm{m}$ pore size $)$ pre-embedded with culture medium. These filters were supported on plastic grids in $2 \mathrm{ml}$ Dulbecco's modified Eagle's Medium/HAM F-10 culture medium (GIBCO, USA) supplemented with $20 \%$ heat inactivated fetal bovine serum (Biobrás, Brazil). The medium was also supplemented with $100 \mu \mathrm{g} / \mathrm{ml}$ streptomycin, $250 \mathrm{U} / \mathrm{ml}$ penicillin, $10 \mu \mathrm{g} / \mathrm{ml}$ gentamicin, $1 \mathrm{mM}$ sodium pyruvate, $20 \mu \mathrm{M}$ 2-mercaptoethanol and $3.4 \mathrm{~g} / \mathrm{L}$ sodium bicarbonate. The incubation time of the organ culture varied from 2 to 5 days at $37^{\circ} \mathrm{C}$ in a $5 \% \mathrm{CO}_{2}$ incubator.

Thymi were dissected from fetuses obtained at 13,14 and 15 days of gestation and cultured for two days, respectively, mimicking 15, 16 and 17 days of in vivo development. Thymi from 15 days pc fetuses were also cultured for 5 days, mimicking the 20th day of in vivo development, and in this case, the culture medium was changed on the 3rd day of incubation.

Immediately after culture preparation, some FTOCs were irradiated with $4 \mathrm{~Gy}$ of gamma rays from ${ }^{60} \mathrm{Co}$ source using a Gammatron S-80 apparatus (Siemens, Germany) at the dose of $0.53 \mathrm{~Gy} / \mathrm{min}$. Control cultures were sham irradiated.

In order to evaluate the viability of FTOCs before and after irradiation, three randomly selected thymus of each group was used for the single cell suspensions preparation which were separately stained with acridine orange $(100 \mu \mathrm{g} / \mathrm{ml})$ or with ethidium bromide $(100 \mu \mathrm{g} / \mathrm{ml})$ and analyzed on a Axiophot II fluorescence microscope (Carl Zeiss, Germany) in order to evaluate the frequency of apoptosis and necrosis, respectively.

Total RNA and genomic DNA were prepared from FTOCs using Trizol ${ }^{\circledR}$ reagent according to manufacturer instructions (Invitrogen, USA).

\subsection{Semiquantitative TRBV8.1-BD2.1 recombination assay}

T-cell maturation was monitored by detection of rearrangements between segments TRBV8.1 and BD2.1 during FTOC development using PCR as previously described (Muegge et al., 1993). The oligonucleotide primers were the BV8.1 forward primer (primer 1, CAGGCTGCAGTCACCCAAAGTCCAA), the BV8.1 reverse primer (primer 2, ACAGAAATATACAGCTGTCTGAGAA) and the BJ2.1 reverse primer (primer 3, TGAGTCGTGTTCCTGGTCCGAAGAA). The PCR mixture contained $35 \mathrm{mM}$ Tris, $\mathrm{pH}$ $8.3,50 \mathrm{mM} \mathrm{KCl}, 2.5 \mathrm{mM} \mathrm{MgCl} 2,100 \mu \mathrm{g} / \mathrm{ml}$ bovine serum albumin, nucleotide triphosphates (NTPs) $(2 \mu \mathrm{M}$ each), the primers $(0.5 \mu \mathrm{M}$ each) and $1 \mathrm{U}$ Taq polymerase (Amersham Biosciences, Buckinghamshire, UK), with a constant amount of genomic DNA $(1 \mu \mathrm{g})$ from each developmental stage in FTOC. The PCR program consisted of 30 cycles (1 min at 
$94{ }^{\circ} \mathrm{C}, 2.5 \mathrm{~min}$ at $54^{\circ} \mathrm{C}$ and $1.5 \mathrm{~min}$ at $70^{\circ} \mathrm{C}$, with a 7 -min extension period).

In order to make this PCR a semiquantitative method, we included in the mix an internal amplification control of the $\beta$-actin gene ( $\beta$-actin forward ATGGATGACGATATCGCT and $\beta$-actin reverse ATGAGGTAGTCTGTCA). The adequate number of PCR cycles to reach the log-phase amplification was determined in experiments with 25,30 and 35 PCR cycles. The signal generated by the 30 -cycle PCR was significantly lower than that generated by the 35-cycle PCR. This result demonstrates that at 30-cycle PCR, the amplification of the TRBV8.1-BD2.1 rearranged segment (and the beta-actin segment) was at log-phase and was adopted in this study (data not shown).

After cycling, $15 \mu \mathrm{l}$ of PCR products were resolved by $1.8 \%$ agarose gel electrophoresis and transferred (blotting) to a nylon Hybond $\mathrm{N}+$ membrane (Amersham Biosciences). The PCR products were identified by hybridization with 7-15 million cpm of each T-cell receptor beta (TRBV8.1) and $\beta$ actin ${ }^{32} \mathrm{P}$ radiolabeled probe.

Imaging plates and a phosphor imager apparatus $(\mathrm{Cy}-$ clone model, Packard Instruments, USA) were used to capture the hybridization signals and the OptiQuant ${ }^{\circledR}$ software (Packard) was used to quantify the signals with local background subtraction. The adequate level of image saturation was ensured by serial dilution of the positive control (data not shown).

For the data from V(D)J recombination experiments we applied $t$-test as statistical method of analysis and a $P$ value $<0.05$ was considered to be significant from three independent determinations.

\section{3. cDNA microarray method}

We used a set of six microarrays containing a total of 9216 cDNA sequences in the form of PCR products, spotted in duplicate on $2.5 \mathrm{~cm} \times 7.5 \mathrm{~cm}$ Hybond $\mathrm{N}+$ nylon membranes (Amersham Biosciences). The arrays were prepared in our laboratory using a Generation III Array Spotter (Amersham Biosciences-Molecular Dynamics, USA).

Mouse thymus expressed sequence tag (EST) cDNA clones were obtained from the Soares thymus 2NbMT normalized library, prepared from a C57B1/6J 4-week-old male thymus, and available from the I.M.A.G.E. Consortium (http://image.llnl.gov/image/html/iresources.shtml) and from the RZPD Deutsches Ressourcenzentrum für Genomforschung $\mathrm{GmbH}$ (www.rzpd.de).

The cDNA inserts were homogeneous in size (near $1 \mathrm{~kb}$ ) and cloned in three vectors ( $\mathrm{pT} 7 \mathrm{~T} 3 \mathrm{D}$, pBluescript and Lafmid) and were amplified on 384- or 96-well plates using vector-PCR amplification with the following primers, which recognize the three vectors: LBP 1S GTGGAATTGTGAGCGGATACC forward and LBP 1AS GCAAGGCGATTAAGTTGG reverse.

The membranes were first hybridized with the LBP 1 AS $\left[\gamma^{-}{ }^{33} \mathrm{P}\right] \mathrm{dCTP}-$ labeled oligonucleotide (vector hybridization).
Quantification of the obtained signals allowed the estimation of the amount of cDNA insert deposited in each spot. After stripping, the membranes were used for hybridization with cDNA complex probes (sample hybridization).

The characterization of each cDNA sequence was updated using the Eloge ${ }^{\circledR}$ (Ipsogen, France, www.ipsogen.fr) software, which runs on our local server and links each clone ID with the genome data banks GenBank (www.ncbi. nlm.nih.gov) and S.O.U.R.C.E. (http://genome-www5. stanford.edu/cgi-bin/source/sourceSearch), providing information such as DNA and protein sequences, biological and molecular functions and chromosomal location.

\subsection{Complex $c D N A$ probe preparation and hybridization}

In this study, we refer to the radioactive cDNA originating from the thymus RNA samples (FTOCs) as complex probe and to the PCR product originating from the clones and deposited on nylon microarrays as target.

The ${ }^{33} \mathrm{P}$-labeled cDNA complex probes were prepared by reverse transcription of $10 \mu \mathrm{g}$ of thymus total RNA using oligo $\mathrm{dT}_{12-18}$ as primer. One-hundred $\mu{ }^{33} \mathrm{P}$-cDNA complex probe containing 30-50 million cpm was hybridized with nylon microarrays as previously described (Nguyen et al., 1995; Bertucci et al., 2002; Verdeil et al., 2002).

\section{5. cDNA microarray image acquisition}

We used imaging plates and a phosphor imager apparatus (Packard model Cyclone) to capture the hybridization signals and the BZScan software (available from the authors at http://www.tagc.univ-mrs.fr) to quantify the signals with local background subtraction, whose spots were matched with a template grid.

The ratio between vector probe hybridization values and complex probe hybridization values for each spot was used as reference normalization value. We also employed total intensity normalization using the median expression value (Quackenbush, 2002).

\subsection{Hierarchical clustering}

We used a hierarchical clustering algorithm, comparing means of different genes whose standard deviation did not overlap, and whose objective was to compute a dendrogram that assembles all elements into a single tree. The software for this algorithm can be obtained from the authors (Eisen et al., 1998) at (http://rana.stanford.edu/clustering). Before clustering, the gene expression values were mediancentered and log transformed using the Pearson correlation distance metrics and average linkage for clustering organization from six independent determinations of each situation studied. 


\section{Results}

\subsection{Monitoring thymocyte maturation in FTOCs}

The detection of the TRBV8.1-BD2.1 rearranged DNA segment was evidence for thymocyte maturation in FTOCs. Using a semiquantitative PCR method, it was possible to detect significant amounts $(P<0.05)$ of amplification products for both the $\beta$-actin internal control and the TRBV8.1-BD2.1 segment (Fig. 1). The onset of $\mathrm{V}$ (D)J recombination occurred at the 14 day pc fetal thymi after 2 days in FTOC (these 2 days of incubation time correspond to the 16th day of gestation in vivo).

Gamma irradiation caused a 1.5-fold significant increase $(P<0.05)$ of the TRBV8.1-BD2.1 segment in 15 day pc fetal thymus incubated for five days in FTOC (corresponding to the 20th day pc in vivo); however, organ irradiation did not change the onset of recombination, which also occurred in irradiated 14 day pc fetal thymus (corresponding to the 16th day of gestation in vivo). This dose of gamma irradiation did not significantly changed cell viability ( $t$-test, $P<0.05)$ of FTOCs as evaluated by determination of frequency of apoptotic and necrotic cells (Table 1).

\subsection{Hierarquical clustering}

The hierarchical cluster analysis of the results obtained for a total of 9216 sequences by comparison between irradiated and non-irradiated FTOCs showed variability in the hybridization signatures of gene expression presented by different cultures. The dendrogram shows that this variability allowed the distinction of samples according to incubation time, as well as the distinction between control and irradiated FTOCs (Fig. 2).

It was possible to identify several clusters of repressed and induced genes. However, six of them which included
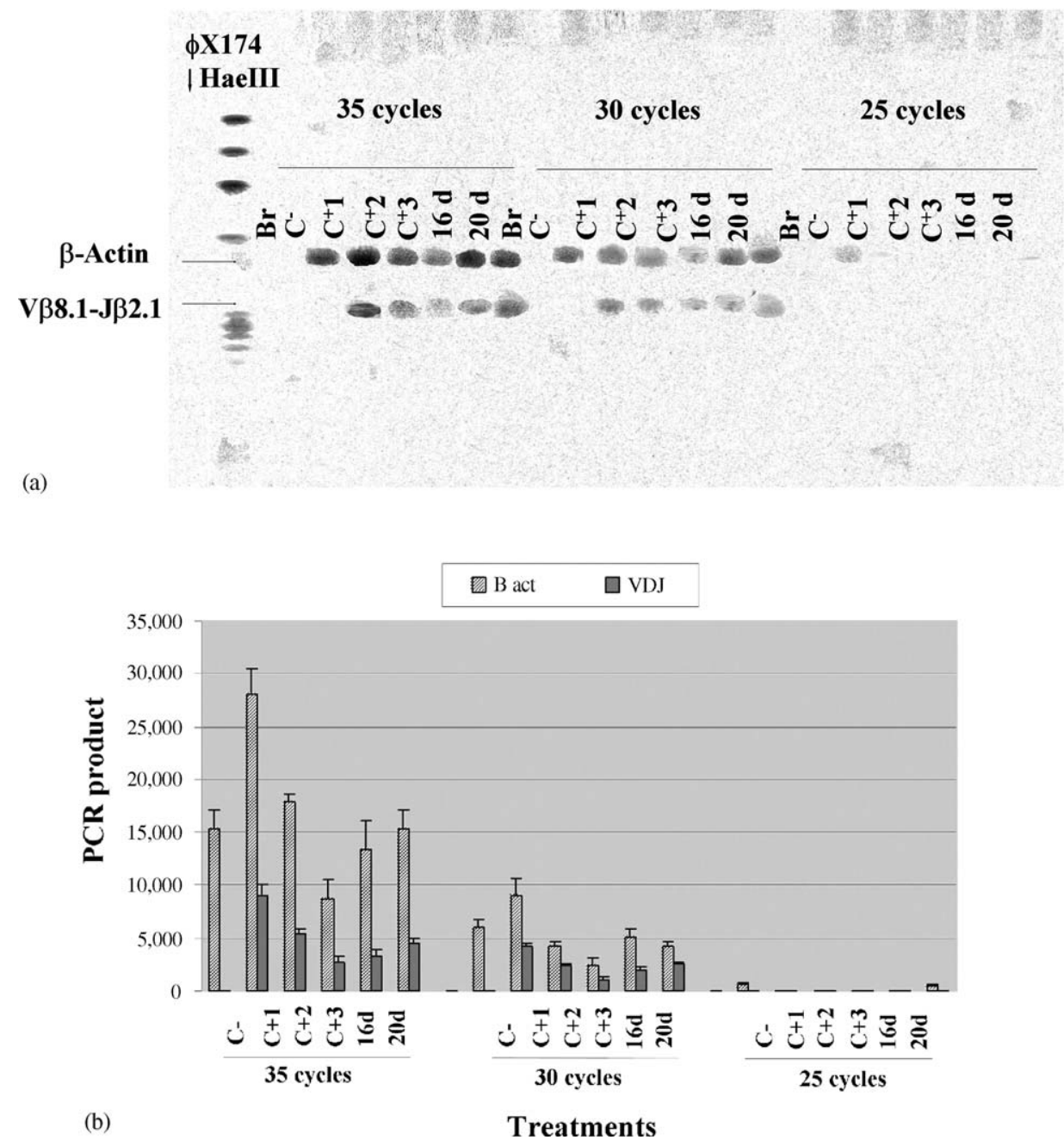

Fig. 1. Semiquantitative detection of V(D)J recombination between TRBV8.1 and BD2.1 during thymus development in control and gamma-irradiated FTOCs. Polymerase chain reactions were performed using TRBV8.1 and BD2.1 specific primers together with beta-actin primers as internal control in order to monitor reactions and normalize data. The 30-cycle PCR allowed amplification of the TRBV8.1-BD2.1 rearranged segment (and beta-actin segment) at log-phase. (A) Southern-blot of PCR products. (B) Quantification of hybridizations using a phosphor-imager. Arbitrary normalized values (on the basis of beta-actin values) expressed as digital light units (DLU) as displayed by the OptiQuant ${ }^{\circledR}$ software. 
Table 1

Frequency (\%) of apoptotic and necrotic cells in $4 \mathrm{~Gy}$ irradiated and control FTOCs

\begin{tabular}{llllll}
\hline & \multicolumn{2}{l}{ Apoptosis } & & \multicolumn{2}{l}{ Necrosis } \\
\cline { 2 - 3 } \cline { 6 - 6 } \cline { 6 - 6 } & Staging & & Staging & \\
\hline Control & 15 & $1.2 \pm 0.5$ & & 15 & $4.1 \pm 1.5$ \\
& 16 & $1.0 \pm 0.5$ & & 16 & $3.0 \pm 1.0$ \\
& 17 & $3.2 \pm 1.0$ & & 17 & $5.2 \pm 1.5$ \\
& 20 & $2.0 \pm 1.0$ & 20 & $2.7 \pm 1.0$ \\
Irradiated & 15 & $1.8 \pm 1.0$ & & 15 & $4.1 \pm 0.5$ \\
& 16 & $1.9 \pm 1.0$ & & 16 & $4.2 \pm 1.0$ \\
& 17 & $3.0 \pm 0.5$ & & 17 & $2.3 \pm 0.5$ \\
& 20 & $2.1 \pm 1.0$ & 20 & $5.8 \pm 1.5$ \\
\hline
\end{tabular}

Mean and standard deviation of three independent determinations. Data analyzed by $t$-test $(P<0.05)$.

Staging corresponds to development of fetal thymus in culture; 15 FTOC $=13$ day gestation thymus plus two days in FTOC.

genes implicated in cell cycle control, DNA repair, T-cell differentiation and $\mathrm{V}(\mathrm{D}) \mathrm{J}$ recombination were selected for discussion. The complete color heat-map indicating the six gene clusters is available online at (www.rge.fmrp. up.br/passos/FTOCcluster/9216).

Among the genes differentially expressed, we selected 42 to discuss from six clusters whose functions are associated with cell cycle control, transcription factors, immune regulation, T-cell V(D)J recombination and DNA repair (Table 2).

\section{Discussion}

\subsection{T-cell receptor and TRBV8.1 rearrangement occurs in vitro in FTOC}

The IL-7 is a cofactor associated with modulation of V(D)J recombination of TCR genes (Muegge et al., 1993; Sollof et al., 1997).

In this study, we described for the first time the occurrence of TRBV8.1-BD2.1 V(D)J recombination in vitro in FTOC.

The onset of TRBV8.1-BD2.1 V(D)J recombination in vitro mimicked the thymus gestation in vivo, demonstrating that this model system is similar to the in vivo development of

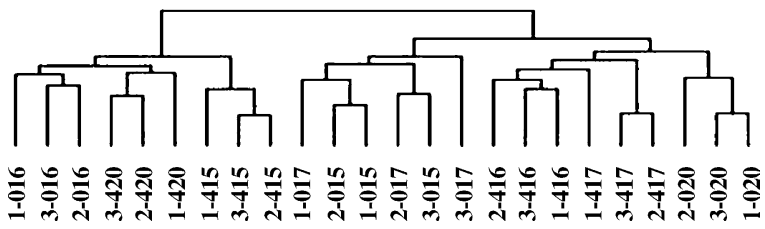

Fig. 2. Clustering RNA (cDNA) samples and 9216 genes of each developmental phase of control and gamma-irradiated FTOCs. The hierarchical clustering algorithm compared means of the different genes and RNA (cDNA) samples whose standard deviations did not overlapped computing the dendrogram that assembled all elements into a tree. Complete color heat-map indicating the repressed, induced and unmodulated genes among all situation studied is available online at (www.rge.fmrp.usp.br/passos/ FTOC/cluster9216). the thymus in inbred mouse strains, as previously described by our group (Espanhol et al., 2003; Macedo et al., 1999).

On the basis of a variety of criteria, FTOC reproduces the normal thymic development; however, the results can be influenced by the length of culture, and mouse strain and age (DeLuca et al., 1995).

In addition, it was shown that there are differences in temporal rearrangements at the TRBV locus, including the TRBV8.1 segment, among BALB-c, C57B1/6 and CBA/J inbred mouse strains, probably due to the different genetic backgrounds of the different strains (Espanhol et al., 2003; Macedo et al., 1999; Junta and Passos, 1998).

For this reason, the fetuses used in this study were obtained within the age range of 13-15 days of gestation pc, which permitted comparisons with the data obtained in vivo with the BALB-c strain.

\subsection{Hierarchical clustering}

The expression patterns disclosed several clusters of coexpressed genes, six of which (clusters 1-6) were selected for discussion on the basis of the biological functions of the most relevant genes investigated in this study.

Cluster 1 (correlation $=0.81$ ) harbors genes which were induced in irradiated cultures. This cluster displayed genes involved in cell cycle/cell division and DNA repair. Among them, we pinpointed MYB (myeloblastosis oncogene, accession no. NM010848, chromosome 10), which has a role in transcriptional activation and in the control of proliferation and differentiation of hematopoietic progenitor cells, and Kirsten rat sarcoma oncogene 2 (KRAS2, accession no. NM021284, chromosome 6). This oncogene belongs to the small GTPase superfamily (ras family), whose proteins bind to GDP/GTP and possess intrinsic GTPase activity. Its biological function is associated with control of the cell cycle. The induction of these oncogenes suggests triggering cell division by irradiation in FTOCs.

Interestingly, the cell division cycle 42 homolog $S$. cerevisiae gene (CDC42, accession no. NM009861, chromosome 4) which plays a role in GTPase-mediated signal transduction and participates in cytokinesis, presented an expression profile similar to that of the KRAS2 oncogene, suggesting that GTPase activity seems to be required after exposure to ionizing radiation.

The X-ray repair complementing defective repair in Chinese hamster cells 5 gene (Ku80) (XRCC5, accession no. NM009533, chromosome 1) participates in the mechanism of DNA double-strand break repair (DSB repair) via NHEJ. The induction of the XRCC5 gene suggests that NHEJ may constitute an important process of DNA repair in irradiated FTOCs.

Cluster 2 (correlation $=0.71$ ) encompasses genes involved in the regulation of transcription in T-cells such as signal transducer and activator of transcription 4 gene (STAT4, accession no. NM011487, chromosome 1), whose activities are associated with a transcription factor and 
Table 2

Genes differentially expressed (induced) in gamma-irradiated compared to control FTOCs as displayed by the Cluster and TreeView program

\begin{tabular}{|c|c|c|c|c|}
\hline Cluster & Gene name & Accession no. & Chromosome & Function \\
\hline \multirow[t]{4}{*}{1} & Myeloblastosis oncogene & NM10848 & 10 & Oncogene \\
\hline & Kirsten rat sarcoma oncogene 2 & NM021284 & 6 & Oncogene \\
\hline & Cell division cycle 42 & NM009861 & 4 & GTPase-signal transduction \\
\hline & Ku 80, X-ray repair, XRCC5 & NM009533 & 1 & DSB repair \\
\hline \multirow[t]{3}{*}{2} & Signal transducer activation of transcription & NM011487 & 1 & Transcription factor \\
\hline & Neuroprotective protein gene & AK129214 & $2 \mathrm{H} 3$ & Transcription factor \\
\hline & Nuclear factor of activated T-cells & AK048610 & 18 & Induction of cytokines \\
\hline \multirow[t]{9}{*}{3} & Transcription elongation factor 1 & AK048564 & $1 \mathrm{H} 2$ & RNA pol II transcription \\
\hline & Transcription elongation factor 3 & AJ223472 & 4D3 & RNA pol II transcription \\
\hline & Runt-related transcription factor 3 & AK053910 & 4 & Enhancer binding protein \\
\hline & Thyroid autoantigen $\mathrm{Ku} 70$ & BC051085 & 15 & DSB repair \\
\hline & Janus kinase 3 & $\mathrm{~L} 40172$ & 8 & IL2/IL4 signaling \\
\hline & Interleukin receptor IL-11TRA2 & X98519 & 4 & Immune response/V(D)J recombination \\
\hline & Interleukin receptor IL-7R & NM008372 & 15 & TCR V(D)J recombination \\
\hline & Tumor necrosis factor, member7 & L24495 & 6 & Survival of activated T-cells \\
\hline & Granzyme A & M13226 & 13 & Targeting cell lysis \\
\hline \multirow[t]{5}{*}{4} & Fibroblast growth factor receptor 1 & BC010200 & 8 & Embriogenesis \\
\hline & Vascular cell adhesion molecule 1 & AK089320 & 3 & Cell adhesion \\
\hline & Retinoblastome binding protein 7 & BC003785 & XF4 & Negative regulation of transcription \\
\hline & SRY-box-SOX-4 & AK028989 & 13 & Binding to T-cell enhancer \\
\hline & Artemis protein & AK052369 & $2 \mathrm{~A} 1$ & TCR V(D)J recombination \\
\hline \multirow[t]{7}{*}{5} & Mitogen activated protein kinase 7 & ВC070467 & $8 \mathrm{~A} 1.1$ & Activation of Jun kinases \\
\hline & Insulin-like growth factor binding protein 7 & AB012886 & $5 \mathrm{D}$ & Regulation of cell growth \\
\hline & A-disintegrin and metalloprotease domain 8 & $\mathrm{BC} 025584$ & 7F3-F5 & Extravasion of leukocytes \\
\hline & Nuclear transcription factor Y-gamma & $\mathrm{BC} 053723$ & 4 & Transcription factor \\
\hline & Tripartite motif protein 28 & NM011588 & 7A1 & Transcription factor \\
\hline & Protease, serine, 16 (thymus) & AK088019 & 13 & Protease, T-cell development \\
\hline & Calpain 8 & NM130890 & $1 \mathrm{H} 5$ & Endopeptidase \\
\hline \multirow[t]{14}{*}{6} & $\mathrm{X}$-ray repair, XRCC4 & AK038105 & $13 \mathrm{C} 3$ & DSB repair \\
\hline & Heat shock protein 1-like & D85732 & 17 & Cooperation with chaperones \\
\hline & $\mathrm{XPC}$, xeroderma pigmentozum $\mathrm{C}$ & AK028595 & $6 \mathrm{D}$ & DNA excision repair (NER) \\
\hline & Interleukin IL-1B & NM008361 & 2 & Immune response \\
\hline & Interleukin IL-2 & X01772 & 3 & Immune response \\
\hline & Interleukin IL-6 & AK089780 & 5 & Immune response \\
\hline & Interleukin Il-7 & AK041403 & 3 & Immune response/ $\mathrm{V}(\mathrm{D}) \mathrm{J}$ recombination \\
\hline & Lymphotoxin A & NM10735 & 17 & Cytotoxic for tumor cells \\
\hline & Cyclin D3 & AK046638 & 17 & Protein kinase \\
\hline & EGR1, early growth response 1 & M22326 & 18 & Transcriptional regulator \\
\hline & RAG-2, recombination activator gene 2 & AK040375 & 2 & $\mathrm{~V}(\mathrm{D}) \mathrm{J}$ recombination \\
\hline & DNA-activated protein kinase & AK088981 & 16 & DSB repair and $\mathrm{V}(\mathrm{D}) \mathrm{J}$ recombination \\
\hline & MMTV endogenous retrovirus & B4515481 & 19 & Superantigen \\
\hline & DNA cross-link LR1 & ВC011094 & $3 \mathrm{~F} 2.2$ & Nucleotide excision repair \\
\hline
\end{tabular}

a cytokine- and chemokine-mediated signaling pathway. Activity-dependent neuroprotective protein gene (ADNP, accession no. AK129214, chromosome 2H3) encodes a DNAbinding protein with transcription factor activity and nuclear factor of activated T-cells, cytoplasmic 1 gene (NFATC1, accession no. AK048610, chromosome 18) plays a role in the inducible expression of cytokine genes in T-cells, especially, in the induction of the IL-2 or IL-4 gene transcription.

The expression patterns of these genes in non-irradiated FTOCs suggest a tendency of induction at the early stages and repression at the late stages.

Cluster 3 (correlation $=0.71$ ) also encompasses genes involved in the regulation of transcription such as TCEA1 and TCEA3 (transcription elongation factor gene 1, accession no. AK048564, chromosome 1A2 and gene 3, accession no. AJ223472, chromosome 4D3), necessary for efficient RNA polymerase II transcription elongation past template-encoded arresting sites. Cleavage of the nascent transcript by S-II allows the resumption of elongation from the new $3^{\prime}$ terminus. The Runt-related transcription factor 3 gene (RUNX3 gene, accession no. AK053910, chromosome 4) codes for a protein that binds to the enhancers of T-cell receptor genes. As enhancers of TRs play a role in the control of gene rearrangements (Hempel et al., 1998), RUNX3 could participate in the control of TR V(D)J recombination.

G22P1 (Ku70) (thyroid autoantigen gene, accession no. BC051085, chromosome 15) plays a role in DSB repair via nonhomologous end-joining. Ku70/80 heterodimer is the 
DNA-binding subunit of DNA-PK, an important component of the repair of DSB via NHEJ (Lees-Miller and Meek, 2003).

Absence of Ku70 leads to hypersensitivity to ionizing radiation. Janus kinase 3 gene (JAK3, accession no. L40172, chromosome 8) codes for a tyrosine kinase of the nonreceptor type involved in the IL-2 and IL-4 signaling pathway. This gene belongs to the Tyr family of protein kinases and is implicated in lymph gland development. The interleukin receptor genes IL-11RA2 (accession no. X98519, chromosome 4) and IL-7R (accession no. NM008372, chromosome 15) are also present in cluster 3 and may later be associated with IL-7 signaling, which plays a role in the $\mathrm{V}(\mathrm{D}) \mathrm{J}$ recombination of TRs (Muegge et al., 1993; Sollof et al., 1997).

In addition, we observed genes associated with apoptosis such as tumor necrosis factor receptor superfamily, member 7 gene (TNFRSF7, accession no. L24495, chromosome 6) and GZMA (granzyme A gene, accession no. M13226, chromosome 13). TNFRSF7 encodes a receptor for tnfsf7/cd27l, possibly playing a role in survival of activated T-cells, while GZMA codes for a granzyme A precursor, an enzyme necessary for targeting cell lysis in cell-mediated immune responses.

Therefore, the induction of several genes in cluster 3 suggests the occurrence of T-cell differentiation following the irradiation stimulus in irradiated FTOCs.

Cluster 4 (correlation $=0.81$ ) contains genes with induced expression in irradiated FTOCs similar to cluster 3. Among the modulated genes, two may play a role in thymus morphogenesis in FTOC, the fibroblast growth factor receptor 1 gene (FGFR1, accession no. BC010200, chromosome 8) which may be essential for generation of mesodermal and endodermal layers and invaginations of various types of cells, and vascular cell adhesion molecule 1 gene (VCAM1, accession no. AK085320, chromosome 3) which is important in cell-cell recognition and appears to function in leukocyte-endothelial cell adhesion.

Two genes implicated in the control of transcription such as retinoblastoma binding protein 7 gene (RBBP7, accession no. BC003785 chromosome XF4) which plays a role in the negative regulation of transcription from the polymerase II promoter and SRY-box containing gene 4 (SOX4, accession no. AK028989, chromosome 13) which codes for a transcriptional activator that binds with high affinity to the T-cell enhancer $5^{\prime}$-AACAAAG-3' motif, may be associated with the control of V(D)J recombinations in FTOCs, in concert with the Artemis gene accession no. AK052369, chromosome $2 \mathrm{~A} 1$, which is directly associated with T-cell receptor gene rearrangements since these genes were included in the same cluster.

Cluster 5 (correlation $=0.78$ ) harbors genes, which were induced in irradiated FTOCs. Among these genes, we observed those associated with cell proliferation such as mitogen activated protein kinase 7 gene (MAP2K7, accession no. BC070467, chromosome 8A1.1) which has dual kinase activities involving the activation of jun kinases mapk8 (jnk1) and mapk9 (jnk2); as well as insulin-like growth factor binding protein 7 gene (IGFBP7, accession no. AB012886, chromosome 5D) that plays a role in the regulation of cell growth.

A gene associated with cell organization and biogenesis, A-disintegrin and metalloprotease domain 8 gene (ADAM8, accession no. BC025584, chromosome 7F3-F5), which is possibly involved in extravasation of leukocytes, was induced. As mature T-cells migrate from the thymus to the periphery, this gene could be implicated in such process.

Transcription factors such as nuclear transcription factorY gamma gene (NFYC, accession no. BC053723, chromosome 4), 3FP62 (tripartite motif protein 28 gene) (TRIM 28, accession no. NM011588 chromosome 7A1) form a complex with a krab-domain transcription factor and increase the efficiency of krab-mediated repression by recruiting setdb1 to histone $\mathrm{H} 3$ (by similarity).

We also observed induction of those genes implicated in protein metabolism such as PRSS16 [protease, serine, 16 (thymus) gene, accession no. AK088019, chromosome 13] which codes for a protease that may play a role in T-cell development and is specifically expressed in the developing thymus, and calpain 8 gene (CAP8, accession no. NM130890, chromosome 1H5) that codes for a cysteine-type endopeptidase and whose enzyme is involved in proteolysis and peptidolysis.

Cluster 6 (correlation $=0.77$ ) is formed by genes whose functions are directly related to the response to DNA damage stimulus such as X-ray repair complementing defective repair in Chinese hamster cells 4 gene (XRCC4, accession no. AK038105, chromosome 13C3) involved in DSB repair and heat shock protein 1-like gene (HSC70T, accession no. D85732, chromosome 17) whose coded protein in cooperation with other chaperones, for example HSP70, stabilizes pre-existing proteins against aggregation and mediates the folding of newly translated polypeptides in the cytosol, as well as within organelles. These chaperones participate in the recognition of non-native conformations of proteins. Another gene present in the cluster 6 was xeroderma pigmentosum, complementation group C gene (XPC, accession no. AK028595, chromosome 6D), which encodes a DNA repair protein, which is involved in DNA excision repair (NER) and may play a role in DNA damage recognition. XPC seems to recognize DNA helix distortions (Gontijo et al., 2003) and is responsible by opening the DNA helix in response to DNA damage (Tapias et al., 2004).

Moreover, as the DNA repair XPC protein may alter chromatin structure, it is plausible that its action could facilitate the accessibility of the V(D)J machinery to the TR locus.

We also found genes directly associated with immune response/activation and with the $\mathrm{V}(\mathrm{D}) \mathrm{J}$ recombination process. There are four interleukin genes, IL-1B, accession no. NM008361, chromosome 2; IL-2, accession no. X01772, chromosome 3; IL-6, accession no. AK089780, chromosome 5 and IL-7, accession no. AK041403, chromosome 3. The IL-7 is a cofactor associated with modulation of V(D)J 
recombination of TRB8.1 [2,3]. The lymphotoxin A gene, accession no. NM010735, chromosome 17, codes for the tumor necrosis factor produced by lymphocytes. This protein is cytotoxic for a wide range of tumor cells in vitro and in vivo.

Two genes in cluster 6 are implicated in immune cell activation, cyclin D3 gene (CCND3, accession no. AK046638, chromosome 17) codes for a cdk6 protein kinase essential for the control of the cell cycle at the G1/S transition and early growth response 1 gene (EGR1, accession no. M22326, chromosome 18) codes for a transcriptional regulator (early growth response protein 1) that activates the transcription of target genes whose products are required for mitogenesis and differentiation.

Finally, we found genes in this cluster closely implicated in the $\mathrm{V}(\mathrm{D}) \mathrm{J}$ recombination mechanism of T-cell receptor genes and immunoglobulins (Ig). The recombination activating gene 2 (RAG-2, accession no. AK040375, chromosome 2) codes for recombinase 2 , a component of the rag enzymatic complex (rag complex formed by rag- 1 and rag- 2 recombinases). This complex recognize and binds to the recombination signal sequences (RSSs) at the unrearranged TR or Ig loci, consisting of conserved heptamer and nonamer motifs separated by a spacer region of 12 or $23 \mathrm{bp}$.

$\mathrm{V}(\mathrm{D}) \mathrm{J}$ recombination results in a precise head-to-head ligation of two signal sequences in a joint signal, which may contain additions or deletions of a few bp. The reaction is initiated by the formation of DSB, which is resolved by the DNA repair machinery, followed by an exonuclease and/or by terminal deoxynucleotidyl transferase (TdT) before formation of a coding joint.

Mice that do not express RAG-1 or RAG-2 genes are unable to form DSB and there is evidence that DNA DSB repair and $\mathrm{V}(\mathrm{D}) \mathrm{J}$ recombination share a partially common mechanism (Schlissel et al., 1993; Chaudhuri and Alt, 2004; Jeggo and Concannon, 2001).

DNA-activated protein kinase gene (DNA-PK $\mathrm{Cs}_{\mathrm{cs}}$, accession no. AK088981, chromosome 16), also present in cluster 6 , codes for a large polypeptide DNA-dependent protein kinase catalytic subunit and its kinase activity is involved in DNA NHEJ required for DSB repair and V(D)J recombination. DNA-PK $\mathrm{cs}_{\mathrm{cs}}$ forms a complex with two subunits of the heterodimeric Ku protein $(\mathrm{Ku} 70$ and $\mathrm{Ku} 80)$ and must be bound to DNA to express its catalytic properties; cells that lack DNA-PK $\mathrm{cs}_{\mathrm{cs}}$ are radiosensitive and defective in DNA repair, while DNA-PK $\mathrm{Cs}_{\mathrm{cs}}$ null mice are viable but immunodeficient, due to inability to complete $\mathrm{V}(\mathrm{D}) \mathrm{J}$ recombination (Lees-Miller and Meek, 2003; Pastwa and Blasiak, 2003).

The assembly of the DNA-PK $\mathrm{Cs}_{\mathrm{cs}}$ complex to DNA ends is required for NHEJ binding step. Interestingly, the XRCC4 repair gene was also observed in cluster 6 , and the product of this gene was found to interact with DNA ligase IV stimulating the ligase activity, in order to complete the NHEJ mechanism and probably the $\mathrm{V}(\mathrm{D}) \mathrm{J}$ recombination process (Lees-Miller and Meek, 2003; Grawunder et al., 1997).
Interestingly, the MMTV endogenous retrovirus (accession no. BU515481, chromosome 19) is also present in this cluster and displayed overexpression in irradiated FTOCs. We have previously shown an association between the expression of MMTV and the parallel reduction of the TRBV8.1 rearranged segment in vivo during the thymus ontogeny of the CBA/J strain (Espanhol et al., 2003).

Finally, the DNA cross-link LR1 gene (DNA cross-link repair 1B, accession no. BC011094, chromosome 3F2.2), which codes for a protein involved in nucleotide excision repair, was induced in irradiated cultures. The deduced amino acid sequence of its coded protein was about $30 \%$ similar to that of the Artemis protein (Moshous et al., 2001) and its expression pattern was similar to that of genes implicated in $\mathrm{V}(\mathrm{D}) \mathrm{J}$ recombination, suggesting a possible role for this gene in this process.

In conclusion, our results showed for the first time that the FTOC model system reproduces the in vivo development of the thymus regarding TRBV8.1-BD2.1 V(D)J recombination.

Ionizing radiation, a potent physical agent capable of inducing DNA DSB, did not change the onset of recombination but increased the amount of the TRBV8.1-BD2.1 rearranged segment, suggesting a modulation of genes involved in such process.

The hybridization signatures obtained with cDNA microarrays permitted the identification of genes modulated during gamma irradiation of FTOCs. Among them, we found some genes related to the $\mathrm{V}(\mathrm{D}) \mathrm{J}$ recombination mechanism and we were able to pinpoint the DNA cross-link LR1 gene (DNA cross-link repair 1B) whose deduced protein sequence is similar to that of the Artemis protein, and the RUNX3 and SOX 4 genes whose coded proteins bind to the enhancers of $\mathrm{T}$-cell receptor genes.

The present data obtained by application of the cDNA microarray method indicated several genes participating in the mechanism of $\mathrm{V}(\mathrm{D}) \mathrm{J}$ recombination and while some genes are novel candidates, some others are important components for the repair of DSB via NHEJ, thus strongly suggesting an overlap between the two processes. These results open new perspectives for further studies on the specific roles of these genes, using strategies of gene silencing, such as RNA interference.

\section{Acknowledgements}

This research was supported by the Brazilian agencies Fundação de Amparo à Pesquisa do Estado de São Paulo (Fapesp, \#99/12135-9) and Conselho Nacional de Desenvolvimento Científico e Tecnológico (CNPq) and is part of the $\mathrm{PhD}$ thesis of RSC who received a pre-doctoral fellow from Fapesp (\#00/09994-9). We would like to thank Mrs. Geneviève Victorero, Mrs. Beatrice Loriod and Mr. Fabrice Lopez, Unité INSERM ERM 206, Marseille, France, for technical assistance and discussions. 


\section{References}

Bertucci, F., Houlgatte, R., Granjeaud, S., et al., 2002. Prognosis of breast cancer and gene expression profiling using DNA arrays. Ann. N. Y. Acad. Sci. 975, 217-231.

Chaudhuri, J., Alt, F.W., 2004. Class-switch recombination: interplay of transcription, DNA deamination and DNA repair. Nat. Rev. Immunol. 4, 541-552.

DeLuca, D., Bluestone, J.A., Schultz, L.D., Sharrow, S.O., Tatsumi, Y., 1995. Programmed differentiation of murine thymocytes during fetal thymus organ culture. J. Immunol. Methods 178, 13-29.

Eisen, M., Spellman, P., Brown, P., Botstein, D., 1998. Cluster analysis and display of genome-wide expression patterns. Proc. Natl. Acad. Sci. U.S.A. 95, 14863-14868.

Espanhol, A.R., Cardoso, R.S., Junta, C.M., Victorero, G., Loriod, B., Nguyen, C., Passos, G.A.S., 2004. Large scale gene expression analysis of $\mathrm{CBA} / \mathrm{J}$ mouse strain fetal thymus using cDNA-array hybridizations. Mol. Cell. Biochem. 260, 65-68.

Espanhol, A.R., Macedo, C., Junta, C.M., Cardoso, R.S., Victorero, G., Loriod, B., Nguyen, C., Jordan, B., Passos, G.A.S., 2003. Gene expression profiling during thymus ontogeny and its association with TCRVB8.1-DB2.1 rearrangements of inbred mouse strains. Mol. Cell. Biochem. 252, 223-228.

Fink, P.J., McMahan, C.J., 2000. Lymphocytes rearrange, edit and revise their antigen receptors to be useful yet safe. Immunol. Today 21, 561-566.

Fugmann, S.D., 2002. Breaking the seal. Nature 416, 691-694.

Gontijo, A.M.M.C., Green, C.M., Almouzni, G., 2003. Repairing DNA damage in chromatin. Biochimie 85, 1133-1147.

Grawunder, U., Wilm, M., Wu, X., Kuleska, P., Wilson, T.E., Mamm, M., Lieber, M.R., 1997. Activity of DNA ligase IV stimulated by complex formation with XRCC4 protein in mammalian cells. Nature 388, 492-495.

Hempel, W.M., Stanhope-Baker, P., Mathieu, N., Huang, F., Schlissel, M.S., Ferrier, P., 1998. Enhancer control of V(D)J recombination at the TCR beta locus: differential effects on DNA cleavage and joining. Genes Dev. 12, 2305-2317.

Jeggo, P., Concannon, P., 2001. Immune diversity and genomic stability: Opposite goals but similar paths. J. Photochem. Photobiol. 65, 88-96.

Junta, C.M., Passos, G.A.S., 1998. Emergence of TCR V(D)J recombination and transcription during ontogeny of inbred mouse strains. Mol. Cell. Biochem. 187, 67-72.

Lees-Miller, S.P., Meek, K., 2003. Repair of DNA double strand breaks by non-homologous end joining. Biochimie 85, 1161-1173.

Lefranc, M.P., Lefranc, G., 2001. The T-cell Receptors Facts Book, first ed. Academic Press Suffolk, London.
Macedo, C., Junta, C.M., Passos, G.A.S., 1999. Onset of T-cell receptor VB8.1 and DB2.1 V(D)J recombination during thymus development of inbred mouse strains. Immunol. Lett. 69, 371-373.

Magalhães, D.A.R., Macedo, C., Junta, C.M., Mello, S.S., Marques, M.M.C., Cardoso, R.S., Sakamoto-Hojo, E.T., Donadi, E.A., Passos, G.A.S., 2005. Hybridization signatures during thymus ontogeny reveals modulation of genes coding for T-cell signaling proteins. Mol. Immunol. 42, 1043-1048.

Moshous, D., Callebaut, I., Chasseval, R., Corneo, B., Cavazzana-Calvo, M., Le Deist, F., Tezcan, I., Sanal, O., Bertrand, Y., Philippe, N., Fischer, A., De Villartay, J.P., 2001. Artemis, a novel DNA doublestrand break repair/V(D)J recombination protein, is mutated in human severe combined immune deficiency. Cell 105, 177-186.

Muegge, K., Vila, M.P., Durum, S.K., 1993. Interleukin-7: a cofactor for V(D)J rearrangement of the T-cell receptor gene. Science 261, 93-95.

Nguyen, C., Rocha, D., Granjeaud, S., Baldit, M., Bernard, K., Naquet, P., Jordan, B.R., 1995. Differential gene expression in the murine thymus assayed by quantitative hybridization of arrayed cDNA clones. Genomics 29, 207-216.

Pastwa, E., Blasiak, J., 2003. Non-homologous DNA end joining. Acta Biochim. Pol. 50, 891-908.

Prise, K.M., Pinto, M., Newman, H.C., Michael, B.D., 2001. A review of studies of ionizing radiation-induced double-strand break clustering. Radiat. Res. 156, 572-576.

Quackenbush, J., 2002. Microarray data normalization and transformation. Nat. Genet. 32 (Suppl.), 496-501.

Rugh, R., 1968. The Mouse. Its Reproduction and Development. Burgess Publishing Company.

Schlissel, M., Constantinesai, A., Morrow, T., Baxter, M., Peng, A., 1993. Double-strand signal sequence breaks in V(D)J recombination are blunt $5^{\prime}$-phosphorylated, RAG-dependent, and cell-cycle regulated. Genes Dev. 7, 2520-2532.

Sollof, R.S., Wang, T.G., Dempsey, D., Jennings, S.R., Wolcott, R.M., Chervenak, R., 1997. Interleukin 7 induces TCR gene rearrangement in adult marrow-resident murine precursor T cells. Mol. Immunol. 34, 453-462.

Tapias, A., Auriol, J., Forget, D., Enzlin, J.H., Scharer, O.D., Coin, F., Coulombe, B., Egly, J.M., 2004. Ordered conformational changes in damaged DNA induced by nucleotide excision repair factors. J. Biol. Chem. 279, 19074-19083.

Toki, J., Adachi, Y., Jin, T., Fan, T., Takase, K., Lian, Z., Hayashi, H., Gershwin, M.E., Ikehara, S., 2003. Enhancement of IL-7 following irradiation of fetal thymus. Immunobiology 207, 247-258.

Verdeil, G., Puthier, D., Nguyen, C., 2002. Gene profiling approach to establish the molecular basis for partial versus full activation of naïve CD8 T lymphocytes. Ann. N. Y. Acad. Sci. 975, 68-76. 


\title{
Hybridization signatures during thymus ontogeny reveals modulation of genes coding for T-cell signaling proteins
}

\author{
Danielle A.R. Magalhães ${ }^{\mathrm{a}}$, Claudia Macedo ${ }^{\mathrm{a}}$, Cristina M. Junta ${ }^{\mathrm{a}}$, Stephano S. Mello ${ }^{\mathrm{b}}$, \\ Márcia M.C. Marques ${ }^{\mathrm{a}}$, Renato S. Cardoso ${ }^{\mathrm{a}}$, Elza T. Sakamoto-Hojo ${ }^{\mathrm{b}}$, \\ Eduardo A. Donadi ${ }^{\mathrm{c}}$, Geraldo A.S. Passos ${ }^{\mathrm{a}, \mathrm{d}, *}$ \\ ${ }^{a}$ Molecular Immunogenetics Group, Department of Genetics, Faculty of Medicine, University of São Paulo (USP), 14040-900 Ribeirão Preto, SP, Brazil \\ ${ }^{\mathrm{b}}$ Laboratory of Cytogenetics and Mutagenesis, Department of Genetics, Faculty of Medicine, USP, 14040-900 Ribeirão Preto, SP, Brazil \\ ${ }^{\mathrm{c}}$ Department of Medicine, Faculty of Medicine, USP, 14040-900 Ribeirão Preto, SP, Brazil \\ d Discipline of Genetics (DMEF), Faculty of Dentistry, USP, 14040-900 Ribeirão Preto, SP, Brazil
}

Received 18 August 2004; accepted 29 September 2004

Available online 23 November 2004

\begin{abstract}
Non-manipulated inbred mouse strains constitutes an interesting model-system for in vivo studies on thymus ontogeny due to the possibility to observe the molecular events of the thymocyte maturation. In previous studies, using RT-PCR method, we have found that several immune system genes such as interleukins and MHC are differentially expressed during ontogeny of the thymus whose genes act as modulators of T-cell differentiation. To determine which other genes are modulated on a large-scale basis, we measured the levels of mRNA expression in mouse fetal thymus (14-17 days of gestation) by hybridization with cDNA microarrays containing 1,576 cDNA sequences derived from the IMAGE MTB library. T-cell maturation was monitored by detection of the T-cell receptor beta TRBV8.1-BD2.1 rearranged DNA segment. Each developmental phase of thymus, displayed a characteristic expression profile, as evaluated by the Cluster and Tree-View softwares. Genes differentially and significantly expressed were selected on the basis of significance analysis of the microarray data (SAM program). With the reclustering of only significantly expressed genes, it was possible to characterize the phases of thymus ontogeny, based on the differential profile of expression. Our method provided the detection of genes implicated in the cell signaling, such as the hematopoietic cell signal transducer gene, genes implicated in T-cell calcium influx (tyrosine phosphatase) and calcium signaling proteins (vesicle transport binding protein 3, proline rich Gla, casein kinase alpha 1 and Down syndrome homolog protein 1) and a gene important for the protein transport, including T-cell receptors chains, towards the cell membrane (Golgi SNAP receptor complex member 2). The results demonstrate that the cDNA microarray used to explore the gene expression was useful for understanding the modulation of several cell-signaling genes, including the calcium cascade pathway, which is important for individual stages of T-cell maturation and control of anergy during thymus ontogeny. (c) 2004 Elsevier Ltd. All rights reserved.
\end{abstract}

Keywords: Thymus ontogeny; T-cell signaling; cDNA microarrays; Gene expression profiling; Cluster analysis

\section{Introduction}

The differentiation of thymocytes to mature T-cells occurs within the fetal thymus and all developmental stages are distinguishable by their expression of combination of CD cellsurface markers. This is a highly modulated phenomenon,

\footnotetext{
* Corresponding author. Tel.: +55 16602 3030; fax: +55 166330069

E-mail address: passos@ rge.fmrp.usp.br (G.A.S. Passos).
}

whose central molecular machinery is formed by the recombinase complex (RAG-1 and RAG-2) directly implicated in the $\mathrm{V}(\mathrm{D}) \mathrm{J}$ recombination of T-cell receptor gene segments (TRA, TRB, TRG and TRD) (Lefranc and Lefranc, 2001). The occurrence of the $\mathrm{V}(\mathrm{D}) \mathrm{J}$ reaction is important for triggering the maturation of T-cells and is also regulated by several other gene products such as interleukins (Fink and McMahan, 2000; Fugmann, 2002; Muegge et al., 1993; Sollof et al., 1997). 
The timing of T-cell maturation during thymus ontogeny is different among inbred mouse strains, strongly suggesting a role for the genetic background in the modulation of this phenomenon (Junta and Passos, 1998; Macedo et al., 1999).

Using the reverse-transcription-PCR (RT-PCR) method we have previously found that several immune system-related genes such as interleukins and the major histocompatibility complex (MHC) are differentially expressed during thymus ontogeny of inbred mouse strains (Espanhol et al., 2003).

Although the knockout mice have been used as a valuable tool for defining the role of a set of immune system-related genes (Mak et al., 2001), non-manipulated mouse strains still constitute a classical model-system useful for studies on the in vivo modulation of several other genes acting in cascade during thymocyte development.

The new functional genomic technology using the cDNA microarray method provides the opportunity to perform a comparative analysis between the different phases of the thymus ontogeny, yielding quantitative expression data of hundreds or thousands of genes in a single experiment.

The early fetal thymus has homogeneous cell populations composed of double negative (DN) thymocytes, whose proportion changes to double positive (DP) in the late stages of fetal development. In contrast, the newborn and adult thymus is the place of arrival of new colonizing precursors, which contribute to the formation of heterogeneous cell populations including macrophages and dendritic cells (Shortman and $\mathrm{Wu}, 1996)$.

In this study, we evaluated the dynamic transcriptional profile of thymus development observed during the gestational period of (Balb-c $\times$ C57Bl/6) $F_{1}$ hybrid mice using a set of two nylon cDNA microarrays containing a total of 1,576 thymus IMAGE sequences. Each phase of thymus development exhibited a characteristic gene expression pattern involving genes of known functions, permiting the identification of those implicated in the T-cell signaling pathway and expressed sequence tags (ESTs) whose functions are still unknown. The differentially and significantly expressed genes and ESTs observed here may be considered as novel markers characterizing individual stages of thymus ontogeny.

\section{Material and methods}

\subsection{Fetal thymus, RNA and DNA preparation}

The (Balb-c $\times \mathrm{C} 57 \mathrm{Bl} / 6) \mathrm{F}_{1}$ hybrid mice were obtained in our own animal facilities. Pregnant Balb-c females were sacrificed by ether inhalation and the fetuses were surgically collected from the uterus. The age of the fetus (in days post coitum, p.c.) was confirmed on the basis of the morphological characteristics of each development phase (Rugh, 1968).

Fetal thymus tissue (1 mg containing approximately $1 \times 10^{7}$ cells) was obtained by surgery under a stereomicroscope and immediately processed for total RNA and genomic
DNA extractions using Trizol ${ }^{\circledR}$ reagent, following the manufacturer's instructions (Invitrogen).

\subsection{TRBV8.1-BD2.1 recombination assay}

T-cell maturation was monitored by detection of rearrangements between segments TRBV8.1-BD2.1 during thymus development using PCR (Muegge et al., 1993). The oligonucleotide primers were the VB8.1 forward primer (primer 1, GAGGCTGCAGTCACCCAAAGTCCAA) the VB8.1 reverse primer (primer 2, ACAGAAATATACAGCTGTCTGAGAA), and the JB2.1 reverse primer (primer 3, TGAGTCGTGTTCCTGGTCCGAAGAA). The PCR reaction mixture contained $35 \mathrm{mM}$ Tris $(\mathrm{pH} 8.3), 50 \mathrm{mM} \mathrm{KCl}$, $2.5 \mathrm{mM} \mathrm{MgCl}_{2}$, bovine serum albumin $(100 \mu \mathrm{g} / \mathrm{ml})$, nucleotide triphosphates (NTPs) $(2 \mu \mathrm{M}$ each), the primers ( $0.5 \mu \mathrm{M}$ each), $1 \mathrm{U}$ Taq polymerase (Amersham Biosciences, Buckinghamshire, England), with a constant amount of genomic DNA $(1 \mu \mathrm{g})$ from each developmental stage. The PCR program consisted of 30 cycles $\left(1 \mathrm{~min}\right.$ at $94^{\circ} \mathrm{C}, 2.5 \mathrm{~min}$ at $54{ }^{\circ} \mathrm{C}$, and $1.5 \mathrm{~min}$ at $70^{\circ} \mathrm{C}$, with a 7 -min extension period).

The PCR product obtained with primers 1 and 3 was resolved on 1.2\% agarose gel and blotted on Hybond Nylon + (Amersham Biosciences). The rearranged VB8.1DB2.1 330 bp segment was detected by Southern hybridization with the ${ }^{32} \mathrm{P}$-labeled PCR product of $100 \mathrm{bp}$ obtained with primers 1 and 2, and visualized using a phosphor imager system (Cyclone, Packard Co. USA).

\section{3. cDNA-microarray method}

We used a pair of cDNA microarrays containing a total of 1,576 clones in the form of PCR products, spotted in duplicate on $2.5 \times 7.5 \mathrm{~cm}$ Hybond $\mathrm{N}+$ nylon membranes (Amersham Biosciences). The arrays were prepared in our laboratory using a Generation III Array Spotter (AmershamMolecular Dynamics). A complete file providing all genes present in the microarrays used in this study is available on line at http://rge.fmrp.usp.br/passos/nylon_array/mtb1.

Mouse EST cDNA clones were obtained from the Soares thymus 2NbMT normalized library, prepared from a C57B1/6J 4-week-old male thymus, and available in the I.M.A.G.E. Consortium (http://image.llnl.gov/image/html/ iresources.shtml).

cDNA inserts were homogeneous in size (near $1 \mathrm{~Kb}$ ) and cloned in three vectors (pT7T3D, pBluescript and Lafmid) and were amplified in 384- or 96-well plates using vector-PCR amplification with the following primers, which recognize the three vectors, LBP $1 \mathrm{~S} 5^{\prime}$-GTGGAATTGTGAGCGGATACC- $3^{\prime}$ forward and LBP 1AS $5^{\prime}$ GCAAGGCGATTAAGTTGG- $3^{\prime}$ reverse.

The membranes were first hybridized with the LBP $1 \mathrm{AS}\left[\gamma_{-}{ }^{33} \mathrm{P}\right] \mathrm{dCTP}$ (Amersham Biosciences) labeled oligonucleotide (vector hybridization). Quantification of the obtained signals allowed the estimation of the amount of DNA 
deposited in each spot. After stripping, the membranes were subsequently used for hybridization with cDNA complex probes (sample hybridization).

The characterization of each cDNA sequence was updated using the Eloge ${ }^{\circledR}$ (Ipsogen, France, www.ipsogen. fr) software, which runs in our local server and links each clone ID with the genome data banks (GenBank, www.ncbi. nlm.ih.gov and S.O.U.R.C.E., http://genome-www5. stanford.edu/cgi-bin/source/sourceSearch), allowing a set of information such as sequence, biological and molecular functions, chromosomal location, percent identity with humans and expression in different tissues.

\subsection{Complex $c D N A$ probe preparation and hybridization}

In this study, we refer to the radioactive cDNA originated from the thymus RNA samples as complex probe and the PCR product originated from the clones and deposited on the nylon microarrays as target.

The ${ }^{33} \mathrm{P}$-labeled cDNA complex probes were prepared by reverse transcription of $10 \mu \mathrm{g}$ of thymus total RNA using oligo $\mathrm{dT}_{12-18}$ as primer. One hundred microliters of ${ }^{33} \mathrm{P}-$ cDNA complex probe containing 30-50 million cpm was hybridized with nylon microarrays as previously described (Bertucci et al., 2002; Nguyen et al., 1995; Verdeil et al., 2002).

\subsection{Imaging acquisition}

We used imaging plates and a phosphor imager (Cyclone, Packard Instruments, USA) to capture the hybridization signals and the Array Vision ${ }^{\circledR}$ (Imaging Research Inc. USA) to quantify the signals with local background subtraction, whose spots were matched with a template grid.

The ratio between vector probe hybridization values and complex probe hybridization values for each spot was used as reference normalization value. We employed also total intensity normalization, using the median expression value (Quackenbush, 2002).

\section{6. cDNA-microarray data analysis}

The gene expression data analyzed here were obtained from three independent determinations for each day of fetal development.

We used the SAM method (Significance Analysis of Microarrays available at http://www-stat.stanford. edu/ tibs/SAM/index.html) Tusher et al. (2001) to analyze the significant variations in the gene expression. This method is based on $t$-test statistics, specially modified to high throughput analysis. The significant variations in the gene expression of the developing thymus were compared with the 14 days p.c. (14 versus 15,14 versus 16 and 14 versus 17 days of gestation). The program calculates a global error chance, the false discovery rate (FDR) and a gene error chance ( $q$-value).

\subsection{Hierarchical clustering}

We used a hierarchical clustering algorithm, comparing means of different genes whose standard deviation did not overlap, whose objective was to compute a dendrogram that assembles all elements into a single tree. The software for this algorithm can be obtained from the author (http://rana.stanford.edu/clustering) (Eisen et al., 1998). Before clustering, the gene expression values were median-centered and converted to log. We used the Pearson correlation distance metrics and average linkage for clustering organization.

From the 1,576 sequences present on the microarrays, 315 (20\%) were excluded from the calculations by the software due to their low statistical significance (in this case were analyzed 1,261 sequences, including 200 named genes and 1,061 ESTs).

In order to cluster only genes whose expression values were significant, we used the values for the induced and repressed genes detected by the SAM method.

\section{Results}

\subsection{Monitoring thymocyte maturation}

The detection of the T-cell receptor TRBV8.1-BD2.1 rearranged DNA segment served as an indication of thymocyte maturation during the fetal development of the thymus. We detected the onset of TRBV8.1 V(D)J recombination at 14 days gestation in the heterozygous (Balb-c $\times \mathrm{C} 57 \mathrm{~B} 1 / 6) \mathrm{F}_{1}$ fetuses whose amount of the rearranged DNA fragment increased during thymus ontogeny (Fig. 1).

\subsection{Hierarchical clustering of significant genes}

The hierarchical cluster analysis, computing all the 1,261 sequences and probes from thymi of fetuses of different

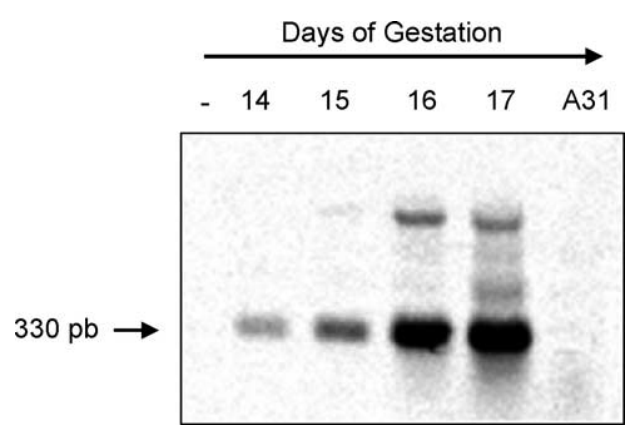

Fig. 1. Detection of the recombined TRBV8.1-BD2.1 segment in genomic DNA during thymus ontogeny of (Balb-c $\times \mathrm{C} 57 \mathrm{Bl} / 6) \mathrm{F}_{1}$ hybrid mice. $(-)=$ PCR without DNA, A31 $=$ murine $\mathrm{Balb} / 3 \mathrm{~T} 3$ derived fibroblast cell line DNA. 


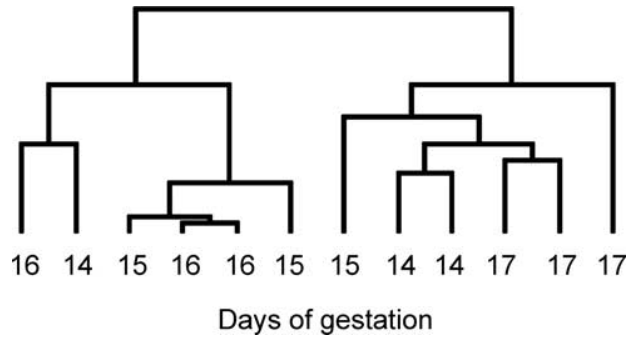

Fig. 2. Clustering samples of each day of thymus gestation of the (Balb$\mathrm{c} \times \mathrm{C} 57 \mathrm{~B} 1 / 6) \mathrm{F}_{1}$ hybrid mice considering the raw normalized expression data of the 1,261 genes. (www.rge.fmrp.usp.br/passos/TRBV81/cluster1261).

ages p.c., showed that there is variability in the patterns of gene expression of the thymus within mice for each day of gestation. This variability caused shuffling in the clustering of the RNA samples (cDNA probes) of fetuses (Fig. 2) (www.rge.fmrp.usp.br/passos/TRV81/cluster1261). We used the approach of clustering the significant genes proposed by the SAM program, i.e. only those induced or repressed genes whose variability was statistically significant. This approach successfully distinguished the samples of thymi according to days of gestation (Fig. 3) (www.rge.fmrp.usp.br/passos/TRBV81/reclustering/SAM).

\subsection{Genes differentially expressed in the developing thymus}

To identify significant changes in gene expression during fetal development of the thymus, we compared the stage when the onset of TRBV8.1 recombination occurs, at 14 days of gestation, with those observed on the subsequent days (14 versus 15,14 versus 16 and 14 versus 17 days p.c.). We used a scatter plot of the observed relative difference $d(i)$ versus the expected relative difference $d_{E}(i)$ as shown by the SAM program.

Most of the 1,261 genes tested presented $d(i) \cong d_{E}(i)$, i.e. their expression pattern did not change; however, some genes were significantly induced or repressed during thymus development (Table 1) (www.rge.fmrp.usp.br/passos/TRBV81/ SAM/table1).
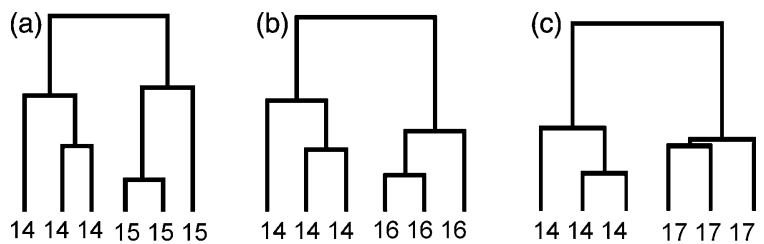

Days of gestation

Fig. 3. Reclustering samples of each day of thymus gestation of (Balb$\mathrm{c} \times \mathrm{C} 57 \mathrm{Bl} / 6) \quad \mathrm{F}_{1}$ hybrid mice considering only the significant expressed genes reported by the SAM program. (a) 14 vs. 15 , (b) 14 vs. 16 and (c) 14 vs. 17 days of gestation. (www.rge.fmrp.usp.br/passos/TRBV81/reclustering/ SAM).
Table 1

Number of genes differentially expressed during thymus development of $\left(\right.$ Balb-c $\times$ C57Bl/6) $F_{1}$ hybrid mice as reported by the SAM program ${ }^{\mathrm{a}}$

\begin{tabular}{llll}
\hline $\begin{array}{l}\text { Thymus development } \\
\text { (in days p.c.) }\end{array}$ & \multicolumn{2}{l}{ Significant genes } & FDR \\
\cline { 2 - 3 } & Induced & Repressed & \\
\hline $14-15$ & 31 & 73 & 48 \\
$14-16$ & 16 & 47 & 22 \\
$14-17$ & 18 & 21 & 64 \\
\hline
\end{tabular}

${ }^{a}$ Complete file of gene names available online (www.rge.fmrp.usp. br/passos/TRBV81/SAM/table1), FDR = false discovery rate (median).

\section{Discussion}

The aim of the present study was to perform a comparative large-scale gene expression analysis of thymocyte maturation during ontogeny of the thymus of (Balb-c $\times \mathrm{C} 57 \mathrm{Bl} / 6) \mathrm{F}_{1}$ hybrid mice to gain new insights into the modulation of gene transcriptions which could be correlated with T-cell maturation.

In previous observations, we described the different timing of T-cell maturation first by means of detection of the onset of the T-cell receptor TRA and TRB V(D)J recombinations in Balb-c, C57B1/6 and CBA/J strains (Junta and Passos, 1998; Macedo et al., 1999) and second by showing that several immune system-related genes such as interleukins and MHC displayed a differential expression pattern among these strains during thymus ontogeny (Espanhol et al., 2003).

T-cell differentiation and all developmental stages within the thymus are distinguishable by the expression of CD cellsurface marker combination. The $\mathrm{V}(\mathrm{D}) \mathrm{J}$ recombination of the TRA/TRB and TRG/TRD segments is a central phenomenon defining the T-cell fate, which is mediated by recombinase complex from $R A G-1$ and $R A G-2$ genes and modulated by several other gene products (Muegge et al., 1993; Sollof et al., 1997).

In the present study we showed that the emergence of the TRBV8.1 rearrangement during fetal development of the heterozygous (Balb-c $\times \mathrm{C} 57 \mathrm{~B} 1 / 6) \mathrm{F}_{1}$ mouse thymus occurs on day 14 p.c., similar to the parental strain C57Bl/6 (Espanhol et al., 2003). This suggest a participation of the genetic background of the C57Bl/6 strain in the control of T-cell maturation.

Despite the relevance of transgenic and knock-out mice to immunological research, the classical inbred nonmanipulated mouse strains constitute a model-system for studies on the effects of different genetic backgrounds on the modulation of T-cell maturation. In recent years, our group has pursued this approach with the classical inbred strains (Espanhol et al., 2003, 2004; Junta and Passos, 1998; Macedo et al., 1999) and in the present study we are reporting the first large-scale hybridization signatures of the thymus of heterozygous mice resulted from the fusion of two inbred different genetic backgrounds.

Two approaches were used to analyze the large-scale gene expression profile of the developing thymus of $F_{1}$ hybrid 
mice, encompassing a previous analysis of the genes which were only differentially expressed (Cluster and Tree-View method), and a second analysis clustering only those genes which were differentially and significantly expressed (SAM and Cluster and Tree-View methods).

By exploring a large set of genes, we intended to identify novel differentially expressed genes that could be used as markers for the individual stages of thymus ontogeny.

However, the clustering of raw expression data using the set of 1,261 genes caused a shuffling among RNA samples (cDNA probes) from each day of gestation (Fig. 2).

Considering the possibility that the similarity between samples from two distant days of gestation, such as 14 and 17 days p.c., as seen in the dendrogram of Fig. 2, might not be statistically significant, we applied a second round of clustering, now using the differentially and significantly expressed genes. Using this approach, it was possible to distinguish the days of gestation (Fig. 3), demonstrating the importance, in this study, of a previous statistical treatment instead of using only raw normalized microarray data to run the Cluster and Tree-View method.

Reclustering showed that the constitution of the gene cluster diverged for each stage of thymus development, i.e. each cluster harbored different genes with different expression patterns.

The 14th day p.c. RNA sample was considered to be the test sample for comparisons with the subsequent days of gestation (14 versus 15,14 versus 16 and 14 versus 17 days p.c.); however, in a given cluster, the repressed genes in a given day of gestation presented as induced on the following day. This is evidence that the genes used for data reclustering may play a role in thymus ontogeny and may represent novel candidate genes participating in the control of T-cell maturation.

It was possible to point out seven genes implicated in cell signaling. The hematopoietic cell signal transducer gene, Hcst, (accession number NM011827, ID 640698) was induced in the early stages of thymus development (14-16 days p.c.) and repressed at 17 days p.c. The Hcst protein is located outside the plasma membrane and is implicated in the coupling of receptor stimulation to downstream activation of GTPases. As the maturation of the thymocytes within the thymus depends on the participation of other cell types, such as stroma (Gill et al., 2003), this could represent evidence for a role of the Hcst gene in cellular communication via molecular signaling in the early thymus.

Genes implicated in the calcium signaling pathway were also modulated, such as the proline-rich Gla (Gcarboxyglutamic acid) polypeptide 2 gene, Prrg2, (accession number NM022999, ID 640686), the Down syndrome critical region homolog 1 gene, Dscrl, (accession number NM019466, ID 640638), and the syntaxin binding protein 3 gene, Stxbp3, (accession number NM011504, ID 640484), whose proteins have a role in the inhibition of the calcium influx pathway via calcineurin. These genes were repressed in the early ( 15 days p.c.) and late (17 days p.c.) thymus. The casein kinase 1,alpha 1 gene, Csnklal (accession number
Table 2

Number of ESTs differentially expressed during thymus development of $\left(\right.$ Balb-c $\times$ C57B1/6) $\mathrm{F}_{1}$ hybrid mice as reported by the SAM program ${ }^{\mathrm{a}}$

\begin{tabular}{llll}
\hline $\begin{array}{l}\text { Thymus development } \\
\text { (in days p.c.) }\end{array}$ & \multicolumn{2}{l}{ Significant ESTs } & FDR \\
\cline { 2 - 3 } & Induced & Repressed & \\
\hline $14-15$ & 20 & 49 & 48 \\
$14-16$ & 10 & 30 & 22 \\
$14-17$ & 10 & 14 & 64 \\
\hline
\end{tabular}

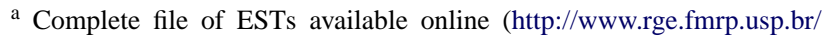
passos/TRBV81/SAM/table2), FDR = false discovery rate (median).

NM146087, ID 640022) whose protein is an inhibitor of calcineurin, was induced at 16 days p.c. These data, suggest that the calcium influx pathway could be activated in the thymus with 15 and 17 days p.c. and down-regulated with 16 days p.c.

All these genes above mentioned participates in the control of calcium influx pathway mediated by calcineurin, which is important in the activation of the nuclear factor of activated T-cells (NFAT), an transcription factor of T-cells.

As calcium signaling is implicated in the induction of Tcell anergy mediated through calcineurin and NFAT, our results could be useful to know the genes that induce tolerance (Feske et al., 2001, 2003; Heissmeyer et al., 2004).

The Golgi SNAP receptor complex member 2 gene, Gosr2, (accession number NM019650, ID 640152) was induced in the thymus from 15 to 17 days p.c. This gene has a role in the intracellular transport of newly synthesized proteins from the endoplasmic reticulum to their destination in the cell. Since we showed in this study that T-cells within the thymus begin to mature from 14 days p.c., the activation of the Gosr 2 gene in this phase is of particular importance due to the necessity of delivering the T-cell receptors chains on the cell surface.

Finally, we have shown that the protein tyrosine phosphatase 4a3 gene, Ptp4a3, (accession number NM008975, ID 640437), was induced in the thymus with 17 days p.c. There is evidence for a role of this gene in humans in colorectal cancer metastasis (Saha et al., 2001), i.e. cell migration. As the mature thymocytes should migrate from the thymus to blood stream, this may be evidence for the participation of the Ptp4a3 gene in the late stages of T-cell maturation including migration from the thymus.

The 133 EST sequences reclustered in the dendrograms of Fig. 3, whose functions were not yet assigned, presented a differential pattern of expression and were reclustered together with named genes (Table 2) (www.rge.fmrp.usp.br/passos/TRBV81/SAM/table2). This can be evidence for the participation of these ESTs in biological processes similar of those of the known genes. These ESTs are being studied by our group with the aim of associating their expression profile with gene function.

As the microarrays used in this study were prepared with thymus sequences, we explored their expression levels during the development of this organ. Although, the thymus harbors different cell types including macrophages and dendritic 
cells, we have found statistically significant expression of genes whose functions are associated with thymocytes.

The genes selected for discussion in this study may have a broader functions(s) during thymus development in cell types other than thymocytes. However, these aspects are still an open matter.

Taken together, our findings demonstrate that the cDNA microarrays and the bioinformatics programs employed here were useful tools to demonstrate the changes in the gene expression pattern of developing thymus which may reflect specific organ transcriptome programs.

\section{Acknowledgements}

This research was supported by the Brazilian agencies Fundação de Amparo à Pesquisa do Estado de São Paulo (Fapesp, 99/12135-9, 01/08278-0) and Conselho Nacional de Desenvolvimento Científico e Tecnológico (CNPq). We also would like to thank Drs. Catherine Nguyen and Remi Houlgatte and Mrs Beatrice Loriod and Geneviève Victorero from the Unité INSERM ERM 206, Marseille, France, for the help and discussions and for the IMAGE MTB cDNA mouse library clones used in this study.

\section{References}

Bertucci, F., Houlgatte, R., Granjeaud, S., et al., 2002. Prognosis of breast cancer and gene expression profiling using DNA arrays. Ann. N.Y. Acad. Sci. 975, 217-231.

Eisen, M., Spellman, P., Brown, P., Botstein, D., 1998. Cluster analysis and display of genome-wide expression patterns. Proc. Natl. Acad. Sci. U.S.A 95, 14863-14868.

Espanhol, A.R., Macedo, C., Junta, C.M., et al., 2003. Gene expression profiling during thymus ontogeny and its association with TRVB8DB2.1 rearrangements of inbred mouse strains. Mol. Cell Biochem. 252, 223-228.

Espanhol, A.R., Cardoso, R.S., Junta, C.M., et al., 2004. Large scale gene expression analysis of $\mathrm{CBA} / \mathrm{J}$ mouse strain fetal thymus using cDNA-array hybridizations. Mol. Cell. Biochem. 206, 65-68.
Feske, S., Giltnane, J., Dolmestsch, R., et al., 2001. Gene regulation mediated by calcium signals in $\mathrm{T}$ lymphocytes. Nat. Immunol. 2, 316-324.

Feske, S., Okamura, H., Hogan, P.G., et al., 2003. Ca2+/calcineurin signaling in cells of the immune system. Biochem. Biophys. Res. Commun. 311, 1117-1132.

Fink, P.J., McMahan, C.J., 2000. Lymphocytes rearrange, edit and revise their antigen receptors to be useful yet safe. Immunol. Today 21, 561-566.

Fugmann, S.D., 2002. Breaking the seal. Nature 416, 691-694.

Gill, J., Malin, M., Sutherland, J., et al., 2003. Thymic generation and regeneration. Immunol. Rev. 195, 28-50.

Heissmeyer, V., Macian, F., Im, S.H., et al., 2004. Calcineurin imposes T-cell unresponsiveness through targeted proteolysis of signaling proteins. Nat. Immunol. 5, 238-240.

Junta, C.M., Passos, G.A.S., 1998. Emergence of TCR- $\alpha \beta$ V(D)J recombination and transcription during thymus ontogeny of inbred mouse strains. Mol. Cell. Biochem. 187, 67-72.

Lefranc, M.P., Lefranc, G., 2001. The T-Cell Receptor Facts Book, first ed. Academic Press, Suffolk.

Macedo, C., Junta, C.M., Passos, G.A.S., 1999. Onset of T-cell receptor $\mathrm{V} \beta 8.1$ and $\mathrm{D} \beta 2.1 \mathrm{~V}(\mathrm{D}) \mathrm{J}$ recombination during thymus development of inbred mouse strains. Immunol. Lett. 69, 371-373.

Mak, T.W., Penninger, J.M., Ohashi, P.S., 2001. Knockout mice: a paradigm shift in modern immunology. Nat. Rev. Immunol. 1, 11-19.

Muegge, K., Vila, M.P., Durum, S.K., 1993. Interleukin-7: a cofactor for V(D)J rearrangement of the T-cell receptor gene. Science 261, 93-95.

Nguyen, C., Rocha, D., Granjeaud, S., et al., 1995. Differential gene expression in the murine thymus assayed by quantitative hybridization of arrayed cDNA clones. Genomics 29, 207-215.

Quackenbush, J., 2002. Microarray data normalization and transformation. Nat. Genet. Supp. 32, 496-501.

Rugh, R., 1968. The Mouse. Its Reproduction and Development, first ed. Burgess Publishing Company, Edina, MN, USA.

Saha, S., Bardelli, A., Buckhaults, P., et al., 2001. A phosphatase associated with metastasis of colorectal cancer. Science 294, 1343-1346.

Shortman, K., Wu, L., 1996. Early T lymphocyte progenitors. Annu. Rev. Immunol. 14, 29-47.

Sollof, R.S., Wang, T.G., Dempsey, D., et al., 1997. Interleukin-7 induces $T C R$ gene rearrangement in adult marrow-resident murine precursor T-cells. Mol. Immunol. 34, 453-462.

Tusher, V.G., Tibshirani, R., Chu, G., 2001. Significance analysis of microarrays applied to the ionizing radiation response. Proc. Natl. Acad. Sci. U.S.A 98, 5116-5121.

Verdeil, G., Puthier, D., Nguyen, C., 2002. Gene profiling approach to establish the molecular bases for partial versus full activation of naïve CD8 T lymphocytes. Ann. N.Y. Acad. Sci. 975, 68-76. 


\title{
Gene expression profiling during thymus ontogeny and its association with TCRV $\beta 8$.1-D $\beta 2.1$ rearrangements of inbred mouse strains
}

\author{
Aline R. Espanhol, ${ }^{1,2}$ Cláudia Macedo, ${ }^{1}$ Cristina M. Junta, ${ }^{1}$ \\ Renato Sousa Cardoso, ${ }^{1}$ Geneviève Victorero, ${ }^{3}$ Beatrice Loriod, ${ }^{3}$ \\ Catherine Nguyen, ${ }^{3}$ Bertrand Jordan ${ }^{3}$ and Geraldo A.S. Passos ${ }^{1,4}$ \\ ${ }^{1}$ Grupo de Imunogenética Molecular, Departamento de Genética, Faculdade de Medicina de Ribeirão Preto, Universidade \\ de São Paulo (USP), Ribeirão Preto; ${ }^{2}$ Universidade Federal de São Carlos, Programa de Genética e Evolução, São \\ Carlos, SP, Brasil; ${ }^{3}$ Unité INSERM Technologies Avancées pour le Génome et la Clinique, Marseille, France; ${ }^{4}$ Disciplina \\ de Genética, Faculdade de Odontologia de Ribeirão Preto, USP, Ribeirão Preto, SP, Brasil
}

Received 13 September 2002; accepted 17 February 2003

\begin{abstract}
The V(D)J recombination of TCR $\alpha$ and $\beta$ in early developing T-cells is a highly modulated phenomenon initiated and completed by recombinase complex (RAG-1 and RAG-2), and regulated by other gene products such as interleukins. To further evaluate the association of several other gene products with the evolution of TCRV $\beta 8.1 \mathrm{~V}(\mathrm{D}) \mathrm{J}$ rearrangements in vivo, the mRNA expression levels of seven interleukins, three cytokines, receptors TCRV $\beta 8.1$ and IL-2R $\beta$, MHC-I/MHC-II, RAG-1/ RAG-2 and retroviral superantigen MMTV(SW) were measured by RT-PCR during the fetal development of the thymus of three inbred mouse strains (Balb-c, C57Bl/6 and CBA/J). Clustering using the Tree View software, was used to organize these genes based on similarity of expression patterns. Each strain displayed a different expression profile during thymus ontogeny.

During the late developmental stage the most evident association was the kinetics of MMTV(SW) retrovirus, IL-2R $\beta$ and IL-7 overexpression with reduction of TCRV $\beta 8.1-\mathrm{D} \beta 2.1$ rearrangement in the thymus of CBA/J mice. These data suggest a susceptibility of this strain to expression of $\operatorname{MMTV}(\mathrm{SW})$ upon reduction of the rearranged TCRV $\beta 8.1$-D $\beta 2.1$ segment in developing thymocytes, with parallel IL-7 overexpression. (Mol Cell Biochem 252: 223-228, 2003)
\end{abstract}

Key words: TCRV $\beta 8.1, \mathrm{~V}(\mathrm{D}) \mathrm{J}$ recombination, gene expression profiling, cytokine, cluster analysis.

\section{Introduction}

Non-manipulated inbred mouse strains constitute a model system for studies on the effects of different genetic backgrounds on the in vivo maturation of thymocytes. In previous work, we have observed that onset of T-cell receptor $(\mathrm{TCR} \alpha / \beta) \mathrm{V}(\mathrm{D}) \mathrm{J}$ recombination differs among the Balb-c, C57B1/6 and CBA/J strains $[1,2]$.

The $\mathrm{V}(\mathrm{D}) \mathrm{J}$ recombination in early developing T-cells is a highly modulated phenomenon. The rearrangements of T-cell receptor genes (TCR $\alpha$ and $\beta$ ) is initiated and completed by the recombinase enzymatic complex (RAG-1 and RAG-2), but is regulated by other gene products such as interleukins $[3,4]$.

Stromal cells from the thymus or bone marrow are very important for development of T-cells producing cytokines [5, $6]$. In this context, interleukin (IL)-7 in particular appears to serve as a proliferative agent before and after gene rearrangements and possibly as a survival factor during rearrangements [7].

Address for offprints: G.A.S. Passos, Grupo de Imunogenética Molecular, Depto. de Genética, Faculdade de Medicina de Ribeirão Preto, SP, Brasil (E-mail: passos@ rge.fmrp.usp.br) 
Deletion of the IL-7 gene delays V(D)J recombination of the TCR $\beta, \gamma$ and $\delta$ loci during fetal development in mice [6]. Recent studies have shown that IL-7 plays a decisive role in thymus maturation and T-cell differentiation modulating TCR $\alpha / \beta$ and $\gamma / \delta$ locus accessibility to the $\mathrm{V}(\mathrm{D}) \mathrm{J}$ recombinase $[8,9]$.

The function of T-cell receptors $(\mathrm{TCR} \alpha / \beta)$ is related to the recognition of a processed non-self antigen together with a self molecule of class I or class II MHC. It is plausible to consider that these molecules expressed in the thymus environment may play a role in T-cell maturation [10].

The TCR $\beta$ receptor is of particular interest because there is evidence for its essential role in TCR $\alpha / \beta$ differentiation. Thymuses of mice with a mutation in TCR genes contain 10fold fewer cells than thymuses of wild-type mice and $50 \%$ of these cells are double positive, indicating that the recombination and/or expression of TCR $\beta$ is required for maturation [11]. Moreover, the TCR $\beta$ enhancer controls the recombinations of its own locus [12].

To further evaluate the association of several other gene products with the evolution of TCRV $\beta 8.1 \mathrm{~V}(\mathrm{D}) \mathrm{J}$ rearrangements in vivo, the mRNA expression levels of seven interleukins (IL-1 $\alpha$, IL-1 $\beta$, IL-2, IL-3, IL-4, Il-6, IL-7), three cytokines (TNF- $\beta$, IF- $\gamma$ and GM-CSF), receptors IL-2R $\beta$ and TCRV $\beta 8.1$, MHC-I and MHC-II, RAG- 1 and RAG-2 and retroviral superantigen $\mathrm{MMTV}(\mathrm{SW})$ were measured by RTPCR during the in vivo fetal development of the thymus of three inbred mouse strains (Balb-c, C57Bl/6 and CBA/J).

The expression profiles were examined using the Gene Cluster method and visualized with the TreeView software $[13,14]$. The inbred strains displayed distinct gene expression signatures.

These data, when compared with the evolution of TCRV $\beta 8.1$ rearrangements, which were also distinct among strains, permitted a direct visualization of the effect of genetic background on the modulation of $\mathrm{V}(\mathrm{D}) \mathrm{J}$ recombination.

\section{Materials and methods}

\section{TCRV $\beta 8.1-D \beta 2.1 \mathrm{~V}(D) J$ recombination assay}

Rearrangements between segments TCRV $\beta 8.1-D \beta 2.1$ during thymus development were investigated by PCR as previously described [3]. The oligonucleotide primers used were the V $\beta 8.1$ forward primer (primer 1, GAGGCTGCAGTCACCCAAAGTCCAA) the V $\beta 8.1$ reverse primer (primer 2, ACAGAAATATACAGCTGTCTGAGAA) and the J $\beta 2.1$ reverse primer (primer 3, TGAGTCGTGTTCCTGGTCCGAAGAA). The PCR reaction mixture contained $35 \mathrm{mM}$ TRIS (pH 8.3), $50 \mathrm{mM} \mathrm{KCl}, 2.5 \mathrm{mM} \mathrm{MgCl}$, bovine serum albumin $(100 \mu \mathrm{g} /$ $\mathrm{ml})$, nucleotide triphosphates (NTPs) $(2 \mu \mathrm{M}$ each), the primers $(0.5 \mu \mathrm{M}$ each), $1 \mathrm{U}$ Taq polymerase (Amersham Bio- sciences), with a constant amount of genomic DNA ( $1 \mu \mathrm{g})$ from each developmental stage. The PCR program consisted of 30 cycles $\left(1 \mathrm{~min}\right.$ at $94^{\circ} \mathrm{C}, 2.5 \mathrm{~min}$ at $54^{\circ} \mathrm{C}$, and $1.5 \mathrm{~min}$ at $70^{\circ} \mathrm{C}$, with a 7-min extension period). The PCR product obtained with primers 1 and 3 was resolved on $1.2 \%$ agarose gel and blotted on Hybond Nylon + (Amersham Biosciences). The rearranged V $\beta 8.1-\mathrm{D} \beta 2.1330 \mathrm{bp}$ segment was detected by Southern hybridization with the ${ }^{32} \mathrm{P}$-labeled $\mathrm{PCR}$ product of $100 \mathrm{bp}$ obtained with primers 1 and 2 and quantified using a phosphor imager system (Cyclone, Packard Co., USA) and the OptiQuant ${ }^{\circledR}$ software.

\section{Reverse transcription-PCR (RT-PCR)}

The gene transcriptions were quantified with cDNA prepared from total thymus RNA.

Balb-c, C57Bl/6 and CBA/J mice were mated by isogenic crosses, pregnant females were sacrificed by ether inhalation and fetuses surgically collected from the uterus. The age of the fetuses (as days p.c.) was confirmed on the basis of the morphological characteristics of each phase of development [15].

Thymus tissue (one milligram containing approximately $1 \times 10^{7}$ cells) from fetuses at different developmental stages (14-17 days p.c.) and from new born pups and adults was obtained by surgery under a stereomicroscope and immediately processed for total RNA using Trizol ${ }^{\circledR}$ reagent (Invitrogen).

The cDNA samples were obtained by reverse transcription from thymus total RNA using the Super Script II enzyme and oligo $\mathrm{dT}_{12-18}$ to prime the reaction according to the instructions of Invitrogen. The cDNA was used as template for PCR (RT-PCR) using the primers for genes listed in Table 1. The PCR mixture was as described for the $V(D) J$ recombination assay with a constant amount of cDNA from each developmental stage. The PCR program consisted of one cycle at $94^{\circ} \mathrm{C}$ for $1 \mathrm{~min}, 30$ cycles $\left(1 \mathrm{~min}\right.$ at $94^{\circ} \mathrm{C}, 1 \mathrm{~min}$ at $60^{\circ} \mathrm{C}(\mathrm{ex}-$ cept for IL- $1 \alpha$ at $\left.55^{\circ} \mathrm{C}\right), 1 \mathrm{~min}$ at $72^{\circ} \mathrm{C}$ ), and a 1 -min extension period.

These conditions permitted proportional amplifications according the expression levels, enough to be detected by the oligonucleotide hybridizations and quantified using the phosphorimager system.

The RT-PCR products were blotted on nylon Hybond N+ (Amersham Pharmacia Biotech) using a 96 well Hybri-Dot Manifold (Life Technologies, Inc.). The mRNA expression levels were detected by hybridization with ${ }^{33} \mathrm{P}$-labeled specific oligonucleotides internal to each cDNA (Table 1), except for TCRV $\beta 8.1$, RAG-1 and RAG-2, MHC-I and MHC-II, whose probes were the ${ }^{32} \mathrm{P}$ labeled $\mathrm{PCR}$ product obtained with forward and reverse primers and quantified using the phosphor storage system as mentioned above. The values were normalized on the basis of $\beta$-actin expression in each total RNA sample. 
Table 1. Target cDNA sequences amplified by RT-PCR, oligonucleotide primers and probes ${ }^{\mathrm{a}}$

\begin{tabular}{llll}
\hline Target & Forward primer & Reverse primer & Internal probe \\
\hline IL-1 $\alpha$ & TTACAGTGAAAACGAAGA & TGTTTGTCCACATCCTG & GAGAACCTCTGAAACGTC \\
IL-1 $\beta$ & GCAACTGTTCCTGAACTC & CTCGGAGCCTGTAGTGCA & ATTGTGGCTGTGGAGAA \\
IL-2 & AACAGCGCACCCACTTCAA & TTGAGATGATGCTTTGACA & GTTCATCTTCTAGGCACTG \\
IL-3 & GCCAGCTCTACCACCAGCA & AACATTCCACGGTTCCACG & AGGTTCTGGGAGCTTCCC \\
IL-4 & TAGTTGTCATCCTGCTCTT & CTACGAGTAATCCATTTGC & GATGATCTCTCTCAAGTG \\
IL-6 & TTCCTCTCTGCAAGAGACT & TGTATCTCTCTGAAGGACT & CATTTCCACGATTTCCCA \\
IL-7 & ACATCATCTGAGTGCCACA & CTCTCAGTAGTCTCTTTAG & TGCCTTGTGATACTGTTAG \\
TNF- $\beta$ & TCAGAAGCACTTGACCCAT & AAGTCCCGGATACACAGACT & CAAAGTAGAGGCCACTGG \\
IF- $\gamma$ & AACGCTACACACTGCATCT & TGCTCATTGTAATGCTTGG & TCGCCTTGCTGTTGCTGT \\
GM-CSF & TTCCTGGGCATTGTGGTCT & TGGATTCAGAGCTGGCCTGG & ACCTCTTCATTCAACGTG \\
IL2-R $\beta$ & CCAGCTGCTTCACCAACCA & AGAAGAGCAGCAGGTCATC & CCTGCCAGGTGTACTT \\
RAG-1 & ATGGCTGCCTCCTTGCCGTCT & GTATCTCCGGCTGTGCCCGTC & ---------- \\
RAG-2 & ATGTCCCTGCAGATGGTAACA & TAAATCTTATCGGAAAGCTCA & ----------- \\
MHC-I & GGGGATGGAACCTTCCAGAAGTG & CACAAAAGCCACCACAGCTCCA & ---------- \\
MHC-II & CGACTGTAGAACCTTAGCCTG & GTGGACACAATTCCTGTTTT & --------- \\
MMTV & GTAGACCTAATTGTATTTATAAATGTT & GGACTTATAGGGGACCTTACAT & TGCTATAGCTCCCTCCCTCTTCG \\
$\beta-A C T I N$ & ATGGATGACGATATCGCT & ATGAGGTAGTCTGTCAGGT & AGCAAGAGAGGTATCCT \\
\hline
\end{tabular}

aProbes for cytokines, $\beta$-actin and MHC-I and MHC -II see ref. [26]; for RAG-1 and RAG-2 see [27] and for MMTV see [28].

\section{Hierarchical clustering}

The gene expression data analyzed here were collected, from three independent determinations, on blotted RT-PCR of several gene products from different developmental stages of the thymus of Balb-c, C57B1/6 and CBA/J strains. We used a hierarchical clustering algorithm, comparing means of different genes whose standard deviation do not overlaps and, whose objective, is to compute a dendrogram that assembles all elements into a single tree. The software for this algorithm can be obtained from the author http://rana.stanford.edu/clustering $[13,14]$.

\section{Results}

Quantification of TCRV $\beta 8.1$ rearrangement in developing thymus

We detected temporal and quantitative differences in the onset of $\mathrm{V}(\mathrm{D}) \mathrm{J}$ recombination of TCRV $\beta 8.1-\mathrm{D} \beta 2.1$ DNA segments among the strains studied.

The Balb-c strain started recombination at 16-17 days p.c., CBA/J at 16 days p.c and C57Bl/6 at 14-15 days p.c. (Fig. 1).

The CBA/J strain drastically reduced the rearranged DNA segment at 17 days p.c., reappearing in newborn and adult thymus.

\section{Waves of gene expression}

The developing thymus of the three strains displayed three gene clusters according to their waves of expression levels
A)

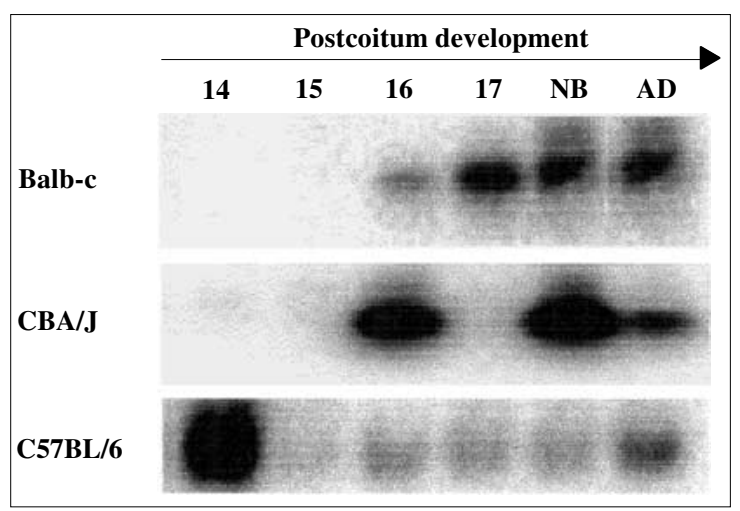

B)

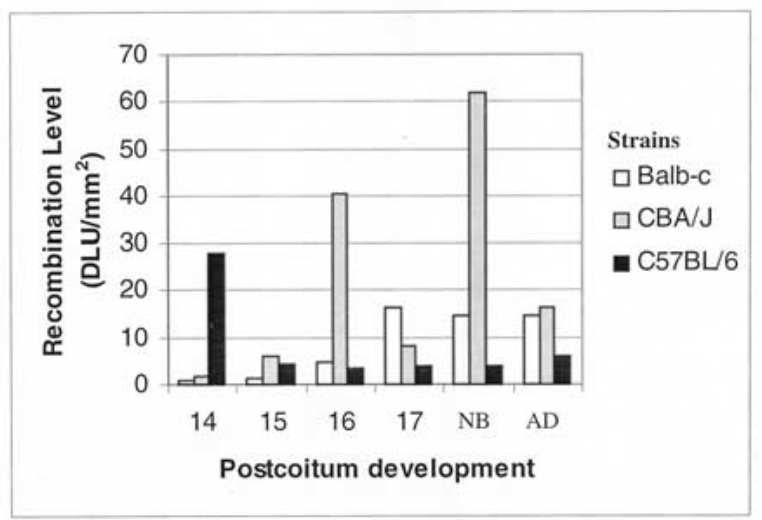

Fig. 1. V(D)J recombination between TCRV $\beta 8.1$ and D $\beta 2.1$ during thymus development investigated by PCR. (A) Southern-blot of PCR products. (B) Quantification of hybridizations using a phosphor-imager. Arbitrary values expressed in DLU (digital light units) as displayed by the OptiQuant ${ }^{\circledR}$ software. 
as organized by the Tree View software. However, the constitution of these clusters diverged among strains, i.e. each cluster harbor different genes with different expression patterns.

\section{Balb-c Strain (Fig. 2a)*}

Cluster 1 comprised the IL-4 gene which was not modulated remaining expressed at low levels during thymus development.

Cluster 2 comprised MHC-I, RAG-2, IF- $\gamma$, IL-6, MHC-II, MMTV(SW), IL-1 $\beta$, RAG-1, IL-2, IL- $1 \alpha$ and TCRV $\beta$ genes. We observed waves of transcriptional activity at 15-16 days p.c. involving MHC-I, RAG-2, IF- $\gamma$, IL-6 and MHC-II. The adult thymus overexpressed IF- $\gamma$, IL-6, MHC-II, MMTV(SW), IL-1 $\beta$, RAG- 1 and IL-2.

Cluster 3 comprised IL-3, IL-2R $\beta$, TNF- $\beta$, IL-7 and GMCSF genes which displayed a peak of expression at 14 days p.c. remaining unmodulated and at low levels during development.

Taken together, the genes of the cluster 2 were usually more transcribed at 16 days p.c. and in newborn pups and adults.

\section{CBA/J Strain (Fig. 2b)}

Cluster 1 comprised MHC-II, IL-6, MMTV(SW), IL-2R $\beta$ and IL-7 genes displaying a peak of expression in the late thymus (17 days p.c. and newborn pups).

Cluster 2 comprised IF- $\gamma$, IL- $1 \alpha$, IL-3, IL-2, MHC-I, TNF$\beta$, IL-1 $\beta$, TCRV $\beta$, RAG-2 and RAG-1 genes and showed a more equilibrated transcriptional activity, i.e. waves of upand down-regulation distributed during development.

Cluster 3 comprised IL-4 and GM-CSF genes which, in relation to the other strains, were not modulated remaining expressed at low levels during thymus development.

\section{C57Bl/6 Strain (Fig. 2c)}

Cluster 1 also comprised only the IL-4 gene which was not modulated, remaining expressed at low levels during thymus development.

Cluster 2 comprised IL-1 $\beta$, IL-3, TCRV $\beta$, MMTV(SW), IL- $1 \alpha$, RAG- 2 and TNF- $\beta$ genes. These genes were usually down-regulated except MMTV(SW) and TNF- $\beta$ which displayed two peaks of expression at 16 days p.c. and newborn pups.

\footnotetext{
*Figure 2 is available at: www.rge.fmrp.usp.br/passos/RT_PCR
}

Cluster 3 comprised RAG-1, IL-6, IL-7, MHC-I, IL-2, IL$2 \mathrm{R} \beta$, MHC-II, IF- $\gamma$ and GM-CSF genes. Taken together, the genes of the cluster 3 were more transcribed displaying a peak of expression at 17 days p.c. except GM-CSF which was overexpressed in the early thymus (14-15 days p.c.) and down-regulated later.

\section{Discussion}

Our aim was to compare the evolution of TCR V $\beta 8.1-\mathrm{D} \beta 2.1$ $\mathrm{V}(\mathrm{D}) \mathrm{J}$ rearrangements and transcription of several genes important in T-cell differentiation during the thymus ontogeny of normal inbred mouse strains. We observed that emergence of $\mathrm{V}(\mathrm{D}) \mathrm{J}$ recombination and transcription of TCR $\beta$ locus differ among these strains (Fig. 1), strongly suggesting an effect of genetic background as previously discussed $[1,2]$.

T-cell differentiation occurs within the thymus and all developmental stages are distinguishable by their expression of combination of CD cell-surface markers. The V(D)J recombination of the TCR $\alpha / \beta$ and $\gamma / \delta$ segments is a central phenomenon defining the T-cell fate, which is mediated by the recombinase complex from RAG-1 and RAG-2 genes and modulated by several other gene products $[3,4]$.

Transcriptional regulation studies have monitored expression of RAG-1, RAG-2, transcription factors and cytokine genes during T-cell development in vitro and in vivo. T-cell specific transcription factors such as TCF-1, LEF-1, Sox-4, CREB and GATA-3 modulate the expression of several other important genes such as TCRs, RAG-1, IL- 4 and CD4/CD8 $\alpha$ markers [16]. Data obtained by reverse transcription-polymerase chain reaction (RT-PCR) with total thymocytes showed that expression of RAG-1 begins at a high level and is then developmentally down-regulated, and IL-2 and IL-4 are both expressed at a low levels [17].

The mouse strains we studied displayed different expression patterns involving the 17 genes assayed (Fig. 2). These findings demonstrate that the RT-PCR method followed by hierarchical clustering can be used to visualize the effect of genetic background on the expression profiling of the thymus. Moreover, associations between the expression data can be established.

Several studies using in vitro cultures of fetal liver cells or fetal thymocytes have suggested that IL-7 signaling could specifically induce RAG-1 and RAG-2 and thus have an effect on TCR $\beta$ rearrangements. Moreover, as thymocytes differentiate further, IL-7 becomes the dominant cytokine that appears to serve as a proliferative agent before and after rearrangement, and possibly as a survival factor during rearrangement $[5,7]$.

Clustering (Fig. 2) showed that the peak of IL-7 gene expression occurred before (Balb-c and $\mathrm{C} 57 \mathrm{Bl} / 6$ ) or usually 
coincided $(\mathrm{CBA} / \mathrm{J})$ with expression of the RAG-1 and RAG2 genes.

In agreement with previous observations $[17,18]$ we observed that the overall level of RAG-2 expression was lower than that of RAG-1 in Balb-c and C57B1/6 mice, whereas the inverse situation was observed in $\mathrm{CBA} / \mathrm{J}$ mice.

Germline transcripts of TCRV $\beta$ were detected before the TCR $\beta$ locus rearrangements $[1,19-22]$ and our results with the CBA/J strain agree these observations. However, TCRV $\beta$ was one among the lesser transcribed genes.

MHC-I and MHC-II displayed different expression patterns among strains and there was a suggestion that their contribution to the termination of TCR rearrangements is unlikely [23].

The clustering of IL-1 $\alpha$, IL-1 $\beta$, IL-2, IL-3, IL-4, IL-6, IF$\gamma$ and IL-2R $\beta$ genes diverged among strains; however, we observed a common tendency of their expression after (Balbc) and before RAG-1 and RAG-2 genes (C57B1/6 and CBA/ J strains).

We were able to quantify the expression levels of all these genes implicated in T-cell proliferation, $\mathrm{V}(\mathrm{D}) \mathrm{J}$ recombination or T-cell clonal deletion, such as $\mathrm{MMTV}(\mathrm{SW})$ retroviral superantigen, during thymus ontogeny (14-17 days p.c.) in newborn pups and adults. The onset of the TCRV $\beta 8.1-D \beta 2.1$ rearrangement in fetal thymus was correlated with a previous expression of germline TCRV $\beta 8.1$ in the CBA/J strain (15-16 days p.c.). The most evident feature demonstrated was the kinetics of MMTV(SW) mRNA overexpression and parallel reduction of the TCRV $\beta 8.1-\mathrm{D} \beta 2.1$ rearrangement in the 17 days p.c. thymus DNA of the of the CBA/J strain (Fig. 1), suggesting a susceptibility of this strain to the expression of $\operatorname{MMTV}(\mathrm{SW})$ superantigen in combination with its genetic background, including $\mathrm{MHC} \mathrm{H}-2^{\mathrm{k}}$, upon reduction of T-cell clones bearing the rearranged V $\beta 8.1$ DNA segment, while coinciding with overexpression of IL-7 gene that plays a role in T-cell proliferation.

Expression of superantigen proteins from endogenous MMTV proviruses carried by mouse germline usually results in the deletion of self-reactive T-cells during negative selection in the thymus and the elimination of T-cells required for infection by specific milk-borne MMTVs [24, 25].

Our data contribute to establishing a direct correlation between the different expression profiling, including cytokines, and backgrounds of the strains with evolution of TCRV $\beta 8.1$ D $\beta 2.1$ rearrangements, of particular interest for characterization of $\mathrm{CBA} / \mathrm{J}$ mice, since the expression of these genes are not typically studied in this strain.

However, due to the complexity of this phenomenon involving the participation of a range of known and unknown genes, our model-system with inbred mouse strains open perspectives for further studies on large-scale gene expression profiling using DNA-arrays.

\section{Acknowledgements}

A.R.E., C.M.J. and R.S.C. are predoctoral fellows supported by FAPESP (00/01705-8, 96/07847-1 and 00/09994-9, respectively), C.M. is a fellow from the Ludwig Institute for Cancer Research (São Paulo) in the Human Cancer Transcript Sequencing Project. We thank the INSERM-FAPESP agreement which has permitted cooperation between the Brazilian and French groups. G.A.S.P. received grants from FAPESP (98/09789-4, 98/05584-9, 99/12135-9 and 00/12495-4).

\section{References}

1. Junta CM, Passos GAS: Emergence of TCR $\alpha / \beta \mathrm{V}(\mathrm{D}) \mathrm{J}$ recombination and transcription during ontogeny of inbred mouse strains. Mol Cell Biochem 187: 67-72, 1998

2. Macedo C, Junta CM, Passos GAS: Onset of T-cell receptor V $\beta 8.1$ and $\mathrm{D} \beta 2.1 \mathrm{~V}(\mathrm{D}) \mathrm{J}$ recombination during thymus development of inbred mouse strains. Immunol Lett 69: 371-373, 1999

3. Muegge K,Vila MP, Durum SK: Interleukin-7: A cofactor for V(D)J rearrangement of the T-cell receptor gene. Science 261: 93-95, 1993

4. Sollof RS, Wang TG, Dempsey D, Jennings SR, Wolcott RM, Chervenak $\mathrm{R}$ : Interleukin 7 induces TCR gene rearrangement in adult marrowresident murine precursor T cells. Mol Immunol 34: 453-462, 1997

5. Candeias S, Muegge K, Durum SK: IL-7 receptor and V(D)J recombination: Trophic vs. mechanistic actions. Immunity 6: 501-508, 1997

6. Haks MC, Oosterwegel MA, Blom B, Spits H, Kruisbeek AM: Cellfate decisions in early T-cell development regulation by cytokine receptors and pre-TCR. Sem Immunol 11: 23-37, 1999

7. Di Santo JP, Rodewald HR: In vivo roles of receptor tyrosine kinases and cytokine receptors in early thymocyte development. Current Opin Immunol 10: 196-207, 1998

8. Laky K, Lefrançois L, von Freeden-Jeffry U, Murray R, Puddington L: The role of IL-7 in thymic and extrathymic development of TCR gamma-delta cells. J Immunol 161: 707-713, 1998

9. Schlissel MS, Durum SD, Muegge K: The interleukin 7 receptor is required for T-cell receptor gamma locus accessibility to V(D)J recombinase. J Exp Med 191: 1045-1050, 2000

10. Weissman IL: Developmental switches in the immune system. Cell 76: 207-218, 1994

11. Mombaerts P, Iacomini J, Johnson RS, Herrup K, Tonegawa S, Papaioannou VE: RAG-1 deficient mice have no mature B and T lymphocytes. Cell 68: 869-877, 1992

12. Hempel WM, Stanhope-Baker P, Mathieu N, Huang F, Schlissel MS, Ferrier P: Enhancer control of V(D)J recombination at the TCR beta locus: Differential effects on DNA cleavage and joining. Genes Dev 12: 2305-2317, 1998

13. Eisen MB, Spellman PT, Brown PO, Botstein D: Cluster analysis and display of genome-wide expression patterns. Proc Natl Acad Sci USA 95: 14863-14868, 1998

14. Eisen M: Gene cluster treeview. Stanford University (http://genomewww.stanford.edu/serum), 2001

15. Rugh R: The Mouse: Its Reproduction and Development. Burgess, Minneapolis, 1968

16. Rothenberg EV, Telfer JC, Anderson MK: Transcriptional regulation of lymphocyte lineage commitment. BioEssays 21: 726-742, 1999

17. Wilson A, Held W, MacDonald HR: Two waves of recombinase expression in developing thymocytes. J Exp Med 179: 1335-1360, 1994 
18. Turka LA, Schatz DG, Clettinger MA, Chun JJM, Gorka C, Lee K, Mc Cormack WT, Thompson CB: Thymocyte expression of RAG-1 and RAG-2: Termination by T-cell receptor cross-linking. Science 253: 778-781, 1991

19. Mallick CA, Dudley EC, Viney JL, Owen MJ, Hayday AC: Rearrangement and diversity of T-cell receptor beta chain genes in thymocytes: A critical role for the beta chain. Cell 73: 513-519, 1993

20. Godfrey DI, Kennedy J, Mombaerts P, Tonegawa S, Zlotnik A: Onset of TCR $\beta$ gene rearrangement and role of TCR $\beta$ expression during CD3-, CD4-, CD8- thymocyte differentiation. J Immunol 152: 47834791, 1994

21. Chung S, Strominger JL: Regulation of T-cell antigen receptor (TCR) $\alpha$-chain expression by TCR $\beta$ chain transcripts. Proc Natl Acad Sci USA 92: 3712-3716, 1995

22. Guidos CJ, Williams CJ, Wu GE, Paige CJ, Danska JS: Development of CD4+CD8+ thymocytes in RAG-deficient mice through a T-cell receptor $\beta$ chain-independent pathway. J Exp Med 181: 1187-1195, 1995

23. Robey E, Fowlkes BJ: Selective events in T-cell development. Ann Rev Immunol 12: 675-705, 1994
24. Acha-Orbea H, Shakhov AN, Scarpellino L, Kolb E, Muller V, Vessazshaw A, Fuchs R, Blochlinger K, Rollini P, Billotte J, Sarafidou M, MacDonald HR, H. Diggelmann H: Clonal deletion of V-beta 14-bearing T-cells in mice transgenic for mammary tumour virus. Nature 350: 207-211, 1991

25. Barnett A, Mustafa F, Wrona TJ, Lozano M, Dudley JP: Expression of mouse mammary tumor virus superantigen mRNA in the thymus correlates with kinetics of self-reactive T-cell loss. J Virology 73: 66346645, 1999

26. Montgomery RA, Dallman MJ: Analysis of cytokine gene expression during fetal thymic ontogeny using polymerase chain reaction. J Immunol 147: 554-560, 1991

27. Hikida M, Mori M, Kawabata T, Takai T, Ohmori H: Characterization of B-cells expressing recombination activating genes in germinal centers of immunized mouse lymph nodes. J Immunol 158: 2509-2512, 1997

28. Le Bon A, Desaymard C, Papiernik M: Neonatal impaired response to viral superantigen encoded by MMTV(SW) and Mtv-7. Int Immunol 7: 1897-1903, 1995 